\title{
De rol van kennis in fysiotherapeutische diagnostiek : psychometrische en cognitief-psychologische studies
}

Citation for published version (APA):

Ronteltap, C. F. M. (1990). De rol van kennis in fysiotherapeutische diagnostiek : psychometrische en cognitief-psychologische studies. [Doctoral Thesis, Maastricht University]. Rijksuniversiteit Limburg. https://doi.org/10.26481/dis.19900921cr

Document status and date:

Published: 01/01/1990

DOI:

$10.26481 /$ dis. $19900921 \mathrm{cr}$

Document Version:

Publisher's PDF, also known as Version of record

\section{Please check the document version of this publication:}

- A submitted manuscript is the version of the article upon submission and before peer-review. There can be important differences between the submitted version and the official published version of record.

People interested in the research are advised to contact the author for the final version of the publication, or visit the DOI to the publisher's website.

- The final author version and the galley proof are versions of the publication after peer review.

- The final published version features the final layout of the paper including the volume, issue and page numbers.

Link to publication

\footnotetext{
General rights rights.

- You may freely distribute the URL identifying the publication in the public portal. please follow below link for the End User Agreement:

www.umlib.nl/taverne-license

Take down policy

If you believe that this document breaches copyright please contact us at:

repository@maastrichtuniversity.nl

providing details and we will investigate your claim.
}

Copyright and moral rights for the publications made accessible in the public portal are retained by the authors and/or other copyright owners and it is a condition of accessing publications that users recognise and abide by the legal requirements associated with these

- Users may download and print one copy of any publication from the public portal for the purpose of private study or research.

- You may not further distribute the material or use it for any profit-making activity or commercial gain

If the publication is distributed under the terms of Article $25 \mathrm{fa}$ of the Dutch Copyright Act, indicated by the "Taverne" license above, 


\section{DE ROL VAN KENNIS IN FYSIOTHERAPEUTISCHE DIAGNOSTIEK}

Psychometrische en cognitief-psychologische studies 
, 


\section{DE ROL VAN KENNIS \\ IN \\ FYSIOTHERAPEUTISCHE DIAGNOSTIEK}

Psychometrische en cognitief-psychologische studies

\section{PROEFSCHRIFT}

ter verkrijging van de graad van doctor

aan de Rijksuniversiteit Limburg te Maastricht, op gezag van de Rector Magnificus, Prof.dr. F.I.M. Bonke, volgens het besluit van het College van Dekanen, in het openbaar te verdedigen op vrijdag, 21 september 1990 om 16.00 uur

door

Cosmas Franciscus Maria Ronteltap geboren te Haarlem in 1948 
Promotor:

Beoordelingscommissie: Prof.dr. L. Boon (voorzitter) Prof.dr.ir. A. Hasman

Dr. Tj. Imbos

Dr. J.J. Peters

Prof.dr. W.H.F.W. Wijnen 
Voor Margreet, Maarten en Pieter 


\section{HOOFDSTUK 1}

De kennisafhankelijkheid van probleemoplossen

Inleiding

Diagnostiek als probleemoplossen

Het diagnostisch proces

De kennisafhankelijkheid van probleemoplossen

Onderzoek naar de rol van kennis in diagnostiek

Schets van de studies naar het verband tussen kennis en probleemoplossen in dit proefschrift

\section{HOOFDSTUK 2}

Het verband tussen kennisniveau en vaardigheid in het oplossen van fysiotherapeutische problemen

Inleiding

Studie 1: Het verband tussen kennis en probleemoplossen in het fysiotherapeutisch domein: analyse op basis van composiet-scores

Methode

Proefpersonen

Meetinstrumenten

Procedure

Analyse

Resultaten en discussie

Conclusie

\section{HOOFDSTUK 3}

Kennis als noodzakelijke conditie voor probleemoplosvaardigheid; onderzoek naar de kans op een juiste probleemoplossing bij aanwezigheid van relevante voorkennis

Inleiding

Studie 2: Het verband tussen kennis en probleemoplossen in het fysiotherapeutisch domein; analyse op item-niveau

Methode

Proefpersonen

Meetinstrumenten

Procedure

Analyse 


\section{HOOFDSTUK 4}

Activatie van kennis bij het oplossen van problemen

Inleiding

Probleemherkenning en analogie

Studie 3: Beínvloeding van probleemoplosvaardigheid door activatie van kennis; verslag van een experiment

Methode

Proefpersonen

Meetinstrumenten

Procedure

Analyse

65

Resultaten

67

Discussie

\section{HOOFDSTUK 5}

Kwalitatieve kenmerken van kennis en hun relatie met het oplossen van problemen

Inleiding

De ontwikkeling van noviet tot expert

Expertise

De interactie tussen warneming en kennis en de vorming van een probleemrepresentatie

De ontwikkeling van vakgebonden kennis tot domeinspecifieke geïntegreerde kennis

Goede en zwakke probleemoplossers: het verband tussen kennis en probleemoplossen binnen groepen van gelijk ervaringsniveau

Studie 4: Onderzoek naar het verband tussen kwalitatieve kenmerken van kennis en de juistheid van de probleemoplossing

Methode

Proefpersonen

Meetinstrumenten

Procedure

Analyse

Resultaten

Probleemrepresentatie

Kennis over aandoeningen 


\section{HOOFDSTUK 6}

De rol van kennis bij het oplossen van fysiotherapeutische problemen: implicaties voor het onderwijs

Inleiding

Probleemoploswaardigheid en individuele ontwikkeling van kennis:

discussie over de resultaten van de vier studies

Samenvatting

Summary

Literatuur

Bijlage 1

Casus schouderklacht en kennisitems

Bijlage 2

Probleemtoets en kennisitems

Curriculum Vitae 


:




\section{Voorwoord}

Ofschoon een proefschrift door één persoon wordt geschreven en verdedigd mag niet worden vergeten dat vele anderen betrokken waren bij de totstandkoming ervan. Een woord van dank aan allen die een bijdrage leverden aan het werk dat voor $\mathrm{u}$ ligt is dus op zijn plaats.

Een bijzonder woord van dank wil ik richten aan Taco Bisscheroux die ruim twee jaar als onderzoeksassistent werkzaam was in het project waarvan dit proefschrift het resultaat is. Daarin was hij verantwoordelijk voor de fysiotherapeutische inhoud van het onderzoeksmateriaal en de verwerking van gegevens. Het enthousiasme waarmee hij zijn taak uitvoerde was voor mij stimulerend. Zijn rol bleef dan ook al gauw niet beperkt tot die van uitvoerend assistent, hij was eveneens een creatieve sparringpartner. Ontegenzeggelijk is deze taakopvatting in belangrijke mate bepalend geweest voor het welslagen van de onderneming. Ik ben verheugd hem ook aan mijn zijde te weten als paranimf tijdens de openbare verdediging.

Onderwijskundigen zijn vaak creatief in het bedenken van modellen van het leerproces. Echter, de van oudsher bekende dialoog tussen meester en gezel is, zo is mij uit eigen ervaring gebleken, niet minder effectief. Het schrijven van een proefschift is namelijk meer dan het afleggen van een "proeve van bekwaamheid", het is ook een leerproces voor de promovendus zelf. Een bijzonder woord van dank ben ik dan ook verschuldigd aan mijn promotor Henk Schmidt. Van zijn ervaring en inzichten mocht ik gebruik maken door middel van vele gesprekken en uitvoerige schriftelijke commentaren met betrekking tot deelproducten. Zijn opvattingen over het verband tussen kennis en probleemoplossen, voortvloeiend uit een theorie over de ontwikkeling van expertise, zijn in dit proefschrift niet alleen in theorie aanwezig, maar kwamen eveneens tot uitdrukking in zijn wijze van begeleiden.

De vakgroep Onderwijsontwikkeling \& Onderwijsresearch in zijn geheel ben ik erkentelijk voor de ruimte die mij geboden werd om het onderzoek uit te voeren zoals ik het wilde. Onder mijn collega's uit de vakgroep dank ik met name Eugène Rameckers voor de inbreng van zijn fysiotherapeutische deskundigheid in het project. Els Boshuizen dank ik voor de wijze waarop zij mij de methode voor kwalitatieve kennisanalyse demonstreerde: haar proefschrift was voor mij in meerdere opzichten een eyeopener. Steve Foster corrigeerde de summary op voorbeeldige wijze. Maureen Machiels gaf uitstekende aanwijzingen bij het analyseren van protocollen van proefpersonen. Diana Riksen 
verrichtte de statistische analyses en maakte de brij van gegevens overzichtelijk. Bart Reuten hield mij uit de wind in het COO-project en leverde bruikbare suggesties voor het ontwerp van de kaft. Petry Thiemann maakte op voortreffelijke wijze van alle los aangeleverde teksten een geheel. Zij zorgde ervoor dat het op zijn minst optisch aan de maatstaf voldoet.

Empirisch onderzoek is alleen mogelijk bij de gratie van bereidwillige medewerking van proefpersonen. Een woord van dank ben ik dus zeer zeker verschuldigd aan de studenten van de fysiotherapie-opleidingen Heerlen, Den Haag en Deventer die ondanks de drukte in hun tentamenperiode bereid waren vele uren vrij te maken voor de deelname aan het onderzoek. In dit woord van dank wil ik ook Pieter Wolters, Edward Houtkoop en Cees Besseling betrekken die als docent van de verschillende opleidingen ervoor zorgden dat voldoende proefpersonen aanwezig waren op het moment dat de onderzoekers hun materiaall op tafel legden.

Het afronden van een proefschrift geeft voldoening. Het verheugt mij bijzonder dat Margreet er in gelijke mate blij mee is als ikzelf. Zij was de stimulans in mijn studie en was dat ook hierbij. Dit geldt eveneens voor Maarten en Pieter die zich nu vooral verheugen op het feest. Ik hoop dat ze er later met plezier op terug kijken. 


\section{De kennisafhankelijkheid van probleemoplossen}

\section{Inleiding}

In dit proefschrift worden vier studies beschreven waarin de rol van kennis bij het oplossen van diagnostische problemen is onderzocht. Het terrein dat in deze studies nader onder de loupe wordt genomen, is dat van de fysiotherapeutische diagnostiek. De diagnostiek binnen dit domein van de paramedische beroepsuitoefening is nauwelijks onderzocht, in tegenstelling tot de medische diagnostiek. Het aantal wetenschappelijke publicaties op dat laatste terrein is zeer omvangrijk. In zekere zin is dit ook een exponent van de mate van professionalisering, mede in internationaal verband, van het medische beroep. Professionalisering is ook een sociologisch verschijnsel. Kenmerken van professionalisering zijn: opleidingen en diplomering, de aanwezigheid van wetenschappelijke tijdschriften, congressen en symposia, beroepsorganisaties en wettelijke regelingen rond de beroepsuitoefening. De fysiotherapie als professionele categorie binnen het geheel van de gezondheidszorg is ontstaan vanuit de heilgymnastiek waarin de correctie van lichamelijke (houdings)afwijkingen het doel van de behandeling was. Met een toename van de groei in revalidatie-technieken in de geneeskunde, en een parallel verlopende explosieve groei van geneeskundige specialismen (onder andere de chirurgie en de neurologie), ontstonden impulsen voor de ontwikkeling van de fysiotherapie. Deze ontwikkeling mondde uit in de Wet op de Paramedische Beroepen in 1963. In het kader van deze wet kreeg de fysiotherapeut de taak om mede, en soms geheel zelfstandig, een behandelingsplan voor de patiënt vast te stellen (Derijcke, Ernst \& Vinck, 1981). Deze verantwoordelijkheid voor de keuze en uitvoering van de behandeling betekende impliciet dat de fysiotherapeut een eigen diagnostische taak kreeg ter voorbereiding op die behandeling. Sellink en Wurms (1986) 
geven het volgende voorbeeld van de beginsituatie in de fysiotherapeutische diagnostiek: "Een patiënt komt bij de fysiotherapeut met een verwijzing van de huisarts waarop staat "PHS". Deze 'medische diagnose' betekent ongeveer dat een patient een pijnlijke schouder heeft en mogelijk enige bewegingsbeperkingen. PHS kan o.a. veroorzaakt worden door een tendinitis, een calcificatie, een spierruptuur, een cervicaal probleem of een hogere spiertonus veroorzaakt door stress. Voordat een fysiotherapeut een adequate behandeling kan starten is het noodzakelijk dat hij de pathologie die het probleem veroorzaakt en de betrokken weefsels identificeert. Een fysiotherapeut kan dit probleem oplossen door een eigen onderzoek." Dit voorbeeld illustreert de praktische context van de fysiotherapeutische diagnostiek: de bevindingen van de arts zijn het startpunt van de fysiotherapeut. In de praktijk zal een arts bij een verwijzing van de patiënt naar de fysiotherapeut slechts in globale zin de (voorlopige) diagnose formuleren. Het is de taak van de fysiotherapeut deze medische gegevens te specificeren in een weefselspecifieke diagnose voor de opstelling van een plan tot behandeling van deze aangedane weefselstructuren (Smits \& van der Sijde (a); van der Sijde \& Sellink, 1983; Smits \& van der Sijde, 1984 (b)). Naast de relevante medische gegevens voor zover deze uit de verwijzing bekend zijn zal de fysiotherapeut in zijn diagnose ook aandacht besteden aan relevante sociaal maatschappelijke gegevens, zoals fysieke consequenties van beroepsuitoefening en vrijetijdsbesteding. Beide categorieën tezamen zijn de basis voor een gerichte anamnese en inspectie van de patiënt die uitmonden in een fysiotherapeutisch onderzoek. In het onderzoek van de patiënt worden gegevens verzameld met betrekking tot de actualiteit van de klacht, de lokalisatie van de klacht en de symptomatologie (Derijcke, Ernst \& Vinck, 1982).

In deze inleidende schets van de fysiotherapeutische diagnostiek ligt het accent op de cognitieve activiteiten van de fysiotherapeut en de aard van de gegevens die worden verzameld in dit diagnostisch proces. Ter nadere introductie op het object van studie, het verband tussen kennis en probleemoplossen, zal in de eerstwolgende paragrafen een beschrijving worden gegeven van de kenmerken van diagnostisch probleemoplossen en het verloop van het diagnostisch denkproces. De gegevens voor deze beschrijving worden ontleend aan onderzoek in het medisch domein. Gelet op het feit dat het medisch probleemoplossen bepaalde eigen karakteristieken bezit zal moeten worden vastgesteld of de fysiotherapeutische diagnostische activiteiten vergelijkbaar zijn met die van de arts en of de inzichten die zijn ontstaan in het onderzoek van de medische diagnostiek overdraagbaar zijn naar het fysiotherapeutische domein. Daarom zal ter illustratie een onderzoek worden besproken waarin naar de overeenkomsten werd gezocht tussen de medische en fysiotherapeutische diagnostiek. 
Het centrale thema van dit proefschrift echter is de rol die vakinhoudelijke kennis speelt bij het oplossen van diagnostische problemen. Daartoe zullen in dit hoofdstuk onderzoeksresultaten worden besproken waarbij de veronderstelde kennisafhankelijkheid van probleemoplossen die de grondslag vormt voor de studies in dit proefschrift nader wordt geintroduceerd. Hoofdstuk 1 wordt afgesloten met een bespreking van een model van informatieverwerking dat bruikbaar lijkt voor onderzoek van het diagnostisch proces en dat gebruikt zal worden om de studies die in de volgende hoofdstukken beschreven worden nader te karakteriseren.

\section{Diagnostiek als probleemoplossen}

Het stellen van een diagnose door een medicus of paramedicus is het oplossen van een intellectueel probleem. Niet het probleem van de patiënt wordt hiermee bedoeld, ofschoon de "oplossing" hiervan uiteraard de uiteindelijke doelstelling is, maar het probleem als vraagstuk van het type: Welke ziekte of aandoening is verantwoordelijk voor de bij deze patiënt waar te nemen symptomen of klachten? De beantwoording van deze vraag is in sterke mate bepalend voor de prognose van de ziekte en een eventuele keuze uit het arsenaal van beschikbare therapeutische handelingen. Diagnostiseren als mentale handeling is in hoofdzaak het classificeren van ziekten of aandoeningen met onder andere de volgende functies: analyse van de oorzaken, voorspelling van verloop en etikettering voor communicatie tussen vakgenoten (Wright en MacAdam, 1982). De diagnose-formulering is een herkenbaar tussenstation in het geheel van competent handelen. Onderzoekers en theoretici die zich in hoofdzaak bezighouden met de bestudering van diagnostische vaardigheden zijn geneigd hun onderzoeksobject te karakteriseren als het belangrijkste onderdeel van competent handelen in de medische en paramedische praktijk. Deze waardering is verdedigbaar indien de "diagnostische vaardigheden" breed gedefinieerd worden. Tot de diagnostiek kunnen vaardigheden op de volgende terreinen gerekend worden: cognitieve vaardigheden, onderzoekstechnische vaardigheden en sociale vaardigheden. De titel van deze paragraaf "diagnostiek als probleemoplossen" geeft al aan dat de diagnostiek in dit proefschrift zal worden onderzocht als "cognitieve vaardigheid". Deze beperking van het onderzoeksdomein impliceert niet dat de cognitieve vaardigheden de belangrijkste factor vormen in de diagnostiek. Evenals men competent moet zijn in het cognitief verwerken van informatie, zal men ook competent moeten zijn in het verwerven van relevante informatie. Een goed sociaal contact met de pa- 
tiënt en een in technische zin goed uitgevoerd onderzoek zijn van hetzelfde belang voor de diagnostische competentie als het goed kunnen redeneren en beslissen op basis van de verkregen informatie in gesprek met, en onderzoek van, de patiënt.

Het onderscheid dat hier wordt gemaakt tussen informatie-verwerking en informatie-verwerving geeft reeds aan dat de diagnostiek in het medisch domein gekarakteriseerd kan worden als het oplossen van problemen van een bepaald type. Het is verleidelijk om een diagnostisch probleem te vergelijken met een puzzel, maar gelet op een drietal kenmerken van diagnostiseren schiet deze vergelijking toch te kort. In de eerste plaats beschikt de probleemoplosser in een diagnostisch probleem niet over een duidelijk eindcriterium dat aangeeft of het probleem correct is opgelost. Hoogstens wellicht op langere termijn, als de klacht van de patiënt is verdwenen, krijgt een arts feedback of zijn diagnose volledig correct was. Echter, het komt ook voor dat feedback in termen van een therapie-effect niet wordt waargenomen. Bovendien resteert in objectieve zin soms de vraag of het effect kan worden toegeschreven aan de met de diagnose verbonden therapie. Een tweede verschil tussen een diagnostisch probleem en een puzzelprobleem is het reeds genoemde onderscheid tussen informatie-verwerving en informatie-verwerking. Bij een puzzel is alle informatie voor de probleemoplosser beschikbaar. Bovendien beschikt de probleemoplosser over een instructie op basis waarvan de bereikte probleemoplossing kan worden geëvalueerd. Daarentegen beschikt de probleemoplosser in de beginfase van een diagnostisch probleem slechts over een minimum aan informatie. Deze basisinformatie is in de meeste gevallen slechts een zwakke afspiegeling van de informatie waarop de uiteindelijke probleemoplossing is gebaseerd. De basisinformatie in een diagnostisch probleem - de klacht waarmee een patiënt zich meldt, of een in het oog springend symptoom - is eerder het startpunt van een redeneer- en zoekproces naar bruikbare informatie. In dit redeneer- en zoekproces is de interactie met het geheugen, het gebruik van al aanwezige voorkennis, een zeer belangrijk kenmerk. Dit kenmerk typeert het meest de aard van de problemen en hun oplossingen die in dit proefschrift het object van onderzoek zijn. Samenhangend met het kenmerk van kennisgebruik bestaat er ook een fundamenteel verschil in het probleemoplosproces tussen puzzels en diagnostische problemen. Een puzzel wordt overwegend opgelost door 'trial and error' of door toepassing van een passend algoritme (een geheel van regels dat leidt naar de goede oplossing). In een diagnostisch probleem daarentegen moet de probleemoplosser de beschikbare informatie telkens opnieuw interpreteren om tot een oplossing te komen. Hoewel ook in diagnostisch probleemoplossen algoritmen bruikbaar zullen zijn, zullen deze overschaduwd worden door heuristieken. De type- 
ring van een diagnostisch probleem aan de hand van de drie hierboven beschreven kenmerken - op-oplossingscriterium, informatie-verwerving en proceskenmerken - wordt samengevat in het onderscheid tussen "goed gedefinieerde" (puzzels) en "slecht gedefinieerde" (diagnostische) problemen (Simon, 1973; Simon, 1985).

Zoals gezegd is het gebruik van al bij de diagnosticus aanwezige kennis het meest essentiële kenmerk waarin diagnostisch probleemoplossen zich onderscheidt van andersoortig probleemoplossen. De vraag die kan wordlen gesteld is welke kennis de probleemoplosser gebruikt. Daarin wordt vaak een onderscheid aangebracht tussen domeinspecifieke (of vakinhoudelijke) kennis en algemene kennis (logica; wiskunde, etc.). Dit onderscheid wordt teruggevonden in de methoden waarmee "diagnostisch denken" onderzocht kan worden. Norman (1985) beschrijft in een methodologisch overzicht van competentie-metingen in het medisch domein twee benaderingen om het diagnostisch denken te onderzoeken: 1. De informatieverwerkings-benadering waarvan het doel is te onderzoeken hoe mensen een probleem oplossen. Probleemoplossers worden geobserveerd en eventueel verzocht hun denkproces toe te lichten. In deze benadering is de onderzoeker gericht op een beschrijving van het (menselijk) probleemoplosproces en wordt de relatie tussen proceskenmerken en de kwaliteit van de probleemoplossing onderzocht. 2. De besliskundige of wiskundige benadering waarin de analytische aspecten van het beslissingsproces onderzocht worden. In de besliskundige benadering van de diagnostiek maakt De Vries Robbé (1978) een onderscheid tussen drie processen: intuitie, herinnering en logische analyse. Intuitie ${ }^{1}$ wordt buiten het onderzoek in de besliskunde gehouden omdat het "onbegrepen" is. Dit gelldt eveneens voor het proces van herinnering (het oproepen van een eerder gezien beeld) dat wordt toebedeeld aan het onderzoeksterrein van de computerondersteunde diagnostiek. De besliskundige benadering accentueert daarentegen de logische analyse van het proces met het doel algemene en formele regels te formuleren. Een verbijzondering van deze besliskundige benadering is de Bayesiaanse benadering van de diagnostiek (Wulff, 1980) waarin statistische theorieën worden toegepast vanuit het gezichtspunt dat elke diagnose wordt gesteld op basis van een afweging van waarschijnlijkheden.

De besliskundige benadering van de diagnostiek verschilt ten opzichte van de cognitieve benadering in de accentuering van de rol die de beheersing van de domeinspecifieke kennis speelt tijdens het denkproces. In de besliskunde is de domeinspecifieke kennis één van de elementen in het

" ook wel "klinische blik" genoemd. 
denkproces. In de cognitieve benadering speelt de kennis een doorslaggevende rol in het denkproces. Zoals gezegd is de cognitieve benadering van problemoplossen gebaseerd op inzichten die zijn verkregen door observatie van probleemoplossers. Voor een nadere introductie op ons onderzoeksterrein geven wij daarom eerst een, wat naturalistische, beschrijving van dit denkproces in de diagnostiek.

\section{Het diagnostisch proces}

De hiervolgende beschrijving van het diagnostisch denkproces wordt in overwegende mate ontleend aan het werk van Barrows en Tamblyn (1980).

Diagnostiek wordt soms eerder geplaatst in de categorie "kunst" dan "kunde". Daarmee wordt bedoeld te zeggen dat intuitie een sterke rol speelt en dat bekwaamheid eerder het product is van langdurige ervaring dan van een doelgericht leerproces. Intuitief handelen is voornamelijk onbewust handelen. Het is gedrag dat zich onttrekt aan de waameming door anderen of door de persoon zelf. Niettemin valt, volgens Barrows en Tamblyn, door middel van systematische observatie bijvoorbeeld van het handelen van artsen in gestandaardiseerde contacten met simulatiepatiënten, toch wel een beeld te vormen van belangrijke elementen van het proces. Observaties van dit type brachten Barrows en Tamblyn ertoe het geheel van diagnostisch handelen nader te differentiëren in verschillende gedragingen die elkaar opvolgen in het contact tussen patiënt en arts. De volgende stappen worden door deze auteurs onderscheiden: 1. Informatie-waarneming en interpretatie. Het begin van het diagnostisch proces wordt gekenmerkt door de waarneming van meer of minder gestructureerde informatie: de klacht, het gedrag en uiterlijk van de patiënt, de inhoud van een eventuele verwijzing, etc. Snel, en vaak niet bewust, wordt uit deze informatie een keuze gemakt die wordt samengevoegd tot een "initieel concept" van het probleem; een eerste interpretatie. Ervaring speelt in deze fase een belangrijke rol. 2 . Hypothesevorming. De initiele conceptualisatie van het probleem gaat vrijwel direct samen met het denken aan een verklaring voor het probleem. Beter gezegd verklaringen omdat uit observaties bleek dat meestal meer dan én hypothese wordt gegenereerd. Verschillende hypothesen behoeden de arts voor premature, en wellicht onjuiste of onvolledige, beslissingen. Ook in deze fase speelt de ervaring een belangrijke rol en is men zich vaak niet bewust van de gegenereerde hypothesen. Wanneer artsen bijvoorbeeld achteraf met het eigen gedrag geconfronteerd werden leverde dat vaak het inzicht op dat ogenschijnlijk ongestructureerde vragen aan een patiënt 
konden worden herleid tot een beperkt aantal hypothesen. De hypothesen die in deze fase gegenereerd worden, kunnen verschillen in de mate van specificiteit waarmee ze het probleem verklaren. 3. Informatie-perwerving in deze fase worden de hypothesen geconcretiseerd en geverifieerd. De uiterlijk waarneembare handelingen binnen deze fase vallen binnen twee categorieèn: anamnese en onderzoek. De vragen die worden gesteld in de anamnese en het lichamelijk of laboratoriumonderzoek dat wordt uitgevoerd staan onder invloed van de in fase 2 gegenereerde hypothesen. De informatie die men verzamelt wordt eveneens kritisch geëvalueerd binnen het raamwerk van die hypothesen. Het kiezen en uitvoeren van handelingen en het interpreteren van de ingewonnen informatie zijn de hoofdkenmerken van dit deductieve proces. Routine- of standaardmatig handelen zonder hypothese is slechts aan de orde indien de verkregen informatie niet voldoet aan de eerder gestelde verwachtingen of indien de noodzaak wordt gevoeld tot bijstelling van oude of het stellen van nieuwe hypothesen. 4. Probleemformulering. De hoeveelheid informatie die wordt verkregen is meestal groter dam het menselijk korte termijn geheugen kan bevatten. Daarom wordt alle informatie gesynthetiseerd tot hanteerbare eenheden. Ook dit proces voltrekt zich grotendeels onbewust. De probleemgeoriënteerdheid van alle handelingen in het diagnostisch proces komt tot uitdrukking in de synthese van de informatie tot één samenhangende probleemformulering. Barrows en Tamblyn (1980) zijn van mening dat de mate van bekwaamheid in het synthetiseren van informatie een belangrijk verschil is tussen ervaren en minder ervaren artsen. Indien men bijvoorbeeld studenten vraagt een samenvatting te geven van een patiëntprobleem zal blijken dat in veel gevallen een scherp afgebakend beeld en het verband tussen de gegevens ontbreekt. 5 . Diagnostische beslissing. Het eindpunt van het diagnostisch proces is de beslissing dat alle relevante informatie bekend is, om vervolgens beslissingen te kunnen nemen over het beleid en de therapie.

Uit de geordende beschrijving van het diagnostisch proces in een aantal fasen, van initieel concept tot diagnose, zou kunnen worden afgeleid dat het diagnostiseren een lineair verlopend proces is. Dit is mogelijk maar niet noodzakelijk. Afhankelijk van het probleem in kwestie en samenhangend met de kennis en ervaring van de arts kan er ook sprake zijn van een cyclische herhaling van eerder afgesloten fasen.

De beschrijving van het diagnostisch proces wordt ontleend aan observaties van artsen in de praktijk. Kent de fysiotherapeutische diagnostiek een gelijk proces van initieel concept tot diagnostische beslissing? Of anders geformuleerd: heeft de fysiotherapeutische diagnostiek ook een hypothetico-deductief karakter? Payton (1985) toetste het model van Barrows en Tamblyn 
door de beginfase van een fysiotherapeutisch onderzoek op band vast te leggen en deze met de betrokken fysiotherapeuten na afloop van het patient-contact te analyseren. Ook deze gesprekken over de bandopnamen werden geregistreerd voor latere analyses. De resultaten van deze studie toonden aan dat hetzelfde denkproces herkenbaar is in de fysiotherapie. Ook fysiotherapeuten genereren in een zeer vroege fase van het contact met de patiënt een aantal hypothesen die vervolgens systematisch worden onderzocht. De inhoud van de medische verwijzing heeft slechts een beperkte rol in de vorming van het initieel concept. In de beginfase van het patiëntcontact wordt doelgericht de verwijzing, de klacht van de patiënt en de gegevens uit een globale visuele inspectie geïntegreerd tot één initieel concept, dat de basis vormt voor de hypothesen. Het fysiotherapeutisch onderzoek wordt geconcretiseerd in een pathologische, pathofysiologische of pathokinesiologische probleembeschrijving die aansluit bij de behandelingsmethodiek van de fysiotherapeut. Payton (1985, p. 927) trekt de volgende conclusie na de vergelijking van het diagnostisch proces tussen arts en fysiotherapeut: "Terminology and content may be different, but the process is essentially the same; that is, the physician establishes a differential diagnosis without restriction, and the physical therapist establishes a problemlist within a limited area of competence". Niet geheel onbelangrijk in dit verband is het feit dat binnen de onderzochte groep fysiotherapeuten een ruime spreiding aanwezig was ten aanzien van de vertegenwoordigde specialismen (orthopedie, neurologie, etc.) en ten aanzien van de mate van klinische ervaring (5-17 jaar). $\mathrm{Er}$ is dus kennelijk sprake van een algemeen proces.

Samenvattend: in het voorgaande werd het diagnostiseren in het medisch en paramedisch domein gekarakteriseerd als het oplossen van problemen. Probleemoplossen als mentale handeling wordt gerekend tot het terrein van de cognitieve vaardigheden. Het type problemen dat kenmerkend is voor de diagnostiek werd aangeduid als "slecht gedefinieerde" problemen: de informatie die nodig is om het probleem correct op te lossen zal in het probleemoplosproces moeten worden verworven. Deze informatieverwerving en -interpretatie is doelgericht en verloopt via het genereren van hypothesen die vervolgens getoetst worden. Eindpunt van het diagnostisch proces is het nemen van een beslissing op basis van de door de probleemoplosser toegekende betekenis aan de verkregen informatie. Dit doelgerichte aspect in het diagnostisch proces dat tot uiting komt in het toewerken naar een beslissing op basis van de verkregen informatie wordt weergegeven in Figuur 1. 
Figuar 1: Stroomdiagram van het diagnostisch proces (Barrows \& Tamblyn, 1980)

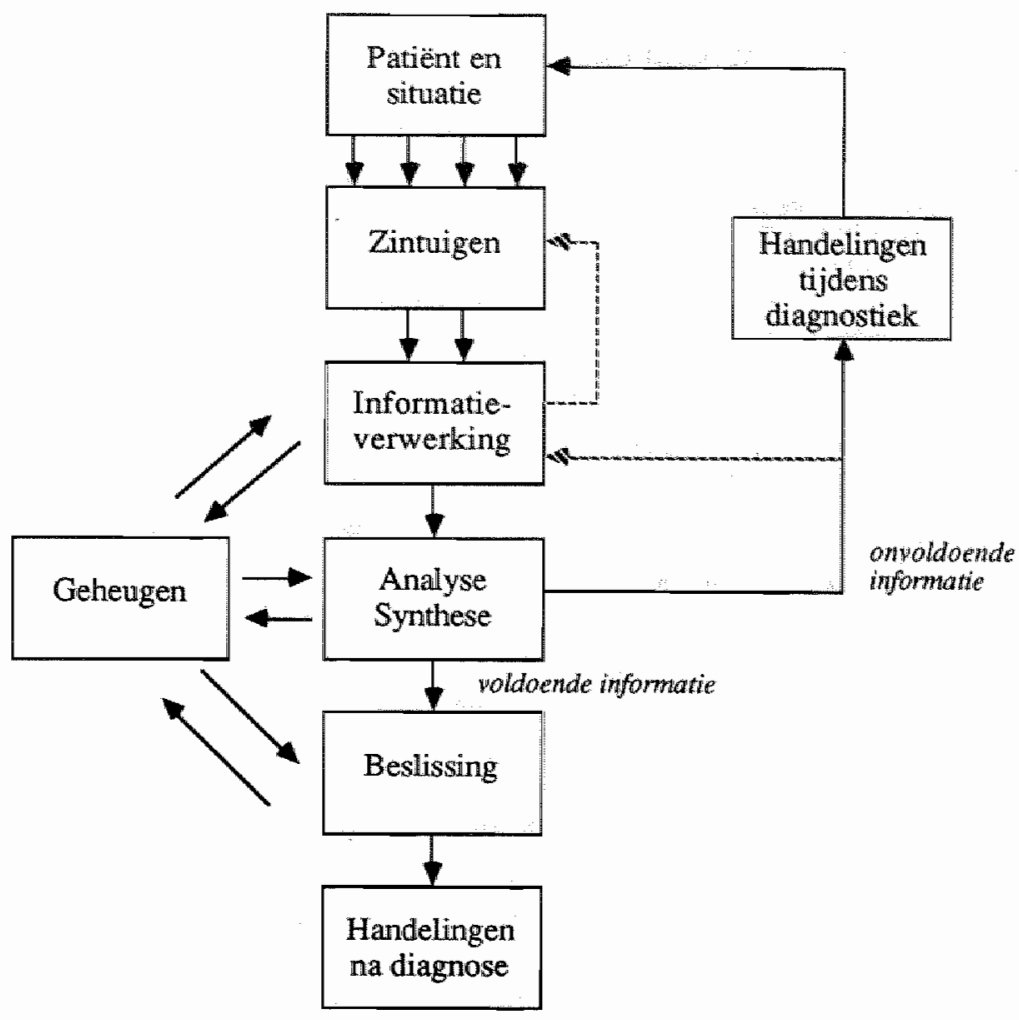

In dit stroomdiagram van het cognitief proces wordt duidelijk dat het geheugen van de probleemoplosser als opslagmedium van relevante kennis en ervaringen van grote betekenis is. De primaire informatieverwerking na de eerste waarnemingen en de synthese van de informatie wordt gestuurd door de kennis en ervaring van de probleemoplosser. Eveneens is van belang dat in dit model tot uitdrukking komt dat het geheugen wordt verrijkt met de resultaten van elke probleemoplossing. In de volgende paragraaf zal nader worden ingegaan op de aard van de kennis die wordt gebruikt in het diagnostisch proces. 


\section{De kennisafhankelijkheid van probleemoplossen}

In globale zin kan de kennis die wordt gebruikt in het diagnostisch proces nader worden onderscheiden in twee categorieën: 1 . strategische of methodische kennis, en 2. (vak)inhoudelijke kennis. Welke kennis tot beide afzonderlijke categorieén worden gerekend kan het beste geillustreerd worden aan de hand van een concreet voorbeeld. In de eerder gegeven beschrijving van het diagnostisch proces werd dit proces getypeerd als hypothetisch-deductief. Hypothesen worden gegenereerd welke via gericht onderzoek worden getoetst. Daarmee onderscheidt zich diagnostisch probleemoplossen van andersoortig probleemoplossen. De basis voor de hypothesen is het initieel concept van de patiënt: de bundeling en interpretatie van de eerst waargenomen informatie. Barrows en Tamblyn (1980) maakten bij deze fasen conceptrorming en hypothesevorming - duidelijk dat de probleemoplosser zich vaak niet bewust is van deze handelingen. Dit betekent dus dat er op twee manieren fouten kunnen worden gemaakt in de diagnostiek die herleidbaar zijn tot fouten in de beginfase. In de eerste plaats is de kans aanwezig dat vroegtijdig in het diagnostisch proces informatie wordt "gemist" die vanwege het deductieve karakter van het denkproces waarschijnlijk ook niet meer aan de orde komt. Tenzij men uiteraard vastloopt en opnieuw informatie gaat zoeken en interpreteren, maar we zagen reeds dat de kans hierop gering is omdat een diagnostisch probleem een slecht gedefinieerd probleem is met als kenmerk dat duidelijke criteria ontbreken op basis waarvan de probleemoplosser zelf kan beoordelen of de juiste oplossing gevonden is. Hierin besloten ligt de tweede kans op fouten: de vooringenomenheid tengevolge van een premature hypothese kan aanleiding geven tot onjuiste interpretaties. Van Rijsbergen, Stam, Vrijman en Zalmstra (1987, pag. 148) geven hiervan een concreet voorbeeld uit de fysiotherapeutische diagnostiek: "Indien men bijvoorbeeld bij een patiënt de hypothese intervertebrale instabiliteit heeft gesteld, zal men drukpijnlijkheid van de desbetreffende wervels verwachten. Op het moment dat de patiënt bij het testen hiervan inderdaad pijn aangeeft, zal men geneigd zijn de pijn als zodanig uit te leggen, terwijl de werkelijke oorzaak misschien een pijnlijke handvatting is." Kortom, hier is sprake van een interpretatie-fout omdat de informatie werd geìnterpreteerd vanuit een "foute" hypothese. Een belangrijk feit: de kans op een foute oplossing is reeds in een pril stadium van het denkproces aanwezig. Deze kans wordt alleen groter indien, zoals in het voorbeeld weergegeven, niet wordt ontdekt dat de informatie verkeerd wordt geïnterpreteerd. Het voorbeeld is wellicht wat overtrokken omdat in de praktijk de bevestiging van een bepaald beeld zelden is gebaseerd op 
éen bevinding. Echter Van Rijsbergen et al. (1987) waarschuwen voor onterechte enkelvoudige conclusies bij gecombineerde klachtenpatronen waarin sprake kan zijn van meerdere oorzaken. Een diagnose is dus meestal niet "goed" of "fout" maar kan variëren in gradaties van compleetheid. De consequenties die Van Rijsbergen et al. (1987) uit het gegeven voorbeeld trekken worden verwerkt in de beschrijving van een "systematisch-hypothetische" methode. Dit is een methode die de eigenschappen combineert van twee andere methoden: de "verzamel-methode" en de "intuitieve" methode. Onder de verzamel-methode verstaat men een inductief proces: het afnemen van zoveel mogelijk standaard-onderzoeken om pas in de slotfase, na raadpleging van alle informatie, conclusies te trekken. Onder de intuitieve methode verstaat men het eerder hier beschreven hypothetisch-deductief proces. De combinatie van deze twee processen tot éen systematisch-hypothetische methode verschuift de hypothese-vorming in de tijd tot dat een bepaalde hoeveelheid basis-informatie beschikbaar is. De dan eenmaal gestelde hypothesen moeten vervolgens niet serieel maar parallel worden getoetst in het fysiotherapeutisch onderzoek. De diagnostische beslissing is het resultaat van de afweging van pro's en contra's voor elke hypothese afzonderlijk. Daarbij worden de onderzochte hypothesen gerangordend naar hun mate van waarschijnlijkheid. Van Rijsbergen et al. (1987) besluiten hun methodiek-beschrijving met de opmerking dat de fysiotherapeut zich bewust moet zijn van de gehanteerde methode en wijzen de opleidingen erop dat zij in het trainen van verschillende methoden daarvoor de basis kunnen leggen. Hoewel niet expliciet uitgesproken, mag toch worden verondersteld dat de bedoelingen van Van Rijsbergen et al. verder reiken dan alleen een bewustwording van de eigen werkwijze in de diagnostiek. De argumentatie ten gunste van de gecombineerde methode wordt immers ontleend aan kritiekpunten op de beide methoden afzonderlijk. Ongetwijfeld zijn de auteurs derhalve van mening dat hun methode zal bijdragen tot een betere diagnostiek. Of dit ook werkelijk het geval is werd niet onderzocht. Echter " indien dit wel onderzocht zou worden, door bijvoorbeeld studenten te trainen in de uitvoering van deze methodiek en de effecten hiervan te bepalen, is de kans niet denkbeeldig dat deze effecten kleiner zijn dan verwacht. De onderkenning, zoals weergegeven in het hierboven geciteerde voorbeeld, dat enkelvoudige conclusies onvolledig zijn, indien er sprake kan zijn van een gecombineerd klachtenpatroon van de patiënt, is slechts mogelijk indien de probleemoplosser zelf over kennis beschikt met betrekking tot de mogelijke aanwezigheid van meerdere oorzaken van de klacht. Het succes van een methode die gericht is op een systematische hypothese-formulering blijft, ondanks de aanwezige kennis over de methodiek zelf, afhankelijk van de inhoud van de gestelde hypothesen (Ronteltap, Bisscheroux en Rameckers, 
1988). We stuiten hier op de kem van een didactisch probleem. Terecht bepleiten Van Rijsbergen et al. (1987) de aandacht voor de diagnostiek in de opleiding. De vraag is echter of de studenten met betrekking tot hun vakinhoudelijke kennis in voldoende mate zijn uitgerust om de bepleite methode te kunnen hanteren. In de volgende paragraaf zullen enkele studies worden besproken die deze stellingname ondersteunen. Deze studies waren gericht op de meting van de verandering in probleemoplosmethoden tijdens de opleiding, effecten van methodiek-training op probleemoplosvaardigheid en consistentie in de uitvoering van probleemoplosmethoden.

\section{Onderzoek naar de rol van kennis in diagnostiek}

Neufeld, Norman, Feightner en Barrows (1981) onderzochten de verbetering van de probleemoplosvaardigheid onder medische studenten. Zij vergeleken daarnaast hun gegevens met die van een studie, met dezelfde opzet, onder ervaren artsen. Langs twee wegen werden de gegevens van de studenten verkregen: 1. Cross-sectioneel door uit elke jaargroep van studenten (in totaal drie jaargroepen) een steekproef te trekken en 2. Longitudinaal door een geselecteerde groep telkens na één jaar onderwijs te toetsen ${ }^{2}$. Alle proefpersonen onderzochten één simulatie-patiënt en legden hun bevindingen vast in een medisch dossier. Het onderzoek van de patiënt werd op band vastgelegd. Daarna volgde een gesprek met een observator over de video-opname. Ook de inhoud van deze gesprekken werd vastgelegd in een protocol voor nadere analyses. Ten aanzien van nagenoeg alle procesvariabelen bestond er geen significant verband met het opleidingsniveau. Deze procesvariabelen waren o.a.: de tijdsduur van het patiëntcontact, het aantal gestelde anamnesevragen, het aantal handelingen bij het lichamelijk onderzoek, de tijdsduur voorafgaande aan de formulering van de eerste hypothese, het aantal gestelde hypothesen, etc. Uit de analyses bleek dat de studenten uit de verschillende jaargroepen onderling niet fundamenteel verschillen in de wijze waarop de gegevens in de patiënt-simulatie worden verkregen voor de bepaling van de diagnose. Kortom, de structuur van het diagnostisch proces (vroege hypotheseformulering en daarop gebaseerd onderzoek) veranderde niet fundamenteel onder invloed van het onderwijs. Bovendien bestond er geen verschil in de structuur van het denkproces tussen de medische studenten en de afgestudeerde artsen. Ten aanzien van één varia-

${ }^{2}$ Er bestond geen verschil in de resultaten tussen de cross-sectionele en longitudinale studie. 
bele bestond er in de studentenpopulatie wel een verband met het opleidingsniveau: de hypothese-score. In deze score wordt de kwaliteit (inhoud en specificiteit) van de hypothese gewogen op basis van de hypothesen van de artsen-referentiegroep. Het bleek dat studenten gedurende hun opleiding in toenemende mate betere hypothesen formuleren. Gelet op het feit dat niet de probleemoplosmethode als zodanig veranderde maar wel de inhoud van de methode in kwaliteit toenam, betekent dit dat de toename van domeinspecifieke kennis een belangrijke factor moet zijn.

Tot soortgelijke conclusies komen De Jong en Ferguson-Hessler (1983, 1984) na een experiment in het natuurkundig domein waarin de kennis over probleemoplosmethoden werd geisoleerd van de vakinhoudelijke kennis. Deze strategische kennis werd afzonderlijk aangeboden en getraind. Twee effecten werden gemeten: veranderingen in het probleemoplosproces conform de geïnstrueerde strategie (door middel van voortoetsing en natoetsing) en de samenhang tussen het probleemoplosproces en het probleemoplosresultaat. Tien eerstejaars studenten electrotechniek - de experimentele groep - ontvingen in een reguliere cursus extra instructie in een strategie voor probleemoplossen. Het probleemoplosproces en de oplossingen van deze experimentele groep werden vergeleken met die van een controlegroep $(n=6)$ die alleen de reguliere cursus volgde. In de instructie-strategie werden de studenten getraind de probleemopgave gefaseerd (in deelproblemen) op te lossen. In deze "ideale oplossingsweg" werd bij elke afzonderlijke fase aangegeven welke informatie daarin moest worden verwerkt. Elke fase bevatte bovendien een controle of deze juist was uitgevoerd. Samengevat, de studenten werden getraind in de toepassing van een methode die bij correcte uitvoering een hoge kans op een goed resultaat had. De resultaten van dit experiment waren ontnuchterend: het percentage proefpersonen uit de experimentele groep dat conform de geïnstrueerde strategie de problemen oploste was in voor- en nameting gelijk (50\%). Eveneens bleek dat het bereiken van de goede oplossing niet afhankelijk was van de gehanteerde strategie (bij natuurkundige problemen). Analyse van de gemaakte fouten (op basis van protocollen) toonde namelijk aan dat het bereiken van een foute probleemoplossing afhing van het al dan niet voorkomen van vakinhoudelijke fouten en omissies, of van rekenfouten.

De conclusie die uit beide hier besproken studies kan worden getrokken is de volgende: de toename van vakinhoudelijke kennis is een belangrijker factor in de toename van de probleemoplosvaardigheid dan het beter kunnen toepassen van systematische methoden. In het medisch domein (Neufeld et al., 1981) is er nauwelijks sprake van een verandering in methodiek gedurende de opleiding hoewel de studenten betere hypotheses gaan genereren. Daarnaast werd een studie besproken uit het natuurkundig 
domein waarin kennelijk betere oplosmethoden gehanteerd kunnen worden dan de door de studenten spontaan toegepaste methoden. Echter hierin bleek dat de geleerde methode niet wordt overgenomen. Werd de geleerde methode wel toegepast, dan bleken de toch voorkomende fouten verklaard te kunnen worden uit tekortkomingen in de vakinhoudelijke kennis.

De gegevens uit de studie van Neufeld et al. (1981) blijven niet beperkt tot de probleemoplosmethode. De onderzoekers verrichtten ook metingen over het resultaat van het probleemoplosproces. Daarbij werden de volgende variabelen onderscheiden: een diagnose-score, een score voor het medisch belleid en een score voor de voorgestelde therapie. Tussen deze variabelen en het onderwijsniveau bestond wel een consistent verband: onder toename van de onderwijsduur werden de diagnoses accurater. Ook het medisch beleid en de voorgestelde therapie namen toe in kwaliteit. In een regressieanalyse werd het verband onderzocht tussen de procesvariabelen als onafhankelijke variabelen en de diagnose-, beleids- en therapie-scores. Daaruit bleek dat alleen de hypothese-score een significante bijdrage leverde aan de regressie. De slotconclusie van deze studie is dat het onderwijs niet primair de aandacht moet richten op het probleemoplosproces (bijvoorbeeld het hypothetiseren op zichzelf) omdat dit gedragsaspect nauwelijks verandert in de loop van de studie en in essentie al aanwezig is in de beginfase van de studie. Daarentegen moet wel primaire aandacht worden besteed aan die gedragsaspecten die wèl onderhevig zijn aan veranderingen en die de kwallteit van de hypothese-formulering bepalen: kennis en ervaring. In termen van het reeds besproken onderscheid in de aard van de probleemrelevante kennis legt deze studie dus het accent op (vak)inhoudelijke kennis boven methodische kennis.

In het Medical Inquiry Project (Elstein, Shulman en Sprafka, 1978) werd ook het verband onderzocht tussen de diagnostische accuraatheid en kenmerken van het diagnostisch proces. Een geselecteerde groep artsen werd een beperkt aantal probleemsituaties gepresenteerd in de vorm van gesimuleerde patiènt-contacten en papieren simulaties. In de eerste plaats werd de consistentie in het diagnostisch proces gemeten door middel van berekening van correlaties tussen de waarden van de procesvariabelen over drie verschillende metingen. De resultaten van deze analyse zijn opgenomen in Tabel 1 .

De zonder uitzondering lage correlaties tussen de procesvariabelen over verschillende simulaties geeft aan dat er geen sprake is van consistent gedrag van de probleemoplossers. Otschoon alle probleemoplossers het onderzoek van de patiënt uitvoerden op basis van specifieke hypothesen (dus in 
Tabel 1: Correlaties tussen procesvariabelen over dre casus (Elstein, Shulman \& Sprafka, 1978, pag. 85)

\section{Procesvariabelen}

$r^{1-x^{2}} \quad r^{2-3} \quad r^{2-3}$

- totale tijdsdurur

- moment van eerste hypothese

- aantal actieve hypothesen na $25 \%$ van de totale tijdsduur

- aantal actieve hypothesen na 50\% van de totale tijdsduur

- totaal aantal gegenereerde hypothesen

- aantal onderzochte hypothesen

- waargenomen probleeminformatie (relatief)

- waargenomen probleeminformatie (absoluut)

- waargenomen kritische probleeminformatie (relatief)

- waargenomen kritische probleeminformatie (absoluut)

- efficiency

- juistheid van interpretatie
19

\section{.35}

.19

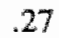

.35

.03

.02

$-.02$

.07

.05

$-.22$

$-.23$

.31

$-.26$

$-.03$

.13

.33

.39

.06

.20

.27

$-.18$

.17

$-.09$

27

$-.07$

.15

.19

$-.12$

.36

$-.37$

grote lijnen dezelfde methode hanteerden in verschillende situaties) laat deze gedetailleerde analyse en vergelijking van de afzonderlijke procesmetingen zien dat in wisselende situaties binnen personen gedragsverschillen optreden. Een globale indicatie hiervan is de snelheid waarmee het probleem wordt opgelost. Immers, een belangrijk kenmerk van thet diagnostisch proces is het genereren van hypothesen in een vroege fase van het consult. Slaagt men hier niet in, dan geeft de basisinformatie kennelijk onvoldoende houvast om doelgericht en efficiënt toe te werken naar een diagnose. In de praktijk zal dan worden overgegaan op een systematische en routinematige wijze van informatie-verzameling ter voorbereiding op de vorming van een initieel concept. Alle informatie die wordt verkregen, al of niet doelgericht verzameld, moet worden geinterpreteerd door de probleemoplosser. Dit impliceert dat aan de informatie door de probleemoplosser betekenis wordt toegekend. Anders gezegd, de domeinspecifieke kennis van de probleemoplosser speelt een cruciale rol. De inwinning van kritische informatie en de juistheid van interpretatie zijn dus belangrijke procesvariabelen die direct beinvloed worden door de kennis van de probleemoplosser. Voor alle procesvariabelen werd in een variantieanalyse getoetst of er een verband bestaat tussen proceskenmerken en diagnostische accuraatheid. Afzonderlijke toetsingen per simulatie (drie casus) hadden als resultaat dat geen enkele 
procesvariabele een significant verband vertoonde met de juistheid wan de diagnose. Hergroepering van de probleemoplossers (accuraat $=3$ goede diagnoses, niet-accuraat $=1$ of 2 goede diagnoses) en herhaling van de variantie-analyse over het gemiddelde van drie simulaties leverde wel twee significante verbanden op. Niet significant waren het tijdstip waarop de eerste hypothese werd gegenereerd, het totaal aantal gegenereerde hypothesen en de efficiency van het diagnostisch proces. Well significant waren het percentage "waargenomen-informatie" $(\mathrm{F}=4.64, \mathrm{p}<.05)^{3}$ en de juistheid van interpretatie $(F=4.44, p<.05)$. Aangezien beide variabelen onderling onafhankelijk waren binnen de afzonderlijke simulaties is er geen sprake van een artefact. Elstein et al. (1978) komen op basis van deze analyses tot de conclusie dat er twee afzonderlijke elementen herkenbaar zijn in het model van het diagnostisch proces die bijdragen aan de kwaliteit van de diagnose als uitkomst van dit proces: informatie-verwerving en informatie-interpretatie.

Dezelfde twee elementen komen ook voor in het onderzoek van Johnson, Duran, Hassebrock, Moller, Prietula, Feltovich en Swanson (1981) waarin een computersimulatie (DIAGNOSER) werd ontwikkeld om voorspellingen te kunnen doen over het gedrag van menselijke probleemoplossers. Eerst werd een programma ontwikkeld waarin de kennis werd opgenomen van enkele medische experts. Het simulatie-model werd gevalideerd door het redeneerproces binmen de simulatie kwalitatief te vergelijken met dat van een groep artsen die verschilden in ervaring. Het resultaat van deze vergelijking was dat de inhoud van het diagnostisch denkproces van de meer ervaren artsen meer overeenstemde met dat van de computersimulatie. Daarmee kon de simulatie gehanteerd worden als norm voor de beoordeling van menselijk probleemoplossen. Een analyse van het model dat ten grondslag ligt aan de simulatie leverde twee condities op waaronder het redeneerproces kan leiden tot fouten. Het eerste type fout dat gemaakt kan worden is, zoals de onderzoekers het uitdrukken, "simply not to think of the correct answer". Het tweede type fout is het gebrek aan correcte evaluatie van de gegevens in relatie tot de onderzoekshypothesen. Het sluitstuk van deze studie vormde een observatie van het diagnostisch proces van een nieuwe groep artsen. Beide condities bleken in de protocol-analyses aanwezig te zijn indien fouten werden gemaakt in het probleemoplossen. Johnson et al. (1981) verklaren beide foutencategorieën uit onvoldoende precisie in de kennis met betrekking tot de ziekte die gediagnostiseerd had moeten worden.

${ }^{3}$ Elke casus bevatte een optimum aan diagnostisch relevante informatie. 


\section{Schets van de studies naar het verband tussen kennis en probleemoplossen in dit proefschrift}

In dit hoofdstuk werden de grondlijnen van het diagnostisch probleemoplossen beschreven. Observaties van de beroepsuitoefening onder artsen en fysiotherapeuten brachten aan het licht dat het mogelijk is het diagnostisch proces te differentiëren in een beperkt aantal opeenvolgende fasen, mogelijk lineair opeenvolgend maar mogelijk ook cyclisch. Dit proces wordt afgesloten met het nemen van een diagnostische beslissing. Deze beslissing wordt genomen op basis van de interpretatie van gegevens die de probleemoplosser zelf verzamelt. Deze gegevens-verzameling is doelgericht en wordt gestuurd door ideeën die het probleem verklaren: de hypothesen. Dit betekent dat met name aan het begin- en eindpunt van het denkproces de kennis van de probleemoplosser een cruciale rol speelt. In het begin door de basisinformatie in te kaderen tot "gekende" grootheden en deze om te zetten in hypothesen. Aan het eind door de verzamelde informatie te interpreteren vanuit de gegenereerde hypothesen. Deze dominantie van kennis in de accuraatheid van diagnostisch probleemoplossen werd aangeduid als de kennisafhankelijkheid van probleemoplossen. Echter, kennis als onderdeel van competentie is een ruim begrip. Het is uiteraard mogelijk een onderscheid te maken tussen methodische kennis en inhoudelijke kennis. Onder methodische kennis wordt alle - metacognitieve - kennis verstaan over de wijze waarop het probleemoplosproces optimaal verloopt. Ook inhoudelijke kennis is een ruim begrip dat nader kan worden ontleed. Daarvan wordt echter op dit moment afgezien aangezien de beschrijvingen van de nu volgende studies daarvoor een beter kader bieden.

In alle studies die in dit proefschrift besproken zullen worden is de primaire invloed van de inhoudelijke kennis op het resultaat van het probleemoplosproces het uitgangspunt. De argumentatie hiervoor wordt ontleend aan de resultaten van de hiervoor besproken studies die wij hier nogmaals samenvatten. In de studie van de Jong en Ferguson-Hessler (1983, 1984) zagen we dat er geen overdraagbaar effect optreedt, in termen van het beter oplossen van nieuwe problemen, indien studenten extra instructie krijgen die betrekking heeft op het volgen van een optimaal werkzame methode. Foutenanalyses toonden aan dat de fouten (onafhankelijk van de methode) konden worden herleid tot omissies en misconcepties in vakinhoudelijke kennis die had moeten worden toegepast in de opgaven. In de studie van Neufeld et al. (1981) werd geconstateerd dat medische studenten wel beter gaan diagnostiseren gedurende hun opleiding maar geen veranderingen laten zien in de wijze waarop ze problemen aanpakken. 
Duidelijk werd dat bij diagnostisch probleemoplossen, kennelijk spontaan, een methode wordt toegepast die onafhankelijk is van de ervaring in het betrokken domein. Analyse van de samenhang tussen proceskenmerken en de diagnostische accuraatheid toonde aan dat alleen de inhoud en specificiteit van de onderzoekshypothesen een verband hadden met het bereiken van een goede diagnose. Een toename van de probleemoplosvaardigheid, onder toename van de ervaring, zou kunnen impliceren dat op een zeker moment in de ontwikkeling een stadium wordt bereikt waarop men lemand zou kunnen kwalificeren als een "goed probleemoplosser". Of anders, op een zeker moment is er sprake van een niveau waarop de kans groot is dat elk willekeurig domeinspecifiek probleem goed kan worden opgelost. Het blijkt echter dat de grenzen toch scherper kunnen worden getrokken. Elstein et al. (1978) onderzochten de consistentie in het probleemoplosgedrag van artsen. Lage correlaties tussen procesvariabelen over verschillende probleemsituaties toonden aan dat er sprake was van variabel gedrag. Geen enkele procesvariabele afzonderlijk toonde bovendien een significant verband met de diagnostische accuraatheid. Bijvoorbeeld, dus niet het tijdstip waarop de hypothese werd geformuleerd is van belang, maar de kwaliteit van de geformuleerde hypothese. Indien men de basisinformatie niet direct kan interpreteren in termen van een mogelijke hypothese en vervolgens besluit tot een routinematige handeling kan men nog wel een goede oplossing bereiken. Maar alleen als men op een zeker moment tot de goede hypothese komt en de informatie binnen het kader van deze hypothese interpreteert. Was er geen verband tussen de procesvariabelen en de diagnostische accuraatheid bij de afzonderlijke toetsingen (per casus), er bleek wel een verband tussen twee procesvariabelen en de diagnostische accuraatheid indien de gemiddelden over meerdere situaties als uitgangspunt werd genomen. Deze variabelen waren: 1. de hoeveelheid ingewonnen kritische probleeminformatie en 2. de juistheid van de interpretatie. Beide variabelen zijn te herleiden tot de inzet van inhoudelijke kennis gedurende het proces. Tenslotte zagen we in de studie van Johnson et al. (1981) dat op basis van een computersimulatiemodel twee condities konden worden voorspeld waaronder fouten kunnen voorkomen in het diagnostisch proces. Beide fouten-categorieën worden verondersteld voort te vloeien uit onvoldoende precisie van de kennis m.b.t. de ziekte of aandoening die had moeten worden vastgesteld. Deze veronderstelling, namelijk dat de precisie en de omvang van domeinspecifieke kennis de kwaliteit van een diagnose bepalen, is de basis voor de studies die in dit proefschrift gerapporteerd worden. Aan deze studies ligt het volgende model ten grondslag (Figuur 2). De dichte vakken betreffen de informatie-toestanden: 1. probleembeschrijving (alle objectieve probleeminformatie die beschikbaar is, of beschikbaar kan komen), 2. probleemrepre- 
Figuur 2: Model van informatie-verwerking en probleemoplossen (De Jong, 1986)

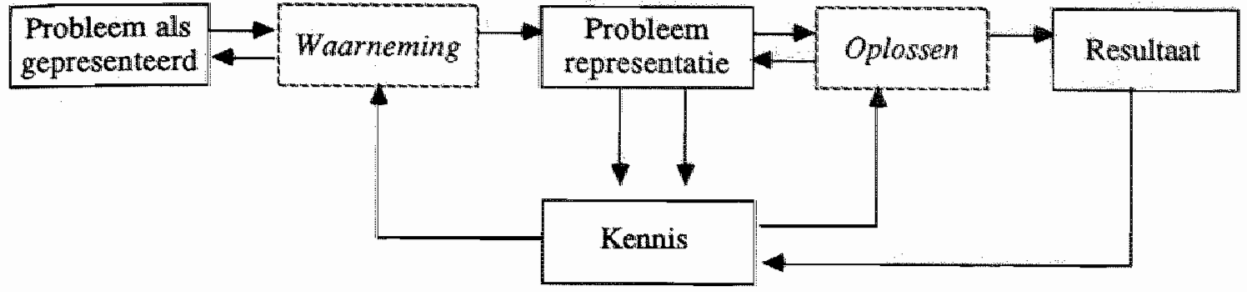

sentatie (het beeld dat de probleemoplosser vormt van de probleeminformatie), 3. resultaat (in ons onderzoek de diagnose) en 4. kennis (alle probleemrelevante kennis die ingezet kan worden). De open vakken betreffen de processen. De informatiestromen zijn aangegeven met pijlen.

De centrale rol van de kennis in het probleemoplossingsproces wordt zichtbaar door de rechtstreekse verbinding met alle overige componenten in het model. De kennis beïnvloedt in eerste instantie de perceptie van de probleemoplosser waarna het initieel concept (de voorlopige probleemrepresentatie) tot stand komt. Dit initieel concept wordt "vergeleken" met de kennis. Anders gezegd, dit is de interpretatie van de gegevens in het licht van de aanwezige kennis. Het resultaat van deze vergelijking kan leiden tot twee acties: herordening van de voorlopige probleemrepresentatie of aanvulling van de voorlopige probleemrepresentatie door nieuwe gegevens te verzamelen. Ook deze nieuwe informatie zal worden geïnterpreteerd en kunnen leiden tot herordening waardoor een cyclisch proces ontstaat dat wordt afgebroken indien de balans optimaal is tussen de probleemrepresentatie en de objectief waarneembare informatie. Het resultaat van het oplosproces wordt ook toegevoegd aan de kennis van de probleemoplosser. Dit is het dynamische aspect van het model, de kennis van de probleemoplosser wordt uitgebreid met ervaringskennis, die het resultaat is van het diagnostisch proces zelf.

In de studie van Johnson et al. (1981) werden de fouten die kunnen optreden in dit redeneerproces toegeschreven aan het ontbreken van voldoende precisie in de probleemrelevante kennis. De houdbaarheid van deze verklaring is toetsbaar door de resultaten van afzonderlijke metingen van kennisbeheersing en probleemoplosvaardigheid met elkaar te vergelijken. Een schatting van de sterkte van dit verband tussen beide variabelen kan ontleend worden aan de studie van Norcini, Meskauskas, Langdon en Webster (1986). In deze studie werden de correlaties berekend tussen beschikbare 
Tabel 2: Correlaties tussen kennismetingen en scores op computersimulatie wan probleemoplosisen (Norcini et al., 1986, p. 298)

Anamnese $\begin{gathered}\text { Lich. } \\ \text { onderzoek }\end{gathered} \begin{gathered}\text { Lab- } \\ \text { onderzoek }\end{gathered}$ Diagnose Therapie

\begin{tabular}{lccccc}
$\begin{array}{l}\text { Betrouwbaarheid } \\
\text { simulatiescores }\end{array}$ & .60 & .57 & .28 & .14 & .18 \\
\cline { 2 - 6 } A-type & $.28(.39)$ & $.27(.39)$ & $.32(.66)$ & $.30(.87)$ & $.29(.75)$ \\
X-type & $.22(.30)$ & $.24(.33)$ & $.30(.59)$ & $.41(1.0)$ & $.26(.64)$
\end{tabular}

scores van eerder afgenomen kennistoetsen en scores die werden toegekend op basis van het gedrag in een computersimulatie van een arts-patiënt contact (CASE) ${ }^{4}$. Het resultaat van deze analyse is weergegeven in Tabel 2.

In de simulatie werden de volgende deelvaardigheden onderscheiden: het afnemen van een anamnese, het uitvoeren van een lichamelijk- en laboratorium-onderzoek, het stellen van de diagnose en de keuze voor de therapie. In de kennismeting werd een onderscheid aangebracht met betrekking tot de vormgeving van de items in de gebruikte kennistoetsen. A-type items bevatten een langere inleiding (onderzoeksgegevens van een patiënt bijvoorbeeld) met een afsluitende meerkeuze-vraag, X-type items zijn de typisch kort geformuleerde toetsitems voor het meten van de beheersing van feitenkennis. In Tabel 2 worden telkens twee correlaties gerapporteerd. De eerste correlatie is de geobserveerde waarde, de tussen haakjes gerapporteerde correlatie is een schatting van de "ware" correlatie. Deze schatting is het resultaat van een correctieberekening voor attenuatie ${ }^{5}$. Correlaties worden name-

"De grondslag voor de berekening van de sterkte van het verband tussen kennis en probleemoplossen in deze studie van Norcini et al is de berekening van de waliditeit van "performance-based tests". Een onderdeel van de resultaten van deze studie wordt hier besproken ter illustratie van soortgellijke studies waarin de betrouwbaarheid en validiteit van toetsen van de vaardigheid in medisch probleemoplossen worden vergelleken met beschikbare gegevens over kennismetingen. Zie voor een uitvoerig overzicht van deze studies Swanson (1987) en Swanson, Norcini en Grosso (1987).

Correlaties tussen geobserveerde scores kunnen lager zijn dan de correlaties tussen de ware scores omdat de eerstgenoemde correlaties geattenueerd zijn door de onbetrouwbaarheid van de meetinstrumenten. Als de betrouwbaarheden bekend zijn kan de ware correlatie berekend worden door bepaalde contectieformules toe te passen. (Lord en Novick, 1968) 
lijk beïnvloed door de betrouwbaarheid van de meetresultaten. Na correctie voor attenuatie blijkt vooral de accuraatheid van de diagnose hoog te correleren met de kennismetingen. Dit zou geinterpreteerd kunnen worden als een aanwijzing voor de belangrijke rol van kennis bij het diagnostiseren van problemen. Nog afgezien van de vraag of de correctie voor attenuatie een aanvaardbare bewerking van ruwe correlaties is, is een moeilijkheid bij de interpretatie van deze data dat niet wordt aangegeven welke inhoudelijke overeenstemming er bestaat tussen de verschillende toetsitems en de simulatie. Gezien de aard van de studie waaraan deze gegevens zijn ontleend (validiteitsstudie van simulaties) mag verwacht worden dat deze inhoudelijke afstemming minimaal geweest is. De veronderstelling dat het ontbreken van precieze kennis de belangrijkste verklarende factor vormt voor foute probleemoplossingen is echter slechts toetsbaar door proefpersonen een probleem te laten oplossen en de resultaten hiervan te vergelijken met de resultaten van een op de inhoud van het probleem gebaseerde kennistoets, die dus alle probleemrelevante kennis omvat die bij het oplossen van dat probleem gebruikt moet worden. De twee eerste studies zullen aan deze probleemstelling zijn gewijd. Beide studies rapporteren metingen van kennis en probleemoplosvaardigheid met behulp van instrumenten die zo geconstrueerd werden dat de inhoudelijke overeenkomst maximaal was. In de eerste studie wordt het verband onderzocht tussen kennisniveau en probleemoplosvaardigheid waarbij het verband tussen kennis en probleemoplossen op schaal-niveau geanalyseerd werd. In de tweede, meer gedetailleerde studie, worden de kansen op een goede probleemoplossing berekend onder de conditie dat relevante kennis aanwezig is. Hierbij werd de rol van kennis als conditie voor probleemoplosvaardigheid op item-niveau geanalyseerd. Beide studies richtten zich dus exclusief op de relatie tussen in het geheugen aanwezige kennis en een uiteindelijke diagnose, zonder acht te slaan op de in Figuur 2 veronderstelde intermediërende processen. In Hoofdstuk 4 worden de resultaten van een experiment gerapporteerd, waarin getracht werd de vorming van de probleemrepresentatie tijdens het probleemoplosproces actief te beinvloeden. De veronderstelling daarbij was dat, door een voorlopige probleemrepresentatie te suggereren relevante kennis zou worden geactiveerd die de oplossing van het probleem zou vergemakkelijken. De vierde en laatste studie van dit proefschrift (Hoofdstuk 5) richt zich meer direct op de inhoud van de probleemrepresentatie en zijn relatie met de uiteindelijke diagnose. Daarnaast werd probleemrelevante voorkennis op een zodanige wijze gemeten dat het mogelijk werd naast kwantitatieve, ook kwalitatieve aspecten van die kennis te meten en in verband te brengen met probleemrepresentatie en diagnose. Het proefschrift sluit af met een integrale bespreking van de resultaten van de vier afzonderlijke studies in 
het kader van fundamenteel onderzoek naar geheugenprocessen waarbij de betekenis hiervan voor de onderwijspraktijk worden aangegeven. 


\section{HOOFDSTUK 2}

\section{Het verband tussen kennisniveau en vaardigheid in het oplossen van fysiotherapeutische problemen}

\section{Inleiding}

In dit hoofdstuk zal het verband tussen kennisbeheersing en vaardigheid in het oplossen van fysiotherapeutische problemen aan de orde worden gesteld. Dit gebeurt door middel van de presentatie van de resultaten van een onderzoek dat werd uitgevoerd bij 95 fysiotherapie-studenten. In het onderzoek werden de prestaties van deze studenten op een kennistoets gerelateerd aan gegevens die werden verkregen bij het oplossen van twee casus uit de fysiotherapeutische praktijk.

De rol van domeinspecifieke kennis in het oplossen van problemen werd object van onderzoek na de resultaten van onderzoeken die in Hoofdstuk 1 reeds uitvoeriger besproken zijn en die hier puntsgewijs nog eens worden samengevat:

1. Indien personen verschillende problemen uit een zelfde domein krijgen gepresenteerd treedt variabiliteit in hun prestaties op. Dat wil zeggen dat de vaardigheid in het oplossen van één probleem nog niet impliceert dat ook een volgend probleem succesvol wordt opgelost. Algemene kennis die gebruikt zou worden bij het probleemoplossen verklaart deze variabiliteit dus onvoldoende ${ }^{\sharp}$.

2. In onderzoek naar effecten van pogingen de vaardigheid in het oplossen van problemen te verbeteren, werd duidelijk dat gerichte training in algemene oplosmethoden geen overdraagbaar effect heeft. Dergelijke methoden richtten zich op de systematiek van probleem-analyse, procedures, etc. In experimenteel onderzoek werd aangetoond dat de proefpersonen in experi-

\footnotetext{
Onder de aanname dat deze algemene kennis constant blijft bij het oplossen van verschillende problemen in thetzelfite domein.
} 
mentele groepen weliswaar systematischer werkten. Echter, er was geen sprake van transfer van deze verworven algemeen-methodische kennis naar nieuwe probleemtaken: nieuwe problemen werden niet beter opgelost door de proefpersonen uit experimentele groepen in vergelijking met proefpersonen uit een controle-groep.

Dit alles betekent dus dat wanneer het erom gaat te verklaren waarom sommige mensen een probleem wel, en anderen dat probleem niet kunnen oplossen kennis van algemene probleemoplosmethoden tekort schiet. Specifieke domeinkennis zou dat wellicht echter wèl kunnen.

Zoals in Hoofdstuk 1 reeds werd geconcludeerd, werden verschillende studies uitgevoerd naar de relaties tussen probleemoplossen en bezit van domeingebonden kennis. Veelal betrof het hier studies waarin de meting van een algemeen kennisniveau, dus een kennismeting over een steekproef uit het complete domein, gecorreleerd werd met een of andere maat voor probleemoplosvaardigheid. Deze studies hadden over het algemeen teleurstellende uitkomsten. Dit werd onder andere toegeschreven aan het feit dat er geen sprake was van een inhoudelijke afstemming tussen de instrumenten waarvan het verband werd onderzocht. Deze studies probeerden de volgende algemene vraag te beantwoorden: "Kan een student die 'veel weet' van een bepaald domein ook 'goed probleemoplossen' in dat domein?" Het probleem daarbij is dat iemand in zijn algemeenheid een behoorlijk kennisniveau kan hebben, maar bijvoorbeeld juist geen, of weinig, kennis bezit die nodig is voor het oplossen van de voorgelegde problemen. Of anders, de kennis die benodigd was voor het oplossen van de voorgelegde problemen, was wellicht geen onderdeel van de kennistoetsing. $\mathrm{Om}$ een goed beeld te krijgen van de rol die kennis speelt bij het oplossen van problemen kan niet volstaan worden met een globale kennismeting in het betreffende vakgebied, maar zullen de instrumenten die daarbij gebruikt worden, inhoudelijk hetzelfde (sub-)domein moeten bestrijken: de kennistoets zal de aanwezigheid van kennis moeten meten die specifiek van toepassing is op de voorgelegde problemen. In dit hoofdstuk zal een eerste studie gerapporteerd worden waarin daartoe een poging wordt gedaan. Ons is slechts een enkel voorbeeld bekend waarin op gelijke wijze onderzoek werd uitgevoerd (Norman, Tugwell, Feightner, Muzzin en Jacoby, 1985).

De hypothese over de kennisafhankelijkheid van probleemoplossen die in deze studie getoetst zal worden is de volgende: 
Tussen scores van kennistoetsen en probleemoplostoetsen met inhoudelijke verwantschap bestaat een sterker verband dan tussen de scores van probleemoplostoetsen onderling ${ }^{2}$.

Als onze data deze hypothese zouden bevestigen, zou dat betekenen dat de beheersing van specifieke kennis een sterkere rol speelt in de mate van succes in het uitvoeren van een probleemtaak dan algemeen-methodische kennis.

\section{Studie 1: Het verband tussen kennis en probleemoplos- sen in het fysiotherapeutisch domein: analyse op basis van composiet-scores}

\section{Methode}

\section{Proefpersonen}

De onderzochte groep studenten fysiotherapie ( $\mathrm{N}=95$ ) was afkomstig uit drie verschillende opleidingen: de Hogescholen van Heerlen $(n=38)$, Den Haag $(n=26)$ en Deventer $(n=31)$. Alle studenten werden getoetst kort voor het begin van de één jaar durende praktijkleerperiode en hadden de hierop voorbereidende onderwijsperiode van $21 / 2$ jaar afgesloten. De proefpersonen participeerden op vrijwillige basis in het onderzoek. Zij werden geworven via een brief van de onderzoekers en kregen vooraf, indien gewenst, mondelinge toelichting over de achtergrond van het onderzoek. De studenten werden na afsluiting van het onderzoek beloond met een kleine vergoeding. Achteraf is op basis van gegevens over de studieprestaties (afkomstig van de opleidingen zelf) gecontroleerd of de deelnemers representatief waren voor de totale groep derdejaars van de desbetreffende opleiding. Deze controle kon alleen uitgevoerd worden in Den Haag en Deventer en was positief. De gemiddelde toetsresultaten van de deelnemende proefpersonen met betrekking tot kennis vertoonde slechts een geringe afwijking met de totale jaargroep waaruit de selectie afkomstig was. In de rapportage van de onderzoeksresultaten ligt het aantal proefpersonen soms lager dan 95. Dit is te wijten aan het feit dat de afname van de verschillende toetsen verspreid was over verschillende dagen. Bij afwezigheid van een student op

${ }^{2}$ We weronderstellen dat probleemoplostoetsen onderling laag correleren op grond van het eerder gerefereerde onderzoek. 
éến der toetsdagen werd deze persoon verder buiten het onderzoek gehouden.

\section{Meetinstrumenten}

Voor deze studie werden zoals gezegd twee typen meetinstrumenten ontwikkeld. Twee casus om vaardigheid in het diagnostiseren te meten, en twee kennistoetsen om de aanwezigheid van de casus-relevante kennis te meten. De casus werd eerst ontwikkeld, de inhoud van de kennistoets werd op grond hiervan vastgesteld. In de hypothese wan deze studie wordt het verband onderzocht tussen metingen van kennis en probleemoplossen binnen eén sub-domein. Dit werband wordt vervolgens vergeleken met het verband tussen verschillende metingen van probleemoplossen over verschillende sub-domeinen. Derhalve werden twee casus en twee kennistoetsen ontwikkeld. De eerste casus betrof een 'schouderklacht', en in de tweede casus was een 'bovenarmfractuur' het onderwerp. Probleemoplossen werd gemeten door middel van een schriftelijke presentatie van alle onderzoeksgegevens die bij een bepaalde klacht kunnen leiden tot een specifieke diagnose $^{3}$. Beide casus hadden de vorm van een boekje met gemiddeld 10 pagina's tekst op A-4 formaat. De tekst was geordend in een aantall rubrieken die chronologisch overeenstemmen met het verloop van een standaard fysiotherapeutisch onderzoek.

Deze rubrieken zijn: 1. Anamnese (een uitgebreide samenvatting van een gesprek tussen therapeut en patiënt onder toevoeging van relevante patiënt-gegevens en gegevens uit de verwijzing van de arts). 2. Inspectie (gegevens over inspectie, algemeen en lokaal, in diverse houdingen). 3. Onderzoek en tests (gegevens m.b.t. onderzoek van diverse lichaamsregio's en gewrichten, zowel actief als passief. Vaak werden houding van de patiënt en de handelingen van de therapeut kort beschreven waarop de bevindingen van deze onderzoekshandelingen volgden). 4. Metingen (meetgegevens m.b.t. o.a. spierkracht, spierlengte, sensibiliteit en reflexen. Bij elke

"In vergelijkbare studies naar probleemoplossen binnen verwante domeinen wordt vaak gebruik gemaakt wan een simulatie. Daarbij is het gedrag van proefpersonen binnen de gesimuleerde situatie onderwerp van onderzoek. Deze simulaties hebben vaak de vorm van kaartspellen of computersimulaties (Gerritsma en Smal, 1982). Deze vormen zijin niet gekozen voor deze studie om een tweetal redenen. In de eerste plaats zijn simulaties erg tijdsintensief. Het is daarom onmogelijk om met een groot aantal proefpersonen in een kort tijdsbestek te werken. In de tweede plaats is de vraagstelling in deze studie niet gericht op het proces van probleemoplossen maar op het resultaat van dit proces: de diagnose. 
meting werd de gehanteerde norm vermeld). 5. Palpatie (gegevens over de palpatie van diverse lichaamsregio's).

De complete casus bevatte meer informatie dan strikt noodzakelijk was voor de specifieke diagnose. Dit werd gedaan om de volgende redenen. De beginrubrieken anamnese en inspectie kunnen aanleiding geven tot verschillende hypotheses. Zowel bevestiging als uitsluiting van verschillende hypotheses moest mogelijk zijn. Bovendien is het in de praktijk mogelijk dat, mede afhankelijk van de fysiotherapeutische achtergrond of opvatting, verschillende onderzoekshandelingen kunnen worden gekozen bij én onderzoekshypothese: het instrument moest dus informatie bevatten die deze strategie mogelijk maakt. In de eindfase van de instrument-ontwikkeling zijn beide casus voorgelegd aan een groep ervaren fysiotherapeuten. Hen werd gevraagd te beoordelen of de casus voldoende gegevens bevatte voor de bevestiging van de door ons gesuggereerde diagnose. De resultaten van deze beoordeling zijn verwerkt in de definitieve versie van de twee casus.

De hoeveelheid tekst was zo omvangrijk (zoals gezegd gemiddeld 10 pagina's) dat voorkomen werd dat door slechts een vluchtige kennisname van de gegevens een diagnose kon worden geformuleerd. De meest efficiente werkwijze in deze toetsvorm is een grondige bestudering van de gegevens uit anamnese en inspectie om vervolgens op basis van expliciete verwachtingen de resterende gegevens uit de overige rubrieken te interpreteren.

Tabel 1: Fragmenten uit de casustekst voor de verschillende rubrieken

\section{RUBRIEK 1: ANAMNESE}

VERWTJZING:

- Naam:

- Adres:

- Geboortedatum:

- Geslacht"

- Beroep:

- Diagnose:

- Medische behandeling:

- Behandelopdracht:

- Verwijzer:

- Bijzonderheden:

- Verzekerd:
Hans van de Winkel

Ruitersweg 12, Tilburg

16-02-1946

man

glazenwasser

P.H.S.

verwijzing naar fysiotherapie

gaarne Uw therapie

huistarts

geen

particulier

ANAMNESEGESPREK:

Ik ben gisteren naar de dokter gegaan. Hij heeft mij naar $U$ gestuurd. Ik ga bijna nooit naar de dokter, maar nu kan ik niet meer werken. De eerste keer dat ik wat voelde was 
net de verhuizumg. Dat is nu 10 dagen geleden. Toen had ik "s-avonds wat spierpijn rond de schouder. In de loop van de volgende dag werd het erger. Toen ik het kozijn was an het schuren, moest ik af en toe ophouden met werken. Ik hield dan op vanwege de pijn. Ik heb me niet gestoten. Ik heb me ook niet vertild.

Een jaar geleden heb ik net zo iets gehad. Vlak voor de vakantie was dat. Toen had ik ook ontzettend hard gewerkt. Toen was de pijn veel mander. Het is ook wanzelf overgegaan. Maar nu geloof ik nilet dat het vanzelf overgaat. Nu werd ook eerst wat minder, mat na enige dagen weird het weer erger.

\section{RUDRIEK 2: INSPECTIE}

INSPECTIE IN STAND, GEWOONTEHOUDNG

- algemene indruk:

- normaal postuur

- atletisch gebouwd

- witpuilend abdomen

-kyfotische thoracale wervelkolom

- lokale inspectie:

Elke lichaamsregio wordt beoordeeld op: vorm, reliëf, afmeting, stand en kleur

- spinae iliacae posteriores superior even hoog

- christaranden even hoog

- scoliose lumbaal convex naar links, top \pm lumbalal 3

-scoliose thoracaal convex naar rechts, top \pm thoracaal 8

- de spina scapula is rechts beter zichtbaar dan links

- de nek/schouderlijn is rechts korter

- okselcontact is rechts langer

- spinae iliacae anteriores superior even hoog

- pars acromialis claviculae staat rechts hoger

- Schoudertop is links ronder dan rechts

- de transversale as door de heupgewrichten staat woor de lijn: centrum schoudergewricht/centrum enkelgewricht

- diepe cervicale lordose

- naar voren geschoven hoofd

\section{RUBRIEK 3; ONDERZOEK EN TESTS}

\section{ONDERZOEK CERVICALE WERVELKOLOM}

Actief bewegingsonderzoek: Beoordeeld worden: bewegingsverloop, uitslag en pijn

- Anteflexie: ca. $10^{\circ}$ beperkt ten opzichte van de passieve bewegingsmogelijkheid.

Bij het bereiken wan de eindgrens treedt pijn op. Pijn is goed te verdragen en wordt mid-cervicaal aangegeven.

- Retroflexie: vindt voomamelijk hoog cervicaal plaats.

- Rotaties: met de thoracale wervelkolom in gewoontehouding (sterk kyfotisch) is geen meebewegen zichtbaar van de hoog thoracale processus spinosi. Is de thoracale wervelkolom maximaal gestrekt is meebewegen zichtbaar.

- Lateroflexie rechts: g.b.

- Lateroflexie links ca. $10^{\circ}$ beperkt t.o.v." de actieve lateroflexie naar rechts. Er is geen piljn. 


\section{RUBRIEK 4: METINGEN}

SPIERLENGTEMETINGEN Gehanteerde norm staat büj elke lengtemeting vermeld

- Patiënt: ruglig, armen langs romp

Fysiotherapeut: fixeert schouder voert een cervicale heterolaterale lateroflexie uit.

Uitslag lateroflexie:

- naar rechts $\pm 50^{\circ}$

- naar links $\pm 40^{\circ}$

- norm $\pm 45^{\circ}$

\section{RUBRIEK 5: PALPATIE}

Per regio wordt een indruk verkregen over: huid en onderhuids bindweefsel, gewrichtskapsels en ligamenten, botstructuren, spier- en peesstructuren, zenuwen en bloedvaten

Palpatie in rust:

- Regio vertebralis en cervicalis:

Op processus spinosus $\mathrm{C} 3$ na zijm alle doomuitsteeksels goed palpabel. Bij het geven van een impuls naar ventraal geeft $\mathrm{C5}$ pijn paravertebraal.

De paravertebrale musculatum ter hoogte van $\mathrm{C} 4 \mathrm{t} / \mathrm{m} \mathrm{C} 7$ is rechts drukgevoeliger en verminderd indrukbaar.

- Regio suprascapularis:

De musculatuur die de contour van de rechter nek/schouderlijn bepaalt is drukgevoeliger en verminderd indrukbaar.

$\mathrm{Na}$ afronding van de casus-constructie werd de inhoud zorgvuldig geanalyseerd op een beperkt aantal, voor de diagnose relevante, concepten uit de leerstofgebieden anatomie, kinesiologie, pathologie en fysiotherapeutisch onderzoek. Op basis van deze analyse werd het tweede instrument, de kennistoets, samengesteld. Op deze wijze was een optimale inhoudelijke overeenkomst tussen kennistoets en casustoets gewaarborgd. De elementen van één casus werden omgezet in 15 inhoudelijk representatieve proposities die met 'juist' of 'onjuist' beantwoord konden worden. Een voorbeeld van een item is het volgende:

Een painful-arc tussen $80^{\circ}-120^{\circ} \mathrm{kan}$ duiden op een subacromiale compressie van het oppervlakkige teno-periostale deel van de musculus supraspinatus. (juist)

Deze propositie kan worden beantwoord met het omcirkelen van het alternatief 'juist' of 'onjuist'. Als men onvoldoende zeker was kon gekozen wor- 
den voor het tussen-alternatief '?' (= weet ik niet). Het beantwoorden van dit woorbeeld-item vraagt wan de proefpersoon een geintegreerde beheersing van kennis uit verschillende basisvakken, in dit geval van anatomie, kinesiologie en pathologie.

\section{Procedure}

Om de kans te verkleinen dat de proefpersonen de inhoudelijke overeenkomsten tussen de verschillende toetsen zouden zien (en eventueel als ongewenste hint zouden gebruiken) is gekozen voor een gefaseerde presentatie van de toetsen. Minimaal 1 week en maximaal 2 weken na de afname van beide kennistoetsen werden de casus afgenomen. Bovendien werd de proefpersonen verteld dat het hier een onderzoek betrof naar de kwaliteit van verschillende toetsvormen. Alle toetsen zijn groepsgewijs in één ruimte afgenomen. De verschillende toetsen werden kort toegelicht door de proefleider. In de mondelinge toelichting van de kennistoets werd benadrukt dat het raden naar antwoorden vermeden moest worden. De kennistoetsen bevatten bovendien de volgende instructie:

Op de volgende bladzijden vindt $U$ een antal vragen die $U$ allemaal moet beantwoorden. De vragen zijn geformuleerd in de vorm van uitspraken die juist of onjuist zijn. Het door $\mathbb{U}$ gekozen altematief moet $U$ omcirkelen. Er is ook een derde antwoordmogelijkheid: "Ik weet het miet". Daarvoor staat het vraagteken. Wij adviseren $\mathrm{U}$ alleen die vragen met 'juist" of "onjuist" te beantwoorden waarvan $\mathrm{U}$ zeker bent.

Voor de kennistoetsen gezamenlijk was maximaal 1 uur beschikbaar.

Voor beide casus werd een tijdslimiet gehanteerd van $11 / 2$ uur voor eén casus. Ook deze toets werd mondeling kort toegelicht waarbij in het bijzonder aandacht werd besteed aan de gewenste diagnoseformulering. Deze toets bevatte daartoe de volgende instructie:

In het bijbehorende boekje is een volledige casus uit de fysiotherapeutische praktijk beschreven. De inhoud van de casus is geordend in 5 rubrieken:

1. anamnese

2. inspectie

3. onderzoek en tests

4. metingen

5. palpatie 
$\mathrm{U}$ moet alle gegevens rustig doorlezen. Daarbij mag $U$ aantekeningen maken als $U$ belangrijke gegevens apart wilt houden. Als $U$ de casus voldoende hebt bestudeerd moet $U$ de volgende opdracht uitvoeren:

Op het antwoordformulier met het kopje DIAGNOSE geeft U de diagnose op orgaanniveau. Dit is een deel van de diagnose dat kan dienen als uitgangspunt voor het opstellen van een behandelplan.

Een voorbeeld: De diagnose 'tenniselleboog type II' is in dit opzicht fout. Beter is om te spreken van een 'insertie tendopathie musculus extensor carpi radialis brevis".

Bedenk dat een diagnose uit meerdere elementen kan bestaan.

Bijvoorbeeld: "Er is sprake van een ruptuur wan lig. collaterale medialle en een laesie van de mediale meniscus met als gevolg een antero-mediale knie-instabiliteit".

Analyse

Voor de analyse van het verband tussen de aanwezigheid van probleemrellevante kennis en de kwaliteit van de probleemoplossing zijn vier composietscores gebruikt: twee diagnose-scores en twee kennis-scores.

De diagnose-scores zijn composiet-scores die inhoudelijk gevalideerd werden door de diagnose-items van de desbetreffende schalen vooraf te laten beoordelen door experts. De beide casus zijn verzonden aan 20 fysiotherapeuten met minimaal 3 jaar ervaring in de specifieke domeinen waarop de casus-toetsen betrekking hebben. De experts werd gevraagd bij de beoordeling de volgende procedure te volgen. Eerst moest de tekst van de casus bestudeerd worden en moest men een eigen diagnose formuleren. Deze diagnose moest vervolgens vergeleken worden met onze diagnose die in een gesloten enveloppe bij de tekst was gevoegd. Op een commentaarformulier kon men onze diagnose becommentariëren. Tenslotte moesten de experts op het commentaar-formulier de elementen van de diagnose rangordenen naar belangrijkheid. Het commentaar op de diagnose kon op twee manieren gegeven worden. De beoordelende expert kon ofwel de diagnose bijstellen, ofwel gegevens suggereren die in de casus moesten worden opgenomen teneinde de juistheid van de gesuggereerde diagnose te rechtvaardigen. Er werd uitsluitend gebruik gemaakt van de tweede commentaaroptie: casus-aanvullingen en -wijzigingen. Het betroffen marginale opmerkingen die de kern van de voorgestelde diagnoses niet aantastten.

De diagnose-formuleringen die ter beoordeling werden voorgelegd waren lopende teksten in zinnen. Onderstaande tekst is een illustratie van de vorm waarin de antwoord-sleutels zijn voorgelegd aan de groep experts. 
"Tendinitis van de M. supraspinatus rechts ter hoogte van de tenoperiostale overgang. Zowel diep als oppervlakkig. Het is een tendinitis in het $4 \mathrm{e}-5 \mathrm{e}$ stadium.

Er is sprake van een arthritis van het articulatio glenohumerale rechts. Met bewegingsbeperkingen volgens het kapsulaire patroon. Het is een arthritis in het $2 \mathrm{e}-3 \mathrm{e}$ stadium.

Bij onderzoek van de cervicale wervelkolom blijkt dat bij belasting van het voorste deel wan her bewegingssegment klachten optreden. Misschien is er sprake van een discusdegeneratie. Madere differentiatie wan de nekklacht is op basis van deze gegevens niet mogelijk."

Deze tekst bevat de wolgende componenten voor de feitelijk te hanteren antwoord-sleutel:

- actualiteit arthritis (5)

- actualiteit tendinitis (6)

- arthritis (1)

- articulatio glenohumerale (3)

- discusdegeneratie (9)

- kapsulair patroon (7)

- musculus supraspinatus (4)

- tendinitis (2)

- teno-periostaal (8)

De cijfers tussen haakjes zijn de resultaten van de rangordening naar belangrijkheid (de latste stap uit de beoordelingsprocedure van de experts). De experts werd gevraagd de componenten te rangordenen naar belangrijkheid om eventueel een gewogen score te kunnen berekenen van de proefpersonen. Ondanks de eenstemmige onderschrijving door de experts van de antwoordsleutels voor de beoordeling van de diagnose-formuleringen van de proefpersonen bestond er weinig eensgezindheid over de mate van belangrijkheid van de verschillende componenten. Over de uitersten van de schaal 'belangrijk (1)' - 'weinig belangrijk (9)" was men het wel eens (met name ten aanzien van de minder belangrijke onderdelen) maar ten aanzien van de tussenliggende begrippen was een grote spreiding constateerbaar. Daarom is afgezien van het hanteren van een gewogen score op basis van de expertoordelen. De diagnose-score in dit voorbeeld werd berekend op basis van het tellen van de aanwezigheid van de sleutel-componenten in de tekst van de proefpersonen (minimum-score $=0$ en maximum-score $=9$ ). Deze scoringstechniek was eenvoudig te hanteren. De antwoorden op de casus van alle deelnemers zijn door twee beoordelaars beoordeeld in de volgende procedure. Twee beoordelaars scoorden onafhankelijk van elkaar met de door 
experts gevalideerde sleutel een steekproef uit alle casustoetsen. De mate van overeenkomst tussen deze eerste beoordelingen bedroeg gemiddeld $85 \%$. Inhoudelijke analyse van de gevallen waarover geen overeenstemming bestond tussen de beoordelaars leidde tot een marginale aanpassing van de sleutel, vooral met betrekking tot de waardering van synoniemen of gelijkwaardige formuleringen. Met de gereviseerde sleutel werden nu alle toetsen opnieuw beoordeeld en gescoord door de twee beoordelaars. Dit leidde tot een mate van overeenkomst bij de schouderklacht-casus van $98 \%$ en bij de bovenarmfractuur-casus van $96 \%$. In alle gevallen waarover, na de tweede beoordelingsronde, een verschil van mening bestond hebben beide beoordelaars een gezamenlijke heroverweging gemaakt:

Ook voor het meten van de aanwezigheid van probleemrelevante kennis is gebruik gemaakt van composiet-scores. Het aantal goed beantwoorde items is voor elke schaal afzonderlijk geteld en verwerkt tot een totaalscore van het aantal goed beantwoorde items (range 0-15).

De kwaliteit van toetsen kan doorgaans op twee manieren worden geevalueerd: met behulp van de klassieke testtheorie en met behulp van de item-response theorie. Hoewel de eerstgenoemde evaluatie-methode verreweg het meest populair is onder onderzoekers, is éen van de nadelen van deze benadering dat de uitkomsten van het $k w$ aliteitsonderzoek van een meetinstrument op voorhand voorspelbaar zijn. Indien een relatief kort instrument wordt ontwikkeld (soms is bijwoorbeeld een lang instrument niet gewenst) kan men voorspellen dat éen van de indices om de kwaliteit van het instrument te bepalen, zijn betrouwbaarheid, laag uit zall vallen. In zo'n situatie kan beter de item-response theorie gebruikt worden om de kwaliteit van het ontwikkelde instrument vast te stellen.

In deze studie waren alle instrumenten relatief kort. Vandaar dat hier als analyse-methode een van de meest gebruikte modellen uit de item-response theorie is toegepast, het Raschmodel (Rasch, 1960). Met behulp van dit model kunnen de meeteigenschappen van het instrument statistisch vastgesteld worden. Blijkt een verzameling items aan de assumpties van het Raschmodel te voldoen, dan heeft die verzameling een aantal aantrekkelijke eigenschappen (Molenaar, 1983): schattingen van item-moeilijkheden zijn niet meer afhankelijk van de onderzochte steekproef, item-karakteristieke curves zullen parallelliteit vertonen en een éndimensionale ordening van personen en items is mogelijk. Dit zijn eigenschappen die de conclusie kunnen rechtvaardigen dat men te maken heeft met een instrument van voldoende kwaliteit.

De eigenschappen van de meetinstrumenten die in deze studie gebruikt zijn, werden onderzocht met behulp van het computerprogramma PML (Gustafsson, 1977). Als toets voor de model-fit werd de toets van Ander- 
son (Gustafsson, 1977) gebruikt. Hierbij werd de zogenaamde A-ICCSL variant gebruikt, die gevoelig is voor variaties in de hellingen van de itemkarakteristieke curves. Wanneer deze toets geen significante afwijkingen van het Raschmodel te zien geeft is de item-verzameling als een goed meetinstrument te beschouwen. Toetsing op Rasch-homogeniteit van de vier in deze studie gebruikte instrumenten leverde de volgende resultaten op: 'Kennis van Schouderklacht' Chi-kwadraat: 9.69, df $=14, p={ }_{\text {.78; }}$; 'Kennis van Bovenarmfractuur' Chi-kwadraat: 6.81 , df $=14, \mathrm{p}=.94$; 'Diagnose van Schouderklacht' Chi-kwadraat: 5.66, df $=6, \mathrm{p}=.46$; 'Diagnose van Bovenarmfractuur' Chi-kwadraat: 1.05 , df $=3, p=.79$. Uit deze resultaten blijkt dat alle meetinstrumenten voldoen aan de eisen van het Raschmodel. Er is, met andere woorden, geen bezwaar tegen het gebruiken van de meetresultaten in het verdere verloop van dit onderzoek.

\section{Resultaten en discussie}

Voorafgaande aan de toetsing van de hypothese met betrekking tot de verbanden tussen de verschillende metingen volgt eerst een overzicht van de resultaten in Tabel 2 . Opvallend is dat de gemiddelde prestaties op de casustoetsen relatief laag is en, eveneens, de bijbehorende standaarddeviaties.

Tabel 2: Overzicht kennisscores en diagnosescores van twee casus

\begin{tabular}{lcccc} 
Variabelen & Gemiddelde & Range & S.D. & N \\
\hline Kennis-schouderklacht & 7.21 & $2-12$ & 2.29 & 95 \\
Kennis-bovenarmfractuur & 6.40 & $2-11$ & 2.03 & 95 \\
Diagnose-schouderklacht & 3.23 & $0-6$ & 1.44 & 87 \\
Diagnose-bovenamfractuur & 1.76 & $0-4$ & .93 & 86
\end{tabular}

In de inleiding tot deze studie werd verondersteld dat het verband tussen de kennis-score en de diagnose-score binnen én subdomein sterker zou zijn dan het verband tussen de diagnose-scores wan verschillende subdomeinen. Een zwak verband tussen beide diagnose-scores mocht verwacht worden op basis van de in Hoofdstuk 1 besproken studies waarin bleek dat dezelfde personen, ongeacht het ervaringsniveau, met wissellend succes voorgelegde probleemtaken uitvoerden. Dit gegeven was de aanleiding tot de 
veronderstelling dat de beheersing van de tijdens het probleemoplossen benodigde kennis ten grondslag zou liggen aan de kwaliteit wan de probleemoplossing. Twee typen kennis werden onderscheiden in de analyse van de kennisafhankelijkheid van probleemoplossen: algemeen methodische kennis over fysiotherapeutisch onderzoek en specifiek inhoudelijke (casus-gebonden) kennis. Omdat de algemeen methodische kennis voor beide casus gelijk was (deze wordt verondersteld vooral afhankelijk te zijn van expertiseniveau, dat voor alle groepen gelijk was), werd verondersteld dat de kennisafhankelijkheid van probleemoplossen tot uitdrukking zou komen in sterkere verbanden tussen de kennis-score en de diagnose-score binnen de twee subdomeinen afzonderlijk dan in het verband tussen beide diagnose-scores onderling.

De resultaten van de toetsing van deze hypothese zijn samengevat in Tabel 3.

Tabel 3: Correlaties tussen kennisscores en diagnosescores

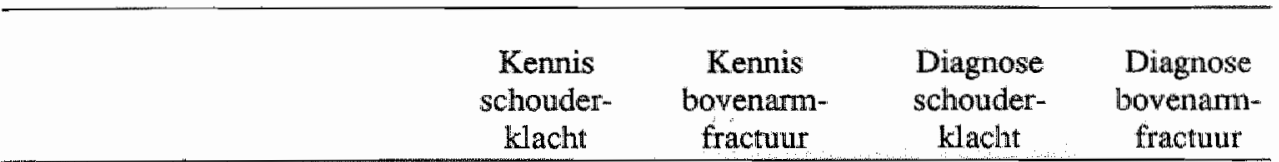

Kennis-schouderklacht

Kennis-bovenarmfractuur

$$
\begin{gathered}
.14 \\
\mathrm{p}=.082 \\
n=95
\end{gathered}
$$

Diagnose-schouderklacht

$$
\begin{gathered}
.28 \\
p=.004 \\
n=87
\end{gathered}
$$$$
\mathrm{n}=87
$$

Diagnose-bovenamfractuur

$$
\begin{gathered}
.29 \\
p=.003 \\
n=87
\end{gathered}
$$

.19

$\mathrm{p}=.038$

$\mathrm{n}=87$
.19

$\mathrm{p}=.043$

$\mathrm{n}=86$

Uit de gegevens in Tabel $3 \mathrm{kan}$ worden geconcludeerd dat de gestelde hypothese moet worden verworpen. De correlaties tussen de beide diagnosescores onderling zijn weliswaar overeenkomstig de verwachting laag ( $\mathrm{r}=$ .19), echter de correlaties tussen de kennis-scores en de diagnose-scores 
binnen de beide subdomeinen zijn ook relatief laag $(r=.28$ en $r=.19$ respectievelijk). Opwallend is dat kennis van schouderklachten even hoog correleert met de diagnostiek van de schouderklacht als met de diagnostiek van de bovenarmfractuur. De gevonden correlaties die in de $.20-.30$ range liggen, zijn niet hoger dan die, welke gevonden werden in de in Hoofdstuk 1 samengevatte studies naar de rol van algemeen-methodische kennis bij het oplossen van problemen. Uit deze gegevens kan dus worden geconcludeerd dat de beheersing van probleemrelevante kennis, zoals gemeten in de kennistoets, geen betere voorspeller is voor probleemoploswaardigheid dan algemeen-methodische kennis.

Men kan zich afvragen hoe dat komt. Natuurlijk zal de onverwachte moeilijkheidsgraad van de diagnose-toetsen een rol gespeeld hebben. De restrictie in variantie die daarvan het gevolg is, is zeker voor een deel verantwoordelijk voor de lage correlaties tussen domeinspecifieke kennis en diagnostische vaardigheid. Het feit echter dat de kennis-diagnose correlaties nauwelijks hoger zijn dan de kennis-kennis en diagnose-diagnose correlaties duidt erop dat voor succesvol probleemoplossen de beheersing van probleemrelevante basiskennis een onvoldoende voorwaarde is. Immers, indien de mate van succes in probleemoplossen direct bepaald zou worden door de beheersing van de kennis waarop in het probleem een beroep wordt gedaan, heeft dat twee consequenties: 1 . Bij afwezigheid van relevante kennis is de kans groot dat het probleem fout wordt opgelost. 2. Bij aanwezigheid van relevante kennis is de kans groot dat het probleem goed wordt opgelost. Deze proposities zouden tot hoge correlaties tussen kennis en diagnose moeten leiden.

Er kan echter nog een andere reden zijn waarom de gevonden correlaties zo laag zijn: de samengestelde of composiet-scores bij het zoeken naar een verband tussen de aanwezigheid van kennis en het gebruik van deze kennis werden toegepast bij het oplossen van een fysiotherapeutisch probleem zoals dit in de praktijk voorkomt. Wellicht waren in de hiervoor beschreven studie de gebruikte analyse-eenheden nog te grof. Immers, met de diagnose-score bij een casus wordt de mate van juistheid van een diagnose uitgedrukt in een totaal-som van de afzonderlijk gescoorde onderdelen van de diagnose-antwoordsleutel. Datzelfde geldt voor de som van 15 kennisitems. Door kennis en diagnostiek te definiëren als de som van op zichzelf wellicht heterogene eenheden, zou het verband tussen het bezitten van een dergelijke kenniseenheid en het gebruik daarvan verloren gegaan kunnen zijn. Met andere woorden: het niveau waarop verbanden gezocht werden is nog te globaal. Wellicht zou een analyse op item-niveau wel een verband kunnen aantonen, waarbij, het gedrag van proefpersonen op afzonderlijke items gerelateerd wordt aan elementen van het diagnostisch proces. 
Niet alleen de kennistest, maar ook het instrument voor de meting van de probleemoplossing zou een analyse op 'item-niveau' mogelijk moeten maken. Voor de toetsing van de vaardigheid in probleemoplossen is in de vormgeving van het meetinstrument voor de hierboven beschreven studie zo dicht mogelijk bij de fysiotherapeutische praktijk gebleven: de proefpersonen werd een probleem gepresenteerd in de vorm van een complete praktijk-casus. Terwille van de mogelijkheid tot analyse van het verband tussen kennis en probleemoplossen op item-niveau zal daarom in de in het volgende hoofdstuk te bespreken studie geen casus worden gebruikt maar een 'probleem-toets' die een verzameling is van 'deel-problemen' uit de fysiotherapeutische diagnostiek. Om analyses op 'item-niveau' te kunnen witvoeren wordt echter niet alleen gebruik gemaakt van correlatie-coëfficiënten maar ook van kansen, waarbij steeds berekend zal worden wat de kans is dat een diagnose-element correct is, gegeven het feit dat het daarop betrekking hebbende kennisitem juist beantwoord is.

\section{Conclusie}

In deze studie werd de sterkte van het verband onderzocht tussen de aanwezigheid van kennis en de vaardigheid deze kennis te gebruiken in het oplossen van een probleem. Daarbij werd gebruik gemaakt van instrumenten die enerzijds de aanwezigheid van de kennis meten, uitgedrukt in een kennis-score, en anderzijds de kwaliteit van de probleemoplossing meten die werd uitgedrukt in een diagnose-score. Beide instrument-typen waren gericht op dezelfde domeinkennis. Het gezochte verband was zwakker dan werd verwacht. In de discussie werd de mogelijkheid geopperd dat de zwakte van het verband verklaard zou kunnen worden uit de gebruikte analyse-eenheden: composiet-scores en correlaties. In de volgende studie zal opnieuw het verband tussen kennis en probleemoplosvaardigheid worden onderzocht, nu met andere analyse-eenheden: item-analyses en kansverhoudingen. 


\section{HOOFDSTUK 3}

\section{Kennis als noodzakelijke conditie voor probleemoplos- vaardigheid; \\ onderzoek naar de kans op een juiste probleemoplossing bij aanwezigheid van relevante voorkennis}

\section{Inleiding}

In het vorige hoofdstuk werd verslag gedaan van een poging kennis, gemeten met een uit 15 items bestaande kennistoets, te relateren aan het vermogen om succesvol een probleem op te lossen waarvoor de aanwezigheid. van die kennis een noodzakelijke voorwaarde geacht werd. Probleemoplossen en voor die problemen relevante kennis bleken slechts laag te correleren. Dit werd onder andere toegeschreven aan het feit dat het niveau waarop de analyse gedaan werd te globaal was om effecten van kennis op diagnostische prestaties te kunnen ontdekken. Met name de diagnostische taak zou wellicht te complex zijn (getuige ook de lage gemiddelde scores op die taak) om de rol van kennis zichtbaar te maken, in het bijzonder voor nog niet afgestudeerde fysiotherapeuten. Redeneringen over casus-onderdelen (bijwoorbeeld de gegevens van een specifieke test die de patiënt heeft ondergaan) in de vorm van deel-conclusies en de bundeling van deze deelconclusies tot een eind-conclusie, vergroot de kans tot het maken van redeneer-fouten. Het is uit onderzoek bekend dat met name studenten die als gevorderd, maar nog niet expert, beschouwd kunnen worden, veel tijd en energie steken in het al redenerend oplossen van problemen, terwijl ervaren hulpverleners in routinegevallen de aard van de aandoening veelal meteen herkennen en dus relatief weinig redeneren (Boshuizen \& Schmidt, 1990). Het mag dus niet uitgesloten worden dat daarbij fouten gemaakt worden die het zicht op het gebruik van kennis bij de oplossing van een probleem belemmeren. Daarbij komt nog dat kennis veelal een rol speelt bij het begrijpen en interpreteren van afzonderlijke informatie-eenheden, zeker bij studenten die bij het oplossen van problemen vaak 'stimulus-gebonden' re- 
deneren. Het was daarom wellicht wat al te optimistisch te verwachten die kenniseffecten in het uiteindelijke diagnostische resultaat gereflecteerd te zien.

Het is dus noodzakelijk dat de analyse gedetailleerder is dan met composiet-scores. Probleemeenheden die gerelateerd worden met kennismetingen zullen beperkt van omvang moeten zijn. In de in dit hoofdstuk te bespreken studie zullen de relaties tussen de aanwezigheid van kennis en probleemoplossen niet alleen worden uitgedrukt in termen van correlatie maar ook in termen van conditionele kansen: "Wat is de kans op het succesvol oplossen van een probleem indien relevante kennis voor het oplossen van dit probleem aanwezig is?". Zoals gezegd zal niet op het niveau van de test maar op het niveau van afzonderlijke items gezocht worden naar samenhang tussen verschillende metingen. Voor het meten van kennis werd dezelfde procedure gehanteerd als in studie 1 , voor het meten van probleemoplossen werd een nieuw instrument geconstrueerd dat problemen bevat die kunnen worden opgevat als afzonderlijk herkenbare onderdelen van een complete casus uit de praktijk. Op elk van die onderdelen kan een goed of fout antwoord gegeven worden en voor elk van die onderdelen is exact aan te geven welke kennis voor de oplossing daarvan noodzakelijk is. Indien de aanwezigheid van relevante kennis in overwegende mate bepalend is voor de mate van succes van het oplossen van een probleem zijn minimaal drie samenhangende voorspellingen mogelijk: Bij afwezigheid van kennis is de kans groot dat een probleem fout wordt opgelost. Bij aanwezigheid van kennis is de kans groot dat een probleem goed wordt opgelost. Daarnaast wordt een hoge correlatie tussen antwoordgedrag op een kennisitem en antwoordgedrag op een probleem-item verwacht.

\section{Studie 2: Het verband tussen kennis en probleemoplos- sen in het fysiotherapeutisch domein; analyse op item- niveau}

\section{Methode}

\section{Proefpersonen}

De proefpersonen in deze studie waren dezelfde studenten fysiotherapie van 3 verschillende opleidingen $(n=88)$ als in de eerste studie. Deze groep werd getoetst in de afsluitende fase van de theoretische voorbereiding op de praktrijkleerperiode (derde opleidingsjaar). De deelname aan het onderzoek geschiedde op vrijwillige basis en werd beloond met een kleine vergoeding. 
Op basis van gegevens over de studieprestaties van de opleidingen zelf is achteraf gecontroleerd of de vrijwillige deelnemers (alleen Deventer en Den Haag) representatief waren voor de totale jaargroepen waaruit zij afkomstig waren. Uit deze controle bleek dat er geen sprake was van een systematische afwijking in de samenstelling van de deelnemende groepen; deze studenten kunnen dus niet als atypisch worden beschouwd.

\section{Meetinstrumenten}

Ten behoeve van deze studie werden de meetinstrumenten, evenals die gebruikt in studie 1, zorgvuldig op elkaar afgestemd. In eerste instantie werd de probleem-toets ontwikkeld, waarna op basis van een inhoudsanalyse met inachtneming van de antwoordsleutels de kennistoets werd geconstrueerd. De toets die in deze studie werd gebruikt voor het toetsen van de vaardigheid in het oplossen van problemen, en die in het vervolg de 'probleemtoets' zal worden genoemd, week af van de casus-toetsen in de eerste studie. De probleem-toets bestond uit een verzameling deelproblemen zoals die in een complete casus aan de orde zouden kunnen komen. Hij kan gekarakteriseerd worden als een toets met open vragen en bestond uit 15 items. Elk probleem begon met een korte opdracht zoals in het volgende voorbeeld."

Opdracht: Geef aan waarop u de volgende onderzoekshandeling wilt richten in het kader van de diagnosestelling.

De heer P. van de W. is 28 jaar en doet aan atletiek. De laatste weken is hij intensief bezig geweest met speerwerpen. Hij heeft sinds twee weken last van zijn schouder. In het begin alleen na de training, maar nu ook tijdens het werpen. Hij kan geen trauma aangeven. De pijn is gelokaliseerd aan de voorzijde van de schouder en straalt iets uit naar de bovenarm. Bij het actief bewegingsonderzoek wan de schouder zijn er geen bijzonderheden. $\mathrm{Bij}$ het passief bewegingsonderzoek is het testen van het eindgevoel van de exorotatie licht pijnlijk aan de voorzijde van de schouder. Er is geen uitstraling. Laat de onderzoeker een abductie uitwoeren onder handhaving van een maximale glenohumerale exorotatie dan geeft de patiënt pijn aan tussen $120^{\circ}$ en $145^{\circ}$ abductie. De teruggaande beweging is niet pijnlijk. En bij herhaling van de test is de pijn niet altijd te provoceren.

Een andere voorkomende opdracht was: "Geef aan de hand van onderstaande gegevens de belangrijkste waarschijnlijkheidsdiagnose". Bij laatstgenoem-

Zie voor complete verzameling probleem-items bijlage 2 . 
de opdracht bevatte de probleemtekst in hoofdzaak een aantal gegevens uit fysiotherapeutisch onderzoek. De proefpersonen werd dus een serie problemen voorgelegd waarvan elke oplossing afzonderlijk op een dichotome schaal (goed of fout) beoordeeld kon worden. Ook deze toets is in de ontwikkelingsfase voorgelegd aan een groep van 20 experts met het verzoek om schriftelijk commentaar op probleemtekst en bijbehorende oplossing te geven. Slechts in enkele gevallen werden suggesties geleverd voor aanvullingen in de probleemtekst. Die suggesties zijn overgenomen.

Bij elk probleem-item werden 2 kennis-items geformuleerd. In het bovenstaande voorbeeld van de probleemtaak was de goede oplossing: "tendinitis (= peesontsteking) van de musculus subscapularis". Bij dit probleem en de oplossing hoorden de volgende twee kennis-items ${ }^{2}$ :

A. Als bij het herhalen van de beweging een aanvankelijk aanwezige painful-arc niet meer optreedt, dan heeft de painful-arc geen diagnostische walarde". (onjuist)

B. Een painful-arc gedurende de abductie/elevatie van de humerus met handhawing wan maximale gleno-humerale exorotatie kan veroorzaakt worden door het proximale deel van de insertie van de musculus subscapularis en het tuberculum minus ${ }^{4}$. (juist)

Samengevat zijn in deze studie twee sets van instrumenten gebruikt: een verzameling van 15 probleem-items en een verzameling van 30 kennisitems waarin telkens 2 items correspondeerden met één item uit de verzameling probleem-items.

Zie voor complete verzameling kennis-items bijlage 2 .

Toelichting: als pijn optreedt gedurende een deel van de beweging dan is er sprake van een pijnlijk traject (=painfui-arc). Een dergelijk pijnlijk traject kan slechts door bepaalde anatomische structuren worden veroorzaakt. Een pijnlijk traject is niet altijd reproduceerbaar. Herhaling van de beweging hoeft niet altijd dit traject opnieuw te provoceren. Met andere woorden, een eenmaal geconstateerd pijnlijk traject blijft zijn diagnostische warde behouden.

Toelichting: een painful-arc wordt veroorzaakt door compressie van bepaalde aangedane anatomische structuren gedurende een beweging. Het moment van optreden van het pijnlijk traject en de omstandigheden waaronder de beweging heeft plaats gehad bepalen mede welke anatomische structuren als oorzaak van de pijn in aanmerking komen. In de geschetste situatie, waarbij de arm geheven wordt met naar buiten gedraaide hand (exonotatie), is de daarbij aanwezige painful-arc terug te voeten op een compressie van de aanhechting (proximale deel van de insertie) van de musculus subscapularis of het botgedeelte van de bovenam (tuberculum minus) waarop die pees aanhecht. 


\title{
Procedure
}

De verzameling kennis-items werd op alle deelnemende opleidingen minimaal twee weken voorafgaande aan de verzameling probleem-items gepresenteerd. Beide toetsen werden groepsgewijs in Eén ruimte afgenomen. De proefpersonen waren niet op de hoogte van de inhoudelijke overeenkomsten tussen kennis-toets en probleem-toets. De instructie voor de kennis-items was gelijk aan die van de eerste studie waarin erop werd gewezen alleen die vragen met 'juist' of 'onjuist' te beantwoorden indien men zeker was van het antwoord. De probleem-items werden gepresenteerd met de volgende algemene instructie:

\begin{abstract}
"In de volgende 15 situaties worden problemen gepresenteerd wit het fysiotherapeutisch diagnostisch domem. Elk probleem begint met een opdracht. Lees deze goed. Deze opdrachten zijn niet altijd identiek. Geef aan de hand van de gegeven informatie een zo exact mogelijke oplossing. Enkele woorden of een $\mathrm{zin}$ is voldoende. Schrijf de oplossing bij het overeenkomstige nummer op het antwoordformulier."
\end{abstract}

\section{Analyse}

Op basis van de antwoord-sleutel die was geverifieerd door de experts werd een steekproef uit alle probleem-toetsen door twee beoordelaars, onafhankelijk van elkaar beoordeeld. De mate van overeenkomst tussen de twee beoordelaars bedroeg $96 \%$. Na overleg werden alle probleem-toetsen opnieuw beoordeeld door beide beoordelaars. De mate van overeenkomst beàroeg nu 98\%. Resterend overleg tussen beide beoordelaars leidde tot de definitieve score van de proefpersonen. De verzameling kennis-items werd op gebruikelijke wijze geanalyseerd waarbij voor elk item de score eveneens werd berekend op een dichotome schaal $(0=$ fout/geen antwoord, $1=$ goed). In de inleiding werd aangekondigd dat de kennisafhankelijkheid van probleemoplossen zou worden uitgedrukt in termen van kansen op een goede probleemoplossing indien de aan het probleem gerelateerde kennis-items goed waren beantwoord. Daarbij werd de veronderstelling geuit dat bij aanwezigheid van kennis een grote kans op een goede probleemoplossing bestaat en bij afwezigheid een grote kans op een foute probleemoplossing. Om deze veronderstelling te toetsen zijn de antwoorden op de kennis-items en de antwoorden op de daarmee gerelateerde probleem-items geanalyseerd in afzonderlijke kruistabellen. Omdat elk probleem-item gekoppeld was aan twee items uit de verzameling kennis-items konden beide voorspellingen 30 keer $(15 \times 2)$ getoetst worden. Een voorbeeld van deze analyse staat in Tabel 1. 
In Tabel 1 wordt als voorbeeld wan de totaal-analyse de resultaten gegeven van de afzonderlijke verbanden tussen de beide kennisitems en het probleem-item ${ }^{5}$. Uit deze beide analyses kan men afleiden dat het probleem door $22 \%$ van de proefpersonen goed werd opgelost. Indien de beantwoording van een kennis-item in sterke mate bepalend zou zijn voor de beantwoording van een probleem-item moeten de eerste en vierde cel van elke kruistabel ieder een proportie bevatten die dicht tegen 1.0 aanligt. In de gegeven voorbeelden is dit bijvoorbeeld in onvoldoende mate het geval. Met name de proportie goede antwoorden op het probleem-item, wanneer het ketunis-item juist beantwoord is, zijn erg laag. De verdelingen van de proefpersonen over de condities van de kennis-items werden als referentiepunten gehanteerd bij de berekening van de kansen op een goede of foute oplossing.

Tabel 1: Frequenties van, en kansen op, een foute of goede probleemoplossing onder de kenniscondities

probleem-item 1

fout:

fout

kennis-item $A$

goed

Totaal
$35(.70)$

$34(.89)$

69 goed

$15(.30)$

$4(.11)$

19
Totaal

$50(1.00)$

$38(1.00)$

88

problieem-item 1

kennis-item B

fout

fout

goed

Totaal
$54(.82)$

$15(.68)$

69 goed

Totaal

$12(.18)$

$7(.32)$

19
$66(1.00)$

88

"Deze items waren ook het voorbeeld in de bespreking van de meetinstrumenten. 
Bij het probleem-item uit Tabel 1 waren bij afwezigheid van kennis de kansen op een foute probleemoplossing hoger $(.70$ en .82$)$ dan de kansen op een goede probleemoplossing bij aanwezigheid van kennis (.11 en .32). Samenvattend kan dus voor dit probleem-item de conclusie getrokken worden dat op basis van het goed of fout beantwoorden van de gerelateerde kennis-items geen voorspelling mogelijk is ten aanzien van het goed of fout oplossen van het probleem. Voor de totaal-analyse werd van alle 30 kruistabellen de kans op een goede oplossing berekend bij aanwezigheid van kennis, uitgedrukt als $p\left(\text { goed }_{p} \text { lgoed }_{k}\right)^{6}$, en de kans op een fout antwoord bij afwezigheid wan kennis $p$ (fout $t_{p} \mid$ fout $\left._{k}\right)$.

Daarnaast werd in deze studie de sterkte van het verband tussen kennis en probleemoplossen uitgedrukt in een correlatiecoëfficiënt om de resultaten meer direct te kunnen vergelijken met de gegevens uit de eerste studie. De sterkte van de relatie tussen kennis en probleemoplossen werd uitgedrukt in een phi-coëfficiënt die kan worden vergeleken met de maximaal bereikbare phi-coëfficiënt ${ }^{?}$.

Overeenkomstig met de analyse van de instrumenten in studie 1 werd opnieuw met de toets van Anderson (Gustaffson, 1977) getoetst of er significante afwijkingen bestaan met het Rasch-model. Deze toetsing had de volgende resultaten: Verzameling kennis-items Chi-kwadraat: 32.32 , df $=$ $29, \mathrm{p}=.31$; Verzameling probleem-items Chi-kwadraat: 13.15 , df $=14, \mathrm{p}$ $=.51$. Beide sets van instrumenten voldoen dus aan de eisen van het Rasch-model omdat beide toetsingen geen significante afwijking opleverden.

\section{Resultaten en discussie}

In Tabel 2 staan de resultaten van de totale analyse van de verbanden tussen de kennis-items en de probleem-items. De kolom met de kop 'p(goeф). $\operatorname{goed}_{k}$ ) bevat de kansen op een goede oplossing bij een goede beantwoording van het kennis-item, de kolom met de kop 'p(fout $\mid$ fout $t_{k}$ )' bevat de kansen op een foute oplossing indien het kennis-item fout of niet beant-

${ }^{6} \mathrm{p}\left(\right.$ goed $_{\mathrm{p}}$ goed $_{\mathrm{k}}$ ) betekent dus de kans dat een probleem-item goed beantwoord word, gegeven het feit dat het bijbehorende kennis-item goed werd beantwoord.

${ }^{7}$ De gevonden phi-coëfficiënt moet geïnterpreteerd worden in het licht van een maximaal bereikbare phi-coëfficiënt. Ofschoon de phi-coëfficiènt theoretisch kan varièren tussen -1.0 en $1.0 \mathrm{zal}$ de gevonden phi-coëfficiënt slechts onder bepaalde condities deze extreme waarden kunnen bereiken. De reden voor deze beperkte phi-grootte ligt in de restricties die een eigenschap vormen van $2 \times 2$-kruistabellen: alleen als de 4 marginale totalen van beide variabelen een volstrekt gelijke verdeling bevatten is de extreme warde wan phi bereikbaar (Guilford \& Fruchter, 1973). 
woord werd. In de derde kolom staan de gevonden phi-coëfficiënten; de maximaal bereikbare phi-coëfficiënten staan in de vierde kolom.

Tabel 2: Resultaten van de analyse naar het verband tussen kennis en probleemoplossen op item-niveau

\begin{tabular}{|c|c|c|c|c|}
\hline Kennis-item & P(goed lgoed $\left._{k}\right)$ & $P\left(\right.$ fout $_{p} \mid$ fout $\left._{k}\right)$ & phi & phi-maximaal \\
\hline 1 & .11 & .70 & .23 & 60 \\
\hline 2 & .32 & .82 & .14 & 90 \\
\hline 3 & .59 & .59 & .17 & .71 \\
\hline 4 & .51 & .44 & .05 & .95 \\
\hline 5 & .31 & .88 & .22 & .44 \\
\hline 6 & .35 & .83 & .21 & .71 \\
\hline 7 & .88 & .10 & .04 & .21 \\
\hline 8 & .89 & .06 & .06 & .71 \\
\hline 9 & .44 & .61 & .04 & .58 \\
\hline 10 & .23 & .55 & .20 & .71 \\
\hline 11 & .17 & .84 & .01 & .60 \\
\hline 12 & .14 & .77 & .11 & .25 \\
\hline 13 & .36 & .68 & .05 & .67 \\
\hline 14 & .32 & .63 & .05 & .67 \\
\hline 15 & .59 & .31 & .10 & .98 \\
\hline 16 & .64 & .39 & .03 & .83 \\
\hline 17 & .18 & .94 & .18 & .55 \\
\hline 18 & .16 & .94 & .15 & .50 \\
\hline 19 & .84 & .54 & .35 & .55 \\
\hline 20 & .67 & .44 & .07 & .29 \\
\hline 21 & .51 & .48 & .01 & .79 \\
\hline 22 & .57 & .65 & .19 & .61 \\
\hline 23 & .60 & .80 & 30 & .48 \\
\hline 24 & .60 & .75 & .27 & .50 \\
\hline 25 & .78 & .21 & .02 & .48 \\
\hline 26 & .77 & .14 & .08 & .83 \\
\hline 27 & .12 & .95 & .12 & .28 \\
\hline 28 & .21 & .93 & .19 & .73 \\
\hline 29 & .63 & .44 & .05 & .41 \\
\hline \multirow[t]{3}{*}{30} & .64 & .49 & .13 & .78 \\
\hline & Gem. 0.47 & Gem. 0.60 & Gem. 0.14 & Gem. 0.60 \\
\hline & S.D. 0.24 & S.D. 0.30 & S.D. 0.11 & S.D. 0.20 \\
\hline
\end{tabular}


Inspectie van Tabel 2 geeft als totaal-indruk dat de aanwezigheid van kennis in betrekkelijk geringe mate een grote kans op een goede probleemoplossing oplevert. De gemiddelde $p\left(\right.$ goed $\left._{p} \operatorname{lgoed}_{k}\right)$ is 47 . Daarentegen is de kans op een foute probleemoplossing bij afwezigheid van kennis hoger: gemiddelde $p$ (fout ffout $_{k}$ ) is .60. Dit betekent dat beide rond de toevalswaarde variëren. De standaarddeviatie van $p\left(\right.$ goed $_{p}$ Igoed $\left._{k}\right)$ was gelijk aan .24 en de standaarddeviatie van $\mathrm{p}$ (fout f $_{\mathrm{p}}$ (out $\mathrm{t}_{\mathrm{k}}$ ) was .30 . De indruk die ontstond bij de bespreking van de analyse-voorbeelden in de vorige paragraf wordt bevestigd in de eind-resultaten: de antwoorden op de kennis-items zijn niet bepalend voor de juistheid van de probleemoplossing. De geringe sterkte van het verband tussen beide variabelen komt ook tot uitdrukking in de analyse van de phi-coëfficiënten. De gemiddelde waarde van de berekende phi-coëfficiënten bedroeg .14 tegen een gemiddelde waarde van de maximaal bereikbare phi-coëfficiënten van .61. Deze resultaten zijn over het geheel genomen nogal teleurstellend. Studie 2, die in dit hoofdstuk besproken werd, was opgezet om een mogelijke tekortkoming in de eerste studie te remediëren. De veronderstelling was dat de meting van probleemoplosvaardigheid, zoals geoperationaliseerd in studie 1, te zeer een aggregaat van uiteenlopende redeneerprocessen was en daarom niet voldoende sensitief om de rol van domeinspecifieke kennis tot uitdrukking te brengen. Daarom zou een meer gedetailleerde analyse, een analyse op item-niveau noodzakelijk zijn. Deze analyse is in dit hoofdstuk gepresenteerd en de conclusie kan niet anders luiden dan dat de rol van kennis bij het oplossen van problemen complexer is dan hier to nu toe is aangenomen. Zelfs de gedetailleerde vergelijking van de aan- of afwezigheid van precieze kennis met toepassing daarvan in probleem-elementen leverde niet het verband op dat verwacht mocht worden op basis van de studies die besproken werden in Hoofdstuk 1. De vraag is nu, hoe dit resultaat verklaard kan worden. Verondersteld zou kunnen worden dat tenminste twee verklaringen wellicht enige geldigheid zouden kunnen hebben:

1. De kennis is tijdens het oplossen fout gebruikt: er zijn redeneerfouten gemaakt bij het toepassen.

2. De kennis is tijdens het oplossen van een probleem niet gebruikt: hij was wel aanwezig maar was niet toegankelijk voor gebruik.

De eerste mogelijkheid, dat fouten zijn gemaakt bij het toepassen van de kennis, lijkt onwaarschijnlijk. Immers, de problemen waren kort en de kennis die moest worden toegepast was beperkt in omvang. In complexe problemen, bijvoorbeeld een complete casus, zal de kans op redeneerfouten hoger liggen doordat het moeilijk is grotere aantallen gegevens te combineren. Een meer voor de hand liggende verklaring is dus dat de kennis die toegepast had moeten worden, en die met de kennis-items werd gemeten, 
door een aantal proefpersonen wordt beheerst (kennis-item goed beantwoord) maar daarentegen niet wordt gebruikt (probleem-item fout opgelost); en omgekeerd.

Perfetto, Bransford en Franks (1983) en Bransford, Sherwood en Sturdevant (1987) onderzochten de toegankelijkheid van kennis in experimenten die overeenkomen met de opzet van de hier gerapporteerde studie. Ter illustratie van het begrip 'toegankelijkheid van kennis' worden het onderzoeksdesign en de resultaten van Perfetto et al. (1983) kort samengevat. Twee groepen proefpersonen kregen een aantal proposities gepresenteerd die na 20 seconden leestijd op waarheid beoordeeld moesten worden op een vijfpunts-schaal. Perfetto bewerkstelligde met deze taak dat de proefpersonen met de uitvoering van deze beoordelingstaak impliciet kennis verwierven ten aanzien van de inhoud van deze proposities. Na deze taak werden 3 minuten besteed aan testadministratieve aangelegenheden, alvorens werd aangekondigd dat een andere taak moest worden uitgevoerd: het oplossen van een aantal problemen. Deze problemen bestonden uit een korte probleemschets, afgesloten met een open vraag. Bijwoorbeeld: "Uriah Fuller, the famous Israeli superpsychic can tell you the score of any baseballgame before the game starts. What is his secret?" De oplossing van dit probleem kan worden gevonden in een propositie uit de voorafgaande beoordelingstaak: "Before any game is played, there is no score." Deze propositie is in algemene termen geformuleerd maar is goed toepasbaar in de voorgaande probleemtekst. Voor de oplossing van het probleem kregen de proefpersonen 40 seconden. De experimentele groep kreeg een hint door de mededeling dat de inhoud van de voorafgaande beoordelingstaak gebruikt kon worden in de probleemoplostaak, de controle-groep kreeg deze hint niet. Tenslotte bevatte het design nog een basis-controle-groep die alleen de probleemoplostaak moesten uitvoeren zonder kennisverwerving. In Tabel 3 staan de gemiddelde percentages goede oplossingen per groep.

Tabel 3: Percentages goede probleemoplossingen onder verschillende condities (Perfetto et al., 1983)

geen kennisverwerving $\quad 19$

wel kennisverwerving, geen hint 29

wel kennisverwerving, hint $\quad 54$

Perfetto trok uit deze gegevens de conclusie dat de voorafgegeven aanwijzing om de inhoud van de beoordelingstaak te gebruiken in belangrijke 
mate bepalend was voor het gebruik van kennis. Uit de analyse van de antwoorden op een aansluitende vragenlijst bleek namelijk dat geen van de proefpersonen uit de niet-geïnformeerde groep spontaan gebruik maakte van de kennis die impliciet was verworven in de beoordelingstaak.

Het design van Perfetto vertoont veel overeenkomsten met de hier gerapporteerde studie. Ook de fysiotherapie-studenten kregen in de verzameling kennis-items voorafgaande aan de presentatie van de probleem-items een aantal proposities gepresenteerd die moesten worden beoordeeld. Bij de presentatie van de probleem-items werd geen aanwijzing gegeven de inhoud van de kennis-items te gebruiken. In de bespreking van de in deze studie gebruikte meetinstrumenten werd een voorbeeld gegeven van een probleemitem zoals die werd gepresenteerd aan de proefpersonen. Eveneens werd een voorbeeld gegeven van de bij dit probleem-item behorende kennisitems. In deze kennis-items was in beide gevallen sprake van een concept 'painful-arc' dat als zodanig niet in het probleem-item voorkwam. De proefpersonen moesten de gegevens uit de probleemtekst combineren en interpreteren tot het concept 'painful-arc'. Na activatie van dit concept kan dit worden betrokken in een redenering zoals verwoord in de kennis-items. Dit is de karakteristieke moeilijkheid van probleemoplossen: een slecht gedefinieerd probleem moet worden getransformeerd tot een goed gedefinieerd probleem waarop vervolgens de door de transformatie geactiveerde kennis kan worden toegepast. Proefpersonen die beschikten over de juiste kennis met betrekking tot het concept 'painful-arc' in kwestie hebben wellicht gefaald in de herkenning van de in de tekst opgenomen symptomen. Het nietgebruiken van kennis is in deze opvatting niet het falen van een 'zoekopdracht' naar toepasbare kennis in het geheugen maar het achterwege blijven van activatie van aanwezige en toepasbare kennis.

Het percentage goede oplossingen in het onderzoek van Perfetto van de groep zonder hint is significant lager dan het percentage goede oplossingen van de groep die wel de aanwijzing kreeg de verworven kennis te gebruiken. Het gericht activeren van voorkennis door de aanreiking van de hint is de vermoedelijke oorzaak van de stijging van het percentage goede oplossingen bij de experimentele groep in het onderzoek van Perfetto. In de studie die in het volgende hoofdstuk besproken zal worden is de activatie van voorkennis het uitgangspunt van een experiment met als doel de probleemoplosvaardigheid te verhogen indien men beschikt over de probleemrelevante kennis. 


\section{.}




\section{HOOFDSTUK 4}

\section{Activatie van kennis bij het oplossen van problemen}

\section{Inleiding}

In dit hoofdstuk wordt verslag gedaan van de resultaten van een experiment. Dit experiment was gericht op het activeren van probleemrelevante kennis tijdens het probleemoplossen. De basis voor dit experiment vormen de resultaten van de studies in Hoofdstuk 2 en 3. Daarin werd duidelijk dat proefpersonen kennis niet leken toe te passen in een probleemtaak, ofschoon deze proefpersonen wel over deze kennis beschikten.

Voor een juiste interpretatie van de strekking van dit experiment gaan we opnieuw terug naar het proces van informatieverwerking tijdens het probleemoplossen. Er bestaat eenstemmigheid over de karakterisering van het diagnostisch proces als hypothetico-deductief. (Elstein, Shulman \& Sprafka 1978; Barrows \& Tamblyn, 1980 e.a.). Daarentegen bestaat er geen eenstemmigheid over de aard van de informatie die geactiveerd wordt bij het tot stand komen van diagnostische hypothesen; evenmin bestaat er eenstemmigheid over het moment waarop de diagnostische hypothesen worden gegenereerd. Bij de bespreking van het informatie-theoretisch model van probleemoplossen in Hoofdstuk 1 werd reeds aandacht geschonken aan de waarneming van probleem-informatie door de probleemoplosser in de initiele fase van het denkproces. Gale \& Marsden $(1982,1983)$ geven een nauwkeurige beschrijving van de beginactiviteiten van de probleemoplosser met als uitgangspunt dat de kwaliteit van de diagnostiek in belangrijke mate wordt bepaald door de kwaliteit van de beginfase van het denkproces. Uit een inhouds-analyse van op video geregistreerde anamnese-gesprekken in een arts-patiënt contact werden uit de commentaren van de betrokkenen (die achteraf geïnterviewd werden) drie verschillende denkprocessen afgeleid: 
1. Pre-diagnostische interpretatie: en globale probleemdefiniëring die nog niet specifiek genoeg is voor een waarschijnlijkheidsdiagnose (bijvoorbeeld: "Er is iets aan de hand met de lever").

2. Diagnostische interpretatie: een meer specifieke probleemdefiniëring, basis voor een waarschijnlijkheidsdiagnose waarin een pathofysiologisch proces wordt aangegeven. (Bijvoorbeeld: "Ik dacht aan een carcinoom van de pancreas").

3. Behoefte aan riadere informatie, onafhankelijk van pre-diagnostische en diagnostische interpretatie. (Bijvoorbeeld: "Ik wilde weten wat ze bedoelde met ...").

Gale en Marsden (1982) constateerden dat, ongeacht de ervaring van de betrokkenen, er veelvuldig sprake was van pre-diagnostische interpretatie, dat er minder sprake was van diagnostische interpretatie en dat slechts in een enkel geval er sprake was van een behoefte aan aanvullende informatie door de betrokkenen zonder dat die geleid werd door een diagnose. Gale en Marsden (1982) postuleren dat twee psychologische activiteiten een rol spelen in het diagnostisch denkproces: structurering en extrapolatie. Structurering van de waargenomen probleeminformatie (dat wil zeggen: opbouw van een probleemrepresentatie) wordt gevolgd door het actief worden, of 'activatie', van concepten die geen deel uit maken van de 'objectieve' probleeminformatie (bijvoorbeeld omdat ze niet door de patiënt genoemd zijn). Uit het onderzoek van Gale en Marsden blijkt dus dat herstructurering van de gegeven probleeminformatie een belangrijke cognitieve activiteit is in de beginfase van een diagnostisch denkproces. De representatie van het probleem, ook al heeft deze nog een voorlopig karakter, activeert de benodigde kennis die moet worden gebruikt in het vervolg van het denkproces. In het experiment dat hierna besproken wordt, zal de proefpersonen hulp worden gegeven om de probleeminformatie zodanig te structureren dat een juiste probleemrepresentatie wordt opgebouwd. In termen van Gale en Marsden is het experiment gericht op het ondersteunen bij de pre-diagnostische interpretatie van informatie waarbij een zekere mate van sturing wordt beoogd naar een juiste waarschijnlijkheidsdiagnose. De psychologische activiteit die centraal staat in de experimentele manipulatie is het structureren van informatie, de extrapolatie van concepten (activatie van beschikbare kennis) wordt hier beschouwd als de consequentie daarvan. De proefpersonen in de experimentele groep kregen een analogie aangeboden die hen kon helpen bij de structurering van informatie. Voorafgaande aan de bespreking van de gehanteerde methode wordt in de volgende paragraaf een theoretische onderbouwing gegeven van de opzet van het experiment en worden enkele resultaten van vergelijkbare experimenten besproken die als uitgangspunt dienden voor de opzet van het hier te rapporteren experiment. 


\section{Probleemherkenning en analogie}

Gick \& Holyoak $(1983,1985)$ onderzochten het spontaan gebruik van eerder verworven kennis in het oplossen van nieuwe problemen. In hun experimenten probeerden zij systematisch door variatie van de experimentele condities het percentage goede oplossingen van eenzelfde probleem onder hun proefpersonen te verhogen. Daarbij werden de verschillen in effectiviteit van de verschillende experimentele condities met elkaar vergeleken. Het doelprobleem dat de proefpersonen (leerlingen uit het secundair onderwijs) werd voorgelegd bestond uit de tekst van Tabel 1 :

\section{Tabel 1: Tekst van 'stralingsprobleem' (Gick en Holyoak, 1983)}

Suppose you are a doctor faced with a patient who has a malignant tumor in his stomach. It is impossible to operate on the patient, but unless the tumor is destroyed the patient will die. There is a kind of ray that can be used to destroy the tumor. If the rays reach the rumor all at once at a sufficiently high intensity, the tumor will be destroyed. Unfortunately, at this intensity the healthy tissue that the rays pass through on the way to the tumor will also be destroyed. At lower intensities the rays are harmless to healthy tissue, but they will not affect the tumor either. What type of procedure might be used to destroy the tumor with the rays, and at the same time awoid destroying the healthy tissule?

Dit probleem is bekend als het klassieke 'stralingsprobleem' van Duncker (1945). De oplossing van het probleem is de tumor gelijktijdig te bestralen vanuit verschillende richtingen. Daarbij moet aan elke stralingsbron afzonderlijk een lage intensiteit gegeven worden. Het cumulatieve effect van bestraling vanuit verschillende richtingen resulteert in een straling met voldoende intensiteit om de tumor te vernietigen zonder daarbij echter het gezonde weefsel te beschadigen.

In verschillende onderzoekingen vonden Gick en Holyoak dat ongeveer $10 \%$ van hun proefpersonen het probleem spontaan correct oplosten. Dit basis-percentage van goede oplossingen in deze controlegroepen probeerden zij nu te verhogen met de volgende experimentele manipulaties:

1. Analogie: Onder deze conditie kregen de proefpersonen uit de experimentele groep, voorafgaande aan de presentatie van het probleem, een tekst te lezen met de opdracht deze samen te vatten. Deze tekst bevatte een beschrijving van een analoog probleem èn de bijbehorende correcte oplossing. In een tekst met de titel 'De generaal' bijvoorbeeld wordt beschreven hoe 
een generaal een fort wil veroveren dat in het midden van een land ligt. Vele wegen leiden naar het fort. Alle wegen zijn ondermijnd zodat alleen kleine groepen mensen veilig de weg kunnen gebruiken, bij een grote groep mensen zouden de mijnen ontploffen. Een grootscheepse directe aanval is dus op voorhand onmogelijk. De generaal kiest echter de volgende oplossing: het leger wordt verdeeld in kleine groepen en over verschillende wegen naar het fort gestuurd. Als de soldaten tegelijkertijd bij het fort aankomen kan het fort veroverd worden. Deze oplossing noemen Gick en Holyoak de 'convergentie-oplossing".

2. Analogie met diagram: Onder deze conditie werd de analogie-tekst aangevuld met een grafische toelichting over het gekozen oplossingsprincipe.

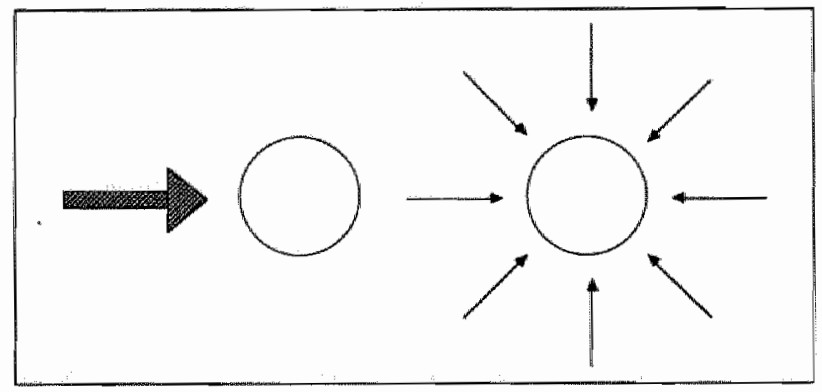

3. Analogie met toelichting: Onder deze conditie werd de analogie-tekst aangevuld met een korte verbale toelichting over het gekozen oplossingsprincipe met dezelfde strekking als de grafische toelichting (sterkte, verschillende richtingen, samenkomen, etc.)

4. Twee analogie-teksten met schema-inductie: Onder deze conditie kregen de proefpersonen twee teksten te bestuderen met als opdracht de overeenkomsten tussen beide teksten op te schrijven. In deze conditie is het niet de bedoeling dat een letterlijke tekst de analogie-basis is maar een tekst-onafhankelijk 'convergentie-schema' dat de proefpersonen op basis van twee verschillende analogieèn moesten construeren. De analogie-teksten die de basis zijn voor dit schema konden meer of minder direct verwant zijn: er werd onderscheid gemaakt tussen domeingebonden en domeinonafhankelijke analogieën. Naast de tekst van 'De generalal' werd een tekst gepresenteerd over een militair die een eiland in een meer wilde veroveren via kleine bruggen (domeingebonden). Minder 'letterlijke' overeenkomsten vertoonde echter een tekst over de legendarische Red Adair die een brand bij een oliebron slechts kon blussen als de vuurhaard tegelijkertijd van verschillende kanten met schuim werd bespoten (domeinonafhankelijk).

De effecten van deze afzonderlijk gehanteerde primaire condities werden met elkaar vergeleken. Binnen elke conditie was er sprake van een secundaire experimentele manipulatie, namelijk de expliciete hint de gepresen- 
teerde analogie te gebruiken bij de probleemoplossing. Gick en Holyoak rapporteerden dus drie uitkomsten: het totaal-percentage proefpersonen dat in een bepaalde experimentele conditie de goede oplossing vond, onderscheiden naar groepen die de oplossing voorafgaande aan de verstrekking van de hint vonden en diegenen die het probleem pas na de hint correct oplosten. Uit de reeks experimenten van Gick en Holyoak worden hier twee resultaten geciteerd (Tabellen 2 en 3):

Tabel 2: Percentages proefpersonen met convergentie-oplossing (Gick en Holyoak, 1983, p. 19)

Voor hint Na hint Total N

$\begin{array}{lcccc}\text { Analogie } & 40 & 36 & 76 & 25 \\ \text { Analogie + diagram } & 23 & 58 & 81 & 26 \\ \text { Diagram } & 7 & 60 & 67 & 15\end{array}$

In Tabel 2 is te zien dat na het kennisnemen van eén goede oplossing slechts $40 \%$ van de proefpersonen deze kennis spontaan toepassen (voor hint) in een nieuwe probleemtaak. Na de hint verdubbelt dit percentage goede oplossingen. Het percentage stijgt nog aanzienlijk indien de proefpersonen de opdracht krijgen twee teksten te lezen en daarvan de overeenkomsten op te schrijven. In Tabel 3 zijn de percentages goede oplossingen weergegeven waarin de experimentele conditie uit twee analogie-teksten bestond:

Tabel 3: Percentages proefpersonen met convergentie-oplossing nadat twee analogieën zijn voorgelegd (Gick en Holyoak, 1983, p. 29).

\begin{tabular}{lcccc}
\hline & Voor hint & Na hint & Totaal & N \\
& & & & \\
Domeingeb. analogie + diagram & 61 & 33 & 94 & 48 \\
Domeinonafh. analogie + diagram & 53 & 37 & 90 & 51 \\
Domeingeb. analogie zonder diagram & 40 & 40 & 79 & 43 \\
Domeinonafh. analogie zonder diagram & 34 & 45 & 79 & 47 \\
\end{tabular}


In deze tabel is te zien dat maximaal $61 \%$ van de proefpersonen de verworven kernis gebruiken. In vergelijking met Tabel 2 is het spontane gebruik van kennis (voor de aanwijzing) gestegen van $40 \%$ naar $61 \%$. Dit effect is van belang voor onze vraagstelling. De basis-controlegroep zonder analogieèn van Gick en Holyoak produceerde slechts $10 \%$ goede oplossingen. Dat betekent dat het stralingsprobleem een moeilijk probleem is dat zonder specifieke voorkennis moeilijk oplosbaar is. Is de kennis wel aanwezig, dan kan 94\% van de proefpersonen het probleem oplossen wanneer die kennis door middel van een aanwijzing wordt geactiveerd en toegepast op het nieuwe probleem. 61\% van deze oorspronkelijke groep gebruikt spontaan deze kennis. Indien we terugkijken naar de resultaten uit de voorgaande studie die beschreven is in Hoofdstuk 3 was er ook in deze studie sprake van moeilijke problemen met een hoge kans op een foute oplossing zonder specifieke kennis en een vergelijkbaar lage kans op een goede oplossing indien de kennis wel aanwezig is.

De rol van analogieën in het leerproces en de betekenis hiervan voor het vermogen eerder verworven kennis ook werkelijk toe te passen in het oplossen van problemen is door velen onderzocht. Een terugkerend discussiepunt hierbij is in welke mate het 'zien' van een analogie, en om deze vervolgens toe te passen, een kenmerk is van (domein-onafhankelijke) intelligentie of van een verworven (domein-afhankelijke) vaardigheid. Sternberg (1977) is van mening dat analogie-problemen ongeacht vorm, inhoud en moeilijkheidsgraad consistent worden benaderd en dat dit een kenmerk is van intelligent handelen. Holyoak (1984) relativeert deze opvatting van Stemberg door er op te wijzen dat er overeenkomsten en verschillen bestaan tussen analogie-taken uit een intelligentietest en de analogie-taken zoals hierboven beschreven. De vorm waarin de analogie-vergelijking zich uiteindelijk manifesteert kan dezelfde zijn, bijvoorbeeld $A: B: C: D$. Het verschil echter tussen een item uit een intelligentie-test en het oplossen van een probleem, ook wel creatief probleemoplossen genoemd, is dat een individu in het oplossen van een probleern de samenstellende delen van de analogie-vergelijking (A:B en C:D) zelfstandig moet kiezen en evalueren op bruikbaarheid. Daarentegen wordt in een intelligentie-test de vergelijking als zodanig direct gepresenteerd. Holyoak wijst er in dit verband op dat er een relatie bestaat tussen de vaardigheid in het denken in analogieèn en expertise in probleemoplossen. Domein-specifieke heuristieken bouwen voort op domein-onafhankelijke heuristieken. In probleemoplossen betekent het gebruik van een analogie de toepassing van een algemene heuristiek waarvan de mate van succes bepaald wordt door de expertise in het specifieke domein waarbinnen de analogie van kracht is. 
Een analogie-schema kan een min of meer abstract karakter hebben. Diverse auteurs veronderstellen dat er een verband bestaat tussen de vaardigheid in het gebruiken van abstracte analogie-schemata en de mate van expertise in een specifiek domein. Beginners nemen relatief oppervlakkige kenmerken van een probleem waar en experts meer abstracte causale relaties (Larkin, McDermott, Simon \& Simon, 1980; Chi, Feltovich \& Glaser 1981). Deze expertise is het resultaat van een langdurig voorafgaand proces van herstructurering van reeds eerder verworven kennis (Rumelhart \& Norman, 1981). Het uitgangspunt dat kennis gestructureerd is "opgeslagen' is herkenbaar in de onderzoeken van Gentner \& Gentner (1983), Gentner (1983) en Gentner \& Toupin (1986) naar de structurele kenmerken van analogisch denken. In het gebruik van een schematische analogie worden niet de attributen van een object met elkaar vergeleken maar de relaties tussen objecten. Deze structurele vergelijking wordt gestimuleerd indien de analogie twee eigenschappen bezit: transparantie en systematiek. Onder transparantie wordt de mate van directe overeenkomt tussen basis- en doeldomein verstaan. Dit komt tot uitdrukking in de aanwezigheid, in meer of mindere mate, van exact dezelfde objecten in beide domeinen. Onder systematiek wordt verstaan de mate waarin de relaties tussen de objecten uit de schematische analogie vergelijkbaar zijn. In de experimenten van Gick en Holyoak hadden beide principes een positief effect op toegankelijkheid en gebruik van de analogie. Door twee teksten aan te bieden met de opdracht daarvan de overeenkomsten te beschrijven (de 'convergentieschema'-inductie) bewerkstelligden Gick en Holyoak dat hun proefpersonen de onderlinge relaties tussen de objecten uit beide teksten expliciet in beschouwing namen (systematiek van de analogie). Het percentage goede oplossingen dat spontaan tot stand kwam op basis van het gebruik van voorkennis was dus hoger indien de voorkennis door middel van de opdracht tot schema-inductie gestructureerd was verworven (zie Tabellen 2 en 3). Bovendien was er ook sprake van een positief, weliswaar kleiner, effect met betrekking tot de transparantie van de analogie. In Tabel 3 zien we dat het percentage spontaan geproduceerde goede oplossingen hoger was indien er sprake was van een analogie-beschrijving op basis van twee teksten uit hetzelfde domein (directe overeenkomst in objecten, minder abstract schema).

Samengevat: Uit de experimenten van Gick en Holyoak wordt duidelijk dat indien de toepasbare kennis is verworven in een gestructureerde context (inductie van convergentie-schema over twee analogie-teksten) de toegang tot deze kennis bij de oplossing van nieuwe problemen in stijgende lijn wordt bevorderd. In een controle op hun experimentele effecten (de beschrijving van de overeenkomst tussen beide analogie-teksten door de proefpersonen werd ook door de onderzoekers ingenomen en geanalyseerd) 
constateerden Gick en Holyoak dat de kwaliteit van de geproduceerde schema's in sterke mate bepalend was voor het wel of niet vinden van de convergentie-oplossing. Het ter beschikking hebben van een transparante en systematische analogie kan dus de aanwezige kennis activeren tijdens het oplossen van een nieuw probleem. In het hiema te bespreken experiment zullen deze bevindingen worden getest in de context van het oplossen van fysiotherapie-problemen.

In de inleiding op deze studie naar activatie van kennis werd de aandacht gericht op de twee psychologische processen die een rol spelen in de analyse van een probleem en het daarop volgende denkproces: structurering en extrapolatie. Structurering van waargenomen probleeminformatie leidt tot extrapolatie: het denken met concepten die niet zijn opgenomen in de oorspronkelijke probleem-informatie maar worden 'toegevoegd' aan het denkproces tengevolge van activatie van kennis. Op basis van de experimenten van Gick en Holyoak kan worden verondersteld dat de activatie en het gebruik van kennis in het denkproces bevorderd kan worden door middel van het aanreiken van een analogie én de aanwijzing deze analogie te gebruiken in de oplossing van het probleem. Let wel, onze primaire interesse is de beantwoording van de vraag in welke mate en op welke wijze relevante domeinkennis een rol speelt bij het oplossen van problemen. De methodologie ontwikkeld door Gick en Holyoak geeft de mogelijkheid na te gaan in hoeverre het activatiefenomeen intermedieert tussen de aanwezigheid van kennis en het toepassen van deze kennis. In een speciaal daartoe ingericht analogie-experiment zal de volgende hypothese getoetst worden: Onder de voorwaarde dat de probleemrelevante kennis beschikbaar is zal een individu het probleem beter oplossen indien deze kennis is geactiveerd.

\section{Studie 3: Beïnvloeding van probleemoplosvaardigheid door activatie van kennis; verslag van een experiment}

\section{Methode}

\section{Proefpersonen}

Voor deze studie werd de medewerking verkregen van een groot gedeelte van dezelfde groep proefpersonen die aan de voorgatande studies deelnamen: 72 derdejaars studenten fysiotherapie, afkomstig van drie verschillende opleidingen. De theoretische vooropleiding van deze studenten ter voorbereiding op de praktijkleerperiode was afgesloten op het moment van onderzoek. Deelname aan het onderzoek geschiedde op vrijwillige basis en werd 
beloond met een kleine vergoeding. Uit een controle-analyse op basis van de studie-resultaten werd geconcludeerd dat er geen verschillen bestonden tussen de deelnemende selectie en de jaargroepen van waaruit zij afkomstig waren.

\section{Meetinstrumenten}

Voor het meten van de probleemoplosvaardigheid werd een casus-toets gebruikt in dezelfde vorm als in de eerste studie. De casus-toets (titel: Lumbago) bestond uit een boekje van 11 pagina's op A4-formaat waarin alle gegevens waren opgenomen die relevant zijn voor een vooraf scherp gedefinieerde fysiotherapeutische diagnose. De gegevens in de casus-toets werden gepresenteerd in een vijftal rubrieken die overeenstemmen met een standaard fysiotherapeutisch onderzoek. ${ }^{1}$ Ook deze casus werd voorgelegd aan 20 ervaren fysiotherapeuten met het verzoek om te beoordelen of de opgenomen probleem-informatie aansloot bij de voorgestelde diagnose-toetssleutel. Alle opmerkingen zijn verwerkt in de definitieve toets.

Overeenkomstig de voorgaande studies is ook in deze studie vanuit de casus-toets, via dezelfde procedure, een parallelle verzameling van kennisitems samengesteld van 15 items. In tegenstelling tot Studie 1, maar in overeenstemming met de aanpak in Studie 2 was de inhoud van de verzameling kennis-items volledig gematched met de diagnose-sleutel. Op basis van deze matching kan een analyse op de toetsresultaten worden uitgevoerd die vergelijkbaar is met die van Studie 2.

Voor de experimentele groep werden naast de kennistoets en de casustoets een tweetal studie-teksten samengesteld voor de activatie van voorkennis met behulp van een analogie. De casustoets had als onderwerp 'lumbago'. Onder lumbago (spit) verstaat men een doorgaans acuut optredende hevige pijn in de lendestreek die in hevigheid toeneemt bij elke beweging van de rug en die de patiènt met een in dwangstand sterk gefixeerde wervelkolom noodzaakt te blijven zitten of liggen. De aanval pleegt na enige dagen, hoogstens een week, af te zakken maar toont een sterke neiging tot herhaling op een later tijdstip (Kingma \& Dokter, 1985). De diagnose lumbago wordt gesteld aan de hand van het symptoom pijn. In de klinische praktijk wordt de diagnose gehanteerd om aan te geven dat er sprake is van acuut optredende rugpijn met onbegrepen oorzaak.

Alle relevante voorkennis die moest worden gebruikt en bij adequate toepassing zou leiden naar een goed geformuleerde diagnose was geformuleerd in de 15 items van de kennistoets. De veronderstelling was, dat, in-

' Zie voor een uitwoeriger beschrijving van deze toetsvorm Hoofdstuk 2. 
dien in de lumbago-casus de gegeven probleem-informatie juist zou worden gestructureerd de relevante voorkennis, indien aanwezig, zou worden geactiveerd. In de analogie moest derhallve de structurering van de relevante informatie benadrukt worden met het doel, om bij gebruik van de analogie, het door Gale en Marsden (1983) onderscheiden proces van extrapolatie te bevorderen. Indien in de lumbago-casus de symptomen zodanig gestructureerd worden dat de etiologie van de klacht van de patiënt helder wordt, zijn de condities voor kennisactivatie en diagnose-formulering optimaal. In de vormgeving van het instrument voor de activatie van voorkennis door middel van een analogie is uitgegaan van de combinatie van condities die in de experimenten wan Gick en Holyoak de sterkste effecten hadden:

- de proefpersonen kregen twee analogie-teksten aangeboden met de opdracht daarvan de overeenkomsten te beschrijven. Door middel van een herhaling van de objecten in de analogie-teksten wordt de transparantie van de analogie bevorderd.

- beide analogie-teksten werden uitgebreid met een grafische weergave van de structuur van de genoemde concepten. In de grafische presentatie wordt de systematiek in de analogie benadrukt. Naast de besproken experimenten van Gick en Holyoak bestaat er ruime empirische ondersteuning voor de positieve leereffecten van visualisatie (schematisering) van leerstof in teksten (Beveridge \& Parkins, 1987; Hayes, 1986; Gick, 1985; Curtis \& Reigeluth, 1984; Royer \& Cable, 1976 en Rigney \& Lutz, 1976).

Beide studieteksten èn grafische uitbreiding werden gepresenteerd zoals weergegeven is in Tabellen 4 en 5 .

Beide analogie-teksten benadrukken de etiologie van een complex klachtenpatroon. Als iemand inzicht heeft in de etiologie van een klacht zal men beter in staat zijn het symptomencomplex te begrijpen. In beide studieteksten wordt een beeld geschetst van een chronisch degeneratief (slijtage)proces. Een dergelijk proces gaat gepaard met klachten in de vorm van pijn bij bepaalde bewegingen, ochtendstijfheid, startstijfheid, 'op slot zitten" van bewegingen met daarbij periodes (weken, maanden) met relatief weinig of geen klachten. Dit degeneratief proces beïvloedt ook structuren waar eigenlijk niets aan de hand is. Echter, gewrichten worden meer belast om pijnlijke structuren te ontlasten. Dit beînvloedt weer de houding en beweging van de patiènt. In reactie hierop kunnen overbelastingsklachten van gewrichten en spieren worden uitgelokt. Bovendien is er in een degeneratief proces een risico dat het klachtenbeeld acuut verandert omdat structuren loslaten uit de gedegenereerde weefsels, bijvoorbeeld kraakbeen- en botfragmenten. Het klachtenbeeld verandert hierdoor plotseling. 


\section{Studietekst 1}

De typische symptomen wan een emstige heuparthrose zijn bekend bij alle fysiotherapeuten. Deze zijn onder andere: ochtendstijfheid, startpijn, crepitaties, uitstralende pijn aan binnenzijde bovenbeen en knie, röntgenologische afwijkingen, bewegingsbeperkingen volgens het kapsulaire patroon.

Dit typische beeld kan acuut verandieren als uit het arthrotisch gewrichtsgedeelte een kraakbeen- of botfragment loslat. Dit fragment kan onder invloed van belasting gaan inklemmen. Deze inklemming veroorzaakt stekende pijn, gevoel van instabiliteit en een bewegingsbeperking van de exorotatie.

De arthrose en het corpus liberum kunnen ook secundair klachten veroorzaken op afstand omdat statiek en bewegen beinvloed worden door de primaire oorzaak. Zo kan de lumbale wervelkolom een scoliose gaan vertonen en de heterolaterale heup tijdens het gaan overbelast worden.

Het symptomencomplex van heuparthrose, corpus liberum en klachten op afstand worden door de patiënt als én geheel gepresenteerd.

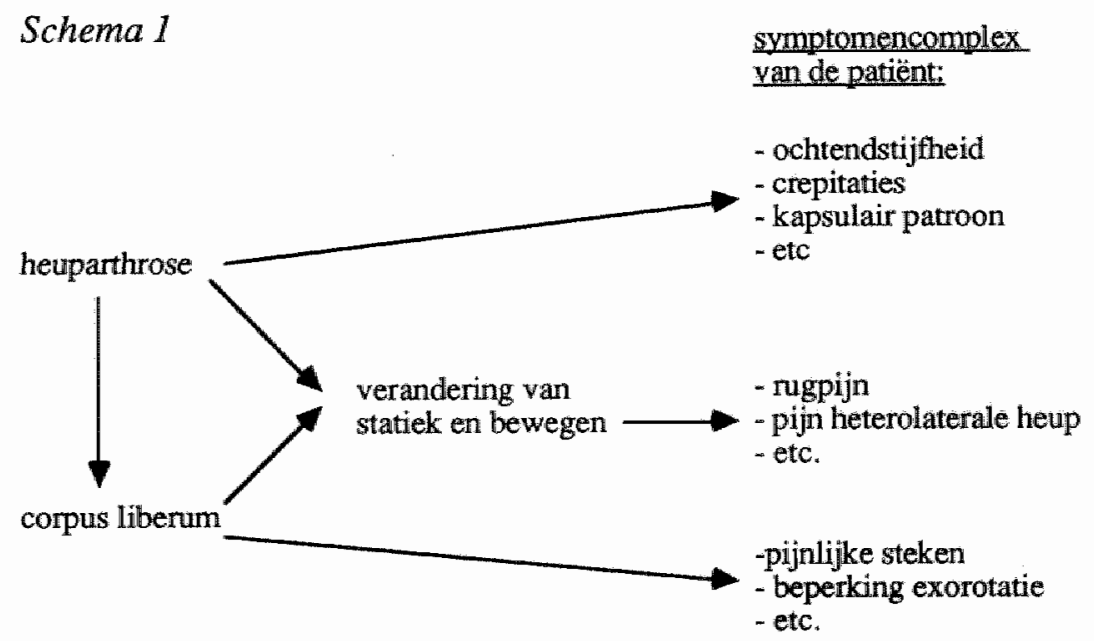




\section{Studietekst 2}

Degeneratie van een cervicale discus intervertebralis kan een chronisch lokaal cervicaal syndroom veroorzaken. Dit syndroom kan gepaard gaan met de volgende symptomen: pijn die door de patiênt wordt aangegeven in de spieren tussen de schouderbladen, churonische pijn met pijnvrije intervallen van enige weken tot maanden, pijnuitstraling naar ér schouder en het dorsalle deel wan de bovenarm, bewegingsbeperking naar eén richting en röntgenologische afwijkingen.

Deze kllachten kunnen plotseling weranderen als weefsel van de gedegenereerde discus in de richting wan het foramen vertebrale gaat uitstulpen. Karakteristiek kunnen nu worden o.a.: een dwangstand wan het hoofd, witstralende pijnen in de arm binnen het dernatoom wan het betreffende segment en sensibiliteitsstoomissen. Dit symptomencomplex noemt men ook wel een cervicobrachiaalsyndroom.

De discusdegeneratie en de opgetreden complicatie kunnen ook consequenties hebben voor naburige gewrichten. Door de versmalling van de tussenwervelschijf zullen de corpora vertebrae elkaar naderen. Dit heeft tot gevolg dat de gewrichtswlakiken van de intervertebralgewrichten ork dichter bij elkaar komen. Hierdoor worden de gewrichtswlakken dyscongruent en bepaalde gedeelten van cle gewrichten samengedrukt. De begeleidende klachten van dit mechanisme $\mathrm{kan}$ het herleiden van een aanwezig cervicobrachiaal syndroom ingewikkeld maken.

\section{Schema 2}

symptomencomplex. van de patiènt:

- chronische pijn

- pijnvrije intervallen

- pijnuitstraling naar

én schouder

- etc.

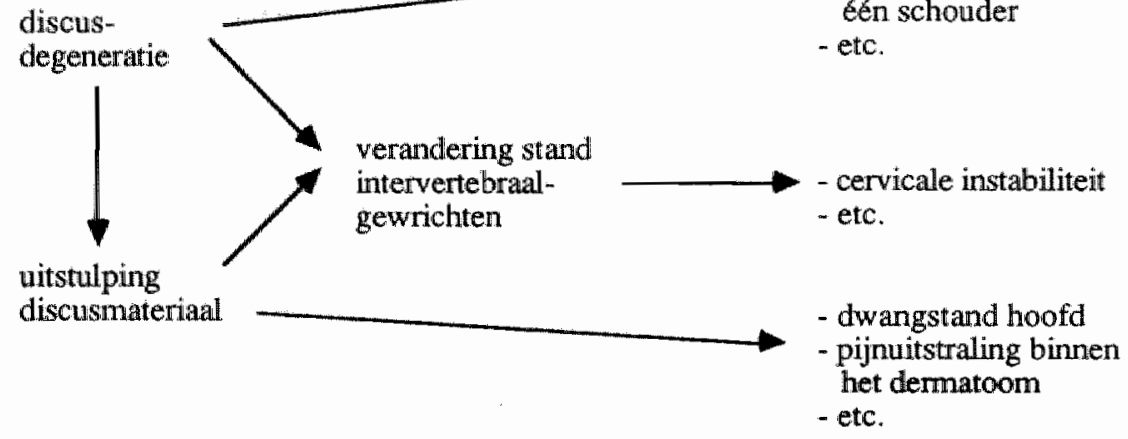


Het oorspronkelijke degeneratieve symptomencomplex verdwijnt echter niet maar zal overschaduwd worden door het acute beeld. De invloed op houding en beweging is wederom aanwezig. De patiênt zoekt daarbij de weg van de minste pijn. Samengevat: door middel van een goede structurering van symptomen kan men een onderscheid maken tussen chronische en acute symptomen. Dit is de kern van de casus, en de beide analogieteksten zijn expliciet gericht op een ordening van acute en chronische symptomen.

De wijze waarop de casus en de bijbehorende diagnose-antwoordsleutel samenhangen met de analogie in beide teksten is de volgende. In de casus wordt een man gepresenteerd met chronische lage rugklachten. Röntgenologisch zijn versmallingen van tussenwervelschijven aangetoond. Er is sprake van een degeneratief proces. De begeleidende klachten zijn bekend als het pseudo-radiculair syndroom (item uit de diagnose-sleutel). Dit chronische klachtenpatroon is acuut veranderd. De oorzaak hiervan is een protrusie (uitstulping) (item diagnose-sleutel) van de tussenwervelschijf tussen de vierde en vijfde lendewervel (item diagnose-sleutel). Deze protrusie drukt tegen bepaalde zenuwen afkomstig uit het ruggemerg. De begeleidende klachten hiervan zijn bekend als het radiculair syndroom (item uit diagnosesleutel). Dit acute en chronische klachtenpatroon beinvloedt houding en beweging. Er is sprake van een blokkering van één van de sacro-iliacaal gewrichten (item diagnose-sleutel). De lendewervels passen niet meer goed op elkaar en zijn instabiel (item diagnose-sleutel), en veroorzaken een ontstekingsreactie van intervertebraalgewrichten (item diagnose-sleutel).

Indien men op basis van de gegevens uit de casus een soortgelijk schema zou produceren als is toegevoegd aan de analogie-teksten, zou dit schema met betrekking tot de lumbago de vorm kunnen hebben zoals:

\section{Figuur 1: Analoog schema symptomencomplex lumbago-casus}

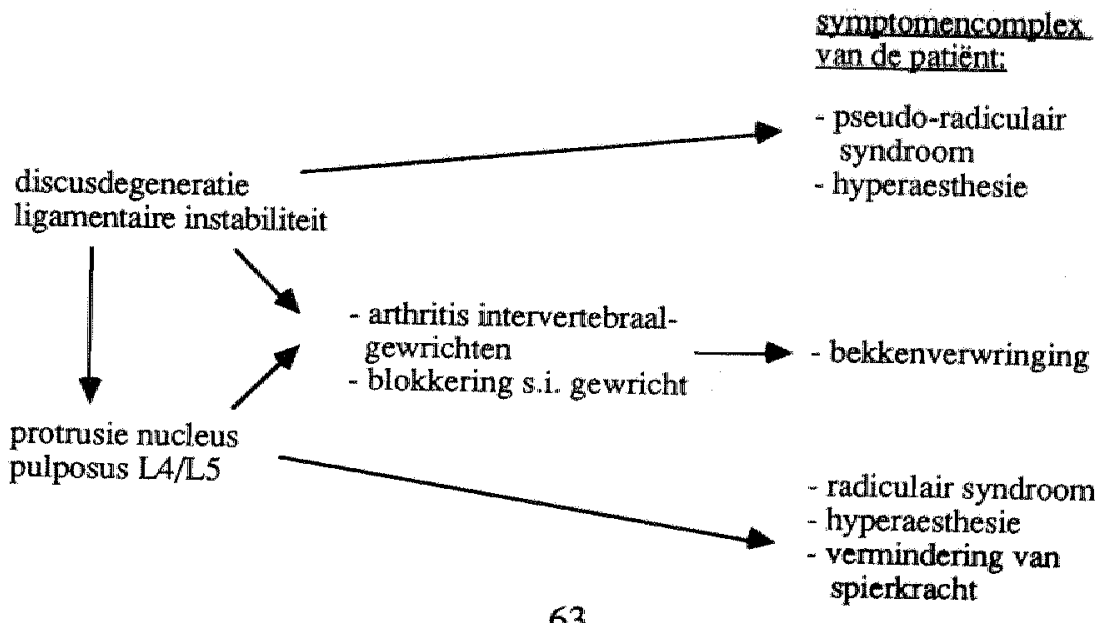


Samenvattend: In deze experimentele studie werd dus het volgende materiaal gebruikt:

1. een casus (diagnose-sleutel: 7 items)

2. twee analogie-teksten met schema's

3. een verzameling van 15 kennis-items

\section{Procedure}

De totale groep deelnemende proefpersonen van 79 personen werd verdeeld in twee groepen: de experimentele groep $(n=33)$ en de controle-groep $(n=46)$. Beide groepen werden tegelijkertijd ongeveer twee weken voorafgaande aan de presentatie van de casus getoetst op de beheersing van de voor de casus relevante kennis. De groepen werden voor de casus-toets verdeeld over twee ruimten. De controle-groep kreeg alleen de casus met de volgende instructie:

In het bijbehorende boekje is een volledige casus uit de fysiotherapeutische praktijk beschreven. De inhoud van de casus is geordend in 5 rubrieken:

1. anamnese

2. inspectie

3. onderzoek en tests

4. metingen

5. palpatie

$U$ moet alle gegevens rustig doorlezen. Daarbij mag $U$ aantekeningen maken als $U$ belangrijke gegevens apart wilt houden. Als $U$ de casus voldoende hebt bestudeerd moet $U$ de volgende opdracht uirvoeren:

Op het antwoordformulier met het kopje DIAGNOSE geeft $U$ de diagnose op orgaanniveau. Dit is een deel van de diagnose dat kan dienen als uitgangspunt voor het opstellen van een behandelplan.

Een voorbeeld: De diagnose 'tenniselleboog type II' is in dit opzicht fout. Beter is om te spreken van een insertie tendopathie musculus extensor carpi radialis brevis.

Bedenk dat een diagnose uit meerdere elementen kan bestaan.

Bijwoorbeeld: $\mathrm{Er}$ is sprake van een ruptuur van lig. collaterale mediale en een laesie van de mediale meniscus met als gevolg een antero-mediale knie-instabiliteit.

De experimentele groep kreeg direct voorafgaande de casus-toets de twee studie-teksten gepresenteerd als toets onder de volgende opdracht: 


\section{Instructîe}

In beide studieteksten wordt het symptomencomplex van een patient gepresenteerd. Deze worden tevens in een schema samengevat. Welke overeenkomst ziet u tussen beide teksten? Schrijf deze op, op het antwoordformuljer.

Deze antwoordformulieren werden ingenomen voor een controle-analyse of de analogie door de proefpersonen in de experimentele groep was gezien. De instructie bij de casus van de experimentele groep werd uitgebreid met de expliciete hint om de resultaten van de tekstvergelijking uit de vorige opdracht te gebruiken in de oplossing van de casus. De proefpersonen werden uiteraard niet gewezen op de inhoudelijke overeenkomsten tussen de kennistoets en de casus.

\section{Analyse}

De doelstelling van het experiment was een relatie aan te tonen tussen de aanwezigheid van kennis en de probleemoplosvaardigheid door middel van een bewuste activatie van die kennis in de probleemcontext. Dit verband. tussen deze twee variabelen zal op gelijke wijze worden geanalyseerd als in Studie 2: door middel van berekening van de kans op succesvol probleemoplossen bij aanwezigheid van kennis. Dit zijn de zogenaamde conditionele kansen die berekend worden in een analyse van kruistabellen van afzonderlijke kennis-items met daaraan gerelateerde items van de diagnose-antwoordsleutel. De conditionele kansen ' $\mathrm{p}\left(\text { goed } / \text { goed }_{\mathrm{k}}\right)^{\prime}$ zijn de kansen op een goede probleemoplossing onder de voorwaarde dat het kennis-item goed werd beantwoord ${ }^{2}$. De controle-groep en experimentele groep zullen met betrekking tot dit verband worden vergeleken. Aangenomen mag worden dat, wanneer de experimentele manipulatie succesvol is, de conditionele kansen in de experimentele groep gemiddeld genomen hoger zijn dan in de controle-groep.

Een steekproef uit de antwoorden van de proefpersonen werd beoordeeld door twee beoordelaars. De mate van overeenkomst tussen beide beoordelaars bedroeg $89 \%$. Op basis van de verschilpunten is de diagnosesleutel licht bijgesteld en werden alle casus opnieuw beoordeeld. $\mathrm{Na}$ deze ronde bedroeg de mate van overeenkomst tussen beide beoordelaars $96 \%$. Voor de resterende gevallen werd een definitieve beoordeling uitgevoerd door beide beoordelaars in gezamenlijk overleg.

${ }^{2}$ Zie voor een uitwoeriger bespreking van deze analyse-methode met voorbeelden de tekst ower Studie 2. 
De verzameling kennis-items werd op de gebruikelijke wijze geanalyseerd. Vooraf waren de items uit de kennistoets toegewezen aan de items van de diagnose-sleutel in de casus-toets. Het antal kennis-items is groter dan het aantall casus-items. Voor de totaal-analyse tussen kennis en probleemoplossen werden eerst de conditionele kans berekend bij de vijftien kennis-items afzonderlijk. Indien een item van de diagnose-antwoordsleutel was gerelateerd aan meerdere kennis-items werd het gemiddelde van deze kansen berekend.

In de volgende paragraaf zullen de resultaten worden gepresenteerd van de vergelijking tussen beide groepen. Binnen de experimentele groep is achteraf beoordeeld of de analogie tussen de beide teksten was begrepen. Dit was mogelijk omdat de proefpersonen de resultaten van de opdracht tot tekstvergelijking ook hadden ingeleverd. Bij een 'goed begrip' van de analogie moesten de ingeleverde notities een ordening van symptomen bevatten die overeenkwam met de schema's bij de studlie-teksten. Deze controle had als resultaat dat 15 proefpersonen buiten de oorspronkelijke experimentele groep werden gehouden omdat uit hun teksten in onvoldoende mate bleek dat zij een juiste analogie hadden gebruikt.

Ook in deze studie werd de kwaliteit van de meetinstrumenten bepaald door middel van toetsing of er significante afwijkingen bestaan met het Rasch-model. Deze analyse werd uitgevoerd met de toets van Anderson (Gustaffson, 1977). Alleen als de toets geen significante afwijkingen vertoont is de item-verzameling kwalificeerbaar als een goed instrument. De resultaten van deze toetsing waren de volgende: Verzameling kennis-items Chi-kwadraat: 34.94 , df $=14, \mathrm{p}=.0015$; Casus Lumbago Chi-kwadraat: $20.32, \mathrm{df}=6, \mathrm{p}=.0024$. Uit deze gegevens blijkt dus dat beide instrumenten 'als geheel' niet aan de vereiste voorwaarden voldoen, immers beide item-verzamelingen wijken significant af. Het overzicht van de item-parameters bij de toetsresultaten geeft precies aan in welke mate de afzonderijke items significant afwijken (paarsgewijze t-test van lage- en hoge-scoregroepen). Van verwijdering van items en hertoetsing van de resterende item-verzameling is afgezien omdat de hypothese getoetst wordt op itemniveau en niet op het niveau van de schaal van het instrument. De basis voor de hypothese-toetsing is de berekening van de kans op een goede probleemoplossing indien de gerelateerde kennis-items goed zijn beantwoord. Indien meer dan én kennisitem was verbonden met het diagnose-item werd daarbij de gemiddelde kans berekend. Vier items van de kennistoets vertoonden sterk significante afwijkingen $(t>2.0)$ met de eigenschappen van het Rasch-model en zijn bij deze toetsing buiten beschouwing gebleven. Aan de kant van de casus voldeed één item niet aan de gestelde voorwaarden. Samenvattend: bij een oorspronkelijke schaal van zeven items van de casus werd zes maal berekend welke kans er bestond op een goed ant- 
woord indien de gerelateerde kennis-items goed waren beantwoord. Voor deze kans-berekening werden alleen de kennis-items gebruikt die voldeden aan de eisen van het Rasch-model.

\section{Resultaten}

Op de kennistoets die twee weken voorafgaande aan de casus werd afgenomen scoorden beide groepen als weergegeven in Tabel 6.

Tabel 6: Resultaten kennistoets voor controlegroep en experimentele groep

\begin{tabular}{lcccc}
\hline & Gemiddelde & S.D. & Range & N \\
\cline { 2 - 5 } Controle-groep & 7.67 & 2.29 & $2-13$ & 46 \\
Experimentele groep & 7.27 & 1.96 & $3-12$ & 33 \\
\hline
\end{tabular}

Een $t$-test op de gegevens in Tabel 6 geeft het volgende resultaat: $t=.80$ (n.s.) waaruit kan worden geconcludeerd dat beide groepen een vergelijkbaar kennisniveau hadden.

In Tabel 7 staan de resultaten van de verschillende groepen van de casus. De eerste kolom van deze tabel bevat de verschillende onderdelen van de diagnose-antwoordsleutel die hier als afzonderlijke items geanalyseerd worden, de overige kolommen bevatten de percentages goede antwoorden op deze diagnose-elementen.

Tabel 7: Percentages goede antwoorden op casus-items voor alle groepen

\begin{tabular}{ccc} 
Controle & Experimentele & Experimentele \\
groep & groep (totali) & groep/analogie \\
$n=46$ & $n=33$ & $n=18$ \\
\hline
\end{tabular}

arthritis intervertebraal gewrichten blokkering s.i.-gewricht

21

ligamentaire instabilliteit

nucleus pulposus $\mathrm{L} 4 / \mathrm{L} 5$

protrusie

pseudo-radiculair syndroom

radiculair syndroom
83

17

50

31

41.

57
27

60

7

70

37

57

57
17

67

11

77

39

61

56 
In de inleiding tot deze studie werd de veronderstelling geuit dat de proefpersonen die beschikken over de benodigde kennis én waarvan de kennis is geactiveerd door de analogie-manipulatie een hogere kans op een goede probleemoplossing hebben dan de proefpersonen waarvan de kennis niet is geactiveerd. De analyse was gericht op een wergelijking van de kansen op een goede oplossing tussen de verschillende groepen. De experimentele groep waarover de zekerheid bestond dat een juiste analogie werd gebruikt als kennis-activatie is in deze vergelijking met name van belang. De resultaten van deze analyse staan weergegeven in Tabel 8 . De analyses die de basis vormen voor de in Tabel 8 weergegeven resultaten werden uitgevoerd voor elk kennis-item afzonderlijk. Indien meer dan één kennis-item met het probleemoplos-item was verbonden werd de gemiddelde kans berekend en voor de phi-coëfficiënten werd het gemiddelde berekend.

Tabel 8: Kansen op een goed antwoord op casus-item bij aanwezigheid kennis en het verband tussen kennis en probleemoplossen voor alle groepen

\begin{tabular}{|c|c|c|c|c|c|c|c|c|c|}
\hline & \multicolumn{3}{|c|}{$\begin{array}{c}\text { Controle } \\
\text { groep } \\
n=46\end{array}$} & \multicolumn{3}{|c|}{$\begin{array}{c}\text { Experimentele } \\
\text { groep (totaal) } \\
n=33\end{array}$} & \multicolumn{3}{|c|}{$\begin{array}{l}\text { Experimentele } \\
\text { groep/analogie } \\
\mathbf{n}=18\end{array}$} \\
\hline & Kans & phi & $\begin{array}{l}\text { phi } \\
\max .\end{array}$ & Kans & phii & $\begin{array}{l}\text { phi } \\
\text { max. }\end{array}$ & Kans & phi & $\begin{array}{l}\text { phi } \\
\max \end{array}$ \\
\hline $\begin{array}{l}\text { arthritis interverbraal } \\
\text { gewrichten }\end{array}$ & .08 & .40 & .43 & .24 & .08 & .52 & .18 & .05 & .36 \\
\hline blokkering s.i.-gewricht & 1.00 & .12 & .28 & 3 & .15 & .23 & & & \\
\hline ligamentaire instabiliteit & .24 & .15 & .54 & & .19 & .38 & & .22 & .57 \\
\hline nucleus pulposus L4/L5 & .52 & .22 & .67 & .78 & .15 & .75 & .83 & .12 & .67 \\
\hline protrusie & .23 & .11 & 1.00 & .41 & .11 & .67 & .36 & .06 & .64 \\
\hline pseudo-radiculair syndroom & n. .44 & .12 & .54 & .59 & .09 & .71 & .60 & $\llbracket 1$ & .79 \\
\hline radiculair syndroom & .56 & .17 & .82 & .57 & .25 & .87 & .60 & .32 & .89 \\
\hline
\end{tabular}

Inspectie van de resultaten in Tabel 8 leidt tot de conclusie dat het gewenste experimentele effect, een verhoogde kans op een goede probleemoplossing als de kennis-items van de voorafgaande toets goed beantwoord zijn, in een beperkt aantal gevallen aanwezig is. Echter, het effect is gering. De

${ }^{*}$ Indien geen der kennis-items goed werd beantwoord kon in deze analyse geen kans op een goede oplossing berekend worden. 
gemiddelde kans op een goede oplossing ${ }^{4}$ bedroeg voor de controle-groep .37 en voor de experimentele groep, met uitsluiting van de proefpersonen waarover onzekerheid bestond of de juiste analogie was gebruikt, $44(t=$ 1.0 , $\mathrm{df}=5, \mathrm{n} . \mathrm{s}$.). Ook de sterkte van de verbanden tussen de kennis-scores en de probleemoplos-scores nam niet toe als gevolg van de experimentele manipulatie. De gemiddelde waarde van de phi-coefficiënten van de controle-groep bedroeg .17 (phi maximaal: .54) en voor de experimentele groep .12 (phi maximaal: .67). Samenvattend leiden deze resultaten tot de conclusie dat de experimentele manipulatie in de vorm van een analogie niet heeft geleid tot de gewenste activatie van kennis.

\section{Discussie}

In deze studie is getracht aan te tonen dat het succesvol probleemoplossen niet uitsluitend wordt bepaald door de aanwezigheid van probleemrelevante kennis maar mede wordt beïnvloed door activatie van de beschikbare kennis. Op basis van de resultaten van de eerste twee studies, waarin metingen werden verricht met parallel geconstrueerde en inhoudelijk verwante instrumenten, werd geconcludeerd dat er een zwak verband tussen kennisbeheersing en probleemoplosvaardigheid bestaat. We veronderstelden dat niet alleen de aanwezigheid van de kennis bepalend is, maar ook de mate waarin de kennis wordt geactiveerd tijdens het probleemoplossen. In onderzoek naar het denkproces tijdens het diagnostiseren van artsen onderscheidden Gale en Marsden (1983) twee onderling gerelateerde psychologische activiteiten: structurering en extrapolatie. Onder extrapolatie wordt verstaan dat het denkproces wordt verrijkt met concepten die zijn ontleend aan de door de probleem-analyse geactiveerde aanwezige kennis. Deze extrapolatie wordt gefaciliteerd door een goede structurering van de probleeminformatie tijdens de analyse van het probleem. Een onvolledige, of niet adequate, structurering van de probleem-informatie werd aangewezen als verklaring voor het niet-actief worden van de relevante kennis en daarmee voor de geringe sterkte van het verband tussen kennisbeheersing en probleemoplossen. In het experiment werd door middel van een analogie een hint gegeven de probleeminformatie zodanig te structureren dat de aanwezige kennis wél geactiveerd zou worden. Daarbij moest de analogie aan twee voorwaarden voldoen: transparantie en systematiek (Gentner \& Toupin, 1986).

${ }^{4}$ Met uitsluiting van de kans op item 2 omdat die voor de experimentele groep niet berekend kon worden. 
De inhouds-analyse van de teksten die de proefpersonen produceerden naar aanleiding van de opdracht de overeenkomsten tussen beide studieteksten op te schrijven geeft aanleiding tot twee overwegingen: 1 . De proefpersonen hadden moeite met het ontdekken van de analogie in de twee casus-teksten. Deze conclusie is gebaseerd op het feit dat $40 \%$ van de proefpersonen die waren ingedeeld bij de experimentele groep buiten de analyse moesten blijven van het experimenteel effect. Na kennisneming van hun aantekeningen, die het resultaat waren van de opdracht tot tekstvergelijking bestond onvoldoende zekerheid dat de analogie, de door de schema's voorgestelde structuur van de probleeminformatie, werd begrepen. Desalniettemin was er ook geen sprake van beter probleemoplossen indien uit de teksten van de proefpersonen bleek dat de analogie wél begrepen was. Dit geeft aanleiding tot de tweede overweging: 2 . De in de analogie gesuggereerde structurering van de probleeminformatie leidt niet tot activatie van de relevante kennis. Beide overwegingen zullen worden bediscussieerd vanuit twee gezichtspunten: 1. de hier gebruikte experimentele methode, en 2 . de aard van de benodigde kennis voor de oplossing van het probleem in de casus-toets.

De proefpersonen in deze studie, die voor de meerderheid dezelfde proefpersonen waren als in beide voorgaande studies, waren gewend getoetst te worden op hun kennis en vaardigheid in diagnostiek. Alle toetsen, kennis- en casus-toetsen, werden afzonderlijk gepresenteerd. Als toelichting op de achtergrond van de studies werd de proefpersonen medegedeeld dat bij een zelfde groep proefpersonen ervaring werd opgedaan met verschillende toetsvormen. Zorgvuldig werd vermeden om impliciet informatie te verschaffen over de inhoudelijke verwantschap tussen de verschillende toetsen. Ook de tekst-vergelijkingsopdracht, alleen gepresenteerd aan de experimentele groep, werd gepresenteerd als een op zich zelf staande toets. De aanwijzing dat de resultaten van deze tekstvergelijking gebruikt konden worden in de daaropvolgende casus-toets werd schriftelijk gegeven in de casus-toets. De mogelijkheid bestaat dan ook dat het effect van deze aanwijzing te klein is geweest voor een gerichte activatie van de kennis zoals was bedoeld. Spencer en Weisberg (1986) onderzochten de context-afhankelijke effecten van analogie-transfer in een replicatie-onderzoek met exact dezelfde instrumenten als Gick \& Holyoak. Ook Spencer \& Weisberg presenteerden hun proefpersonen enkele studieteksten over convergentie-problemen (het veroveren van een fort langs verschillende wegen, het blussen van een grote brand vanuit verschillende standpunten) om vervolgens het (convergentie-) stralingsprobleem voor te leggen (het vernietigen van een tumor door middel van bestraling met lage doseringen uit verschillende richtingen). Het verschil tussen de designs van Spencer \& Weisberg enerzijds en 
Gick \& Holyoak anderzijds betrof de wijze van presentatie van hun instrumenten. Spencer en Weisberg introduceerden het stralingsprobleem als een inleiding op een volgend college, de analogie-teksten en opdrachten werden door een andere proefleider vooraf gepresenteerd als een pilot-experiment. In de tijd tussen de tekstvergelijking en de presentatie van het probleem verrichtten de proefpersonen gedurende enkele minuten andere taken. Deze wijzigingen in de experimentele context hadden sterke effecten op de resultaten van de proefpersonen in vergelijking met de door Gick \& Holyoak gerapporteerde resultaten. Rapporteerden laatstgenoemden dat $45 \%$ van hun proefpersonen zonder hulp het probleem oplosten, Spencer \& Weisberg rapporteerden slechts $5 \%$. Laatstgenoemden constateerden dat de kwaliteit van de analogie-beschrijving van de proefpersonen geen hoofdeffect was zoals Gick \& Holyoak concludeerden: bij een goede analogie-beschrijving door de proefpersonen werd het doelprobleem beter opgelost indien de instrumenten op gelijke wijze werden gepresenteerd. Echter werd de wijze van presentatie van de instrumenten gewijzigd dan werd ook bij een goede analogie-beschrijving geen toename van het aantal goede probleemoplossingen gevonden. Ook in de in dit hoofdstuk gerapporteerde studie werd uitgegaan van een hoofdeffect van de analogie. De opzet van deze studie verschilde echter sterk ten aanzien van de wijze van presentatie door Gick en Holyoak. Immers, de analogie-opdracht en de casus werden als afzonderlijke toetsen gepresenteerd. Op basis van de waarnemingen van Spencer en Weisberg moet derhalve rekening worden gehouden met een context-effect dat sterker is dan het effect van de analogie zoals die is waargenomen door de proefpersonen.

Naast het verschil in de wijze van presentatie van de instrumenten is er in vergelijking van deze studie met de experimenten van Gick en Holyoak ook sprake van een verschil in de aard van de kennis die gebruikt moet worden in de oplossing van de doel-problemen. Dit verschil kan ook de oorzaak zijn van het achterwege blijven van een experimenteel effect. De analogie die werd aangereikt in de beide studie-teksten in het door ons gerapporteerde experiment had betrekking op een algemeen principe: een acute verandering in een chronisch klachtenbeeld van een patiënt. Dit principe is algemeen omdat het van toepassing kan zijn op de fysiotherapeutische diagnostiek van klachten of aandoeningen in verschillende lichaamsregio's. Daartoe moet in de diagnostiek voor de behandeling een onderscheid worden gemaakt tussen een degeneratief symptomencomplex en de acute symptomen. Beide symptomencomplexen zijn echter niet onafhankelijk. De degeneratieve symptomen veroorzaken een overbelasting van bepaalde gewrichten en veroorzaken dientengevolge de acute symptomen. Kennis van dit principe is echter niet voldoende om de diagnose te formuleren, het princi- 
pe zal moeten worden uitgewerkt in een concrete formulering waarbij specifieke anatomische en pathologische concepten gebruikt worden. Deze concepten ên đè relaties hiertussen waren verwerkt in de items van de kennistoets en moesten worden toegepast in het diagnostiseren. In de experimenten van Gick en Holyoak had de analogie ook betrekking op een algemeen principe (convergentie) maar was het voor de oplossing van het doelprobleem niet noodzakelijk dit principe toe te passen op specifieke kennis. Anders geformuleerd: in de experimenten van Gick en Holyoak werd het doelprobleem opgelost door het algemene (convergentie-)principe te vertalen in binnen het probleem gehanteerde concepten (straling, dosering, richting, etc.). Daarentegen moest in het in dit hoofdstuk beschreven experiment een algemeen principe de benodigde specifieke kennis activeren. In de bespreking van de door anderen verrichte analogie-experimenten werd reeds aangegeven dat er een relatie werd verondersteld tussen de vaardigheid in analogisch denken en expertise in probleemoplossen. Daarbij werd er vanuit gegaan dat domeinspecifieke heuristieken voortbouwen op domeinonafhankelijke heuristieken. Dit verband is niet omkeerbaar: het was opvallend te constateren dat de diagnose-formuleringen van de proefpersonen in de experimentele groep vaak de goede ordening van symptomen bevatte die echter niet resulteerde in een concrete afronding. Kortom, het principe werd gezien en overgenomen maar daarmee werd in een aantal gevallen volstaan. De ordening van de symptomen op zich activeerde niet de benodigde kennis die nodig was voor de juiste interpretatie van deze symptomen. In de inleiding op dit experiment werden drie denkprocessen onderscheiden: prediagnostische interpretatie (globale probleemdefiniëring die echter niet specifiek genoeg is voor een waarschijnlijkheidsdiagnose); diagnostische interpretatie (meer specifiek met aandacht voor de pathofysiologische processen); behoefte aan nadere informatie (onafhankelijk van waarschijnlijkheidsdiagnose). De aangereikte analogie om de symptomen te ordenen in acute en chronische symptomen betekent in feite dat hulp wordt geboden bij de pre-diagnostische interpretatie (structurering) ten einde de diagnostische interpretatie te vergemakkelijken. Het achterwege blijven van de activatie van beschikbare kennis door de analogie moet dus worden geinterpreteerd als het achterwege blijven van de juiste diagnostische interpretatie. De waarschijnlijkheidsdiagnose is gericht op een specifieke aandoening van de patiënt. Anatomische en pathologische kennis die is verwerkt tot samenhangende 'kennis over aandoeningen' zal derhalve geactiveerd worden bij de waarschijnlijkheidsdiagnose over een aandoening. Deze zienswijze op de activatie van kennis staat haaks op de zienswijze die is geoperationaliseerd in de opzet van het experiment. Immers, in het experiment werd getracht de proefpersonen tot een juiste waarschijnlijkheidsdiagnose te brengen op 
basis van een activatie van beschikbare kennis. Daarbij wordt er impliciet vanuit gegaan dat men redeneert op basis van losstaande feiten naar een oplossing toe. De feitelijke gang van zaken in het denkproces zal waarschijnlijk de omgekeerde zijn: de probleem-informatie leidt tot een 'herkenning' van een mogelijke diagnose. Deze voorlopige diagnose functioneert als een hypothese die wordt geverifieerd in het denkproces. Daarbij wordt de onderliggende kennis geactiveerd en toegepast. Het achterwege blijven van de activatie van kennis door de analogie kan derhalve geinterpreteerd worden vanuit het ontbreken van voldoende samenhang in de kennis over aandoeningen bij de proefpersonen. Een bevestiging van deze opvatting vinden we bij Hayes (1982) die, ook in een analogie-experiment, ontdekte dat een analogie wel algemeen gerelateerde kennis activeert maar in mindere mate specifieke kennis. Een groep proefpersonen leerde de regels wan het cricket-spel op basis van teksten waarin analogieën waren opgenomen met het honkbal-spel. In een regressie-analyse werd aangetoond dat de voorkennis over honkbal meer variantie verklaarde dan elke andere factor.

Topp, Kulhavy en Webb (1986) constateerden dat 'encoding schemata' (de organisatie van kennis in de fase van verwerving) een sterkere invloed hebben op herinnering of herkenning dan 'retrieval schemata' die worden gevraagd te gebruiken in herinneringstaken. Deze constatering is gebaseerd op de 'encoding specificity'-theorie (Tulving en Thomson, 1973) waarin benadrukt wordt dat de structuur waarbinnen de verworven kennis is geplaatst tijdens het leerproces intermediëert bij de herinnering van de kennis op een later tijdstip. In een praktijkprobleem zal niet op de eerste plaats de structuur van één leerstofdomein een rol spelen maar de structuur die aansluit bij de taak: diagnostiek van aandoeningen. De samenhang tussen kennis en probleemoplossen zal derhalve benaderd moeten worden vanuit de ontwikkeling van vakgebonden kennis naar geïntegreerde kennis over aandoeningen. In de studie in het volgende hoofdstuk zal worden onderzocht of het formuleren van een goede diagnose samenhangt met verschillen in de kwalitatieve kenmerken van kennis over diagnostiseerbare aandoeningen. 


\section{HOOFDSTUK 5}

\section{Kwalitatieve kenmerken van kennis en hun relatie met het oplossen van problemen}

\section{Inleiding}

In het experiment uit het vorige hoofdstuk werd getracht de aanwezige kennis te activeren door het geven van een hint aan de probleemoplosser. Afgezien van het feit dat het experiment niet de beoogde resultaten had roept de opzet van het experiment, het activeren van kennis door middel van hulp, uiteraard ook een aantal vragen op voor de alledaagse praktijk van probleemoplossen. Een fysiotherapeut zal bij het onderzoek van zijn patiënt zelfstandig zijn aanwezige kennis moeten activeren. Anders gezegd, indien de activatie van kennis bepalend is voor de kwaliteit van de diagnose, en deze kennis zelfstandig zal moeten worden geactiveerd, moet activatie van kennis afhankelijk zijn van eigenschappen van deze kennis zelf. In de eerste drie studies naar het verband tussen kennis en probleemoplossen werd van de kennis alleen de aanwezigheid gemeten. In deze vierde studie zal opnieuw de aanwezigheid van relevante voorkennis worden gemeten, echter de kennis van de probleemoplossers zal aanvullend worden onderworpen aan een gedetailleerde kwalitatieve analyse. De resultaten van deze analyse zullen in verband worden gebracht met de juistheid van de probleemoplossing.

Het inzicht dat eenmaal verworven kennis onder invloed van ervaring verandert wordt ontleend aan theorieën over cognitieve ontwikkeling. Deze theorieën liggen ten grondslag aan onderzoek binnen het zogenaamde expert-noviet paradigma, waarin de probleemoplosvaardigheid van groepen proefpersonen, die verschillen in ervaring, met elkaar worden wergeleken. Vergelijkingen van ervaren en beginnende probleemoplossers tonen aan dat beide groepen gedurende het proces van probleemoplossen informatie op andere wijze verwerken: novieten en experts representeren problemen ver- 
schillend. Een representatie van een probleem wordt veronderstell het resultaat te zijn van de interactie tussen objectieve probleeminformatie en de door het probleem geactiveerde kennis. Nadere analyses van de samenhang tussen probleemrepresentatie en kennis hebben tot het inzicht geleid dat ervaren probleemoplossers beschikken over een kennisbestand dat van een andere aard is, en meer in overeenstemming is georganiseerd met de situatie waarin de kennis gebruikt moet worden. In de eerstvolgende paragraaf zullen verschillen tussen experts en novieten uitvoerig worden besproken. De studies die besproken zullen worden zijn gekozen en gerangschikt als introductie op de centrale vraagstelling van de in dit hoofdstuk te bespreken studie. In de bespreking zal aandacht worden geschonken aan de aard van de probleemrepresentatie, de waarneming van de probleeminformatie, de interactie tussen waarneming en kennis, de organisatie van de kennis en het verband tussen de organisatie van kennis en de aard van de gebruikte kennis. Deze bespreking wordt afgesloten met een evaluatie van de betekenis van het besproken expert-noviet onderzoek voor de hier te rapporteren studie. In onderzoek naar verschillen tussen experts en novieten worden veelal groepen geselecteerd die sterk van elkaar verschillen in mate van expertise in het betreffende domein. Dat gebeurt om de kans op betekenisvolle verschillen in kennis, kennisorganisatie en kennisgebruik te maximaliseren. In de in dit hoofdstuk te bespreken studie zijn echter verschillen gezocht binnen een betrekkelijk homogene groep, namelijk derdejaars fysiotherapie-studenten. Experts lossen problemen beter op én beschikken over kennis die kwalitatief verschilt van novieten. Is een dergelijke samenhang echter ook te vinden in een betrekkelijk homogene groep? Beschikken studenten die problemen beter oplossen ook over een uitgebreider, anders georganiseerd en kwalitatief verschillend kennisbestand? Deze vragen vormen de basis voor hypothesen waarin verbanden worden getoetst tussen de juistheid van probleemoplossingen en probleemrepresentatie en tussen de juistheid van probleemoplossingen en de kwaliteit van de aanwezige kennis.

\section{De ontwikkeling van kennis: van noviet tot expert}

\section{Expertise}

Het psychologisch onderzoek naar de vaardigheid in probleemoplossen is in de afgelopen 20 jaar in een stroomversnelling gekomen. Voordien hield een beperkt aantal onderzoekers zich weliswaar bezig met onderzoek naar 'het denken', maar de overheersende behavioristische wetenschapsopvatting belette dat er sprake kon zijn van de ontwikkeling van een alternatief paradig- 
ma. Onder invloed van een naïef natuurwetenschappelijk ideaalbeeld was de mening gangbaar dat slechts objectief en uiterlijk waameembaar gedrag van een subject onderwerp kan zijn van wetenschappelijk onderzoek. Het is dan ook opvallend dat vrijwel elke literatuurlijst van recent cognitief psychologisch onderzoek naar het verband tussen kennis en probleemoplossen slechts een enkele verwijzing bevat naar literatuur meer dan 15 jaar geleden gepubliceerd. Een uitzondering hierop zijn de verwijzingen naar het werk van De Groot (1946). In dit onderzoek naar het denken van schakers introduceert De Groot een psychologische beschrijving van het begrip 'meesterschap'.

"Ik heb hier getracht aan te tonen, dat wij in de meeste gevallen (niet alleen in het schaakspel), waarin gesproken kan worden van intuitieve voorkeur, te doen hebben met werkzaamheid van ervaring-in-engere-zin. ... Begaafd is hij die de capaciteiten bezit, nodig voor de opbouw van dat uitgebreide, ver gedifferentieerde, geordende en verfijnde systeem van adequate denkgewoonten en -methoden, dat wij met de term 'meesterschap' karakteriseren. Deze begripsbepaling, die geheel in de geest van de denkpsychologie is, maar bij mijn weten nog niet eerder in deze of analoge vorm werd uitgesproken, verlegt het accent van de vaak zo misleidende 'aangeboren talenten' en 'gaven' naar het ontwikkelingspsychologische aspect en naar de eigenlijke prestatie (nl. de opbouw van het ervaringssysteem), die door het subject moet worden geleverd." (De Groot, 1946, p. 300)

Dit citaat bevat voor een belangrijk gedeelte de elementen die ook aanwezig zijn in recente publicaties van onderzoek naar verschillen tussen novieten en experts: kennis (een uitgebreid, gedifferentieerd en geordend systeem), ervaring ('de opbouw van het ervaringssysteem') en ontwikkeling. Eveneens opvallend is dat de Groot reeds 40 jaar geleden poneerde dat zijn theoretische inzichten zich niet beperken tot het schaakspel maar dat er sprake is van een psychologisch concept 'meesterschap' dat van toepassing is op allerlei gebieden.

De Groot liet onder andere schakers van verschillend niveau van expertise stellingen, die slechts gedurende ongeveer 5 seconden waren getoond,

"Tegenwoordig spreekt men, mede onder invloed van veelal Amerikaans onderzoek op dit terrein, liever van 'expertise'. 
op het bord reproduceren. Ondat de bestuderingstijd kort was, was het dus onmogelijk de posities van de afzonderlijke stukken te memoriseren. De hoevelheid aangeboden informatie was daarvoor te omvattend en te complex. Experts voerden deze taak beter uit dan schakers van lager niveau. Dit resultaat doet vermoeden dat een expert de aangeboden informatie anders verwerkt. Te meer daar Chase en Simon (1973) aantoonden dat dit verschil in prestatie alleen tot stand kwam als de gepresenteerde schaakstellingen betekenisvol waren. De gepresenteerde schaakstellingen waren namelijk afkomstig uit partijen uit de schaakliteratuur, of waren daar een variant van. $\mathrm{Bij}$ een willekeurige positionering van stukken op het bord werden geen verschillen in geheugenprestatie tussen schakers van verschillend niveau gevonden. Dit gegeven is illustrerend voor de wijze waarop aanwezige voorkennis van invloed is op de waarneming van nieuwe informatie.

De interactie tussen waarneming en kennis en de vorming van een probleemrepresentatie

Onderzoek naar de wijze waarop aangeboden informatie gedurende het proces van probleemoplossen wordt verwerkt, is meestal gericht op de probleemrepresentatie van de probleemoplosser. Immers, in de representatie van het probleem in kwestie wordt weerspiegeld welke aspecten van het geheel aan informatie-aanbod actief verwerkt worden. Onderzoekers in verschillende domeinen hebben aangetoond dat er een samenhang bestaat tussen de kwaliteit van de probleemrepresentatie en de mate van expertise in het betreffende domein.

Op het terrein van het natuurkundig probleemoplossen analyseerden Chi, Feltovich en Glaser (1981) en Chi, Glaser en Rees (1982) hardop-denkprotocollen van novieten en experts. $\mathrm{Zij}$ concludeerden dat de probleemrepresentatie het resultaat is van een categorisatie in de beginfase en een invulling van deze initiële representatie op basis van beschikbare kennis. Twee processen van informatie-verwerking worden onderscheiden: 1. 'Bottom-up': de probleeminformatie (cues) wordt geanalyseerd en leidt tot probleemherkenning (globale probleemcategorisatie), 2. 'Top-down': de probleeminformatie wordt aangevuld met de kennis die is geactiveerd door de probleemherkenning. Experts en novieten verschillen kwalitatief in de verwerking van de waargenomen informatie: experts categoriseren problemen in probleemtypen op basis van concepten die het resultaat zijn van het toekennen van betekenis aan deze problemen in termen van onderliggende principes of wetten. Chi en haar collega's spreken in dit verband van 'stilzwijgende kennis' die gebruikt wordt in de probleem-analyse op basis van een diepte-structuur (experts) in tegenstelling tot een categorisatie op basis van een oppervlakte-structuur (novieten). Een belangrijke functie van de 
initiele probleemcategorisatie is selectie: de categorisatie beperkt het aantal mogelijke oplossingshandelingen die vervölgens analytisch onderzocht kunnen worden. Echter, belangrijk in dit verband is dat de selectie van informatie wordt verondersteld samen te hangen met de kennis van de probleemoplosser. Dit gegeven, de interactie tussen waarneming en kennis, komt ook naar voren in de volgende onderzoeken.

Ook Larkin (1983) onderzocht de rol van de piobleemrepresentatic in natuurkundig probleemoplossen. Larkin maakt een onderscheid tussen een naieve representatie, die bij novieten aangetroffen wordt, en een natuurkundige representatie die experts reproduceren. $\mathrm{Bij}$ het onderscheid tussen beide representatie-vormen benadrukt Larkin het gegeven dat niet de omvang van de kennis die een persoon heeft bepalend is voor de kwaliteit van de representatie van een probleem maar de mate waarin deze kennis goed is georganiseerd. Goed georganiseerde kennis stelt de expert in de gelegenheid om na herkenning van de probleeminformatie relevante kennis in zeer korte tijd te activeren. De snelheid en nauwkeurigheid waarmee experts de voorgelegde problemen oplossen is het resultaat van het vermogen om meer informatie tegelijkertijd te kunnen verwerken. Dit proces wordt 'chunking" genoemd. Het korte-termijn geheugen wordt daarbij minder belast en derhalve wordt de kans op het maken van fouten kleiner.

Chunking staat centraal in het onderzoek van McKeithen, Reitman, Reuter en Hirtle (1981) waarin beginnende en gevorderde computerprogrammeurs de opdracht kregen een computer-programma (geschreven in ALGOL) korte tijd te bestuderen om deze vervolgens te reproduceren. Deze taak, die opvallende overeenkomsten vertoont met het onderzoek naar schaak-expertise van de Groot, bracht aan het licht dat experts hun taak uitvoerden door informatie uit de programma-listing te combineren. Experts weten bijvoorbeeld dat bij de opdracht 'BEGIN' de opdracht 'END' hoort, dat 'WHILE DO' onder bepaalde voorwaarden een 'loop' initialiseert, etc. De beschikbaarheid van deze kennis leidde ertoe dat de experts tijdens de bestudering van het materiaal voorafgaande aan de reproductie, de structuur van het programma analyseerden en de resultaten van deze structuuranalyse gebruikten bij de feitelijke reproductie. Deze wijze van reproduceren verloopt sneller en roept minder fouten op dan het memoriseren van afzonderlijke programma-regels.

Dijkstra, v.d. Stelt en v.d. Sijde (1983) verrichtten onderzoek onder ervaren en beginnende tandartsen en concludeerden dat experts de probleeminformatie ook letterlijk anders waarnemen, of 'zien', dan novieten. Zij presenteerden hun proefpersonen een aantal röntgenfoto's van gebitten voor nadere diagnostiek. Gedurende de inspectie van de visuele probleeminformatie werden de oogbewegingen en pupilgrootte geregistreerd. In de analyse 
van het waarnemingsgedrag brachten de onderzoekers een onderscheid aan tussen 'visueel opvallende gebieden' en "cognitief opvallende gebieden'. De eerste betroffen de zwart-wit patronen die ook voor een leek opvallend zijn, zoals contouren van de gebitselementen en eventuele restauraties. De gebieden die van belang zijn voor het stellen van een diagnose werden door de onderzoekers als cognitief opvallende gebieden gekarakteriseerd. Dijkstra et al. (1983) stelden vast dat er sprake was van een verschil in het kijkgedrag tussen novieten en experts gedurende de eerste seconde: novieten richten hun aandacht op visueel opvallende gebieden en experts op cognitief opvallende gebieden.

Patel en Coughlin (1986) onderzochten de interactie tussen waameming en beschikbare kennis in het medisch domein. De proefpersonen, ervaren artsen en medische studenten, werd gevraagd een beknopte beschrijving van een patiënt korte tijd te bestuderen en deze vervolgens te reproduceren. De aangeboden teksten waren vooraf verdeeld in proposities, die vergeleken werden met proposities die in de recall-protocols van de proefpersonen teruggevonden werden. Overeenkomstig met de bevindingen van de Groot in de reconstructie van schaakstellingen, en met de bevindingen van McKeithen et al. in het herinneren van computerprogramma's, constateerden Patel et al. dat ervaren artsen de aangeboden medische teksten beter reproduceerden dan beginners. De recall-teksten van novieten (Patel \& Frederiksen, 1984) bevatten meer exact gelijke proposities dan die van experts. Laatstgenoemden voegden informatie toe in de recall. Deze toevoegingen werden gekarakteriseerd als inferenties die het product zijn van de verbinding van de in de originele tekst waargenomen conceptuele structuren met geactiveerde conceptuele structuren in het geheugen. Coughlin en Patel (1986) benadrukken in dit verband het grotere vermogen tot selectieve waarneming van ervaren artsen, gecontrasteerd met novieten die relevante en irrelevante informatie identiek verwerkten.

Probleemoplossen en leren zijn in termen van informatieverwerking op dezelfde cognitieve processen gebaseerd: in beide gevallen worden dezelfde aanwezige kennisstructuren ingezet om informatie te begrijpen die wordt aangeboden, of in de omgeving beschikbaar is. Chiesi, Spilich en Voss (1979) analyseerden de rol van voorkennis in het verwerven van nieuwe informatie in een leerexperiment. Op basis van een kennismeting voorafgaande aan het experiment werden de proefpersonen verdeeld in twee groepen met meer en minder kennis ten aanzien van het desbetreffende domein. Het kennisgebied in kwestie betrof de kennis over de tactiek van het honkbalspel. In het experiment moesten de proefpersonen luisteren naar op band ingesproken spelbeschrijvingen en deze herkennen als 'oud' of 'nieuw' ten opzichte van eerder gepresenteerde spelbeschrijvingen. Chiesi et al. regis- 
treerden het aantal zimnen die de proefpersonen nodig hadden om een correcte beslissing te nemen. De proefpersonen met een hoge score op de voorkennismeting konden met minder informatie deze herkenningstak correct uitwoeren. Chiesi et al. verklaarden deze betere prestatie uit structurele verschillen in kennis ten aanzien van de 'goal structure' van het spel: het doel (winnen) en de middelen waarmee dat doel bereikt kan worden. Afhankelijk van de spelsituatie (slagbeurt voor een team of veldbeurt) zullen verschillende tactische beslissingen moeten worden genomen om de afgeleide doelen te bereiken (bijvoorbeeld het scoren of voorkomen dat de tegenstander scoort). Belangrijk in dit verband is dat Chiesi et al. veronderstellen dat een hiërarchische ordening in kennisniveaus ten grondslag ligt aan de waargenomen individuele verschillen.

Het gemeenschappelijk element in de hierboven besproken onderzoeksresultaten is het volgende. Alle besproken onderzoeken accentueren dat een verschil in probleemoplosvaardigheid verklaard kan worden uit een onderliggend verschil in domeinkennis. De rol die de kennis speelt in het proces van probleemoplossen komt tot uitdrukking in de waarneming en verwerking van probleeminformatie tot een probleemrepresentatie. Processen die van belang zijn in deze waarneming zijn: probleemherkenning, categorisatie, selectie van informatie en het samenvoegen van informatie-eenheden tot 'chunks'. Als conclusie uit de voorgaande studies in dit proefschrift werd gesteld dat aanwezigheid van relevante kennis op zichzelf geen voldoende voorwaarde is voor het succesvol oplossen van een probleem. Uit de onderzoeken die hier besproken werden, komt een aanvullende voorwaarde naar voren die blijkbaar aan bruikbare kennis gesteld moet worden: de structuur van die kennis. Ook dit aspect van kennis zal worden ingeleid door middel van een bespreking van diverse onderzoeken. De bespreking van onderzoek naar verschillen tussen experts en novieten blijft nu beperkt tot het medisch domein, vanwege de verwantschap tussen het medisch domein en het domein van deze studie, het fysiotherapeutische.

De ontwikkeling van vakgebonden kennis tot domeinspectfieke geintegreerde kennis

Structurele niveaudifferentiatie in kennis is het onderwerp van een studie van Feltovich, Johnson, Moller en Swanson (1984) naar de ontwikkeling van medische kennis in relatie tot de omvang van ervaring in medische diagnostiek. Feltovich et al. postuleren dat de kennisorganisatie van een noviet drie kenmerken heeft: 1. De kennisorganisatie wordt gedomineerd door de leerstofordening uit de basisvakken uit de opleidingsfase; 2 . In deze organisatie is er slechts in geringe mate sprake van verwijzingen naar of verbindingen tussen de verschillende lijnen in de hiërarchie; 3. De ken- 
nis zelf is nog niet nauwkeurig. Onder dat laatste punt wordt verstaan dat de kennis over de symptomen die wordt gebruikt in de klinische hypothese-vorming onvoldoende begrensd is. Daarentegen is voor de diagnostiek een kennis-organisatie in de vorm van 'prototypische ziektekennis" onontbeerlijk. Daarvan is sprake als de kennis is georganiseerd in 'ziekte-modellen' die de pathofysiologie van zielktes specificeren en een verzameling klinische symptomen bevatten die de patiënt zou kunnen vertonen tijdens het onderzoek. De omvang van deze verzameling ziektemodellen vereist een hiërarchische organisatie in niveaus. Het bovenste algemene niveau bevat de ziekte-categorieèn waarbij één categorie meerdere ziektes bevat die klinische overeenkomsten hebben. Afzonderlijke ziekten komen voor op een middenniveau in de hiërarchie om zich vervolgens af te splitsen in allerlei varianten, het derde niveau, waarin deze afzonderlijke ziekten zich kunnen manifesteren. In de differentiatie op het derde niveau spelen subtiele verschillen (anatomisch, fysiologisch) of secundaire kenmerken een rol (ernst van de klacht, leeftijd van de patiënt, etc.). Het belang van een op de praktijk toegesneden kennis-organisatie is evident. In de hierboven besproken onderzoeken (o.a. Chi et al., 1981, 1982) kwam naar voren dat de probleemrepresentatie gestuurd wordt door een initiële categorisatie van de probleeminformatie. In het medisch domein zal hierbij gebruik worden gemaakt van concepten die ontleend zijn aan deze ziektemodellen. De verschillen tussen novieten en experts zullen dus mede bepaald worden door de organisatie van de benodigde kennis. De ordening van de medische kennis in ziektemodellen is het product van de ontwikkeling waarin de klinische ervaring en reflectie daarop een dominante rol spelen.

Ook Boshuizen (1989) gaat uit van een ontwikkeling naar een hiërarchische ordening van de kennis van ziektes in drie niveaus. Op het eerste niveau is de inhoud van de afzonderlijke medische basisvakken aanwezig. Op het tweede niveau is er sprake van 'ziektescripts'. De praktijkgerichte organisatie van de kennis op het tweede niveau concretiseert Boshuizen in drie componenten: 1. 'enabling conditions': kennis van factoren die een aandoening kunnen veroorzaken (leeftijd, geslacht, beroep, risicogedrag, etc.); 2 . 'faults': kennis van de aandoeningen zelf (concepten afkomstig uit de basisvakken op het eerste niveau); 3. 'consequences': kennis van symptomen waaronder de verstoring zich klinisch manifesteert (gegevens uit lichamelijk onderzoek en laboratorium-onderzoek). Op het derde niveau van de organisatie bevindt zich episodische kennis welke wordt opgedaan in de contacten met concrete patiënten of simulaties in de opleiding. Centraal in deze sordening van kennis staan 'ziektescripts'. Aanwijzingen voor het bestaan van deze scripts vindt Boshuizen in een aantal experimenten. In een reproductie-taak werd geconstateerd dat de proefpersonen met meer ervaring 
de verwerkte informatie reproduceerden in een vaste volgorde die bepaald zou worden door de structuur van de kennis die was geactiveerd tijdens de informatieverwerving. Meer ervaren personen beschreven eerst de enabling conditions en daarna de consequences. In een volgend experiment liet Boshuizen zien dat de expert zijn diagnostische hypothesen stelt op basis van de klacht en een aantal patièntgebonden kenmerken (= enabling conditions). Daarentegen gingen de novieten uit van de op dat moment bekende symptomen ( $=$ consequences). Boshuizen spreekt in dit verband van de aanwezigheid van een 'geconditionaliseerd kennisbestand'. De structurele organisatie van de kennis waarin enabling conditions een rol spelen bevordert de snelheid en toepassingsgerichtheid van het denkproces.

Uit de onderzoeken van Feltovich et al. en Boshuizen in het medisch domein wordt aldus duidelijk dat de kennis die wordt gebruikt in het diagnostiseren weliswaar in eerste instantie wordt verworven binnen de context van op zichzelf staande vakgebieden maar dat deze kennis onder invloed van het gebruik in de praktijk wordt geïntegreerd tot kennis over ziekten die gediagnostiseerd worden. Feltovich spreekt van 'ziektemodellen' en Boshuizen doelt op hetzelfde fenomeen met de term 'ziektescripts'. Beide auteurs benadrukken de hiërarchische ordening van kennis. De aanwezigheid van een dergelijke ordening is het resultaat van individuele ontwikkeling waarbij ervaring met de praktijk van het beroep een cruciale rol speelt.

In de discussie naar aanleiding van het kennisactivatie-experiment in Hoofdstuk 4 werd aangekondigd dat de samenhang tussen kennis en probleemoplossen benaderd zou worden vanuit de ontwikkeling van vakgebonden kennis naar geïntegreerde kennis over aandoeningen van de patiënt. Een fysiotherapeut staat voor soortgelijke vragen als de arts bij de vaststelling van de aandoening in het onderzoek van de patiënt. De kennis die daarbij wordt gebruikt is weliswaar herleidbaar tot strikt vakgebonden kennis, echter een praktijkgerichte ordening van deze kennis zal deze vakgrenzen doorbreken tot samenhangende kennis. Ziekten en aandoeningen in de diagnostiek in het medisch en paramedisch domein zijn de concretisering van de probleemcategorieën waarvan eerder sprake was in de algemene bespreking van de interactie tussen waarneming en kennis in de vorming van een probleemrepresentatie. Geen enkel onderdeel van de kennis in het geheugen zal een geisoleerd leven leiden. Immers, herinnering veronderstelt dat concepten in een denkproces met elkaar verbonden worden. In die zin zal iedere deskundige in elk domein zijn kennis op eigen wijze georganiseerd hebben. Dit betekent echter niet dat bepaalde verbindingen niet de voorkeur hebben. Een efficiënte verbinding tussen concepten voor gebruik in de diagnostische praktijk zijn de categorieën van aandoeningen. Het feit dat kennis uit verschillende vakgebieden wordt geïntegreerd tot samenhan- 
gende kennis op een hoger niveau is niet het enige kwalitatieve kenmerk waarop de kennis van een expert verschilt met die van een noviet. Boshuizen karakteriseert zoals gezegd het geheel aan praktisch bruikbare kennis als een geconditionaliseerd kennisbestand. In algemene zin komt de conditionalisering van kennis aan de orde in de leertheorie van Anderson, Greeno, Kline \& Neves (1981), Anderson $(1982,1983)$ en Neves en Anderson (1981). Evenals Boshuizen ontlenen ook Hassebrock en Johnson (1986) hun inzichten over de ontwikkeling van expertise aan de algemene $A C T^{*}$-leertheorie $e^{2}$ van Anderson. De ontwikkeling van kennis verloopt in verschillende fasen. Volgens Anderson ondergaat de kennis in de verschillende fasen van dat leerproces een fundamentele verandering: 1 . In de zogenaamde declaratieve fase wordt basiskennis verworven. Indien de kennis in deze fase van de ontwikkeling wordt toegepast worden algemene methoden toegepast op concepten. Deze concepten moeten worden gevonden in het geheugen en geschikt worden gemaakt voor verwerking in het denkproces. Zoeken en interpreteren van concepten en regels zijn in deze fase van de individuele kennisontwikkeling belangrijke activiteiten. 2 . In de compilatiefase wordt de kennis bewerkt tot procedures waarbij het accent verschuift van het zoeken en interpreteren van declaratieve kennis naar het direct toepassen van procedures. Deze procedures zijn het resultaat van de ervaring waarin twee processen werkzaam zijn (Anderson, 1987, p. 197):

a. proceduralisatie: kennis in declaratieve vorm wordt getransformeerd naar 'als-dan-regels' (procedures) die kennis toepasbaar maken onder vastgestelde condities; als A (conditie) dan B (actie).

b. compositie: afzonderlijke en elkaar vaak opvolgende procedures worden na vaak gebruikt te zijn samengevat tot macro-producties: als-A-dan-B en als-B-dan-C wordt bijvoorbeeld als-A én B-dan-C, enz.

Deze twee processen in de ontwikkeling van de kennis zijn verantwoordelijk voor de toename van de snelheid en doeltreffendheid in het handelen van de expert. De conditionele samenvoeging van afzonderlijke kenniselementen in productieregels, die als én geheel onderdeel zijn van het denkproces, reduceert de kans op fouten omdat het werkgeheugen minder zwaar wordt belast. De compositie van verschillende productieregels tot samengestelde verkorte productieregels dragen eveneens bij aan deze kenmerken van expertise.

${ }^{2} \mathrm{ACT} *$ is een theorie over de basisprincipes van het cognitieve systeem. De letters ACT staan voor Adaptive Control of Thought (Anderson, 1983). 
Samenvattend zijn in de benadering van de samenhang tussen kennis en probleemoplossen vanuit het perspectief van de ontwikkeling van kennis de volgende punten van belang: De opbouw van de probleemrepresentatie wordt beinvloed door selectieve waarneming en categorisatie van de probleeminformatie. Deze selectieve waarneming wordt gestuurd door de relevante kennis die daartoe wordt geactiveerd. De mate waarin deze kennis geactiveerd kan worden is afhankelijk van haar organisatie. Deze theorie wordt ondersteund door onderzoeksresultaten afkomstig uit een groot aantal verschillende domeinen. Deze onderzoeken vertonen veel overeenstemming in object en methode van gegevensverzameling. De overeenstemming in onderzoeksobject tussen de verschillende domeinen betreft de analyse van de probleemrepresentatie en de interactie tussen probleemrepresentatie en geactiveerde kennis. Ten aanzien van de onderzoeksmethode komt de overeenstemming tot uitdrukking in het toepassen van reproductie-taken waarin bestudeerd werd welke informatie wordt waargenomen en hoe deze informatie wordt verwerkt tot een probleemrepresentatie. De conclusies van de onderzoekers wijzen in dezelfde richting: de kwalitatieve verschillen in de kenmerken van de kennis (organisatie, abstractie) zijn bepalend voor de mate van succes in het uitvoeren van probleemoplossingstaken. De bespreking van de onderzoeken binnen het expert-noviet paradigma werd afgesloten met een korte schets van de cognitieve ontwikkelingstheorie van Anderson. In deze theorie wordt specifiek aandacht besteed aan de veranderingen die de individuele kennis ondergaat onder invloed van ervaring. De empirische ondersteuning van deze ontwikkelingstheorie binnen het expertnoviet paradigma wordt echter ontleend aan de combinatie van gegevens (bijvoorbeeld de juistheid van de diagnose en structurele kenmerken van de onderliggende kennis) van verschillende personen met een verschillend ontwikkelingsniveau. Indien de juistheid van een diagnose echter verklaard kan worden uit de kwaliteit van de gebruikte kennis zal dit verband niet alleen tussen groepen - zoals in het expert-noviet paradigma - maar ook binnen groepen gevonden moeten kunnen worden. In de volgende paragraf zal hierop nader worden ingegaan.

\section{Goede en zwakke probleemoplossers: het verband tussen kennis en probleemoplossen binnen groepen van gelijk ervaringsniveau}

Tegenover de grote hoeveelheid en variatie van onderzoekingen naar het verband tussen kennis en probleemoplossen binnen het expert-noviet para- 
digma vormt de hoeveelheid aandacht voor ditzelfde onderzoeksobject binnen groepen van een homogeen (ontwikkelings-)niveau een schril contrast. De inzichten over de verbanden tussen kennis en probleemoplossen worden, zoals gezegd, ontleend aan onderzoek onder sterk verschillende groepen. Om een duidelijker inzicht te krijgen in de causale verbanden tussen de kwaliteit van kennis en probleemoplosvaardigheid is echter ook onderzoek nodig naar verschillen binnen betrekkelijk homogene groepen. Immers, voor het beroepsvoorbereidend onderwijs is het noodzakelijk dat inzicht wordt verkregen in de oorzaken van verschillen in vaardigheid tot het uitvoeren van taken die alan de orde komen in de latere beroepsuitoefening.

Een voorbeeld van onderzoek naar verschillen binnen homogene groepen is het onderzoek van De Jong (1986) in het natuurkundig domein, in het bijzonder 'elektriciteit \& magnetisme'. De Jong (1986) heeft de volgende bezwaren tegen het expert-noviet paradigma: 1 . De definitie van een expert en een noviet wisselt nogal over de verschillende onderzoeken. 2. Ten onrechte wordt verondersteld dat groepen van een verschillend ontwikkelingsniveau in dezelfde mate homogeen zijn. De Jong verwacht dat de verschillen tussen de experts onderling kleiner zijn dan tussen de novieten onderling.

Zoals aan het begin van deze paragraaf reeds is vastgesteld is het aantal onderzoeken naar de kennisafhankelijkheid van probleemoplossen binnen homogene groepen, waarbij de probleemoplosvaardigheid als criteriumvariabele werd gehanteerd, beperkt in omvang. Een literatuur-onderzoek met raadpleging van daarin gevonden verwijzingen leverde de volgende resultaten op:

Ekwo en Loening-Baucker (1979) onderzochten de vaardigheid in het oplossen van klinische problemen en de aard van de informatie die hierbij gebruikt werd onder derdejaars medische studenten. Goede probleemoplossers bleken gegevens te verzamelen met een hogere informatie-waarde en minder risico voor de patiënt. Bovendien was er bij de goede probleemoplossers sprake van een meer efficiënt gebruik van beschikbare gegevens. Samenvattend kon dus geconcludeerd worden dat ook binnen een groep proefpersonen van gelijk ontwikkelingsniveau verschillen constateerbaar zijn in de informatieverwerking en dat deze verschillen samenhingen met de vaardigheid in probleemoplossen.

Finegold en Mass (1985) onderzochten leerlingen uit het voortgezet onderwijs die deelnamen aan een cursus natuurkunde. Leerkrachten wezen op basis van de schoolvorderingen goede en zwakke probleemoplossers aan die niet verschilden in de mate van kennisbeheersing. Alle leerlingen kregen een aantal natuurkunde-vraagstukken voorgelegd en werden gevraagd bij het oplossen hiervan hardop te denken. Finegold en Mass (1985) zagen 
de volgende hypothesen bevestigd: 1. Goede probleemoplossers gebruiken in sterkere mate de juiste en meer exacte concepten in de omzetting van de probleemtekst in natuurkundige redeneringen. 2. Goede probleemoplossers plannen hun oplossing vollediger en gedetailleerder voor de uitvoering dan zwakke probleemoplossers. Onder verwijzing naar het verschil tussen novieten en experts geven de onderzoekers aan dat probleemoplossers hun geheugen raadplegen ten aanzien van de aanwezigheid van oplossingen voor verwante problemen. 3. Goede probleemoplossers lossen het probleem sneller op. 4. Goede probleemoplossers besteden meer tijd aan probleem-analyse en planning dan zwakke probleemoplossers. 5. Goede probleemoplossers redeneren met meer domeinspecifieke concepten dan zwakke probleemoplossers.

Uit de resultaten van het onderzoek van Finegold en Mass blijkt dus opnieuw, maar nu binnen een groep van gelijk ontwikkelingsniveau, dat er sprake is van een verband tussen de selectie van informatie en de kwaliteit van de probleemoplossing. Uit het feit dlat in hun protocollen blijkt dat de probleemoplossers de aangeboden probleeminformatie vergelijken met reeds gekende oplossingen kan worden afgeleid dat de categorisatie van de informatie en de activatie van specifieke kennis naww met elkaar zijn verweven. De kwalitatieve verschillen in de, tijdens het probleemoplossen, geactiveerde kennis die een rol spelen binnen het expert-noviet paradigma lijken dus ook een rol te spelen binnen 'homogene' groepen. Opvallend in dit verband is het feit dat Finegold en Mass (1985) twee hypothesen moesten verwerpen die betrekking hadden op niet-domeingebonden kennis. Goede probleemoplossers maakten niet meer gebruik van algebraïsche manipulaties en evalueerden en controleerden hun oplossingen niet veelvuldiger, anders gezegd: goede probleemoplossers maakten niet meer gebruik van strategische kennis.

Ook Mayer (1982) onderzocht het verschil binnen een groep leerlingen in het herkennen en gebruik van probleemcategorieën, in dit geval bij algebra-vraagstukken. Hij constateerde dat er aanzienlijke verschillen aanwezig waren in het onthouden van de tekst van de opgaven. Dit gegeven werd gezien als een bevestiging van het vermoeden dat de leerlingen verschillen ten aanzien van kennis van bepaalde probleemcategorieën. In een tweede experiment werd de proefpersonen gevraagd zelf algebra-problemen te construeren. Uit het feit dat een meerderheid binnen de groep problemen construeerde van een frequent voorkomend type werd de conclusie getrokken dat leerlingen gevoelig żijn voor het leren van probleemcategorieën.

Mayer (1985) constateerde in een onderzoek naar tekstbestudering en studievaardigheden dat goede en zwakke probleemoplossers niet verschillen in het onthouden van descriptieve feiten of regels maar wel verschillen in 
het herinneren van verklarende tekstpassages. In dit onderzoek is van belang dat de goede probleemoplossers kennelijk in de bestudering van nieuwe teksten specifieke voorkennis activeerden die aansloot bij de verklarende tekstpassages.

Uit de hierboven besproken onderzoeken naar verschillen in de vaardigheid van probleemoplossen binnen groepen van een gelijk ontwikkelingsniveau kan worden afgeleid dat het onderscheid tussen goede en zwakke probleemoplossers samengaat met een verschil in verwerking van de probleeminformatie. In de verklaring van dit verschil in informatieverwerking wordt verwezen naar een mogelijk verschil in kwalitatieve kenmerken (aard en structuur) van de gebruikte kennis. Echter geen der onderzoeken die zijn besproken bevat een direct onderzoek naar deze kwalitatieve kenmerken van de kennis in bijvoorbeeld een contrast-vergelijking tussen goede en zwakke probleemoplossers. Een uitzondering hierop vormt het reeds eerder genoemde onderzoek van De Jong (1986). Hij wijdde zijn dissertatie-onderzoek geheel aan de kenmerken van goede en zwakke probleemoplossers binnen een groep eerstejaars studenten van de Technische Hogeschool. Daarin maakte hij een onderscheid in vier soorten kennis: kennis van probleemsituaties, declaratieve, procedurele en strategische kennis. In een eerste experiment werd de experimentele groep een oplosstrategie geleerd. De resultaten van dit experiment lieten zien dat de aanwezigheid van strategische kennis (kennis van de methoden hoe een probleem moet worden opgelost) niet leidde tot betere probleemoplossingen van nieuwe taken. De conclusie werd getrokken dat domeinspecifieke kennis een sterkere rol speelt in probleemoplossen dan andersoortige kennis. In een tweede onderzoek werd in het betreffende vakgebied, elektriciteit \& magnetisme, nagegaan of de mate waarin studenten hun kennis hebben georganiseerd in probleemschemata samenhangt met hun prestaties op tentamens. Een probleemschema wordt gedefinieerd als "een afgepaste hoeveelheid kenniselementen die sterk met elkaar samenhangen binnen de cognitieve structuur van een probleemoplosser en die betrekking heeft op één categorie van problemen' (De Jong, 1986, pag. 36). De Jong constateerde dat studenten met een hoog tentamenciffer hun kennis meer volgens probleemschemata hadden georganiseerd dan studenten met een laag tentamencijfer. Daaruit werd de conclusie getrokken dat de wijze van organisatie van kennis in het geheugen samenhangt met de mate van succes bij het oplossen van problemen. Tenslotte werd in een derde onderzoek de "klassieke' reproductie-taak uitgevoerd: na een korte bestuderingstijd moest een probleembeschrijving gerecionstrueerd worden. Daarbij bleek dat goede probleemoplossers deze taak beter uitvoerden dan zwakke probleemoplossers en dat eerstgenoemden 
de kennis van probleemsituaties beter konden koppelen aan voor de oplossing relevante declaratieve en procedurele kennis.

\section{Hypothesen}

De besproken onderzoekingen binnen het expert-noviet paradigma kenmerken zich door een nadruk op de wijze waarop een probleemrepresentatie tot stand komt gedurende het proces van probleemoplossen. Binnen dit paradigma werd de probleemrepresentatie meestal onderzocht door de proefpersonen de gepresenteerde probleeminformatie achteraf te laten reconstrueren. Uit de analyse van deze reconstructies bleek dat experts deze taak beter uitvoerden dan novieten. Dit verschil in geheugenprestatie van beide groepen wordt verklaard uit een verschil in kennis die wordt geactiveerd tijdens de analyse van de probleeminformatie. Zo vonden Patel \& Frederiksen (1984) dat ervaren artsen bij de reproductie van een beschrijving van een patiënt meer exact gelijke proposities reproduceerden dan beginnende artsen. Ook De Jong (1986) liet zijn proefpersonen, echter nu in een homogene groep, een probleembeschrijving reproduceren. Hij constateerde dat goede probleemoplossers deze taak beter uitvoerden. Ook in het hierna te bespreken onderzoek zal de probleeminformatie schriftelijk worden gepresenteerd aan de proefpersonen. $\mathrm{Na}$ het formuleren van de probleemoplossing zal de proefpersonen worden gevraagd alles te vertellen wat men onthouden heeft van de probleemtekst. De bestuderingstijd van de probleemtekst wordt daarbij doelbewust kort gehouden om de eventueel te vinden verschillen te kunnen toeschrijven aan de geactiveerde kennis in de probleemanalyse en niet aan memoriseren. De protocollen van de proefpersonen zullen daarna geanalyseerd worden om de volgende hypothese te toetsen:

\section{Hypothese 1}

Bij een goede oplossing van het probleem wordt meer probleeminformatie onthouden dan bij een foute oplossing.

$\mathrm{Bij}$ de analyses van de verschillen in probleemrepresentatie tussen experts en novieten werd ook duidelijk dat laatstgenoemden andere informatie selecteerden dan de experts. Zo vonden Coughlin \& Patel (1986) dat novieten relevante en irrelevante informatie identiek verwerkten terwijl experts vooral belangrijke, kritische, informatie onthielden. Ekwo \& Loening-Baucker constateerden onder derdejaars medische studenten dat de goede pro- 
bleemoplossers in een simulatie gegevens verzamelden met een hogere informatiewaarde. De reconstructieprotocollen zullen derhalve ook worden geanalyseerd op de aard van de informatie die deze bevat. De teksten die de proefpersonen zullen bestuderen bevatten een aantal kritische informatieeenheden die aansluiten bij de waarschijnlijkheidsdiagnose over een specifieke aandoening die moet worden geformuleerd als probleemoplossing.

Indien de kennis over deze aandoening actief was tijdens de probleemanalyse mag verwacht worden dat bij een goede oplossing de probleemrepresentatie meer kritische informatie bevat. De volgende hypothese dient daarbij als uitgangspunt voor de toetsing:

\section{Hypothese 2}

Bij een goede oplossing van het probleem wordt belangrijker probleeminformatie onthouden dan bij een foute oplossing.

De bevestiging van deze hypothese betekent dat het formuleren van de goede probleemoplossing geen toevalstreffer is maar verklaarbaar is uit de geactiveerde kennis over een aandoening. De vraag die vervolgens aan de orde komt is waarom de proefpersonen verschillen in de mate van kennisactivatie. Alle volgende hypothesen zullen in dat verband betrekking hebben op de aard en de structuur van de gebruikte kennis in de probleemoplossingen.

Zoals in de bespreking wan de onderzoekingen reeds is gezegd zal de probleemoplosser de voorgelegde probleeminformatie analyseren, interpreteren en samenvoegen tot een probleemrepresentatie in termen van een specifieke aandoening. Dit proces is afhankelijk van het gemak waarmee de kennis over deze aandoening kan worden geactiveerd. In het onderzoek werden de proefpersonen daarom onderzocht op hun vermogen om spontaan, dus zonder aanwijzingen, kennis over een aandoening te activeren. Dit gebeurde door de proefpersonen de vraag te stellen "Vertell alles wat je weet over ...". De antwoorden op deze vraag werden op band geregistreerd en achteraf voor nadere analyse in een protocol uitgeschreven. Deze procedure is ontleend aan Schmidt, Boshuizen en Hobus (1988). Met deze procedure wordt de omvang van de kennis in een bepaalde categorie van de kennisorganisatie (de genoemde aandoening in de recall-opdracht) vastgelegd. Daarbij wordt vastgesteld hoeveel fysiotherapeutische concepten geactiveerd worden. Het aantal concepten dat zal worden geactiveerd zal bepaald worden door de organisatie van de kennis. De volgende hypothese zal worden getoetst in de analyse van de kennisprotocollen: 
Hypothese 3

Bij een goede oplossing van het probleem wordt een rijker kennisbestand geactiveerd dan bij een foute oplossing.

Indien we de organisatie van kennis voorstellen als een netwerk van concepten zal deze organisatie een beperkt aantal centrale concepten bevatten die als knooppunt fungeren voor de overige concepten. Patil, Szolovits en Schwartz (1984) veronderstellen dat voor het causaal begrijpen en interpreteren van ziektes in de medische diagnostiek een begrippenkader wordt gebruikt dat verschillende diepteniveaus kent. Zoals Finegold en Mass (1985) in een homogene groep vaststelden dat goede probleemoplossers met meer domeinspecifieke concepten redeneerden zal ook in dit onderzoek worden nagegaan of er een samenhang bestaat tussen de juistheid van de probleemoplossing en de mate van activatie van centrale concepten. Om dit verband te kunnen onderzoeken is een objectief referentiekader nodig voor de onderlinge vergelijking van de protocollen van de proefpersonen. Als vergelijkingsmaatstaf werd gekozen voor een handboek dat veel gebruikt wordt in de fysiotherapeutische praktijk (Winkel, Fisher \& Vroege, 1984). In dit boek worden de meest voorkomende aandoeningen in de fysiotherapie in extenso beschreven. Analyse van deze teksten resulteerde in een lijst van concepten die werden geschematiseerd. Aan deze schema's werden de centrale concepten ontleend op basis van hun positie in het netwerk. De volgende hypothese zal worden getoetst:

\section{Hypothese 4}

Bij een goede oplossing van het probleem worden meer relevante concepten over een specifieke aandoening geactiveerd dan bij een foute oplossing.

Zoals gezegd wordt de omvang en de mate van relevantie van de geactiveerde concepten geïnterpreteerd als een aanwijzing voor een betere organisatie van deze kennis. De schema's die werden geconstrueerd voor de toetsing van hypothese 4 , teneinde de relevantie van concepten te bepalen in de kennisstructuren over specifieke aandoeningen, kunnen ook gebruikt worden voor een matching met de geschematiseerde protocollen van de proefpersonen. Boshuizen (1989) gebruikte deze methode om de mate van organisatie van kennis van novieten en experts te vergelijken. Deze vergelijking had als resultat dat met een toename van het expertise-niveau de concepten van de individueel gereproduceerde kennis overeenkomstig een ideaaltypisch model met elkaar verbonden waren. De vergelijking van de geschematiseerde protocollen van de proefpersonen met een geschematiseer- 
de tekst van een fysiotherapeutisch handboek geeft, in aanvulling op hypothese 4, een indruk of de kennis over een specifieke aandoening ook modelmatig is georganiseerd. De verbindingen tussen de concepten in de geschematiseerde protocollen worden vergeleken met de verbindingen tussen de concepten van het ideaaltypisch model. Met deze vergelijking wordt het aantal "identieke paden" vastgesteld. Reeds eerder werd gezegd dat het proces van informatieverwerking in probleemoplossen en leren vergelijkbaar zijn. Immers, ook in een probleem wordt nieuwe informatie gepresenteerd. In een onderzoek naar leerprocesen vonden Domaracki en Ohnmacht (1986) dat de variantie in het begrijpen van nieuwe informatie niet kan worden verklaard uit de hoeveelheid voorkennis maar uit de structuur van de voorkennis. Meyer en McConkie (1.973) voorspelden dat de kans dat concepten worden herinnerd bepaald wordt door de positie van deze concepten in een logische structuur. Dit geeft aanleiding tot de volgende hypothese:

\section{Hypothese 5}

Bij een goede oplossing van het probleem beschikt de probleemoplosser over een kennisbestand dat meer identieke relaties bevat, in vergelijking met een ideaaltypisch model, dan bij een foute oplossing.

De inleidende bespreking van dit hoofdstuk over de ontwikkeling van kennis eindigde met de theorie van Anderson over de verschillende fasen in de ontwikkelingsgang. De laatste hypothese waarin het verschil in kwallitatieve kenmerken van kennis over aandoeningen tussen goede en zwakke probleemoplossers zal worden getoetst wordt ontleend aan deze theorie. Indien concepten zijn opgenomen in regels met een antecedent en een consequent is het mogelijk deze concepten te gebruiken in als-dan redeneringen ten behoeve van de bevestiging of uitsluiting van bepaalde conclusies in het diagnostiseren (Gomez en Chandrasekaran, 1984). In dat geval spreken we over het gebruik van procedurele kennis. Patel en Groen (1986) ontdekten dat experts, in hun geval cardiologen, over meer procedurele kennis beschikken en beschreven hun kennis in dat verband als een 'causaal netwerk'. In de ACT*-leertheorie van Anderson (1983) betekent de aanwezigheid van procedurele kennis dat de individuele cognitieve ontwikkeling van dat kennisdomein een fase verder is. In de analyse zal een verband worden gezocht tussen de mate van proceduralisatie van de geactiveerde kennis en de juistheid van de probleemoplossing. Voor deze analyse werden alle proposities of samenhangende proposities uit de kennisprotocollen die een causaal karakter hebben uitgeschreven in de vorm van antecedent en consequent. $\mathrm{Na}$ deze analyse zal de volgende hypothese worden getoetst: 


\section{Hypothese 6}

Bij een goede oplossing van het probleem beschikt de probleemoplosser over meer procedurele kennis dan bij een foute oplossing.

\section{Studie 4: Onderzoek naar het verband tussen kwalita- tieve kenmerken van kennis en de juistheid van de pro- bleemoplossing}

\section{Methode}

\section{Proefpersonen}

Aan deze vierde studie werd door 9 proefpersonen deelgenomen. Allen waren afkomstig van éen opleiding en participeerden op vrijwillige basis. Deelname aan het onderzoek werd beloond met een kleine vergoeding. De proefpersonen waren derdejaars studenten fysiotherapie en stonden kort voor het begin van hun praktijkleerperiode. In deze fase van het curriculum wordt de theoretische basisworming afgerond.

\section{Meetinstrumenten}

In deze studie werden vier metingen verricht van de volgende, onderling gerelateerde aspecten: 1 . de accuraatheid van de diagnose; 2 . de probleemrepresentatie; 3 . de aanwezigheid van kennis en 4 . de kwalitatieve kenmerken van de kennis.

De accuraatheid van de diagnose werd gemeten met vier korte probleemtaken in tekstvorm die zijn overgenomen uit de tweede studie en slechts op onderdelen werden aangepast. Als voorbeeld ${ }^{3}$ van deze probleemtaak geldt de volgende tekst:

Opdracht: geef aan de hand van onderstaande gegevens de belangrijkste waarschijinlijkheidsdiagnose.

Het onderzoek levert de volgende gegevens op:

Een man van 42 jaar heeft sinds 4 weken last van schouderpijn links. De klachten zijn ontstaan nadat hij zijn schoonzoon is gaan helpen met het voegen van het nieuwe huis. Dit was voor hem ongewoon werk.

${ }^{3}$ Vanwege de inhoudelijke verwantschap tussen de verschillende metingen zullen alle volgende voorbeelden in de bespreking van de methode en resultaten ontleend worden aan deze probleemtaak. 
Bij inspectie is er sprake van een versterkte thoracale kyfose, een wersterkte cervicale lordose, en naar woren geschoven hoofd, een schouderhoogstand links en de schoudertop is rechts ronder dan links.

Actief bewegingsonderzoek linkerschouder:

Tijdens de abductie beweegt de linkerscapula eerder mee t.o. $\mathrm{v}$, de abductie rechts. Vanaf $80^{\circ}$ abductie wordt de beweging pijnlijk. De pijn is gelokaliseerd th.v. de regio deltoidea. De pijn gaat gepaard met uitstraling tot halverwege de laterale zijde wan de bowenam. De pijn wordt gedurende de abductie heviger en blift tot het einde wan de beweging aanwezig. Aan het einde van de beweging neemt de pijn wat af.

De exorotatic is links $\pm 10^{\circ}$ beperkt t.o.v. rechts, er is geen pijn. Bij de overige bewegingen zijn er geen bijzonderheden.

Passief bewegingsonderzoek linkerschouder:

De abductie is links $\pm 5^{\circ}$ beperkt t.o.v. rechts. Er is een pijnlijk eindgevoel. De pijin wordt gelokaliseerd in de regio deltoidea. De exorotatie is links $\pm 5^{\circ}$ beperkt t.o. w. rechts. En er is geen pijm.

Isometrische weerstandstesten:

Bij een isometrische abductie vanuit de anatomische 0-stand blijkt links de kracht minder t.o.v. rechts, en er wordt een scherpe stekende pijn aangegeven in de regio deltoídea en laterale zijde van de bovenarm. Na ontspannen verdwijnt de pijn geleidelijk. Bij uitwoering van deze test onder gleno-humerale tractie blijwen de bevindingen gellik. Bij een isometrische abductie vanuit $90^{\circ}$ gleno-humerale abductie blijkt links de kracht minder. Er wordt tijdens de contractie minder pijn aangegeven t.o.v. de abductie vanuit de anatomische 0 -stand.

De waarschijnlijkheidsdiagnose bij deze probleemtaak is "een teno-periostale tendinitis van de musculus supraspinatus". De proefpersonen schreven de probleemoplossing op een antwoord-formulier dat werd ingenomen.

De probleemrepresentatie werd gemeten via een opdracht tot reproductie. $\mathrm{Na}$ de afsluiting van de probleemtaak en na het verwijderen van de tekst werd de proefpersonen gevraagd alles te vertellen wat men zich herinnerde van de gelezen tekst. Deze antwoorden werden op band geregistreerd om achteraf geprotocolleerd en geanalyseerd te kunnen worden in vergelijking met de gepresenteerde probleemtekst.

De aanwezigheid van kennis die relevant werd geacht voor het formuleren van de diagnoses werd gemeten in de kennistoets waarbij de items dezelfde vorm hadden als in voorgaande drie studies. In totaal waren negen parallel-items voor vier probleemtaken in de kennistoets opgenomen. Deze negen items waren ondergebracht in een toets van 75 kennis-items. Dit om de kans te minimaliseren dat proefpersonen zich de betreffende items zouden herinneren bij het oplossen van de problemen (de toets werd voor de problemen afgenomen). Bij de probleemtaak die hierboven als voorbeeld werd gegeven behoren de volgende kennisitems. 
Buj een isometrische weerstandstest abductie van de schouder vanuit de anatonische 0 -stand wordt pijn aangegeven in de regio deltoidea. Bij uitwoering van deze test onder glenohumerale tractie blijven de bevindingen gelijk.

- Deze pijn wordt dus niet veroorzaakt door de bursa subacromio-deltoidea. (juist)

Bij een actieve abductie van de schouder wordt vanaf 80 graden de beweging pijnlijk. De pijn neemt toe in het verdere bewegingsverloop en neemt voor het betreiken van de eindgrens weer af.

- Tijdens deze beweging is er sprake van een painful-arc. (juist)

De $\mathrm{m}$. deltoüdeus kan geen painful-arc veroorzaken. (juist)

De tweede manier waarop de aanwezige kennis van de proefpersonen werd gemeten, en in die zin wijkt deze studie af van de voorgaande drie studies, was een 'free-recall'-taak. De kennis die in de drie bovenstaande items is verwoord omvat de meest relevante kennis waarmee de waarschijnlijkheidsdiagnose van de probleemtaak kan worden geformuleerd. Deze kennis is echter opgenomen in een groter geheel van kennis over een specifieke aandoening. Zoals geformuleerd werd in de discussie bij de voorgaande studie zal deze kennis dus geactiveerd kunnen worden door de probleemoplosser indien de aandoening in kwestie wordt overwogen. Eenmaal geactiveerd zal dus deze kennis een rol krijgen in het zoeken naar ondersteuning van de waarschijnlijkheidsdiagnose die wordt overwogen. Of de probleemoplosser erin slaagt deze kennis 'spontaan' te activeren moet worden vastgesteld in een andere kennis-meting dan de gebruikelijke toetsvorm. Daarvoor werd de 'free-recall'-taak gekozen. De aandoening die gediagnostiseerd moest worden in de voorbeeld-probleemtaak was een "teno-periostale tendinitis van de musculus supraspinatus". De proefpersonen kregen de volgende opdracht: "Vertel alles wat je weet over een teno-periostale tendinitis van de musculus supraspinatus". De antwoorden van de proefpersonen op deze vragen werden op band geregistreerd om achteraf geprotocolleerd en geanalyseerd te kunnen worden op de kwalitatieve kenmerken die een voorwaarde zijn voor activatie van kennis (omvang procedurele kennis en organisatie van kennis).

Samenvattend wordt in deze studie de samenhang tussen de juistheid van de bereikte probleemoplossing (criteriumvariabele) en de volgende variabelen onderzocht: de omvang van de probleemrepresentatie (hypothese 1 ), de relevantie van de probleemrepresentatie (hypothese 2 ), de omvang van de geactiveerde kennis (hypothese 3), de relevantie van de geactiveerde 
kennis (hypothese 4), en structurele kenmerken van de geactiveerde kennis (hypothesen 5 en 6).

\section{Procedure}

Alle proefpersonen werden individueel benaderd. Onder leiding van een ervaren fysiotherapeut werden de metingen verricht met de volgende procedure: Eerst werd de schriftelijke kennistoets afgenomen. Deze toets bevatte 75 items waarvoor maximaal 45 minuten beschikbaar was. Vervolgens werden de probleemtaken gepresenteerd. Voor iedere probleemtaak werd 1 minuuit leestijd gegeven om de tekst te bestuderen, daama moest de tekst weggelegd worden en de oplossing worden opgeschreven. De tijdlimiet van 1 minuut leestijd werd gehanteerd om te voorkomen dat de tekst letterlijk werd gememoriseerd. $\mathrm{Na}$ het opschrijven van de probleemoplossing werd gedurende korte tijd door de proefleider de aandacht van de proefpersoon afgeleid om het korte-termijn geheugen van de probleemoplosser te "schonen' van de letterlijke probleeminformatie. Daama werd de meting verricht wan de probleemrepresentatie van het zojuist afgesloten probleem. Daarbij werd door de proefleider de bandrecorder gestart en verzocht hij de proefpersoon alles te vertellen wat men zich herinnerde van de zojuist bestudeerde probleemtekst. Deze registratie van de probleemrepresentatie is dus indirect. Gelet op de korte bestuderingstijd waarbij het memoriseren van tekst voorkomen wordt, wordt de reproductie van de tekst bepaald door de probleemrepresentatie tijdens de probleem-analyse. Op deze wijze werden alle vier probleemtaken gepresenteerd. $\mathrm{Na}$ de afhandeling van de probleemtaken werd een pauze ingelast van ongeveer vijftien minuten. Vervolgens werd de kennis geregistreerd met de 'free-recall procedure'. De proefleider startte de bandrecorder en verzocht de proefpersoon alles te vertellen wat men wist over een bepaalde aandoening. De genoemde aandoening betrof telkens de aandoening die de kern had moeten vormen van een goed geformuleerde waarschijnlijkheidsdiagnose bij de vier voorafgaande probleemtaken. In deze fase werd dus de kennis geregistreerd die geactiveerd zou kunnen worden indien de proefpersoon de genoemde aandoening als waarschijnlijkheidsdiagnose zou hebben gegenereerd tijdens het diagnostiseren.

De hierboven geschetste procedure werd gebruikt voor de verzameling van de gegevens die gebruikt zouden worden in de analyse voor de hypothesen-toetsing. Na de kennistoets en voorafgaande aan de presentatie van de eerste feitelijke probleemtaak werd geoefend met ér probleemtaak en de daarbij behorende free-recall metingen ten aanzien van de probleemreprešentatie en de kennis over de aandoening. Deze gegevens zijn buiten de analyse gehouden. De totale sessie duurde ongeveer twee en een half uur voor én proefpersoon. 


\section{Analyse}

De kennistoets en de waarschijnlijkheidsdiagnoses van de vier probleemtaken werden beoordeeld op basis van een vooraf geconstrueerde antwoordsleutel. In de hypothesen wan deze studie worden de verbanden onderzocht tussen de juistheid van de probleemoplossing en kenmerken van de probleemrepresentatie enerzijds en tussen de juistheid van de probleemoplossing en de kwalitatieve kenmerken van de probleemrelevante kennis van de probleemoplosser anderzijds. Daar negen proefpersonen ieder vier problemen kregen voorgelegd zijn 36 diagnoses $(9 \times 4)$ beschikbaar die als 'goed' of 'fout' konden worden geclassificeerd. In Tabel 1 staan de resultaten van de beoordeling van de probleemtaken. Daarin betekent code 0 dat een fout antwoord werd gegeven en code 1 een goed antwoord. Eveneens is in deze tabel te zien (laatste twee kolommen) dat proefpersonen met een gelijke kennis-score, overeenkomstig met de resultaten uit de voorgaande studies, in sterke mate kunnen verschillen in probleemoplosvaardigheid.

Tabel 1: Overzicht resultaten probleemtaken en totaal-scores op de kennistoets

\begin{tabular}{ccccccc} 
Proefpersoon & \multicolumn{9}{c}{ Probleem-taak nr. } & $\begin{array}{c}\text { Totaal } \\
\text { casus } \\
(0-4)\end{array}$ & $\begin{array}{c}\text { Totaal } \\
\text { kennis } \\
(0-9)\end{array}$ \\
& 1 & 2 & 3 & 4 & & \\
1 & 0 & 0 & 0 & 1 & 1 & 4 \\
2 & 0 & 1 & 1 & 1 & 3 & 6 \\
3 & 0 & 1 & 0 & 0 & 1 & 6 \\
4 & 1 & 1 & 0 & 1 & 3 & 7 \\
5 & 0 & 0 & 0 & 0 & 0 & 6 \\
6 & 0 & 1 & 0 & 1 & 2 & 5 \\
7 & 1 & 0 & 1 & 1 & 3 & 3 \\
8 & 0 & 1 & 0 & 0 & 1 & 7
\end{tabular}

Totaal

$\begin{array}{llll}2 & 5 & 2 & 6\end{array}$

Van de 36 beoordeelde problemen werden 15 probleemoplossingen als 'goed' beoordeeld en 21 probleemoplossingen als 'fout'. In de hierna volgende analyse zijn uiteraard relaties tussen kennis en probleemoplossen binnen personen onderzocht. De resultaten zijn getotaliseerd over alle problemen. 
Dit is gedaan om het onderscheidingsvermogen van de gebruikte statistische procedures te vergroten. Daarnaast leek een contrast-analyse tussen "goede" en "zwakke" probleemoplossers een minder voor de hand liggende benadering dan een contrastanalyse tussen goede en foute probleemoplossingen omdat over de vier problemen heen zich onder de proefpersonen, getuige de resultaten in Tabel 1 , geen duidelijk 'goede' subgroep en een duidelijk ' $z$ wakke' subgroep aftekendê.

De analyse van de afzonderlijke variabelen geschiedde als volgt:

Probleemrepresentatie; $\mathrm{Bij}$ de 'free-recall' opdracht "Vertel alles wat je onthouden hebt van de zojuist bestudeerde tekst" werd, zoals gezegd, de gereproduceerde tekst op de band opgenomen en achteraf uitgeschreven in een protocol. De vergelijking van de protocol-tekst van de probleemoplosser met de originele tekst geschiedde door de telling van het aantal gereproduceerde informatie-eenheden van de originele tekst.

Zowel de originele tekst als het protocol van de probleemoplosser werden verdeeld in zinnen om vervolgens verder verdeeld te worden in proposities. Dit zijn zinsgedeelten die een onderwerp-gezegde combinatie bevatten (Schmidt, 1982). Tot dusver is er dus sprake van een taalkundige analyse. Er moest echter rekening worden gehouden met de aanwezigheid van synoniemen of parafraseringen in de protocollen die, ondanks de afwijking van de originele tekst, toch in de analyse moeten worden opgenomen. Het doel $1^{3}$ van de analyse betrof de vastlegging van de inhoud van de probleemrepresentatie en niet de mate van letterlijke tekstreproductie in vergelijking tot de aangeboden tekst. Daarom werd de tekst-analyse afgerond met de bepaling van de informatie-eenheden die zouden dienen als vergelijkingsmaatstaf. Daartoe werden soms de onderscheiden proposities nog verder verdeeld, andersom was het ook mogelijk dat bepaalde proposities werden samengevoegd.

Als woorbeeld van deze analyse bevat het volgende kader een tekstfragment dat verdeeld werd in zes informatie-eenheden.

- Dit is ook in overeenstemming met de in Hoofdstuk 1 beschreven variabiliteit in probleemoplosgedrag binnen proefpersonen. Of iemand een probleem goed oplost is vooral een functie van de aard van het probleem en kenmerken van de probleemoplosser die aan het specifieke probleem gebonden zijn.

De uitgebreidheid van een tekst-analyse is in zijn algemeenheid afhankelijk van het doel van de onderzoeker (Meyer, 1975). 
Tekst:

Bij een isometrische abductie vanuit de anatomische 0-stand blijkt links de kracht minder t.0.V. rechts, en er wordt een scherpe stekende pijn aangegeven in de regio deltoïdea en laterale zijde van de bovenarm. Na ontspannen verdwijnt de pijn geleidelijk.

\section{Informatie-eenheden:}

5 bij een isometrische abductie vamuit de anatomische 0 -stand

E

(*) blijkt links de kracht minder t.o.w. rechts

- (*) en er wordt een scherpe stekende pijn aangegeven

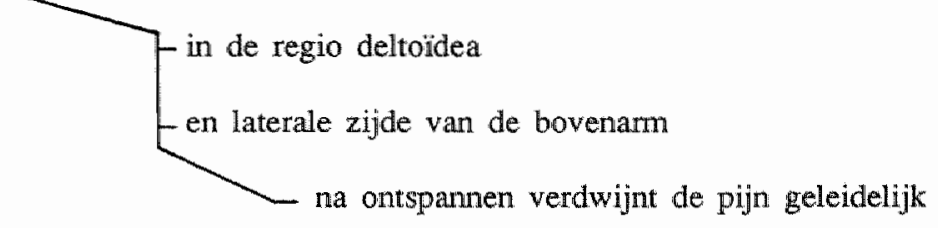

* = kritische informatie

De veronderstelling dat er sprake is van een verschil in probleemrepresentatie bij goede en foute probleemoplossingen is getoetst door vergelijking van de percentages gereproduceerde informatie-eenheden.

Niet alle informatie-eenheden in de originele tekst hebben een gelijk gewicht in relatie tot de goede probleemoplossing. In de tweede hypothese werd verondersteld dat bij een goede probleemoplossing belangrijker informatie wordt gereproduceerd dan bij een foute probleemoplossing. Voorafgaande aan de toetsing van deze hypothese werden in de tekst-analyse een aantal 'kritische' informatie-eenheden onderscheiden die kenmerkend zijn voor de aandoening die gediagnostiseerd moet worden. Deze zijn in het voorbeeld van de tekst-analyse hierboven gemarkeerd met een *. Deze kritische informatie-eenheden zullen in ruimere mate aanwezig moeten zijn in de probleemrepresentaties van proefpersonen met een goede probleemoplossing. Deze hypothese werd getoetst door vergelijking van de percentages gereproduceerde kritische informatie-eenheden.

Omvang geactiveerde kennis; Voor de toetsing van de overige hypothesen (3-6) zijn de protocollen van de bandopnamen geanalyseerd die het resultaat vormen van de vraag: "Vertel alles wat je weet over een tenoperiostale tendinitis van de musculus supraspinatus" (of andere aandoeningen 
bij de overige probleemtaken). Als anallyse-eenheid in deze protocollen werd gekozen voor 'fysiotherapeutische concepten'. Alle fysiotherapeutische concepten werden in het protocol gemarkeerd. Voor de toetsing van hypothese 3 werd het totaal aantal geactiveerde concepten berekend.

Relevantie geactiveerde kennis; In hypothese 4 wordt verondersteld dat bij een goede probleemoplossing meer relevante concepten worden geactiveerd. Voor deze weging van de geactiveerde kennis is een zogenaamd norm-model benodigd van de kennis over de specifieke aandoening. Op basis van een fysiotherapeutisch handboek met betrekking tot diagnostiek (Winkel et al., 1984) is voor elke casustekst een ideaaltypisch model geconstrueerd. Het handboek in kwestie vindt brede erkenning in de fysiotherapeutische beroepspraktijk en kan gekarakteriseerd worden als een standaardwerk in de fysiotherapeutische opleidingen (Ronteltap, Dobbelaere \& Rameckers, 1986). Zorgvuldige tekst-analyse van de beschrijvingen van de specifieke aandoeningen in dit handboek leverde voor elke casus een reeks van anatomische, kinesiologische en pathologische concepten op die gezamenlijk alle relevante kennis over de specifieke aandoening in de fysiotherapeutische praktijk omvat. Voor de voorbeeld-casus in deze studie betrof dat de volgende concepten:

I Algemene kennis over tendopathie/tendinitis:

- degeneratie pees

- zone verminderde doorbloeding

- complicatie: ruptuur

- diverse stadia van aandoening ( $1 \mathrm{t} / \mathrm{m} 6)$

lokalisatie:

- pees-insertie/teno-periostaal

- pees lichaam

- overgang van spier naar pees

oorzaken:

- vascularisatie pees neemt af bij stijgen leeftijd

- abnormale belasting/overbelasting

- cortico-steroiden (injecties)

- anabole steroiden (injecties)

II Anatomische/kinesiologische kennis over musculus supraspinatus:

- origo: fossa suprascapularis

- insertie: mberculum majus

- insertie: bovenste facet

- functie: abductie

- functie: exorotatie 
III Kennis over tendinitis musculus supraspimatus (pathologie en onderzoek):

- pees met krirische zone

- degeneratie

- wringing-out phenomenon

- painful-arc

- tussen $60^{\circ}$ en $120^{\circ}$ abductie

- weinig ruimte tussen kop en dak van het schoudergewricht

- komt veel voor bij werpers en zwemmers

- los-laat pijn

- weerstandstest abductie pijnlijk

- passieve elevatie eindstandig pijnlijk

- d.d. bursitis

- palpatie pijnlijk

- weerstandstest exorotatie pijnlijk

lokalisatie:

- oppervlakkig teno-ossaal

- diep teno-ossaal

Deze reeks van concepten is geordend in 3 categorieèn die verschillen in de mate van belangrijkheid voor de diagnostiek van de specifieke aandoening. De kennis over de aandoening 'teno-periostale tendinitis musculus supraspinatus' bevat in eerste instantie kennis over een tendinitis (peesontsteking) in het algemeen (categorie D), ongeacht de lichaamsregio waarin deze zich manifesteert. Een peesontsteking kan bijvoorbeeld gelokaliseerd zijn ter hoogte van de aanhechting van de pees aan het bot (concept: tenoperiostaal, categorie I). Door zijn algemeenheid is deze kennis van gering belang voor onderzoek en therapie van een bijzondere tendinitis (van de musculus supraspinatus). Als men in deze situatie op de hoogte is waar de spier aan het bot vastzit (bijvoorbeeld concepten: bovenste facet/tuberculum majus, categorie II) kan men op basis van deze lokalisatie van de aanhechting afleiden dat de pees voelbaar is (concept: palpatie pijnlijk, categorie III) en een pijnlijk traject kan veroorzaken (concept: painful-arc, categorie III). Samengevat: indien een proefpersoon wordt gevraagd zijn kennis te activeren over een bijzondere aandoening zullen concepten worden geactiveerd die verschillen in de mate van specificiteit en relevantie. In de toetsing van hypothese $4 \mathrm{zal}$ worden onderzocht of een goede probleemoplossing samenhangt met een activatie van kennis die overeenkomt met kennis uit de meer specifieke categorieën II en III. Deze indeling van concepten in categorieën werd dus gebruikt bij alle vier probleemtaken. Omdat het absolute aantal activeerbare concepten per aandoening verschilt worden relatieve scores gebruikt: percentages geactiveerde concepten van één categorie per aandoening. 
Structuuranalyse van geactiveerde kennis; In hypothese 5 wordt onderzocht of er een verband bestaat tussen de juistheid van de probleemoplossing en de conceptuele structuur van de geactiveerde kennis. Voorafgaande aan de toetsing van deze hypothese zijn de hierboven genoemde concepten geschematiseerd in een ideaaltypisch model (Figuur 1, pag. 103). Dezelfde procedure is ook uitgevoerd met de protocollen van de proefpersonen. In totaal zijn 36 schema's van de proefpersonen geconstrueerd en vergeleken met de vier ideaaltypische modellen. De analyse-eenheid voor de toetsing van hypothese 5 is het aantal identieke paden overeenkomstig het ideaaltypisch model, tussen de concepten van het geschematiseerde protocol.

Ontwikkelingsniveau van geactiveerde kennis; In hypothese 6 wordt onderzocht of er een verband bestaat tussen de juistheid van de probleemoplossing en het ontwikkelingsniveau van de daarbij geactiveerde kennis. Dit gebeurt door in de kennisprotocollen het aantal proposities te tellen die procedurele kennis bevatten. De hypothese is getoetst door vergelijking van de gemiddelde hoeveelheden procedurele proposities behorende bij de kennis bij goede en foute probleemoplossingen.

\section{Resultaten}

\section{Probleemrepresentatie}

Door de proefpersonen de opdracht te geven de teksten van de problemen te reconstrueren werden de gegevens verzameld over de probleemrepresentatie bij de casus. De probleemrepresentatie is het resultaat van de verwerking van de probleeminformatie onder invloed van de geactiveerde kennis in de probleemanalyse. In de eerste hypothese wordt voorspeld dat bij een goede probleemoplossing een completer beeld is gevormd van de probleemtaak. De protocollen van de proefpersonen werden verdeeld in informatieeenheden die vergeleken werden met de informatie-eenheden uit de oorspronkelijke probleemtekst. De veronderstelling dat bij een goede probleemoplossing meer informatie wordt onthouden werd getoetst door vergelijking van de gemiddelde percentages gereproduceerde oorspronkelijke informatieeenheden bij foute en goede oplossingen over 4 probleemtaken. De resultaten van deze vergelijking staan in Tabel 2 (zie pag. 104). 
Figur 1: Ideaaltypische structuur van conceptem

corticosteroilden anabole steroïden injecties

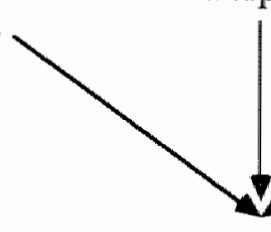

overbelasting

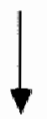

wringing out
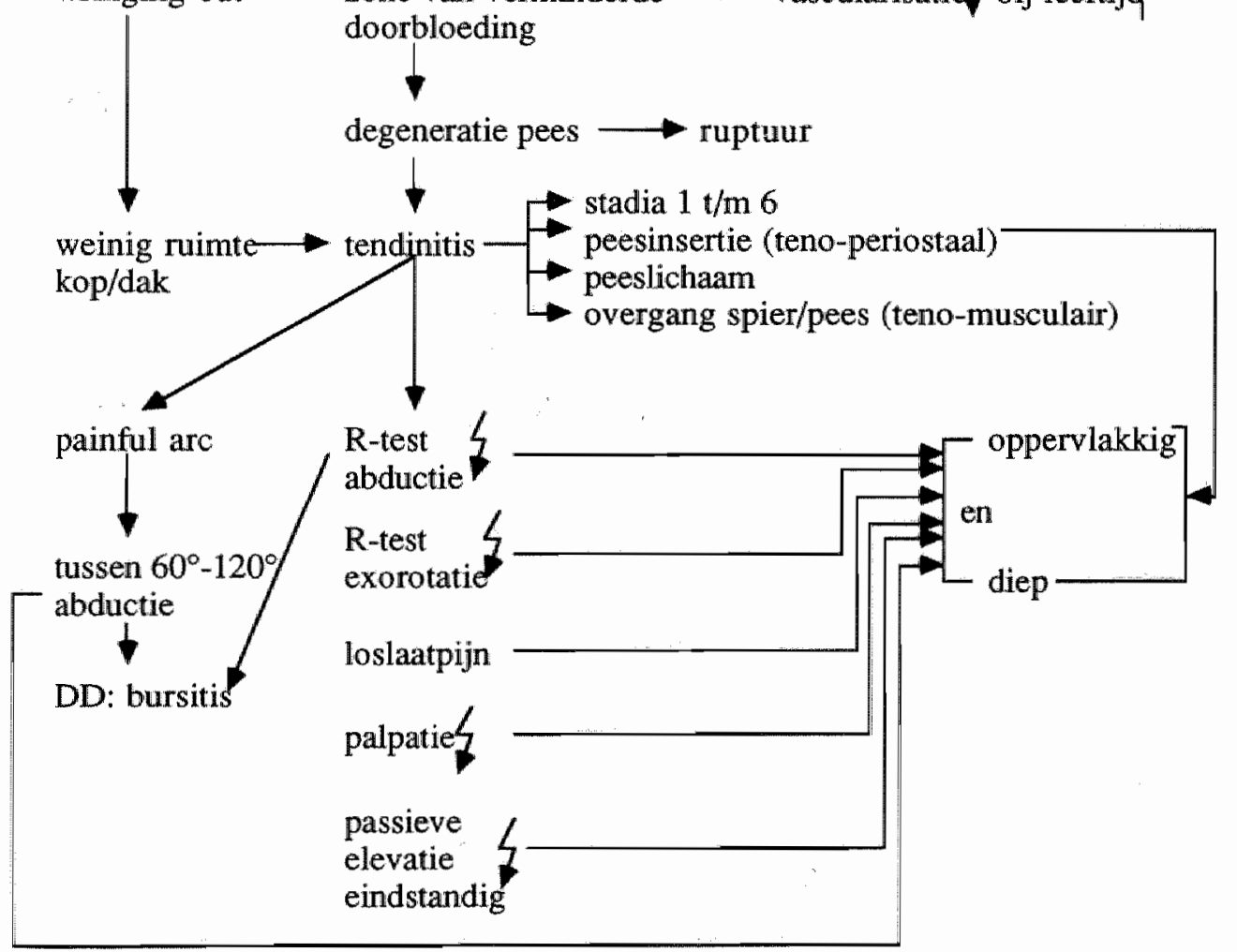
Tabel 2: Percentages gereproduceerde informatie-eenheden over 4 probleemtaken

\begin{tabular}{lcccc} 
& Gerniddelde & S.D. & Range & N \\
\cline { 2 - 4 } foute oplossingen & 37.76 & 11.51 & $13-63$ & 21 \\
goede oplossingen & 44.13 & 16.45 & $21-77$ & 15
\end{tabular}

Uit deze gegevens bleek dus dat bij een goede probleemoplossing meer informatie werd gereproduceerd, echter de varianties binnen beide groepen oplossingen zijn te groot om een significant verschil te vinden: $t=1.2$, df $=34$, n.s.

Omdat de probleemrepresentatie van de probleemoplosser geen toevallige selectie vormt van de aangeboden probleeminformatie maar bovendien een weerspiegeling is van de geactiveerde kennis tijdens het probleemoplossen mag verwacht worden dat bij de goede oplossingen meer diagnostisch relevante informatie-eenheden worden gereproduceerd dan bij foute oplossingen. De teksten van de casus bevatten een aantal zogenaamde 'kritische informatie-eenheden" die, indien de relevante kennis was geactiveerd, oververtegenwoordigd moesten zijn in de protocollen bij de goede probleemoplossingen. Dit bleek ook het geval te zijn bij vergelijking van de gemiddelde percentages gereproduceerde kritische informatie-eenheden bij foute en goede oplossingen over 4 probleemtaken. De resultaten van deze vergelijking staan in Tabel 3.

Tabel 3: Percentages gereproduceerde kritische informatie-eenheden over 4 probleemtaken

Gemiddelde

S.D.

Range

N

foute oplossingen

goede oplossingen
33.81

60.4
21.1

30.4
0-80

$0-100$
21

15

De probleemrepresentaties bij de goede oplossingen bevatten significant meer diagnostisch relevante informatie $(t=3.1$, df $=34, p<.005)$. 


\section{Kennis over aandoeningen}

De kennis over aandoeningen die wordt gebruikt in de diagnostiek is samengesteld uit concepten die afkomstig zijn uit verschillende vakgebieden: anatomie, kinesiologie en pathologie. Indien de kennis uit deze verschillende vakgebieden geherstructureerd is in 'kennis over aandoeningen' zal de herkenning van deze aandoeningen in de praktijk sneller verlopen. Goed georganiseerde kennis zal vanwege de onderlinge relaties tussen de afzonderlijke concepten de benodigde activatie in gunstige zin bevorderen. Het aantal geactiveerde concepten is een indicatie voor de aanwezigheid van een passende conceptuele structuur in de vorm van geïntegreerde kennis over aandoeningen. De proefpersonen werd gevraagd alles te vertellen wat men wist over specifieke aandoeningen. Daarbij werden de antwoorden op deze vraag op band geregistreerd en werden de kennisprotocollen geanalyseerd. De veronderstelling dat bij een goede oplossing een rijker kennisbestand wordt geactiveerd is getoetst door vergelijking van de gemiddelde aantallen geactiveerde concepten bij foute en goede oplossingen over 4 probleemtaken. De resultaten van deze vergelijking staan in Tabel 4.

Tabel 4: Aantal geactiveerde concepten bij kennis over aandoeningen over 4 probleemtaken

\begin{tabular}{lcccc} 
& Gemiddelde & S.D. & Range & N \\
\cline { 2 - 4 } & & & \\
foute oplossingen & 16.71 & 7.4 & $4-29$ & 21 \\
goede oplossingen & 23.53 & 7.79 & $8-34$ & 15
\end{tabular}

Uit Tabel 4 blijkt dat de proefpersonen die het probleem goed oplosten in staat waren om spontaan meer kennis te activeren $(t=2.67, \mathrm{~d} f=34$, $\mathrm{p}<.05$ ). Hieruit kan worden afgeleid dat bij een goede probleemoplossing werd beschikt over meer geïntegreerde kennis over aandoeningen. De kennisprotocollen werden ook beoordeeld op de mate van relevantie van de geactiveerde concepten. Daarbij werd de geactiveerde kennis vergeleken met de kennis uit een veelgebruikt handboek in de fysiotherapeutische praktijk. Deze kennis uit het handboek wordt gebruikt als een ideaaltypisch model van bruikbare kennis in de probleemtaken. Van elk kennisprotocol werd het percentage aanwezige modelconcepten over twee categorieën berekend.

De veronderstelling dat bij goede oplossingen meer relevante kennis wordt geactiveerd, is getoetst door vergelijking van de gemiddelde percen- 
tages geactiveerde model-concepten bij foute en goede oplossingen over 4 probleemtaken. De resultaten van deze vergelijkingen staan in Tabel 5 en 6.

Tabel 5: Percentages geactiveerde modelconcepten voor de categorie 'anatomie en kinesiologie over 4 probleemtaken

$\begin{array}{lclll}\text { Gemiddelde } & \text { S.D. } & \text { Range } & \text { N } \\ & & & \\ \text { foute oplossingen } & 24.9 & 29.07 & 0-80 & 21 \\ \text { goede oplossingen } & 54.4 & 35.4 & 0-100 & 15\end{array}$

Tabel 6: Percentages geactiveerde modelconcepten woor de categorie 'pathologie en onderzoek' over 4 probleemtaken

\begin{tabular}{|c|c|c|c|c|}
\hline Gemiddelde & S.D. & Range & $\mathrm{N}$ & \\
\hline foute oplossingen & 16.33 & 16.96 & 0.57 & 21 \\
\hline goede oplossingen & 34.07 & 17.13 & $13-71$ & 15 \\
\hline
\end{tabular}

Samenvattend kan uit de toetsing van beide laatste hypothesen worden geconcludeerd dat bij een goede probleemoplossing niet alleen meer in omvang, maar ook meer relevante kennis wordt geactiveerd (categorie 'anatomie en kinesiologie': $t=2.74, d f=34, p<.01$; categorie 'pathologie en onderzoek': $\mathrm{t}=3.08$, $\mathrm{df}=34, \mathrm{p}<.01$ ).

In de volgende analyses werden de kwalitatieve kenmerken van de kennisprotocollen onderzocht. In de eerste plaats de structuur van de geactiveerde concepten. Daartoe werden alle protocollen geschematiseerd en werden deze schema's vergeleken met een schema van de ideaaltypische kennis uit het handboek dat ook werd gebruikt als basis voor de vergelijking in de vorige hypothese. Het aantal identieke relaties tussen concepten van geschematiseerd protocol en ideaaltypisch model werd geteld. De veronderstelling dat bij een goede probleemoplossing de kennis meer gestructureerd is overeenkomstig het ideaaltypisch model werd getoetst door middel van vergelijking van de gemiddelde hoeveelheid identieke relaties bij foute en goede 
oplossingen over 4 probleemtaken. De resultaten van deze vergelijking staan in Tabel 7 .

Tabel 7: Aantal identieke relaties overeenkomstig een ideaaltypisch model over 4 probleemtaken

\begin{tabular}{lcccc} 
& Gemiddelde & S.D. & Range & N \\
\cline { 2 - 4 } & & & & $0-8$ \\
foute oplossingen & 2.33 & 2.52 & $1-10$ & 21 \\
goede oplossingen & 5.07 & 2.74 & & 15
\end{tabular}

Uit Tabel 7 blijkt dat de kennis van de personen met een goede probleemoplossing beter is gestructureerd dan de kennis van de personen met een foute oplossing ( $t=3.1$, df $=34, p<.05$ ).

De laatste analyse van de kennisprotocollen betrof de mate van ontwikkeling van declaratieve kennis tot procedurele kennis. Een belangrijk kenmerk van het diagnostisch denkproces is het causale karakter: concepten zijn op een conditionele wijze met elkaar verbonden. In de protocol-analyses zijn alle conceptuele relaties in de vorm van 'antecedent' en 'consequent' geteld. Tot deze relaties werden gerekend: concepten die in het protocol met elkaar verbonden werden door verbindingswoorden als 'dus', 'omdat', 'doordat' en 'als' of door werkwoorden als 'zullen", "ontstaan', etc. De veronderstelling dat bij een goede probleemoplossing meer procedurele kennis aanwezig is werd getoetst door middel van vergelijking van de gemiddelde hoeveelheid procedurele propositics bij foute en goede oplossingen over 4 probleemtaken. De resultaten van deze vergelijking staan in Tabel 8.

Tabel 8: Aantal procedurele proposities over 4 probleemtaken

\begin{tabular}{lrrrr} 
& Gerniddelde & S.D. & Range & N \\
\cline { 2 - 4 } & & & & \\
foute oplossingen & 7.05 & 3.32 & $2-15$ & 21 \\
goede oplossingen & 10.07 & 4.25 & $1-17$ & 15
\end{tabular}

De kennisprotocollen bij de goede probleemoplossingen bevatten significant meer procedurele kennis $(t=2.39, \mathrm{df}=34, \mathrm{p}<.05$ ) waaruit dus kan wor- 
den geconcludeerd dat deze kennis verder is ontwikkeld tot bruikbare kennis in de diagnostiek.

\section{Discussie}

Uit de resultaten van de hier gerapporteerde studie blijkt dat personen met een goede of foute probleemoplossing verschillen in hun representatie van het probleem. Goede probleemoplossers verschillen in geringe mate ten aanzien van de compleetheid van de probleemrepresentatie maar verschillen daarentegen in sterke mate ten aanzien van de reproductie van diagnostisch relevante informatie. Omdat de probleemrepresentatie (selectie van informatie) tot stand komt onder invloed van de geactiveerde kennis tijdens de probleemanalyse is er dus in deze studie wél sprake van een invloed van voorkennis op probleemoplosvaardigheid. Dit in tegenstelling tot de voorgaande studies waarin dit verband niet gevonden kon worden. Er is echter een verschil in de aard van de kennismeting tussen deze studie en de voorgaande studies. In de eerste drie studies werd volstaan met een meting van de aanwezigheid van casusrelevante kennis in afzonderlijke items van een kennistoets. Daarin werd gevonden dat de aanwezigheid van relevante kennis een zwak verband vertoonde met de diagnose-scores. Ook in deze vierde studie bleek opnieuw dat het goed beantwoorden van de items uit de kennistoets geen garantie vormde voor het vinden van de juiste probleemoplossing. Immers, in Tabel 1 is te zien dat proefpersonen met een gelijke score op de kennisitems in sterke mate verschillen in probleemoplossen. In deze vierde studie werd de meting van kennis uitgebreid met een zogenaamde free-recall meting. In de laatstgenoemde procedure werd de proefpersonen gevraagd alles te vertellen over een aandoening van een patiënt. Op deze wijze kan worden vastgesteld of de casusrelevante kennis die in eerste instantie was verwerkt tot afzonderlijke items voor de kennistoets ook spontaan wordt geactiveerd bij de overweging van een specifieke waarschijnlijkheidsdiagnose. Deze procedure van kennismeting komt meer overeen met de gang van zaken tijdens het proces van probleemoplossen. Immers, de aangeboden probleeminformatie leidt tot de overweging van een waarschijnlijkheidsdiagnose waarna, tengevolge van deze overweging, alle concepten die deel uitmaken van deze geïntegreerde kennis over een aandoening kunnen worden gebruikt in de daaropvolgende redenering tot bevestiging van deze waarschijnlijkheidsdiagnose. De kennisafhankelijkheid van probleemoplossen moet aldus begrepen worden: de aanwezigheid van domeinspecifieke kennis is uiteraard essentieel maar niet voldoende. Aan- 
vullend moet worden voldaan aan de voorwaarde dat deze bruikbare kennis ook activeerbaar is. Om geactiveerd te kunnen worden is het noodzakelijk dat de kennis is geherstructureerd in kennis over diagnostiseerbare aandoeningen. Als voorbeeld van de kwalitatieve verschillen in kennis tussen proefpersonen bespreken wij de protocollen van de free-recall procedure van twee proefpersonen (proefpersoon 3: oplossing fout; proefpersoon 4: oplossing goed) die beiden twee van de drie relevante items uit de kennistoets goed beantwoordden en dus niet lijken te verschillen in de mate van aanwezigheid van bruikbare kennis.

\section{Proefpersoon 3: oplossing fout}

Vraag proefleider: Vertel alles wat je weet over een tenoperiostale tendinitis van de musculus supraspinatus.

\section{Proefpersoon:}

De weerstandstest zal dus pijnlijk zijn. ... Tenoperiostale overgang van de pees op de botaanhechting kan ontstaan door een overbelasting. ... De musculus supraspinatus gaat van de fossa supraspinata van het scapula naar het tuberculum majus op de humerus. Op welk vlak die aanhecht van het tuberculum majus weet ik niet. ... Ik dacht dat die pijnlijk kon zijn bij abductie, compressie, exorotatie.

\section{Proefpersoon 4: oplossing goed}

Vraag proefleider: Vertel alles wat je weet over een tenoperiostale tendinitis van de musculus supraspinatus.

\section{Proefpersoon:}

De musculus supraspinatus is een spier met als origo de fossa supraspinatus, die zich aan de achterzijde van het scapula bevindt, boven de spina. De insertie is het bovenste facet van het tuberculum majus op de humerus. Heeft als functie: abductie van de schouder. Als er nou door owerbelasting of door een trauma een scheurtje ontstaat teno-periostaal, of microtraumata... Het kan op een drietal manieren ontstaan. Het kan teno-periostaal diep zijn, het kan oppervlakkig zijn, of het kan een combinatie zijn. ... Dan krijg je ook verschillende klinische beelden. Bij een diep peesletsel zal de passieve elevatie eindstandig pijnlijk zijn. Bij een oppervlakkig peesletsel zal een painful-arc ontstaan. En bij een combinatie van die twee, diep en oppervlakkig, zal zowel een passieve ellevatie pijnlijk zijn, als een painful-arc. Zijn die beide niet aanwezig dan kan er nog een spierpeesovergang of een supraspinatus zijn. Die painful-arc wordt veroorzaakt doordat de pees van de supraspinatus wordt gecomprimeerd onder het dak van het acromion, tussen acromion en tuberculum majus. Het is vaak moeilijk 
den geconcludeerd dat deze kennis verder is ontwikkeld tot bruikbare kennis in de diagnostiek.

\section{Discussie}

Uit de resultaten van de hier gerapporteerde studie blijkt dat personen met een goede of foute probleemoplossing verschillen in hun representatie van het probleem. Goede probleemoplossers verschillen in geringe mate ten aanzien van de compleetheid van de probleemrepresentatie maar verschillen daarentegen in sterke mate ten aanzien van de reproductie van diagnostisch relevante informatie. Omdat de probleemrepresentatie (selectie van informatie) tot stand komt onder invloed van de geactiveerde kennis tijdens de probleemanalyse is er dus in deze studie wél sprake van een invloed van voorkennis op probleemoplosvaardigheid. Dit in tegenstelling tot de voorgaande studies waarin dit verband niet gevonden kon worden. Er is echter een verschil in de aard van de kennismeting tussen deze studie en de voorgaande studies. In de eerste drie studies werd volstaan met een meting van de aanwezigheid van casusrelevante kennis in afzonderlijke items van een kennistoets. Daarin werd gevonden dat de aanwezigheid van relevante kennis een zwak verband vertoonde met de diagnose-scores. Ook in deze vierde studie bleek opnieuw dat het goed beantwoorden van de items uit de kennistoets geen garantie vormde voor het vinden van de juiste probleemoplossing. Immers, in Tabel 1 is te zien dat proefpersonen met een gelijke score op de kennisitems in sterke mate verschillen in probleemoplossen. In deze vierde studie werd de meting van kennis uitgebreid met een zogenaamde free-recall meting. In de laatstgenoemde procedure werd de proefpersonen gevraagd alles te vertellen over een aandoening van een patiënt. Op deze wijze kan worden vastgesteld of de casusrelevante kennis die in eerste instantie was verwerkt tot afzonderlijke items voor de kennistoets ook spontaan wordt geactiveerd bij de overweging van een specifieke waarschijnlijkheidsdiagnose. Deze procedure van kennismeting komt meer overeen met de gang van zaken tijdens het proces van probleemoplossen. Immers, de aangeboden probleeminformatie leidt tot de overweging van een waarschijnlijkheidsdiagnose waarna, tengevolge van deze overweging, alle concepten die deel uitmaken van deze geïntegreerde kennis over een aandoening kunnen worden gebruikt in de daaropvolgende redenering tot bevestiging van deze waarschijnlijkheidsdiagnose. De kennisafhankelijkheid van probleemoplossen moet aldus begrepen worden: de aanwezigheid van domeinspecifieke kennis is witeraard essentieel maar niet voldoende. Aan- 
vullend moet worden voldaan aan de voorwaarde dat deze bruikbare kennis ook activeerbaar is. Om geactiveerd te kunnen worden is het noodzakelijk dat de kennis is geherstructureerd in kennis over diagnostiseerbare aandoeningen. Als voorbeeld van de kwalitatieve verschillen in kennis tussen proefpersonen bespreken wij de protocollen van de free-recall procedure van twee proefpersonen (proefpersoon 3: oplossing fout; proefpersoon 4: oplossing goed) die beiden twee van de drie relevante items uit de kennistoets goed beantwoordden en dus niet lijken te verschillen in de mate van aanwezigheid van bruikbare kennis.

\section{Proefpersoon 3: oplossing fout}

Vraag proefleider: Vertel alles wat je weet over een tenoperiostale tendinitis van de musculus supraspinatus.

Proefpersoon:

De weerstandstest zal dus pijnlijk zijn. ... Tenoperiostale overgang wan de pees op de botaanhechting kan ontstaan door een overbelasting. ... De musculus supraspinatus gaat van de fossa supraspinata van het scapula naar het tuberculum majus op de humerus. Op welk vlak die aanhecht van het tuberculum majus weet ik niet. ... Ik dacht dat die pijnlijk kon zijn bij abductie, compressie, exorotatie.

\section{Proefpersoon 4: oplossing goed}

Vraag proefleider: Vertel alles wat je weet over een tenoperiostale tendinitis van de musculus supraspinatus.

\section{Proefpersoon:}

De musculus supraspinatus is een spier met als origo de fossa supraspinatus, die zich aan de achterzijde van het scapula bevindt, boven de spina. De insertie is het bovenste facet van het tuberculum majus op de humerus. Heeft als functie: abductie van de schouder. Als er nou door overbelasting of door een trauma. een scheurtje ontstaat teno-periostaal, of microtraumata. ... Het kan op een drietal manieren ontstaan. Het kan teno-periostaal diep zijn, het kan oppervlakkig zijn, of het kan een combinatie zijn. ... Dan krijg je ook verschillende klinische beelden. Bij een diep peesletsel zal de passieve elevatie eindstandig pijnlijk zijn. Bij een oppervlakkig peesletsel zal een painful-arc ontstaan. En bij een combinatie van die twee, diep en oppervlakkig, zal zowel een passieve elevatie pijnlijk zijn, als een painful-arc. Zijn die beide niet aanwezig dan kan er nog een spierpeesovergang of een supraspinatus zijn. Die painful-arc wordt veroorzaakt doordat de pees van de supraspinatus wordt gecomprimeerd onder het dak van het acromion, tussen acromion en tuberculum majus. Het is vaak moeilijk 
om hem te differentien van een infraspinatus tendinitis. Ondat, $\ldots$ in het onderzoek worden de weerstandstesten abductie nogal eens verkeerd uitgevoerd. Dat ie de am dus in een relatieve exorotatie houdt wardoor dus de infraspinatus ook wordt getest. En doordat de infraspinatus direct onder de supraspinatus aanhecht op het tuberculum majus. Het zou dus ook een lokale pijn kurnen arngeven bij het bewegen ter hoogte wan het deltoï. Door die microtraumata is er dus een verkleving ontstaan van die supraspinatus. En die probeer je dus met een dwarse frictie los te krijgen.

Reeds bij een oppervlakkige optische analyse zal duidelijk zijn dat er eem groot verschil bestaat tussen beide proefpersonen in de mate van activatie van kennis over deze aandoening. In de eerste hypothese over het verband tussen kennis en de juistheid van de probleemoplossing werd verondersteld dat een goede probleemoplosser meer kennis kan activeren. Deze hypothese werd bevestigd. Bij een louter kwantitatieve analyse van een protocol in de vorm van het aantal geactiveerde concepten loopt men echter, ondanks het feit dat de voorkomende concepten bij herhaald noemen slechts én keer geteld worden, het risico dat concepten worden meegeteld die strikt genomen niet genoemd hoeven te worden. Immers associatief kan allerlei kennis worden geactiveerd die van secundair belang is voor de probleemoplossing. Daarom werden de verzamelingen concepten ook vergeleken met een verzameling concepten die onttrokken werd aan een tekst over deze aandoening in een veelgebruikt handboek in de fysiotherapeutische diagnostiek. Daarmee kwam een objectieve basis beschikbaar voor een kwalitatieve vergelijking van de geactiveerde kennis door de proefpersonen. In de tweede hypothese werd verondersteld dat een goede probleemoplosser meer relevante concepten zou activeren. Ook deze hypothese werd bevestigd. Vervolgens werden in twee hypothesen de factoren onderzocht die begunstigend werken op de activeerbaarheid van de aanwezige kennis. In de eerste plaats werden de kennisprotocollen van alle proefpersonen geschematiseerd en werden deze conceptuele structuren vergeleken met de conceptuele structuur van het model uit het handboek. In deze vergelijkende analyse werden de identieke relaties tussen de concepten van beide schema's geteld. In de hypothese werd verondersteld dat bij een goede probleemoplosser de kennisstructuur meer overeenkomsten vertoonde met de structuur van het model. De resultaten van deze analyse voor de beide bovenstaande protocollen staan in de volgende Figuren 2 en 3 (pag. 111 en 112). 
Figuur 2: Conceptuele structuur proefpersoon 3 (oplossing fout)
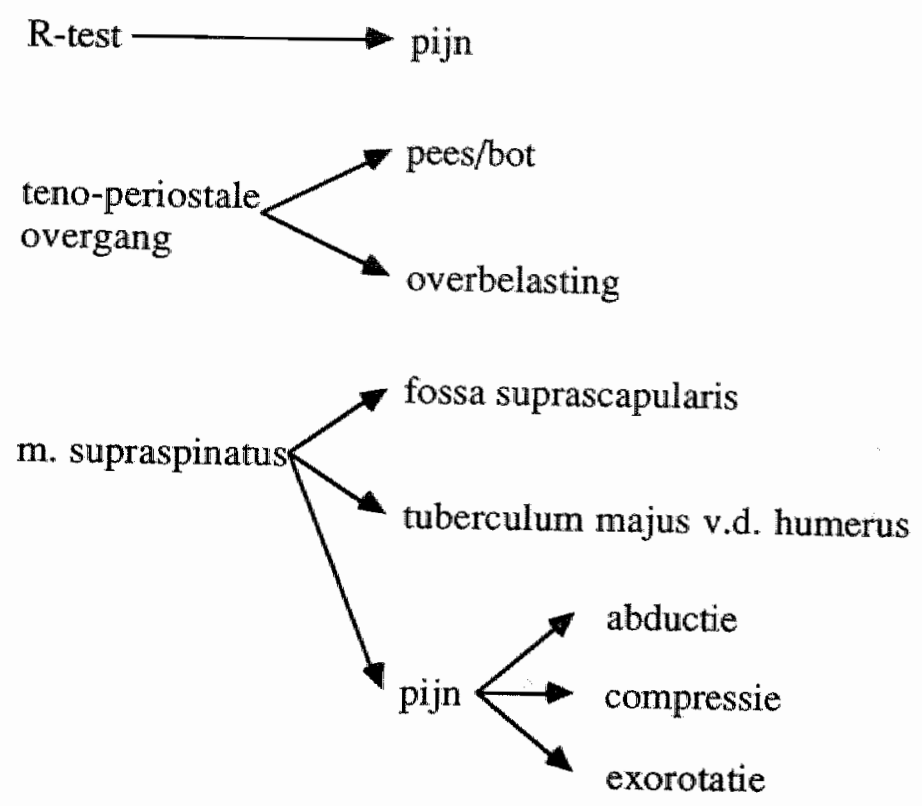

Vergelijking van de conceptuele structuren van beide proefpersonen bracht in de eerste plaats aan het licht dat proefpersoon 4 met de goede oplossing alle concepten met elkaar verbond ( 7 identieke relaties), in tegenstelling tot proefpersoon 3 waarvan het schema losse onderdelen bevat ( 3 identieke relaties). De hypothese dat goede probleemoplossers hun kennis beter georganiseerd hadden werd op basis van 36 van deze vergelijkingen bevestigd. Tenslotte werden de kennisprotocollen geanalyseerd vanuit het perspectief van de ontwikkeling van kennis. Indien concepten op conditionele wijze met elkaar verbonden zijn is de probleemoplosser in de gelegenheid om causale redeneringen op te nemen in het denkproces. De mate van conditionalisering van kennis werd vastgesteld door de hoeveelheid procedurele kennis in de protocollen. Deze procedurele kennis werd opgespoord door de relaties tussen concepten waarin sprake is van 'een 'antecedent' en 'consequent' afzonderlijk uit te schrijven. De protocollen van proefpersonen 3 en 4 brachten de volgende verschillen aan het licht (Tabellen 9 en 10, pag. 113). 
Figuur 3: Conceptuele structuur proefpersoon 4 (oplossing goed)

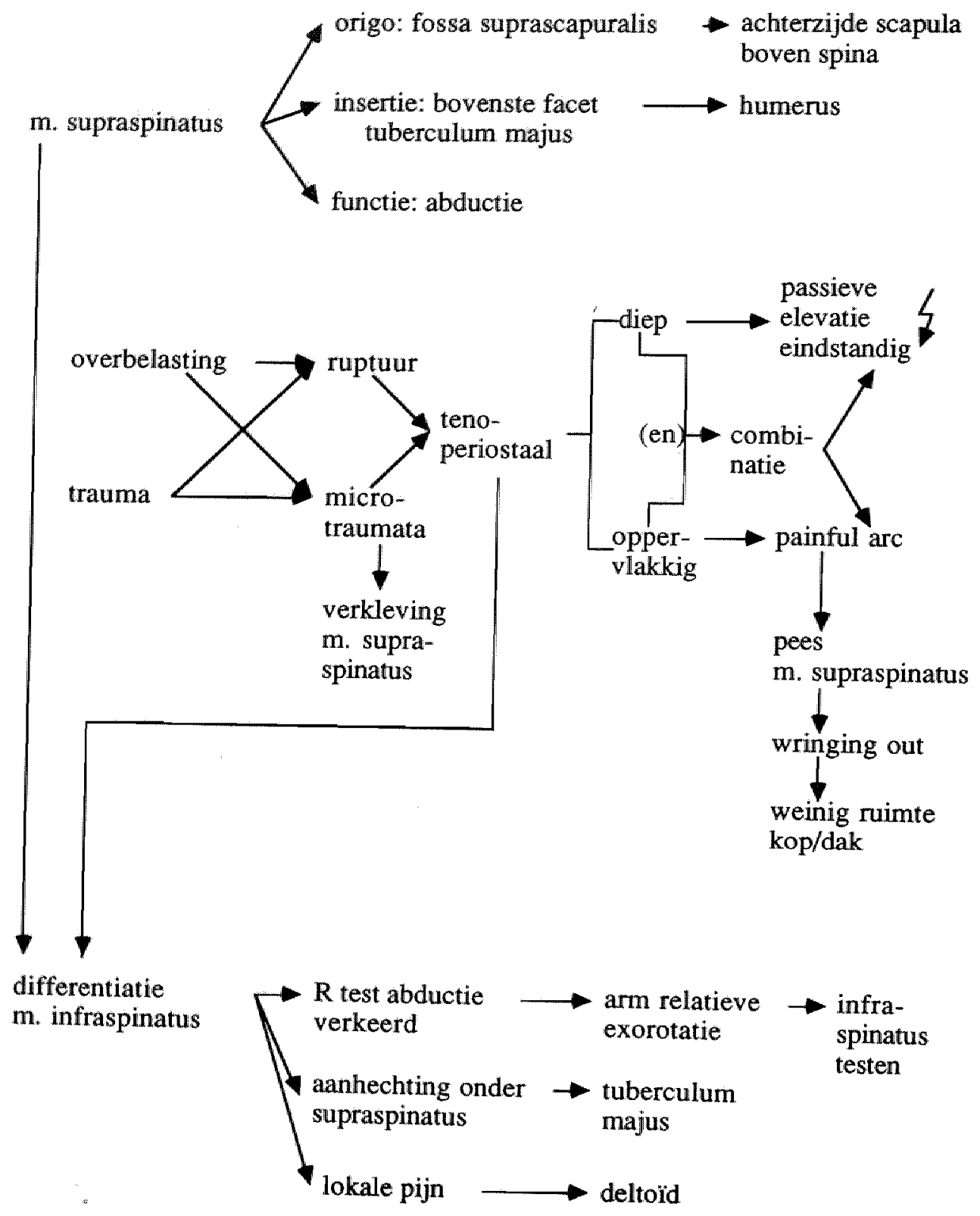


antecedent consequent teno-periostale tendinitis * weerstandstest pijnlijk teno-periostale tendinitis * pijn bij abductie teno-periostale tendinitis * pijn bij compressie teno-periostale tendinitis * pijn bij exorotatie overbelasting * teno-periostale overgang pees

Totaal: 5 procedurele proposities

Tabel 10: Procedurele kennis proefpersoon 4 met goede oplossing

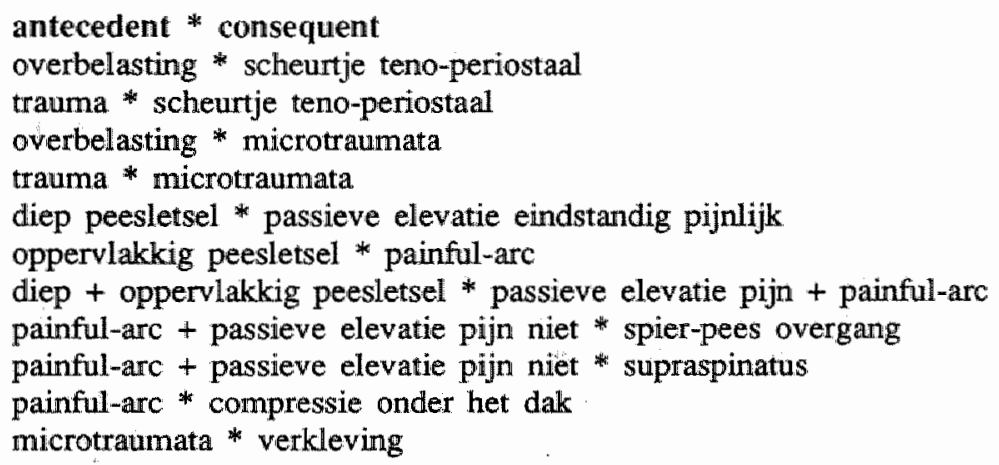

Totaal: 11 procedurele proposities

Deze analyse van de protocol-voorbeelden laat eveneens zien dat het verschil in geactiveerde kennis zich niet beperkt tot het aantal procedurele relaties tussen concepten. Het protocol van proefpersoon 4 met een goede oplossing bevat meer specifieke concepten die bovendien wisselend voorkomen in de antecedent en in de consequent. Dit geeft het protocol een meer 'redenerend' karakter in tegenstelling tot het protocol van proefpersoon 3 dat een meer 'beschrijvend' karakter heeft. Ook de hypothese met betrekking tot de grotere hoeveelheid procedurele kennis bij de goede probleemoplossers werd in de totaal-analyse bevestigd. 
Samenvattend kunnen op basis van deze studie ten aanzien van de kennisafhankelijkheid van probleemoplossen de volgende conclusies worden getrokken: De verbindende schakel tussen de domeinspecifieke kennis in het geheugen en de probleemoplosvaardigheid is de vorming van de probleemrepresentatie. Goede probleemoplossers blijken een betere probleemrepresentatie te vormen. De analyse van de probleemrepresentaties toonde namelijk aan dat deze representaties significant meer diagnostisch relevante informatie bevatten. Uit de bespreking van de resultaten van vergelijkend onderzoek tussen novieten en experts werd duidelijk dat de vorming van een probleemrepresentatie afhankelijk is van de interactie tussen waarneming en kennis. Dit is de reden voor een gedetailleerde analyse van de kwaliteit van de kennis van de probleemoplossers. Een analyse die verder gaat dan de vaststelling of de meest relevante kennis aanwezig is. De kennis die moest worden geactiveerd in de oplossing van de probleemtaken maakt deel uit van een groter geheel aan kennis over een specifieke aandoening van de patiënt. In deze studie activeerden de goede probleemoplossers niet alleen mér maar ook meer diagnostisch relewante kennis. De activatie van kennis wordt bepaald door twee factoren. In de eerste plaats blijken goede probleemoplossers te beschikken over een betere kennisorganisatie en in de tweede plaats is de kennis verder ontwikkeld: de verbindingen tussen de concepten hebben vaker een conditioneel karakter. Deze beide kwalitatieve eigenschappen van de domeinspecifieke kennis tonen aan dat de probleemoplosvaardigheid afhankelijk is van de ontwikkeling van vakgebonden kennis naar geïntegreerde kennis die direct bruikbaar is in de praktijk.

In alle studies van dit proefschrift stond de kennisafhankelijkheid van probleemoplossen centraal: succesvol probleemoplossen wordt bepaald door de kennis die in het probleem moet worden gebruikt. In de eerste twee studies bleek dat de aanwezigheid van de probleemrelevante kennis een onvoldoende voorwaarde is. De kennis moet ook beschikbaar zijn. Uit deze studie wordt mu duidelijk dat de mate waarin aanwezige kennis geactiveerd kan worden afhankelijk is van de organisatie van deze kennis. De integratie van kennis uit verschillende basisvakken in samenhangende kennis over specifieke aandoeningen manifesteert zich duidelijker bij de goede probleemoplossers. In dat verband is in de analyses van spontaan geactiveerde kennis getracht aan te tonen dat de verschillen tussen de protocollen bij goede en foute probleemoplossingen (aantal geactiveerde concepten en relevantie van geactiveerde concepten) samengaan met structurele verschillen in aanwezige kennis. Ook in de eerste drie studies werd reeds een onderscheid gemaakt in de aanwezigheid van kennis en de beschikbaarheid (toegankelijkheid) van kennis. Dit onderscheid is afkomstig uit psychologisch onderzoek naar de werking van het menselijk geheugen. De methode die werd 
gebruikt in deze laatste studie (free recall) is veel gebruikt in geheugenexperimenten waarin onderzocht werd in welke mate proefpersonen bestudeerde informatie (o.a. woordenlijsten) konden reproduceren. Analyses van de organisatie in de recall van proefpersonen toonden aan dat er vaak sprake is van een subjectieve organisatie (Shuell, 1969). Onder een subjectieve organisatie wordt een organisatie verstaan die niet rechtstreeks voortvloeit uit de aard van de aangeboden stimuli maar uit de betekenis die het individu zelf geeft aan de waargenomen informatie. Kortom, de organisatie van gereproduceerde informatie wordt bepaald door de reeds aanwezige kennis voor de waarneming van nieuwe informatie. Door niet alleen de free recallmethode toe te passen op de reproductie van de probleeminformatie (=probleemrepresentatie) maar ook op de analyse van de aanwezige kennis werd duidelijk dat er een verband bestaat tussen de organisatie van de gereproduceerde probleeminformatie en de organisatie van de aanwezige kennis.

De subjectieve organisatie van waargenomen informatie is het centrale thema in de schematheoretische inkleuring van modellen van menselijke informatieverwerking. In de schematheorie worden activiteiten als het leren op school, het lezen van teksten, het probleemoplossen in allerlei domeinen en het verrichten van wetenschappelijk onderzoek bestudeerd vanuit een uniforme theorie met een gelijk begrippenkader: voorkennis, toegang, activiteit, organisatie, waarnemen. De overeenkomst tussen deze verschillende activiteiten is 'begrijpen'. De omschrijving door Rumelhart en Ortony (1977) van begrijpen is in dit verband illustratief: "the process of comprehension can be regarded rather like the process a scientist goes through in testing a theory: evidence is sought which either tends to confirm it, or which leads to its rejection". Wilson en Anderson (1986) beschrijven 'begrijpen" als het zoeken naar een samenhangende verklaring van relaties tussen waargenomen objecten of gebeurtenissen in de alledaagse werkelijkheid.

De schematheoretische uitgangspunten spelen ook een belangrijke rol in de ontwikkelingstheorie van expertise. De opzet van deze laatste studie is ontleend aan onderzoek naar de cognitieve ontwikkeling binnen het expertnoviet paradigma. Naast de verwantschap in vraagstelling bestaat er in deze studie eveneens een sterke overeenkomst in de gehanteerde onderzoeksmethode, er is echter ook een verschil. In het expert-noviet paradigma is 'het ontwikkelingsniveau' de criterium-variabele. Personen worden geordend in groepen op basis van hun opleidingsjaren of ervaringsjaren. Afhankelijk van de tijdsduur waarin men in het desbetreffende domein een hoog expertiseniveau bereikt, en daarmee ook afhankelijk van de mate van specialisatie van de kennis in het desbetreffende domein, worden meer of minder niveaus onderscheiden. Vergelijkingen tussen beginners en gevorderden; vergelijkingen tussen beginners, tussenliggende groepen ('intermediates') en 
gevorderden; vergelijkingen tussen beginnende studenten, tweedejaars, vierdejaars, zesdejaars, beginnend beroepsbeoefenaar: alle schaal-indelingen zijn aanwezig. Er is echter wel een overeenkomst: zodra een indeling in groepen is gemaakt worden deze groepen als homogeen beschouwd. Noodzakelijk voor het studie-object, dat immers bestaat uit het zoeken naar verschillen tussen verschillende ontwikkelingsniveaus, maar moeilijk interpreteerbaar voor de onderwijspraktijk. Menig docent kan met een overzicht van studie-resultaten aantonen dat dezelfde groep, die vanuit het perspectief van de ontwikkelingstheorie homogeen is, een sterke mate van differentiatie kent.

In deze studie werd aangetoond dat bepaalde verschillen tussen groepen ook binnen een groep kunnen bestaan. Met betrekking tot proceduralisatie van kennis, organisatie van kennis, opbouw van probleemrepresentatie en activatie van kennis werden in de onderzochte groep derdejaars studenten duidelijke relaties tussen deze variabelen en de kwaliteit van probleemoplossen gevonden.

Deze resultaten ondersteunen een individualistische interpretatie van een ontwikkelingstheorie. Ze doen vermoeden dat de individuele ontwikkeling van kennis binnen een bepaald domein (de fysiotherapie) voor alle mogelijk nader te onderscheiden sub-domeinen (spierklachten, gewrichtsklachten, etc.) niet voor alle studenten in dezelfde fase verkeert. In de cognitieve ontwikkeling wordt eerdere ervaring met problemen sterk benadrukt. Het is niet uitgesloten dat de goede probleemoplossers in de hier onderzochte groep derdejaars studenten meer ervaring hadden (weliswaar binnen een studiecontext) met de casus-onderwerpen in onze steekproef uit de fysiotherapeutische praktijk. Deze draad doortrekkend kunnen onder toename van het aantal metingen binnen een selecte groep proefpersonen, eveneens verschillen binnen een individu verwacht worden. Dit alles roept het beeld op van een per subdomein verschillend ontwikkelingsniveau als gevolg van studie en ervaring. Iemand kan 'goed' zijn in het oplossen van een bepaald probleem als gevolg van een rijk kennisbestand voor dat probleem, en 'slecht' zijn in het oplossen van een ander probleem omdat zijn kennisbestand voor dat probleem zich (nog) niet voldoende heeft ontwikkeld. Op de consequenties van deze 'individualistische' ontwikkelingstheorie voor het onderwijs wordt teruggekomen in het volgende hoofdstuk. 


\section{HOOFDSTUK 6}

\section{De rol van kennis bij het oplossen van fysiotherapeuti- sche problemen: implicaties voor het onderwijs}

\section{Inleiding}

In het slothoofdstuk van dit proefschrift worden enkele implicaties voor onderwijs geformuleerd die aansluiten bij de resultaten van de vier studies die zijn beschreven in de voorgaande hoofdstukken. Daartoe worden in hei eerste gedeelte van dit hoofdstuk de resultaten van de vier studies nog eens samengevat en bediscussieerd binnen een theoretisch kader dat is gebaseerd op onderzoek naar de werking van het menselijk geheugen. Immers, de essentie van de kennisafhankelijkheid van probleemoplossen is de raadpleging van het geheugen tijdens het denkproces. Geheugenonderzoek wordt echter meestal uitgevoerd in een laboratoriumsituatie, en dat maakt het niet eenvoudig de onderzoeksresultaten te vertalen naar de onderwijspraktijk. Toegepast onderzoek ter ondersteuning van de onderwijspraktijk, zoals in dit proefschrift gepresenteerd, is daarom een noodzakelijke aanvulling op laboratoriumstudies.

In het tweede gedeelte van dit hoofdstuk worden enkele suggesties voor de inrichting van het onderwijsleerproces besproken die van toepassing zijn bij de resultaten van cognitief-psychologisch onderzoek binnen een onderwijscontext. Kernelement in deze bespreking is hoe onderwijsmaatregelen de vorming van de probleemrepresentatie tijdens het probleemoplossen en de invloed die de kennis hierop heeft, kunnen bevorderen. 


\section{Probleemoplosvaardigheid en individuele ontwikkeling van kennis: discussie over de resultaten van de vier studies}

In Hoofdstuk 1 werd ter inleiding op vier studies naar de kennisafhankelijkheid van probleemoplossen een globale schets gegeven van de cognitieve aspecten van het diagnostisch proces. De vorming van een initiele probleemrepresentatie in de beginfase die in het verdere verloop van dit proces wordt gecompleteerd, uitmondend in een diagnostische beslissing, werd als hoofdkenmerk van het diagnostisch proces aangewezen. Startpunt voor het in dit proefschrift beschreven onderzoek vormde de constatering dat de probleemoplosaanpak of -methodiek niet fundamenteel veranderde bij toenemende diagnostische expertise (Neufeld et al., 1981). Het gebrek aan consistentie in de toepassing van probleemoplosmethoden onder ervaren artsen (Elstein et all, 1978) vormde een andere aanwijzing dat de probleemoplosvaardigheid eerder afhankelijk zou kunnen zijn van de beheersing van (voor het probleem specifieke) kennis dan van algemene oplosstrategieën. De rol die kennis speelt in het oplossen van problemen werd in de vier voorgaande studies onderzocht met behulp van instrumenten die enerzijds verondersteld werden de beheersing van probleemrelevante kennis te meten en anderzijds probleemoplosvaardigheid. Steeds werd zorgvuldig geprobeerd de verschillende instrumenten inhoudelijk op elkaar af te stemmen, vanuit de veronderstelling dat alleen op deze wijze een direct verband tussen kennis en probleemoplossen kan worden onderzocht. Een rechtstreekse verklaring van de vaardigheid in het oplossen van problemen uit de beheersing van specifieke, probleemrelevante, kennis kon echter in drie van de vier studies niet worden aangetoond.

Zo zagen wij dat in de eerste studie geen verband kon worden gevonden tussen kennisniveau en probleemoplosvaardigheid. De hypothese dat scores van kennistoetsen en probleemoplostoetsen met inhoudelijke verwantschap sterker correleren dan scores van probleemoplostoetsen onderling moest worden verworpen. Zowel tussen scores van kennistoets en probleemoplostoets als tussen de scores van probleemoplostoetsen onderling bleek een zwak verband te bestaan. In de eerste studie werd het verband tussen kennis en probleemoplossen echter onderzocht op een betrekkelijk globaal niveau. Daarom werd in de tweede studie opnieuw een poging ondernomen, waarbij gepoogd werd de specificiteit van de meting te verhogen door de problemen in omvang en complexiteit te beperken. Op deze wijze werd het verband tussen kennisbeheersing en probleemoplosvaardigheid dus onderzocht door vergelijking van de prestaties van proefpersonen 
op korte problemen met de antwoorden op slechts enkele kennis-items. Analyses waren erop gericht na te gaan hoe groot de kans op een juiste probleemoplossing was indien relevante voorkennis aanwezig was. Het resultaat van deze analyses toonde aan dat de wijze waarop werd gezocht naar het verband tussen kennis en probleemoplossen, namelijk als verband tussen kennisbeheersing en probleemoplosvaardigheid zoals gemeten met verschillende instrumenten, een te sterke vereenvoudiging van de werkelijkheid moest zijn. Immers, aan deze analyse-methode ligt impliciet de opvatting ten grondslag dat kennis waarover een proefpersoon beschikt, ook ten allen tijde toegankelijk is. Dit nu lijkt niet het geval. Personen kunnen kennis hebben (zoals blijkt uit het goed beantwoorden van relevante kennisitems) die ze niet gebruiken wanneer deze toepasbaar is (zoals blijkt uit fouten bij het oplossen van problemen waarbij dezelfde kennis nodig is).

Het zwakke verband tussen kennis en probleemoplossen zou echter wellicht het gevolg kunnen zijn van een verschil in de aard van de taken die een proefpersoon moet uitvoeren. Zo zou men kunnen veronderstellen dat de beantwoording van een item uit een kennistoets simpelweg een eenvoudiger opgave is dan de oplossing van een probleem, ook al bestaat er een inhoudelijke overeenkomst tussen het kennisitem en het probleem. In fundamenteel onderzoek naar geheugenprocessen, dat ter verklaring van onze resultaten relevant zou kunnen zijn, wordt een onderscheid gemaakt tussen herkennen (recognition) en herinneren (recall). In onderzoek naar deze geheugenprocessen leren proefpersonen gewoonlijk woorden of korte zinnen uit hun hoofd. Vervolgens wordt hen gevraagd uit een soortgelijke lijst woorden als in de leerfase gepresenteerd, aan te geven of deze woorden wel of niet deel uitmaakten van de geleerde lijst. Met andere woorden: deze taak doet een beroep op herkenning. De proefpersoon kan ook worden verzocht de volledige lijst van geleerde woorden te reproduceren. Dan is er sprake van herinnering. De herkenningstaak blijkt meestal beter te worden uitgevoerd dan de herinneringstaak (Reynolds en Flagg, 1977). Hier ligt wellicht een verklaring voor de resultaten van de eerste twee studies van dit proefschrift. Immers, daarin werden kennisitems die een beroep deden op herkenning door de proefpersoon goed beantwoord, terwijl dezelfde kennis niet werd herinnerd bij de oplossing van het verwant probleem. De kennistoets zou dus kunnen worden opgevat als een herkenningstaak, terwijl het oplossen van een probleem als een herinneringstaak kan worden beschouw $\mathrm{d}^{i}$. Het onderscheid tussen herkennen en herinneren is een belangrijk

'Deze vergelijking, van de in de voorgaande studies gebruikte methoden met de in laboratoriumonderzoek gebruikte methoden, gaat overigens niet geheel op. Met name de karakterisering van een kennistoets als herkenningstaak is bekritiseerbaar omdat de items 
kenmerk van wat men in geheugentheoretisch onderzoek de "tweeprocestheorie" noemt (Kintsch, 1974). Deze tweeproces-theorie beschrijft herkennen als het nemen van beslissingen (ja/nee) of het gepresenteerde item in de testfase overeenkomt met het geleerde item uit de leerfase. Herinneren zou daarentegen een ingewikkelder proces zijn. Ook bij herinneren zou er sprake kunnen zijn van een zelfde beslissingsproces als bij herkennen, maar dat zou dan voorafgegaan worden door een zoekproces. Dus, eerst wordt informatie gezocht, vervolgens wordt beslist of de gevonden informatie gelijk is aan de gezochte. Deze tweeproces-theorie is gebaseerd op feitelijke verschillen in effect van twee condities op de prestaties in herkenning en herinnering. In de eerste plaats werd gevonden dat intentioneel leren een positief effect heeft op herinnering, echter niet op herkenning. In de tweede plaats heeft de structuur van het leermateriaal eveneens een positief effect op herinnering, en niet op herkenning ${ }^{2}$ (Sowa, 1983). Als de herinnering wel kan worden beinvloed, maar niet de herkenning, is er dus sprake van verschillende geheugentaken. Maar is er bij de verschillende taken ook sprake van verschillende geheugenprocessen? De veronderstelling dat in de uitvoering van een herkenningstaak geen zoekproces zou plaatsvinden is niet empirisch bewezen (Shiffrin, 1970). De doorgaans betere prestaties op herkenningstaken is derhalve niet direct verklaarbaar uit een principieel verschil in onderliggende geheugenprocessen, hoogstens uit een meer oppervlakkig verschil in de presentatie van de test. Een herkenningstaak kan meer "retrieval cues" bevatten (Wickelgren, 1979) en als zodanig eenvoudiger zijn bij een zoekproces. Samenvattend: Voor de resultaten van de eerste twee studies in dit proefschrift biedt het veronderstelde onderscheid in complexiteit tussen herkennen en herinneren geen voldoende verklaring. Herkenningstaken kunnen daarentegen wel, tengevolge van de presentatievorm, aanwijzingen bevatten die ontbreken in herinneringstaken. Dit zou kunnen verklaren waarom kennisitems vaker correct werden beantwoord dan de bijbehorende problemen.

In een experiment, beschreven in Hoofdstuk 4, dat was gericht op de activatie van kennis door middel van structurering van relevante concepten werd opnieuw het verband onderzocht tussen de meting van kennis en probleemoplosvaardigheid. De casus waarmee de controle- en experimentele groep met elkaar werden vergeleken bevatte een ordenend principe (acute

van een kennistoets meestal niet in de letterlijke bewoording worden gepresenteerd zoals ze zijn geleerd uit een tekstboek, maar als een parafrase daarvan (Langerak, 1979).

2 Woorden kunnen herinnerd worden door associaties omdat deze in de leerfase met elkaar zijn verbonden door categorisatie bijvoorbeeld. 
verandering in een chronisch klachtenbeeld van een patiènt) dat in meerdere casus toepasbaar is. Door middel van analogieèn en schematisering werden de proefpersonen gestimuleerd tot (her)ontdekking van dit principe. De experimentele groep werd expliciet gewezen op de mogelijkheid dit principe te gebruiken in de criteriumcasus. Verondersteld werd dat deze onderwijskundige manipulatie relevante kennis zou activeren die studenten kon helpen bij het oplossen van een nieuw probleem. Deze experimentele manipulatie had echter niet het beoogde effect. Er werden geen verschillen in prestatie gevonden tussen de groep die geleerd had een algemeen bruikbaar principe te extraheren en de groep die dat niet geleerd had. Dat betekende onder andere dat de kans op een juiste probleemoplossing, onder conditie van correcte beantwoording van de kennisitems, niet significant hoger was voor de experimentele groep. De conclusie die hieruit kan worden getrokken is de volgende: Een algemeen principe in de vorm van een structuur tussen symptomen die kan worden waargenomen in de beginfase van het diagnostisch proces is blijkbaar een te zwakke "retrieval cue" om kennis, nodig om een casus op te lossen, uit het geheugen op te halen.

In de laatste studie van dit proefschrift werd ten aanzien van de meting van kennis een andere richting ingeslagen. Waren de eerste drie studies gericht op een meting van de mate waarin kennis beheerst werd - een kwantitatieve benadering dus in de context van herkenningstaken - de laatste studie richtte zich vooral op de kwalitatieve aspecten van probleemrelevante kennis. In de vierde studie werden eerst de probleemrepresentaties van negen proefpersonen bij vier probleemtaken geanalyseerd. Nagegaan werd in hoeverre er relaties bestonden tussen kenmerken van die probleemrepresentaties en de daarbij behorende goede of foute oplossingen. Immers, verondersteld werd dat de samenhang tussen kennis en probleemoplossen tot uitdrukking zou moeten komen in de aard van de resulterende representatie. Er werden duidelijke verschillen in probleemrepresentaties gevonden bij goede en foute oplossingen. Bij een goede oplossing bevatte de probleemrepresentatie meer diagnostisch relevante informatie. De omvang van de probleemrepresentatie verschilde echter niet bij goede en foute oplossingen. Zoals in Hoofdstuk 1 ter inleiding op de afzonderlijke studies reeds werd beschreven kan het missen van de juiste diagnose worden geïnterpreteerd als de afwezigheid van kennis of het achterwege blijven van de activatie van die kennis. Naast de verschillende probleemrepresentaties werd daarom kennis, waarvan verondersteld werd dat ze geactiveerd was tijdens het oplossen van de problemen, onderworpen aan een contrastanalyse ten aanzien van een aantal kwalitatieve kenmerken. De gegevens waarop deze analyse werd uitgevoerd werden verkregen via een free recall-opdracht om alle kennis die men zich met betrekking tot de te diagnostiseren aandoeningen wist 
te herinneren, te reproduceren. De kwalitatieve kenmerken waarop deze kennisprotocollen werden onderzocht waten: de relevantie van de gereproduceerde concepten in het licht van de diagnose, de conceptuele structuur van de gereproduceerde kennis en de mate van proceduralisatie van de gereproduceerde kennis. De kennisprotocollen behorende bij goede diagnoses bleken vergelijkenderwijs in sterkere mate deze kenmerken te bezitten. Goede diagnoses gingen gepaard met meer geintegreerde kennis.

De analysemethoden die in de vierde studie werden toegepast werden ontleend an studies binnen het zogenaamde expert-nowiet paradigma. Dat paradigma wordt gebruikt bij onderzoek naar de ontwikkeling van kennis gedurende een lang leerproces, over jaren. Vanwege de lange duur van zo'n leerproces worden groepen proefpersonen onderzocht die heterogeen zijn met betrekking tot hun niveau van ontwikkeling. In de vierde studie werd echter een homogene groep onderzocht. Ter herinnering, de proefpersonen waren allen afkomstig uit het derde studiejaar van een vierjarige opleiding. Uit het feit dat, net als in veel onderzoek naar verschillen tussen experts en novieten, verbanden werden gevonden tussen kwalitatieve kenmerken van kennis en probleemoplosvaardigheid, kan worden afgeleid dat de kennis van de verschillende proefpersonen, maar ook binnen de proefpersonen over de verschillende onderwerpen, in een verschillende ontwikkelingsfase verkeerde. Dit is de hoofdconclusie uit de resultaten van de vierde studie: de kennisafhankelijkheid van probleemoplossen wordt niet alleen bepaald door de mate van kennisbeheersing maar ook door de mate waarin kennis zich heeft ontwikkeld. Voor een juist begrip van deze conclusie zal, voorafgaande aan een meer uitwoerige bespreking van de bevindingen waarop deze conclusie is gebaseerd, de ontwikkeling van kennis worden geschetst.

Boshuizen (1989) veronderstelt dat een medisch expert over een kennisbestand beschikt dat drie niveaus omvat: 1 . kennis van de medische basisvakken, 2. kennis in de vorm van ziektescripts en 3. episodische kennis (herinneringen aan concrete patiëntcontacten). Het opvallende aan deze opvatting is dat het enerzijds een model is met een ordening naar verschillende soorten kennis - waarvan met name de derde kennislaag als de meest effectieve kennis voor het diagnostiseren wordt aangeduid (Schmidt, Boshuizen en Norman, 1990) - maar dat hij anderzijds ook de sporen draagt van de veranderingen die kennis ondergaat gedurende de ontwikkeling van expertise. In de beginfase van het leerproces verwerft de student kennis over ziekten of aandoeningen waarbij oorzaken en gevolgen worden verklaard in termen van onderliggende pathofysiologische processen. Door herhaalde toepassing van deze verworven kennis in het oplossen van patiëntproblemen wordt de declaratieve kennis gecompileerd tot kennis van een hoger en vereenvoudigd niveau. Min of meer gelijk met deze compilatie 
vindt er ook een herordening van kennis plaats, van causaal georiënteerde conceptuele netwerken tot scripts met een lijststructuur. De toepassing van deze scripts voegt ook een element toe. Immers, naast de oorzaken en gevolgen verwerft de student aanvullend kennis over condities waaronder deze oorzaken en gevolgen zich kunnen manifesteren. Het sluitstuk van deze ontwikkeling is de vorming van episodische kennis als gevolg van herhaalde toepassing van ziektescripts (Schmidt en Norman, 1989; Norman et al., 1989; Schmidt en Norman, 1990).

Het niveau waarop de probleemoplosser zijn geheugen aanspreekt tijdens het probleemoplossingsproces hangt samen met de mate waarin het probleem in kwestie de probleemoplosser "bekend" voorkomt en routinematig kan worden opgelost. Kennis uit het episodisch geheugen is snel toegankelijk en vaak ook voldoende voor de oplossing van het probleem in kwestie. Anders gezegd, "cues" die een nieuwe patiënt afgeeft, en de samenhang hiertussen, worden herkend waarbij een nagenoeg complete probleemrepresentatie als één kennisgeheel wordt geactiveerd. Diagnostiseren op dit (kennis)niveau is in feite herkennen van een probleemsituatie zonder dat er sprake is van een bewust zoekproces in het geheugen van de probleemoplosser. Slaagt de probleemoplosser hier niet in, dus wordt de situatie niet herkend en is het probleem derhalve minder eenvoudig, dan is er sprake van een zoekproces. In de eerste plaats zal dit gebeuren door een raadpleging van het geheugen ten aanzien van kennis over ziekten of aandoeningen in een bepaalde categorie (of met elkaar verwante categorieën) die dan wel zo georganiseerd (scripts) moet zijn dat de "retrieval cues" (bijvoorbeeld symptomen) waarmee die kennis wordt geactiveerd aansluiten bij de "cues" in de probleemsituatie. Kan ook op deze wijze geen passende probleemrepresentatie worden gevormd, dan is er sprake van een "moeilijk" probleem en wordt de kennis op het basisniveau aangesproken. Er is dan sprake van redeneren waarin de twee eerder genoemde geheugenprocessen, zoeken èn beslissen, elkaar afwisselen.

In de vierde studie werd de proefpersonen slechts een korte leestijd gegeven om kennis te nemen van alle probleeminformatie. Door de beperking van de tijd werd dus voorkomen dat men ging redeneren. Ook met redeneren kan men weliswaar tot een goede oplossing komen maar, gelet op de zojuist geschetste theorie over ontwikkeling en toepassing van kennis, wordt in dat geval de kennis van een lager niveau aangesproken. De veronderstelling dat voor succesvol probleemoplossen kennis benodigd is van een hoger ontwikkelingsniveau werd in diverse hypothesen getoetst. Daartoe werd de kennis over de (te diagnostiseren) aandoening van proefpersonen die de juiste diagnose formuleerden in een contrastanalyse vergeleken met de kennis van proefpersonen die niet de juiste diagnose formuleerden. De 
volgende verschillen werden daarbij gevonden. $\mathrm{Bij}$ een goede probleemoplossing werd een rijker kennisbestand (meer concepten) geactiveerd. Dit is een indicatie voor een betere kennisorganisatie. De organisatie van de individuele kennis werd vervolgens vergeleken met de conceptuele structuur van een ideaaltypisch model van de aandoening uit een handboek. Uit deze vergelljking bleek dat de kennisprotocollen behorende bij de goede diagnoses meer relevante concepten bevatte. Bovendien was er sprake van meer identieke relaties tussen de concepten in vergelijking met het ideaaltypisch model. Tenslotte werd getoetst of de kennis bij de goede diagnoses in sterkere mate was ontwikkeld van declaratieve kennis naar procedurele kennis. Ook deze hypothese werd bevestigd. Samenvattend is de bijdrage van deze bevindingen aan de eerder geschetste theorie over stadia in de ontwikkeling van expertise de volgende: De beschreven ontwikkelingsprocessen op basis van expert-noviet vergelijkingen lijken in de eerste plaats sterk individueel bepaald omdat ook binnen een groep studenten, die globaal gesproken op een gelijk ontwikkelingsniveau verkeert, verschillen konden worden gevonden in de mate van ontwikkeling van kennis. Bovendien zijn deze ontwikkelingsprocessen blijkbaar in hoge mate subdomeingebonden aangezien in de laatste studie een verband werd gevonden tussen kennis en probleemoplossing: een student kan binnen het domein fysiotherapie kennis toepassen uit verschillende subdomeinen (bijvoorbeeld rugklachten, schouderklachten, etc.) die onderling kunnen verschillen in hun mate van ontwikkeling. Voor de inrichting van het onderwijs betekent dit dat men rekening moet houden met de individuele ontwikkeling van kennis en dat de onderwijsmethode moet aansluiten bij de fase van ontwikkeling waarin deze kennis verkeert. In de volgende paragraaf zal dit gegeven terugkomen in de bespreking van de implicaties voor onderwijs.

\section{Implicaties voor onderwijs}

Het blijkt niet altijd eenvoudig te zijn om cognitief-psychologische onderzoeksresultaten rechtstreeks toe te passen in de alledaagse onderwijspraktijk (Cazden, 1976; Sternberg, 1986; Dijkstra, 1986). Dit komt onder andere door het feit dat in de vormgeving van het onderwijs ook andere elementen een rol spelen dan alleen resultaten van wetenschappelijk onderzoek, zoals: deskundigheid van docenten, financiële ruimte, beschikbaarheid van leermiddelen, etc. Terwille van de acceptatie van de resultaten is het derhalve niet geboden de resultaten van onderzoek, dat zich noodzakelijkerwijs voltrekt binnen een beperkt blikveld, te vertalen in zeer concrete onderwijssce- 
nario"s. Daarom zal in deze afsluitende paragraaf de systematiek worden benadrukt waarmee cognitief-psychologische onderzoeksresultaten kunnen worden toegepast en enkele principes die ten grondslag kunnen liggen aan de inrichting van het onderwijsleerproces worden besproken vanuit het kader van de hier gevonden onderzoeksresultaten.

Indien de doelstelling van het onderwijs is de student (beter) te leren diagnostiseren zal de inhoud en vormgeving van het onderwijs, gezien vanuit de invalshoek van de studies in dit proefschrift, zowel de probleemrepresentatie als de daarmee verbonden kennis moeten accentueren. Ter inleiding op enkele afsluitende opmerkingen over de inrichting van het onderwijsleerproces die aansluiten bij de voorgaande studies worden twee experimenten besproken die deze beide aspecten, de vorming van een probleemrepresentatie en de ontwikkeling van kennis, verschillend benadrukken.

Larkin (1983) is van mening dat de probleemoplosvaardigheid van studenten kan worden verbeterd door hen te trainen in het schematiseren van problemen. Vanuit deze opvatting bepleit zij het opnemen van conceptuele schema's in teksten van studieboeken. In het natururkundig domein werd dit experimenteel onderzocht door een groep studenten eerst te instrueren over een aantal principes/wetten van gesloten elektrische stroomkringen. De helft van deze groep kreeg een extra training in het visualiseren van deze stroomkringen op een wijze waarop ook experts dit doen. De controlegroep kreeg aanvullende training in het rekenkundig toepassen van de geleerde principes in vergelijkingen. In de testfase moesten beide groepen een serie problemen oplossen waarbij de experimentele groep significant beter presteerde. Dit betekent dus dat de probleemoplosvaardigheid kan worden verbeterd indien studenten leren het probleem te representeren op een wijze die ook experts in de praktijk brengen. Training in het representeren van probleemsituaties is een directe benadering van het leren probleemoplossen in tegenstelling tot een meer indirecte benadering waarin wordt getracht tijdens de fase van kennisverwerving de aangeboden kennis zodanig te structureren dat deze faciliterend is voor de vorming van een probleemrepresentatie.

Beck en Bergman (1986) onderzochten in het medisch onderwijs het effect van structurering van leerstof op de diagnostiek van congenitale hartziekten. Alle proefpersonen moesten eerst een inleidende tekst bestuderen over het cardiovasculair systeem. De experimentele groep kreeg vervolgens aanvullende informatie aangeboden over een aantal afzonderlijke hartziekten waarin de overeenkomsten en verschillen in (groepen) symptomen tussen de afzonderlijke ziekten sterk werd benadrukt. De controle-groep kreeg dezelfde informatie over de afzonderlijke hartziekten aangeboden waarin werd volstaan met de bespreking van de pathofysiologie van proto- 
typische voorbeelden. Er werden geen relaties gelegd tussen de afzonderlijke ziekten. In de testfase kregen beide groepen in de vorm van een computersimulatie een aantal casus gepresenteerd van verschillende moeilijkheidsgraad. Vergelijking van beide groepen liet zien dat de experimentele groep meer diagnostisch relevante informatie verzamelde, eerder de correcte diagnose formuleerde en de moeilijkste (atypische) casus vaker met de juiste diagnose afsloot. Beck en Bergman veronderstellen dat slechts kleine accentverschillen in de presentatie van de leerstof kunnen leiden tot grote verschillen in het diagnostisch proces dat op deze kennis is gebaseerd.

In beide onderzoeken wordt de keuze voor de concrete inrichting van het onderwijsleerproces beargumenteerd op basis van een analyse van de veronderstelde ontwikkeling van noviet tot expert in de desbetreffende vakgebieden. Larkin constateerde in het natuurkundig domein dat novieten een meer naieve probleemrepresentatie hanteren dan experts en trekt daaruit de conclusie dat het voor onderwijs in natuurkundig probleemoplossen noodzakelijk is novieten (direct) te trainen in de representatie van de probleeminformatie, overeenkomstig de aanpak van experts. Beck en Bergman accentueren echter meer de voorwaardelijke (indirecte) kant van het probleemoplossen. Hun pleidooi voor het structureren van de leerstof over ziekten, met expliciete aandacht voor overeenkomsten en verschillen in ziektebeelden, wordit ontleend aan de constatering dat experts hun kennis op soortgelijke wijze georganiseerd hebben. Dit voorbeeld laat zien dat de onderwijskundige richtlijnen, die in beide gevallen zijn gebaseerd op een analyse van de verschillen in expertise, kunnen verschillen in de concrete uitwerking. Er is dan ook een behoefte aan een zekere systematiek om de veelheid van onderzoeksresultaten vruchtbaar te maken voor de onderwijspraktijk.

Deze systematiek kan worden gevonden in wat Glaser (1976 a, 1976 b) een "linking science" noemt: de onderwijspsychologie als schakel tussen de wetenschappelijke kennis over het leren (inclusief cognitie en ontwikkeling) en de onderwijstoepassing hiervan. De volgende vier taakgebieden worden daarbij onderscheiden: de analyse van competentie (eindniveau van leerproces), de analyse van het beginniveau in het leerproces, de analyse van condities die de verwerving van competentie beinvloeden en de analyse van effecten van implementatie in het onderwijs ${ }^{3}$.

"Opvallend is de gelijkenis van deze taakgebieden met de componenten van het Didactisch Analyse-model (De Corte et al., 1973) dat een brede ingang heeft gevonden in de praktijk van het basisonderwijs. Echter, vanwege het formele karakter van het model is het niet gebonden aan niveau of vakgebied en kan dan ook bruikbaar zijn voor het hoger onderwijs. Gaat het hier om een model dat bruikbaar is voor onderwijsvoorbereiding, -uitwoering en -evaluatie, eveneens is er sprake van modelvorming die beperkt blijft tot de constructie van onderwijs (Andrews \& Goodson, 1986). 
In de toepassing van de inzichten met betrekking tot de kennisafhankelijkheid van probleemoplossen zal dus, conform de volgorde van de vier taakgebieden, eerst een analyse moeten worden uitgevoerd langs welke weg kennis zich ontwikkelt in de groei van expertise. Uit de vergelijkingen van novieten en experts enerzijds, maar ook vanuit de methode die is gebruikt in de vierde studie waarin een verband werd gezocht tussen kennis en probleemoplossing, kan inzicht worden verkregen in de veranderingen die kennis ondergaat tijdens het leerproces. Op basis van de in de vorige paragraaf besproken theorie over de ontwikkeling van kennis kan het volgende gesteld worden: vanuit de primaire verwerving in de basisvakken verandert de kennis onder invloed van ervaring met betrekking tot niveau en representatie. Daarbij wordt de kennis modelmatig georganiseerd rond ziekten en aandoeningen zoals deze in de praktijk worden gediagnostiseerd.

Voor de analyse van de onderwijscondities die deze verwerving van competentie kunnen beïnloeden is een leertheorie nodig waarin verschillende leervormen worden onderscheiden in aansluiting op de onderscheiden ontwikkelingsstadia. Het moet ook een theorie over het leren zijn die bruikbaar is voor omvangrijke en complexe leerstof die in een 》angdurig leerproces wordt verworven. De gebruikelijke leertheorieën houden zich echter bezig met relatief compacte leerstofeenheden in een kortdurend leerproces. Het benodigde tegenvoorbeeld kan gevonden worden in een model van leren waarin drie leervormen worden onderscheiden die, elk afzonderlijk, een verschillende bijdrage leveren aan de kennisstructuur van de student (Rumelhart \& Norman, 1978; Norman, 1978). Bovendien wordt verondersteld dat verschillende onderwijsvormen noodzakelijk zijn om het leerproces te laten plaats vinden en ook afzonderlijke toetsprocedures om te kunnen vaststellen of het gewenste leerproces heeft plaatsgevonden. Deze leervormen zijn: kennistoename, kennisherstructurering en kennisaanpassing. Onder kennistoename (accretion) wordt het basisleerproces verstaan waarin reeds aanwezige kennisstructuren worden aangevuld of geheel nieuwe structuren worden gevormd. Kennisherstructurering vindt plats indien structuren worden samengevoegd (generalisatie, abstractie) of in zijn geheel worden vervangen door nieuwe (vaak beter toegankelijke) structuren (bijvoorbeeld schema-inductie). De geherstructureerde kennis bevordert het inzicht in de leerstof en kan, vanwege de nieuwe interpretatie van "oude" kennis, een basis vormen voor verdere kennisgroei. In de derde leervorm "kennisaanpassing" (tuning) is er geen sprake meer van toevoeging van nieuwe concepten of conceptuele structuren, maar van geringe, weliswaar wezenlijke, veranderingen in de bestaande kennisstructuren. Daarbij wordt kennis in overeenstemming gebracht met de eisen die kunnen worden gesteld aan een optimaal gebruik van deze kennis in de praktijk (routines, vereenvoudiging, 
automatisering). Deze verschillende leerprocessen kunnen zich ook tegelijkertijd voltrekken. Een student kan op een bepaald moment binnen een subdomein nieuwe kennis verwerven, in een tweede subdomein tegelijkertijd reeds aanwezige kennis herstructureren en tot een nieuw inzicht komen, en in een derde subdomein kennis leren afstemmen op het gebruik in de praktijk. In hypothetische tijdcurves laat Norman (1978) zien dat kennistoename en kennisherstructurering wisselend kunnen domineren in het leerproces en op den duur beide sterk afnemen (bijvoorbeeld in de eindfase van de opleiding) waarna de derde leervorm, kennisaanpassing, gaat domineren. Samengevat: In een langdurig leerproces is er sprake van verschillende leervormen waarbij het ontwikkelingsniveau ook kan verschillen per onderdeel van een compleet leerstofdomein. In de beginfase zal de kennisverwerving domineren, in de tussenfase zal kennisverwerving en kennisherstructurering wisselend domineren om aan het einde te worden afgesloten met afstemming van de verworven kennis op de praktijk.

In de inrichting van het onderwijs, op het globale niveau van het curricullum, zijn de genoemde leervormen ook herkenbaar. Gebruikelijk is het de student eerst in hoofdzaak theoretisch in te leiden om gaandeweg het accent te leggen op de toepassing van deze theoretische kennis in de praktijk. De consequenties voor de onderwijspraktijk van theorieën over de ontwikkeling van kennis zijn echter specifieker te formuleren. Frederiksen (1984) (maar ook anderen: Montague, 1986; Bransford, Sherwood, Vye \& Rieser, 1986; Elstein, Sprafka \& Bordage, 1979) formuleerde in een overzichtspublicatie een aantal implicaties van de cognitieve theorie voor onderwijs. In het overzicht is niet zo zeer sprake van aanwijzingen die elkaar uitsluiten maar die elkaar aanvullen, waarbij de accentuering kan verschillen in relatie tot de omvang en complexiteit van het domein. Dit overzicht van Frederiksen wordt hier overgenomen waarbij deze richtlijnen voor onderwijs worden belicht vanuit de resultaten van de studies in dit proefschrift.

Onderwijs in cognitieve processen. Deze opvatting is in principe de meest directe toepassing van het cognitief-psychologisch onderzoek in de onderwijspraktijk. Analyse van competent gedrag is vanuit deze opvatting de basis voor een rationeel verantwoorde constructie van het onderwijs (zie hiervoor onder andere Braune \& Forshay, 1983 en Stephens, Bhaskar \& Dillard, 1981). Een hypothetisch voorbeeld ter illustratie. Indien, zoals gebleken is in de analyse van het diagnostisch proces van ervaren beroepsbeoefenaren, de formulering van de hypothesen in de beginfase van het consult een cruciale factor is zou men kunnen overwegen specifieke trainingen te ontwerpen in de differentiaaldiagnostiek. Het risico dat men daarbij echter loopt is dat de rol die kennis speelt in het hypothetiseren als mentale activiteit wordt onderschat. Niet het hypothetiseren, als een op 
zichzelf staande activiteit, leidt tot de goede diagnose maar de formulering van de juiste hypothese. Zoals uit de resultaten vain de voorgaande studies is gebleken spelen kwalitatieve kenmerken van kennis hierin een sterke rol. Derhalve zal directe instructie van cognitieve processen in samenhang moeten worden beschouwd met de kennisbasis voor deze cognitieve processen. Voor de evaluatie van het leerproces kan deze directe benadering van de cognitieve processen echter inspirerend werken. Toetsing van expertise zou gericht kunnen zijn op de vastlegging van de snelheid waarmee tot een juiste hypothese wordt gekomen, al of niet met manipulatie van de "cues" die worden gegeven in de probleeminformatie. Computerondersteunde toetsing van studenten kan daarin behulpzaam zijn (Van der Vleuten, 1990).

Onderwijs in de ontwikkeling van probleemstructuur. Vanuit deze opvatting wordt een accent gelegd op de probleemanalyse als leeractiviteit. In principe gaat het hier om het aanleren van probleemoplosmethoden of heuristieken die algemeen van aard zijn en niet kennisspecifiek. Aan deze opvatting ligt de verwachting ten grondslag dat er sprake kan zijn van transfer naar nieuwe problemen. Uit de resultaten van de derde studie waarin werd getracht, via een analogie, de proefpersonen tot een goede probleemoplossing te leiden kan worden afgeleid dat deze transfer niet overschat mag worden. Een andere betekenis krijgt de probleemanalyse wel wanneer dit niet het doel is van onderwijs maar middel tot. In probleemgestuurd onderwijs bijvoorbeeld zal een student de probleemanalyse gebruiken om kennishiaten vast te stellen en leerdoelen te formuleren voor verdere kennisverwerving. De probleemanalyse biedt dan de context waarbinnen het leerproces plaats vindt. Bijzondere aandacht moet daarbij dan wel worden geschonken aan de integratie van de leerresultaten met de resultaten van de voorgaande probleemanalyse.

Onderwijs in patroonherkenning. Deze opvatting is enigszins verwant aan de zojuist besproken probleemanalyse, in die zin dat de probleemstructuur centraal staat. De nadruk ligt hier echter niet op de analyse als leeractiviteit teneinde een probleemstructuur te "ontdekken", maar op de herkenning van een probleemstructuur als geheel. Gerichte training in patroonherkenning behoort zeker tot de mogelijkheden maar zal toch eerder moeten worden gesitueerd in de eindfase van het leerproces. Vanuit de hierboven geschetste theorie over de ontwikkeling van expertise kan worden afgeleid dat als voorwaarde voor patroonherkenning geldt dat een ruime hoeveelheid kennis in het domein is verworven en is geherstructureerd. In die zin is patroonherkenning een aspect van de leervorm "kennisaanpassing".

Onderwijs in de ontwikkeling van kennisstructuren. Gelet op het belang van de organisatie van kennis voor de probleemoplosvaardigheid zal er zeker expliciet aandacht moeten worden besteed aan de structurering van de 
kennis tijdens het leerproces. De vraag is echter in welke mate daarvoor expliciet aparte onderwijsprocedures moeten worden ontwikkeld, of dat de alandacht voor kennisstructurering geintegreerd is in andere onderwijsactiviteiten. Een directe weg is, bij de presentatie van bijvoorbeeld studieteksten, de gewenste structuur te beschrijven en deze aanvullend te visualiseren in schema"s of modellen. Gelet op de hierboven geschetste theorie van de ontwikkeling van expertise zal het ordeningsprincipe in deze directe vorm van kennisstructurering een categorisatie moeten zijn van de in de praktijk te diagnostiseren ziekten of aandoeningen. Daarbij moet vooral aandacht worden geschonken aan de geordende beschrijving van symptomen zoals deze in de praktijk herkenbaar zijn. Immers, dit zijn de "retrieval cues" in de toepassing van kennis tijdens het diagnostiseren. Ondanks de positieve effecten van het eerder beschreven onderzoek van Beck en Bergman (1986), waarin het effect van leerstofstructurering op de toepassing van kennis werd onderzocht, mag ook deze benadering niet worden overschat. Directe presentatie van de kennisstructuur blijft statische kennis voor de student en de vraag blijft of de aangeboden kennisrepresentatie aansluit op de reeds bij de student aanwezige kennisstructuur. Kennis wordt dynamischer als de student zelf de aangeboden kennis moet schematiseren waarbij de geexpliciteerde kennisstructuur van de docent als correctieve feedback kan functioneren. Dit vraagt van de docent, als expert in het vakgebied, tevens een didactisch inzicht in de geleidelijke ontwikkeling van kennisstructuren. Een hulpmiddel in dit verband kunnen specifiek voor kennis-schematisering ontwikkelde computerprogramma's zijn waarmee studenten ervaring kunnen opdoen in de representatie van hun kennis in een bepald domein (Kommers 1988 a, 1988 b; De Grave, 1990).

Geleide praktijk. Onder deze onderwijsmethode wordt het ervaringsleren (learning by doing) gerekend. Geleide praktijk gaat verder dan het eenvoudigweg laten opdoen van ervaringen. Het is een leerproces waarin de student op basis van ervaringen, naast de praktijkfeedback zelf, aanvullend feedback krijgt van de docent. Ervaringsleren kan de volgende leereffecten hebben: eerder verworven kennis wordt geassocieerd met gebruikssituaties, in de toepassing van kennis wordt deze kennis geherstructureerd waarbij in het algemeen de toegankelijkheid van deze kennis wordt bevorderd (bijvoorbeeld door de samenvoeging van concepten uit verschillende vakgebieden die in de praktijk naast elkaar gebruikt worden), oefening leidt op den duur tot automatisering (Elshout, 1981). Ondanks de ogenschijnlijke eenvoud van de inrichting van het leerproces is het toch naar inschatting voor de docent de moeilijkste leervorm om te begeleiden. Immers, in de feedback kunnen alle hierboven genoemde aspecten aan de orde komen: het cognitief proces, de analyse van de probleemstructuur en de structuur van 
de onderliggende kennis. Vanwege de directe aansluiting bij de (umeke) ervaringen van de student zal de interactie tussen student en docent meestal een dialoogvorm hebben waarin deze aspecten aan de orde komen. Naast de expertise op het vakgebied moet de docent dus beschikken over voldoende deskundigheid om dit leerproces te begeleiden.

Het gebruik van modellen in het ondenwijsleerproces. Niet alleen de hoge eisen met betrekking tot de didactische vaardigheden van de docent in ervaringsleren, maar ook de praktisch beperkte mogelijkheden (financieel, mankracht) van de toepassing van deze onderwijsleermethode, stimuleert de ontwikkeling van specifieke leermiddelen ter ondersteuning van het leren probleemoplossen. Computerondersteund onderwijs (COO) behoort tot deze categorie. In principe heeft men hoge verwachtingen van deze methode, maar deze zijn nog lang niet ingelost. Eenvoudige computerprogramma's zoals "drill \& practice-programma's" zijn, zoals de benaming al aangeeft, in beperkte mate geschikt voor de complexe processen die aan het leren probleemoplossen ten grondslag liggen. Dergelijke programma's (vraag-antwoord-feedback, etc.) zijn eerder geschikt voor de verwerving en evaluatie van basiskennis. Bovendien zijn dergelijke programma's niet flexibel genoeg om aan te sluiten bij de reeds aanwezige kennis van de student'.

Met de ontwikkeling van expert- of kennissystemen ten behoeve van de computerondersteunde diagnostiek worden ook pogingen ondernomen deze systemen in te zetten voor onderwijs. Het gaat dus om programmatuur die niet specifiek ontwikkeld is voor het onderwijs maar daarentegen wel bruikbaar wordt geacht. Een kennissysteem is een computerprogramma waarin de kennis van één of meerdere deskundigen is opgenomen en dat in de medische praktijk bijvoorbeeld kan worden gebruikt in de computerondersteunde diagnostiek (De Witte \& Kwee, 1987 a). Het is dus een programma dat geraadpleegd kan worden door een (ervaren) gebruiker tijdens het diagnostisch proces. De beslissingsondersteunende functie is het belangrijkste gemeenschappelijke kenmerk. De programma's verschillen well in de wijze

4 Hier wordt ervaringsleren en de onderwijskundige implicaties hiervan (feedback en begeleiding) besproken met betrekking to de training in cognitieve vaardigheden. In de onderwijskundige literatuur wordt ervaringsleren echter woornamelijk ingevuld met de training in sociale vaardigheden waarbij werkvomen als "supervisie" worden besproken, het leren reflecteren van de student, etc. (Griffioen, 1980).

"In computerondersteund onderwijs wordt een onderscheid gemalakt tussen "program-control" en "student-control". Een COO-programmat dat "program-controlled" is, houdt geen rekening met de voorkennis van de gebruiker, evermin kan de gebruiker zelf het verloop van het programma beinvloeden. De tegenhanger hiervan zijn de "student-controlled" programma's. 
waarop de onderliggende kennis wordt gerepresenteerd. Vaak geven deze programma's de gebruiker ook inzicht in het beslissingsproces. Bijvoorbeeld door de meest waarschijnlijke diagnose te presenteren op elke willekeurige tussenfase in het redeneerproces. Vervolgens kan de gebruiker een toelichting vragen via een eventueel aanwezige "uitleg-functie". Als een programma deze functie kent, dus als het beslissingsproces inzichtelijk kan worden gemaakt woor de gebruiker, is het in principe ook mogelijk het programma in handen te geven van de (gevorderde) student. Invoering van gegevens die door het programma gevraagd worden en raadpleging van de door het programma gegenereerde hypothesen, eventueel gebruik makend van de uitleg-functie, laat de student als het ware meekijken over de schouder van een expert. Vanuit ons referentiekader een ideaal programma: de student krijgt inzicht in het diagnostisch proces en heeft toegang tot de onderliggende kennis die wordt gebruikt in dit proces. Het is echter een ideaalbeeld met een grove versimpeling van de onderwijspraktijk. Als een docent (expert) een student uitleg geeft over het "waarom" van zijn handelingen zall hij aansluiten bij de kennis van de student. Bovendien zal de docent zijn uitleg niet beperken tot het mededelen van de wijze waarop hij redeneert maar kan hij ook redeneren over het redeneren. Een expertsysteem ontbeert deze didactische kennis vooralsnog en daarmee is de onderwijskundige toepassing van dergelijke programmatuur zeer beperkt.

Onder de naam "intelligente COO" worden COO-programma's gerekend die bestaan uit de volgende componenten: een domeincomponent, een leerlingcomponent en een onderwijscomponent die geïntegreerd communiceren met de gebruiker via een interactiecomponent (De Witte \& Kwee, 1987 b; Sandberg en Pijls, 1989). De domeincomponent bevat alle kennis die nodig is om een probleem te kunnen oplossen: statische kennis over feiten en dynamische kennis over de wijze waarop deze feiten worden gebruikt in een redenering. De domeincomponent vormt derhalve een werkend expertsysteem zoals hierboven is besproken. Echter, in een intelligente COOtoepassing zal deze domeincomponent niet op de voorgrond actief zijn, door bijvoorbeeld zijn oplossingen en redeneringen te presenteren, maar op de achtergrond. Dat wil zeggen: de domeincomponent genereert op de achtergrond zijn eigen oplossingen en vergelijkt deze met de oplossingen van de student die worden vastgelegd in de leerlingcomponent. De domeincomponent verstrekt aldus de norm die het uitgangspunt vormt voor de vergelijking met de acties van de student. De resultaten van deze vergelijking vormen een "leerling-model" dat de invoer is van de onderwijscomponent. In deze onderwijscomponent worden beslissingsregels uitgevoerd die resulteren in acties via de interactiecomponent: uitleg, oefeningen, voorbeelden, etc. De onderwijscomponent is eigenlijk een tweede expertsysteem binnen 
het programma, het analyseert onderwijskundige problemen op basis van didactische kennis. Intelligente $\mathrm{COO}$, ook wel docentsystemen genoemd, staat nog in de kinderschoenen. Het is de fase van research nog niet ontgroeid. Een leidend voorbeeld voor deze COO-vorm is echter wel afkomstig uit het medisch onderwijs. Het expertsysteem MYCIN (diagnostiek infectieziekten) werd bewerkt tot een docentsysteem GUIDON. In de toepassing van GUTDON bleek dat de domeincomponent niet voldeed, hetgeen de basis was voor een nieuw (domein)-expertsysteem NEOMYCIN (Clancey, 1987). Hiermee wordt dus het accent gelegd op de verbetering van de domeincomponent. Wellicht niet ten onrechte, omdat verwacht mag worden dat de onderwijscomponent en de leerlingcomponent van intelligente COO-programma's in zekere mate onafhankelijk ontwikkeld kunnen worden van de component die domeinspecifieke kennis bevat. Dit is de basis voor het zoeken naar zogenaamde "lege" docentsystemen waarin de onderwijscomponent en de domeincomponent ingebracht kan worden. Een voorbeeld van een onderwijscomponent zou een simulatie kunnen zijn van een Socratische dialoog waarin, met een beperkt aantal vragen, de student geleid wordt tot begripsverheldering (Collins, 1977; Collins \& Stevens, 1983). Aan een domeincomponent stellen Sandberg en Pijls (1989) de volgende eisen: 1. De kennis moet zodanig georganiseerd zijn dat het mogelijk is de leerling uitleg over deze kennis te geven. 2. De kennis moet georganiseerd zijn naar de moeilijkheidsgraad voor de leerling en niet, zoals in expertsystemen, naar de moeilijkheidsgraad voor het systeem. 3. De kennis moet zo gestructureerd zijn dat het mogelijk is het gedrag van de leerling te vergelijken met de oplossingsstrategie van een expert. 4. De kennis moet zo georganiseerd zijn dat alleen oplossingsstrategieën gebruikt worden die ook voor mensen hanteerbaar zijn. 5. De oplossingsstrategieën moeten niet alleen correcte oplossingen kunnen genereren, maar ook incorrecte die van dezelfde aard zijn als de student die mogelijkerwijs zou kunnen hanteren. De stand van zaken echter is, zoals gezegd, dat dergelijke systemen nog in een onderzoeksfase verkeren. Dit onderzoek hoeft niet alleen te resulteren in direct toepasbare COO-programmatuur voor de onderwijspraktijk. De formalisering van het leerproces en onderwijskundige interventies kunnen ook inzichten opleveren die toepasbaar zijn in de "gewone" onderwijspraktijk. 


\section{SAMENVATTING}

In dit proefschrift worden de resultaten van vier deelstudies gerapporteerd over de rol van domeinspecifieke kennis in de vaardigheid in het oplossen van problemen. Het praktijkveld dat werd onderzocht is de fysiotherapeutische diagnostiek. Het onderzoek werd uitgevoerd in het fysiotherapieonderwijs. Studenten in een beroepsopleiding moeten een grote hoeveelheid kennis tot zich nemen. Het leerproces strekt zich daarbij uit over jaren. In de opleiding tot fysiotherapeut wordt in het algemeen twee en half jaar besteed aan de basisvorming ter voorbereiding op een stageperiode van een half jaar. Het vierde jaar in de opleiding tot fysiotherapeut wordt besteed aan verdere verdieping en afronding van het leerproces waarna men beginnend beroepsbeoefenaar is. Het gehele opleidingstraject staat dus in het licht van de voorbereiding op de intreding in de praktijk van zelfstandige beroepsuitoefening. Een algemeen gehanteerd principe in de inrichting van het beroepsvoorbereidend onderwijs is de beroepsuitoefening te analyseren in een conglomeraat van vaardigheden die hun weerslag vinden in het totale curriculum.

In Hoofdstuk 1, de inleiding op de afzonderlijke studies, wordt een drietal vaardigheidsgebieden onderscheiden in de fysiotherapeutische beroepsuitoefening: cognitieve vaardigheden, technische vaardigheden en sociale vaardigheden. Het onderzoek van een patiënt ter voorbereiding op de behandeling doet een beroep op alle genoemde vaardigheden maar, gelet op de invalshoek van het hier gerapporteerde onderzoek naar de rol van kennis, worden hier uitsluitend de cognitieve vaardigheden nader geanalyseerd. Observaties van de medische beroepsuitoefening resulteerden in een beschrijving van de volgende fasen in het diagnostisch proces: 1. Informatiewaarneming, 2. Hypothesevorming, 3. Informatie-verwerving, 4. Probleemformulering en 5. Diagnostische beslissing. Dit model van het medisch diagnostisch proces werd ook gebruikt in onderzoek naar de fysiotherapeutische diagnostiek. Daarin werd gevonden dat, met betrekking tot het diagnostisch proces, de medische en fysiotherapeutische beroepsuitoefening in hoge mate vergelijkbaar zijn. Aangezien het medisch probleemoplosisen een lange onderzoekstraditie heeft en de fysiotherapeutische diagnostiek in veel mindere mate onderzocht is, zeker vanuit onderwijskundige vraagstellingen, kan in de verantwoording van de opzet van de afzonderlijke studies aansluiting worden gezocht met relevante studies in het medische domein. In het diagnostiseren wordt kennis gebruikt van een tweetal typen: 1. Metho- 
dische kennis (kennis over de wijze waarop het diagnostisch proces optmaal verloopt) en 2. Inthoudelijke kennis. Het is naar verwachting met name de inhoudelijke kennis (kennis over ziekten/aandoeningen en onderliggende pathofysiologische processen) die een rol speelt in de accuraatheid van de diagnostiek. Vanuit verschillende invalshoeken werden onderzoeken besproken die deze stellingname ondersteunen. In de eerste plaats werd in het medisch onderwijs vastgesteld dat gedurende de opleiding de studenten steeds beter gaan diagnostiseren terwijl daarentegen de structuur wan het diagnostisch proces tijdens de studie niet fundamenteel verandert. Ook beginnende studenten onderzoeken een patiënt vanuit eén of meerdere hypothesen, echter de kwaliteit van de hypothesen neemt gedurende de opleiding toe. Omdat ook de omvang van inhoudelijke kennis toeneemt mag verondersteld worden dat de probleemoplosvaardigheid overwegend kan worden verklaard uit de beheersing van inhoudelijke kennis. In de tweede plaats werd een onderzoek besproken waarin ervaren artsen verschillende casus kregen gepresenteerd waarbij hun prestaties in de verschillende casus werden vergeleken. Het bleek nu dat probleemoplossend gedrag van dezelfde personen in sterke mate variabel is. Variabelen onder andere als tijdsduur, hoeveelheid waargenomen informatie en efficiency kenden lage correlaties tussen de verschillende metingen. Ook hier werd vermoed dat de beheersing van (sub)domeinspecifieke kennis een sterke rol speelt in de diagnostische vaardigheid. De derde invalshoek van waaruit de kennisafhankelijkheid van probleemoplossen wordt geponeerd is de analyse van gemaakte fouten in het diagnostisch proces. Twee typen fouten werden onderscheiden: 1 . de formulering van een verkeerde hypothese en 2 . foutieve evaluatie van gegevens tijdens het diagnostisch proces. In beide gevallen kan er sprake zijn van onvoldoende precisie in de kennis met betrekking tot de ziekte die gediagnostiseerd had moeten worden.

In Hoofdstuk 2 wordt een studie gerapporteerd naar de sterkte van het verband tussen de beheersing van inhoudelijke kennis en probleemoplosvaardigheid. Voor de meting van de probleemoplosvaardigheid werden casus gebruikt waarbij in een boekje een zo compleet mogelijke beschrijving werd gegeven van de informatie die gebruikt kon worden in de formulering van een diagnose. Daamaast werd op basis van de inhoud van de casus een toets samengesteld die alle specifieke kennis bevat die relevant is voor de diagnose. De instrumenten bestrijken dus hetzelfde inhoudelijke domein. De hypothese die getoetst wordt is de volgende: "Tussen de scores van kennistoetsen en probleemoplostoetsen met inhoudelijke verwantschap bestaat een sterker verband dan tussen de scores van probleemoplostoetsen onderling". De proefpersonen, derdejaars studeriten fysiotherapie, kregen twee casus gepresenteerd en twee daarvan afgeleide kennistoetsen. Een lage correlatie 
tussen de diagnose-scores van beide casus werd verwacht, en ook gevonden, op basis van de veronderstelling dat niet de beheersing van methodische kennis maar de beheersing van inhoudelijke kennis een sterke rol speelt in de diagnostiek. Er was echter geen sprake van een hogere correlatie tussen kennis-scores en diagnose-scores. In beide gevallen was het verband tussen kennisbeheersing en probleemoplosvaardigheid nagenoeg even sterk als tussen beide metingen van de probleemoplosvaardigheid. Kortom, in de eerste studie werd een zwak verband gevonden tussen de mate van kennisbeheersing en probleemoplosvaardigheid. Omdat de metingen in deze studie een globaal karakter hadden - er werd een verband gezocht tussen meetresultaten op schaalniveau - werd een tweede studie uitgevoerd waarin de specificiteit van de metingen en analyses werden verhoogd.

In Hoofdstuk 3 wordt een studie gerapporteerd warin opnieuw het verband werd onderzocht tussen kennisbeheersing en probleemoplosvaardigheid. Door de gepresenteerde problemen te beperken in omvang en complexiteit kon het verband tussen kennis en probleemoplossen worden berekend op item-niveau. Op basis van de veronderstelling dat de aanwezigheid van relevante kennis in overwegende mate bepalend is voor de mate van succes in het oplossen van een probleem werden drie, onderling samenhangende, hypothesen getoetst: Bij afwezigheid van kennis is de kans hoog dat een probleem fout wordt opgelost. Bij aanwezigheid van kennis is de kans hoog dat een probleem goed wordt opgelost. Bovendien werd een hoge correlatie verwacht tussen het antwoordgedrag op een kennisitem en het antwoordgedrag op een probleemitem. Voor de meting van probleemoplossen werd een toets samengesteld met een verzameling beknopte problemen. Op basis van deze probleemoplostoets werd een kennistoets samengesteld waarbij elk probleemitem inhoudelijk correspondeerde met enkele kennis-items. Ook in deze studie werden lage correlaties gevonden tussen kennisbeheersing en probleemoplosvaardigheid. De gedetailleerde vergelijking van de aan- of afwezigheid van kennis met de toepassing daarvan had als resultaat dat beide kansverwachtingen rondom de toevalswaarde varieerden waarbij de gemiddelde kans op een foute probleemoplossing bij afwezigheid van kennis in lichte mate hoger was dan de gemiddelde kans op een goede probleemoplossing bij aanwezigheid van kennis. In de literatuur werden soortgelijke resultaten gevonden waarbij het zwakke verband tussen kennis en probleemoplossen werd verklaard uit het achterwege blijven van kennisactivatie tijdens het denkproces. De conclusie die hieruit werd getrokken is dat de activatie van kennis een mogelijk intermedièrende rol heeft gespeeld in de bepaling van het verband tussen kennisbeheersing en probleemoplosvaardigheid. 
Hoofdstuk 4 is het verslag van een experiment waarin getracht werd het verband tussen kennisbeheersing en probleemoplosvaardigheid te versterken. Indien kennis niet wordt geactiveerd in het probleemoplossingsproces zullen de concepten ook geen deel uitmaken van de probleemrepresentatie die de grondslag vormt van de probleemoplossing. Omdat kennis blijkbaar wel anwezig kan zijn in het geheugen maar daarentegen niet wordt gebruikt zou het mogelijk moeten zijn, zo is het uitgangspunt van het experiment, om het verband tussen kennisbeheersing en probleemoplosvaardigheid te verhogen door proefpersonen hulp te bieden in de vorming van de probleemrepresentatie. De wijze waarop deze hulp werd geboden is de aanreiking van een analogie. De experimentele groep proefpersonen bestudeerde een tweetal casusbeschrijvingen waarin een analoog principe was verwerkt. Dit principe betrof het onderscheid dat gemaakt moest worden in de criterium-casus tussen chronische en acute symptomen en het oorzakelijk verband tussen beide groepen symptomen. De controle-groep kreeg deze informatie niet. In de tekst van de criteriumcasus werd de experimentele groep erop gewezen de eerder bestudeerde analogie te gebruiken. Voor de rest was de opzet van deze studie gelijk aan de opzet van de twee voorgaande studies. Ook nu werd de casus geanalyseerd op de onderliggende specifieke kennis die gebruikt moest worden in de diagnostiek. De aanwezigheid van deze kennis werd gemeten in een afzonderlijke kennistoets die voor beide groepen gelijk was. Ook de resultaten van deze metingen werden op gelijke wijze geanalyseerd als in beide voorgaande studies. Opnieuw werden correlaties berekend tussen kennisbeheersing en probleemoplosvaardigheid waarbij nu de resultaten van controle-groep en experimentele groep met elkaar werden vergeleken. Uit deze vergelijking bleek dat de experimenteel beoogde kennisactivatie niet tot stand was gekomen. Ook in deze studie werden lage correlaties gevonden tussen kennisbeheersing en probleemoplosvaardigheid. Dit betekent dat, ondanks de hulp van een analogie, de proefpersonen uit de experimentele groep de aangeboden probleeminformatie niet beter interpreteerden in het kader van reeds aanwezige kennis in het geheugen. De analogie was erop gericht de probleeminformatie zodanig te structureren dat aansluiting kon worden gevonden met bruikbare kennis in het geheugen. Uit het feit dat deze aansluiting niet tot stand kwam werd de veronderstelling afgeleid dat de langs experimentele weg gesuggereerdeprobleemstructurering in onvoldoende mate aansloot bij de individuele kennisstructuren van de probleemoplossers.

Hoofdstuk 5 bevat het verslag van een gedetailleerde studie naar het verband tussen kwalitatieve kenmerken van kennis en probleemoplosvaardigheid. In de vierde studie werden eerst de probleemrepresentaties van negen proefpersonen bij vier probleemtaken geanalyseerd. Nagegaan werd 
in hoeverre er relaties bestonden tussen kenmerken van die probleemrepresentaties en de daarbij behorende goede of foute oplossingen. Verondersteld werd dat de samenhang tussen kennis en probleemoplossen tot uitdrukking zou moeten komen in de aard van de resulterende representatie. Er werden duidelijke verschillen in probleemrepresentaties gevonden bij goede en foute oplossingen. Bij een goede oplossing bevatte de probleemrepresentatie meer diagnostisch relevante informatie. Naast de verschillende probleemrepresentaties werd daarom kennis, waarvan verondersteld werd dat ze geactiveerd was tijdens het oplossen van de problemen, onderworpen aan een contrastanalyse ten aanzien van een aantal kwalitatieve kenmerken. De gegevens waarop deze analyse werd uitgevoerd werden verkregen via een free recallopdracht om alle kennis die men zich met betrekking tot de te diagnostiseren aandoeningen wist te herinneren, te reproduceren. De kwalitatieve kenmerken waarop deze kennisprotocollen werden onderzocht waren: de relevantie van de gereproduceerde concepten in het licht van de diagnose, de conceptuele structuur van de gereproduceerde kennis en de mate van proceduralisatie van de gereproduceerde kennis. De kennisprotocollen behorende bij goede diagnoses bleken vergelijkenderwijs in sterkere mate deze kenmerken te bezitten. Goede diagnoses gingen gepaard met meer geïntegreerde kennis. De analysemethoden die in de vierde studie werden toegepast werden ontleend aan studies binnen het zogenaamde expert-noviet paradigma. Dat paradigma wordt gebruikt bij onderzoek naar de ontwikkeling van kennis gedurende een lang leerproces, over jaren. Vanwege de lange duur van zo'n leerproces worden groepen proefpersonen onderzocht die heterogeen zijn met betrekking tot hun niveau van ontwikkeling. In de vierde studie werd echter een homogene groep (derdejaars studenten) onderzocht. Uit het feit dat, net als in veel onderzoek naar verschillen tussen experts en novieten, verbanden werden gevonden tussen kwalitatieve kenmerken van kennis en probleemoplosvaardigheid, kan worden afgeleid dat de kennis van de verschillende proefpersonen, maar ook binnen de proefpersonen over de verschillende onderwerpen, in een verschillende ontwikkelingsfase verkeerde. Dit is de hoofdconclusie uit de resultaten van de vierde studie: de kennisafhankelijkheid van probleemoplossen wordt niet alleen bepaald door de mate van kennisbeheersing maar ook door de mate waarin kennis zich heeft ontwikkeld. Deze verschillen in ontwikkelingsfasen zijn blijkbaar in hoge mate subdomeingebonden aangezien in de laatste studie een verband werd gevonden tussen kennis en probleemoplossing: een student kan binnen het domein fysiotherapie kennis toepassen uit verschillende subdomeinen (bijvoorbeeld rugklachten, schouderklachten, etc.) die onderling kunnen verschillen in hun mate van ontwikkeling. 
In Hoofdstuk 6 worden enkele conclusies getrokken woor de inrichting van het onderwijs dat gericht is op cognitieve vaardigheden. Voorbereidend hierop worden eerst de resultaten van de afzonderlijke studies integraal bediscussieerd binnen het begrippenkader van geheugentheoretisch laboratoriumonderzoek. Bovendien wordt een schets gegeven van de ontwikkeling die individuele kennis ondergaat gedurende een leerproces met lange tijdsduur. Vanuit de primaire verwerving in de basisvakken verandert de kennis onder invloed van ervaring met betrekking tot niveau en representatie. Daarbij wordt de kennis ge(her)structureerd rond ziekten en aandoeningen zoals deze in de praktijk worden gediagnostiseerd. In de inrichting van het onderwijsleerproces moet rekening worden gehouden met de ontwikkeling van kennis die per individu, maar ook binnen het individu per subdomein, kan verschillen. De aspecten van het onderwijsleerproces die in de afrondende conclusies belicht worden zijn: met betrekking tot de leerstof het onderwijs in cognitieve processen en het leren analyseren van problemen; met betrekking tot de onderwijsmethode het leren door praktijkervaringen, de interactie student-docent en de vormgeving van leermiddelen, waarbij met name aandacht wordt geschonken aan de mogelijkheden en beperkingen van computerondersteund onderwijs in cognitieve vaardigheden. 


\section{SUMMARY}

This thesis reports the results of a project consisting of four studies investigating the role of domain specific knowledge in problem-solving. The domain of practice in problem-solving studied is diagnostics in physical therapy. The research project was performed in physical therapy education. Students in occupational education have to acquire a large amount of knowledge. The formal learning process ranges over four years. In physical therapy education two and a half years are spent on the introduction to basic knowledge in preparation of a probationary term of a half year. The fourth year of the curriculum is spent in further deepening and rounding off the formal learning period after which one becomes a beginning professional. The complete learning route can be looked upon as preparation for entrance to independent professional practice. A generally accepted principle in organizing such education is the analysis of professional practice into a conglomeration of specific skills each of which has an impact on the complete curriculum.

In Chapter 1, the introduction to the project's four studies, three domains of competence in the practice of physical therapy are identified: cognitive skills, technical skills and social skills. The examination of a patient before treatment applies to all three skill domains mentioned, but because of the practical need to restrict the research to the role of knowledge, exclusively cognitive skills are further analyzed.

Observations in medical practice resulted in a description of five stages in the diagnostic process: 1. Perception of information, 2. Generation of hypotheses, 3. Acquisition of further information, 4. Problem formulation and 5. Diagnostic decision. This model of the medical diagnostic process has also been used in studies of diagnostic skills in physical therapy. In this it appeared that, concerning the diagnostic process, professional activities in medicine and physical therapy are to a high degree uniform. Since medical problem-solving has a long research tradition and diagnostic skills in physical therapy have only been examined to a lesser degree, certainly in the context of educational questions, the research outcomes in the medical domain can be generally applied. In diagnostics knowledge use is made up of two categories: 1. Methodic knowledge (knowledge about the way the diagnostic process optimally proceeds) and 2 . Substantial knowledge. It is anticipated that substantial knowledge in particular (knowledge about diseases and afflictions, their symptoms and underlying pathophysiological proces- 
ses) plays a prominent role in diagnostic accuracy. Studies were discussed from different viewpoints which support this expectation. It has been found that medical students during their course of training improve in diagnostic skills although the diagnostic process does not change fundamentally.

Even beginning students examine a patient with one of several hypotheses in mind; however, the quality of their hypotheses increases during training. Also since the amount of substantial knowledge increases, it might be hypothesized that problem-solving skills can be interpreted predominantly in terms of mastery of substantial knowledge. Second, a study was examined in which experienced physicians diagnosed several cases and their behavior across cases was compared. Results suggested that the problemsolving behavior of the same persons varies to a high degree. Variables such as time of generation of first hypothesis, percentage of cues acquired and efficiency correlated poorly with each other across the different observations. In this study it was supposed that mastery of (sub)domainspecific knowledge plays a dominant role in diagnostic competence.

The third point of view in which the knowledge dependency in problem-solving was hypothesized is in the analysis of errors in the diagnostic process. Two categories of errors were differentiated: 1. Generation of an incorrect hypothesis and 2. Inaccurate evaluation of cues in diagnostic process. Both categories could be the consequence of insufficient precision in the knowledge of the diseases which have to be diagnosed.

Chapter 2 is the report of a study on the strength of the association between mastery of substantial knowledge and problem-solving. To measure competency in problem-solving, cases were used in the format of a booklet in which a complete description was given of the information that could be used in the diagnosis. From an examination of the content of the cases a knowledge test was created which included all specific items relevant for diagnosis of the cases. Thus, the measuring-instruments covered the same subject matter of a subdomain.

The following hypothesis was tested: The scores of knowledge tests and problem-solving tests concerned with the same subject matter are more strongly associated than the scores of the problem-solving tests are to one another. The testees were students in the third year of the curriculum. They diagnosed two cases and completed two knowledge tests. A low correlation between the diagnosis-scores of the two cases was anticipated, and actually found, based on the assumption that it was not the mastery of methodic knowledge but the mastery of substantial knowledge that plays a prominent role in diagnostic competence. However, correlations between knowledgescores and diagnosis-scores were no higher. In both assessments, the association between mastery of knowledge and problem-solving skill was nearly 
equal to the weak association between problem-solving scores. In short, in the first study, a weak association was found between mastery of substantial knowledge and problem-solving skill. The assessments in this study were on a global level, on the level of scales. Therefore, a second study was performed in which both the specificity of assessments and analyses were increased.

Chapter 3 is the report of this study in which the association between mastery of knowledge and problem-solving skill was explored once more. Through reduction of the amount of problem information and complexity in each case the association between knowledge and problem-solving was analyzed item by item. Based on the assumption that presence of relevant knowledge determines to a high degree the amount of success in problemsolving, three mutually connected hypotheses were tested: In the absence of knowledge there is a high probability that a problem will be solved incorrectly. In presence of knowledge there is a high probability that the problem will be solved correctly. Additionally a high positive correlation was anticipated between response behaviour on a knowledge-item and response behaviour on a problem-item.

To assess problem-solving, a test was constructed with a collection compact problems. From this problem-solving test a knowledge test was inferred in which one or two knowledge-items covered one problem-item. As well, in this study, low correlations were found between mastery of knowledge and problem-solving competence. The detailed comparison of absence and presence of knowledge with utilization indicated that both probability-anticipations fluctuated around chance probability. The mean probability of an incorrect problem solution in absence of knowledge was slightly higher than the mean probability of a correct problem solution in presence of knowledge. In the literature findings of the same kind were reported in which the weak association between knowledge and problemsolving was indicated. This was interpreted as the failure of activation of knowledge in the reasoning process. It was concluded that activation of knowledge could intervene between mastery of knowledge and problemsolving competence.

Chapter 4 is the report of an experiment in which attempts ware made to strengthen the association between knowledge and problem-solving stronger. If knowledge is not activated in the problem-solving process, concepts will not form part of the problem representation which is the foundation of the problem solution. Because knowledge can be present in memory but, on the contrary is not used, as is the starting point of the experiment, the association between knowledge and problem-solving can be made stronger by giving a hint to the testees when they form a problem 
representation. The way which this hint was given was through the provision of an analogy. The experimental group read two case descriptions in which an analogous principle was embodied. The principles were the discrimination between chronic and acute symptoms and the causal relation between both groups of symptoms. The control group did not get this information. In the text of the criterion case, the experimental group was directed to use the analogy which had been studied before.

For the rest the design of this study was the same as the design of the two preceding studies. In this study as well a case was analyzed to determine the specific underlying knowledge which had to be applied in coming to the correct diagnosis. The presence of this knowledge was assessed in a separate knowledge test equal for both groups. The results of these assessments were analyzed in the same way as before. Again, correlations were computed between mastery of knowledge and problem-solving in order to compare the control and experimental groups. In this comparison it appeared that the intended activation of knowledge was not achieved. Also, in this study, low correlations were found between mastery of knowledge and problem-solving skill. This implies that, despite the availability of assistance by means of an analogy, testees in the experimental group did not interpret the problem information provided better in the framework of present knowledge in memory. The analogy was focussed so as to rearrange the problem information in such a way that a connection could be made with applicable knowledge in memory. Because this intended connection was not achieved, it was assumed that the experimentally suggested problem structure insufficiently matched the problem solvers" individual knowledge structures.

Chapter 5 is the report of an exhaustive study on the association of qualitative features of knowledge with problem-solving skill. In the fourth study, the problem representations of nine testees in four different cases were analyzed. Associations between features of the problem representation. and the correctness of the problem solution were traced. It was hypothesized that the association between knowledge and problem-solving would be expressed in the character of the concluding representation. Uncontaminated differences were found in representations associated with correct or incorrect solutions. Concerning a correct diagnosis the problem representation included more diagnostic relevant information. In addition to different problem representations, knowledge, which was supposed to be activated during problem-solving, was subrnitted to a contrast-analysis for numeral qualitative features. The data for this analysis were acquired by free recallinstructions to reproduce all knowledge which could be remembered regarding the afflictions which had to be diagnosed. The qualitative features used 
to analyse the knowledge protocols were: the diagnostic relevance of the reproduced concepts, the conceptual structure of the reproduced knowledge and the degree of knowledge proceduralization. It appeared that the protocols associated with correct diagnoses held these features to a comparatively higher degree. Correct diagnoses were associated with more integrated knowledge. The methods of analysis which were applied in the fourth study were directly derived from studies in the so called expert-novice paradigm. This paradigm has been used in research in the development of knowledge across a lengthy process of learning, that means over years. Because of long intervals in the learning process, groups heterogeneous in terms of developmental level are examined. However, in the fourth study, a homogeneous group (third year students) was studied. The results here indicated, as in findings of many studies on the differences between experts and novices, that there is an association between qualitative features of knowledge and skill in problem-solving. These findings suggest that the knowledge possessed by different testees, and also knowledge within testees across different subdomains, can be at different stages of development. Thus the main conclusion of the fourth study is that the knowledge dependency of problem-solving is not only defined by knowledge mastery but also by the degree to which this knowledge has developed. Developmental stages are apparently subdomain related since in the last study an association was found between knowledge and problem solution: a student in the domain of physical therapy can apply knowledge of different subdomains (for example complaints of back pain, shoulder pain, etc.) which can differ mutually across stages of development.

In Chapter 6 the implications for the design of education in cognitive skills are discussed. First the results of the individual studies are discussed together in the framework of concepts belonging to theoretical laboratoryexperiments of human memory. Further, a rough outline is given of the development of individual knowledge during a lengthy learning process. After initial acquisition of knowledge within the context of basic disciplines, this knowledge is modified with respect to level and representation affected by experience. Initial knowledge is restructured in knowledge about diseases and afflictions as they are diagnosed in practice. The individually differing developmental stages of knowledge have to be considered in the arrangement of the teaching-learning process. The central topics of the teaching-learning process are highlighted: a. with respect to subject matter the teaching of cognitive processes and of problem analysis; and $b$. with respect to the teaching-method, learning by doing, the interaction between teacher and student and the design of tools for learning. The possibilities and restrictions of computer based training of cognitive skills are given particular attention. 


\section{LITERATUUR}

Anderson, J.R. (1982). Acquisition of cognitive skill. Psychological Review, 89, 369 406.

Anderson, J.R. (1983). The architecture of cognition. Cambridge,MA: Harvard University Press.

Anderson, J.R. (1987). Skill acquisition: compilation of weak-method problem solutions. Psychological Review, 94, 192-210.

Anderson, J.R., Greeno, J.G., Kline, P.J. \& Neves, D.M. (1981). Acquisition of problem-solving skill. In: Anderson, J.R. (Ed), Cognitive skills and their acquisition. Hillsdalle, NJ: Erlbaum, 191-231.

Andrews, D.H. \& Goodson, L.A. (1986). A comparative analysis of models of instructional design. Journal of Instructional Development, 3, 2-16.

Barrows, H.S. \& Tamblyn, R.M. (1980). Problem-based learning: An approach to medical education. New York: Springer.

Beck, A.L. \& Bergman, D.A. (1986). Using structured medical information to improve students' problem-solving performance. Journal of Medical Education, 61, 749756.

Beveridge, M. \& Parkins, E. (1987). Visual representation in analogical problem solving. Memory \& Cognition, 15, 230-237.

Boshuizen, H.P.A. (1989) De ontwikkeling van medische expertise: Een cognitief-psychologische benadering. Academisch proefschrift RL, Maastricht.

Boshuizen, H.P.A. \& Schmidt, H.G. (1990). Causal reasoning and biomedical knowledge in medical diagnosis. (in voorbereiding).

Bransford, J.D. \& Johnson, M.K. (1972). Contextual prerequisites for understanding: Some investigations of comprehension and recall. Journal of Verbal Learning and Verbal Behavior, 11, 717-726.

Bransford, J., Sherwood, R., Vye, N. \& Rieser, J. (1986). Teaching thinking and problem solving. American Psychologist, 41, 1078-1089.

Bransford, J.D., Sherwood, R.D. \& Sturdevant, T. (1987). Teaching thinking and problem solving. In: Baron, J. \& Sternberg, R.J. (Eds.) Teaching thinking skills: theory and practice, New York: Freeman, 162-181.

Braune, R. \& Foshay, W.R. (1983). Towards a practical model of cognitive/information processing task analysis and schema acquisition for complex problem-solving situations. Instructional Science, 12, 121-145.

Cazden, C.B. (1976). Implications for instructional research. In: Klahr, D. (Ed.), Cognition and instruction. Hillsdale, NJ: Erlbaum, 317-323.

Chase, W.G. \& Simon, H.A. (1973) The mind's eye in chess. In: Chase, W.G. (Ed.), Visual information processing. New York: Academic Press.

Chi, M.T.H., Feltovich, P.J. \& Glaser, R. (1981). Categorization and representation of physics problems by experts and novices. Cognitive Science, $5,121-152$.

Chi, M.T.H., Glaser, R. \& Rees, E. (1982). Expertise in problem solving. In: Sternberg, R.J. (Ed.), Advances in the psychology of human intelligence, Volume 1. Hillsdale, NJ: Erlbaum, 7-75.

Chiesi, H.L., Spilich, G.J. \& Voss, J.F. (1979). Acquisition of domain-related information to high and low domain knowledge. Journal of Verbal Learning and Verbal Behavior, 18, 257-273. 
Clancey, W.J. (1987). Methodology for building an intelligent tutoring system. In: Kearsley, G.P. (Ed), Artificial intelligence \& instruction: Applications and methods. Reading, MA: Addison Wesley, 193-228.

Collins, A. (1977). Processes in acquiring knowledge. In: Anderson, R.C., Spiro, R.J. \& Montague, W.E., Schooling and the acquisition of knowledge. Hillsdale, NJ: Erlbaum, 339-363.

Collins, A. \& Stevens, A.L. (1983). A cognitive theory of inquiry teaching. In: Reigeluth, C.M. (Ed) Instructional-design theories and models: An overview of their current status. Hillsdale, NJ: Erlbaum, 247-278.

Corte, E. de, Geerligs, C.T., Lagerwey, N.A.J., Peters, J.J. \& Vandenberghe, R. (1973). Beknopte didaxologie. Groningen: Tjeenk Willink.

Coughlin, L.D. \& Patel, V.L. (1986). Text comprehension and the effect of expertise in the domain of medicine. Annual meeting of the American Educational Research Association. San Francisco.

Curtis, R.V. \& Reigeluth, C.M. (1984). The use of analogies in written text. Instructional Science, 13, 99-117.

Derijcke, J.C.J., Emst, H.H. \& Vinck, A.F.E.I. (1981), De zorg om de kwaliteit van de zorg in de fysiotherapie. Nota ter gelegenheid van eerste lustrum van de Landelij$k e$ Vereniging voor Fysiotherapeuten in Dienstverband.

Derijcke, J.C.J., Ernst, H.H. \& Vinck, A.F.E.I. (1982). Over het hanteren van kriteria en normen bij het fysiotherapeutisch onderzoek en het fysiotherapeutisch behandelplan. Nederlands Tijdschrift woor Fysiotherapie, 92, 326-333.

Dijkstra, S. (1986). De psychologie van het leren en de vormgeving van instructie. In: Dijkstra, S. \& Span, P. (Eds.), Leerprocessen en instructie. Lisse: Swts \& Zeitlinger, 3-15.

Dijkstra, S., Stelt, P.F. van der \& Sijde, P.C. van der (1983). Het effect van verschillende expertiseniveau's op de interpretatie van tandheelkundige foto's. In: Beishuizen, J.J. (Ed.), Onderwijsleerprocessen: Tekstverwerking, problemen oplossen en leermoeilijkheden. Lisse: Swets \& Zeitlinger.

Domaracki, J. \& Ohnmacht, F. (1986). Reading and change in knowledge structure. Annual Meeting of the American Educational Research Association. San Francisco.

Duncker, K. (1945). On problem solving. Psychological Monographs, 58, (No. 270).

Ekwo, E.E. \& Loening-Baucke, V. (1979). Clinical problem solving and clinical knowledge. Medical Education, 13, 251-256.

Elshout, J.J. (1981). Het leren oplossen van problemen. Losbladig Onderwijskundig Lexicon. PO 4230, 1-13.

Elstein, A.S." Shulman, L.S. \& Sprafka (1978). Medical problem solving. An analysis of clinical reasoning. Cambridge, MA: Harvard University Press.

Elstein, A.S., Sprafka, S.A. \& Bordage, G. (1979). Problem solving: applications of research to undergraduate instruction and evaluation. Programmed Learning and Educational Technology, 16, 296-302.

Feltovich, P.J., Johnson, P.E., Moller, J.H. \& Swanson, D.B. (1984). LCS: The role and development of medical knowledge in diagnostic expertise. In: Clancey, W.J. \& Shortliffe (Eds.), Readings in medical artificial intelligence: The first decade. Cambridge, MA: Addison-Wesley, 275-319.

Finegolld, M. \& Mass, R. (1985). Differences in the processes of solving physics problems between good physics problem solvers and poor physics problem solvers. $R e$ search in Science \& Technological Education, 3, 59-67. 
Frederiksen, N. (1984). Implications of cognitive theory for instruction in problem solving. Review of Educational Research, 54, 363-407.

Gale, J. \& Marsden, P. (1982). Clinical problem solving: the beginning of the process. Medical Education, 16, 22-26.

Gale, J. \& Marsden, P. (1983). Medical diagnosis. London, Oxford University Press.

Gentner, D. (1983). Structure-mapping: A theoretical framework for analogy. Cognitive Science, $7,155-170$.

Gentner, D. \& Gentner, D.R. (1983). Flowing waters or teeming crowds: mental models in electricity. In: Gentner, D. \& Stevens, A.L. (Eds.), Mental models. Hillsdale, NJ: Erlbaum, 99-129.

Gentner, D. \& Toupin, C. (1986). Systematicity and surface similarity in the develop. ment of analogy. Cognirive Science, 10, 277-300.

Gerritsma, J.G.M. \& Smal, J.A. (1982). De werkwije wan huisarts en internist: Een vergelijkend onderzoek met behwlp van een interactieve patientensimulatie. Utrecht: Wetenschappelijke uitgeverij Bunge.

Gick, M.L. (1985). The effect of a diagram retrieval cue on spontaneous analogical transfer. Canadian Journal of Psychology, 39, 460-466.

Gick, M.L. \& Holyoak, K.J. (1983). Schema induction and analogical transfer. Cognitive Psychology, 15, 1-38.

Gick, M.L. \& Holyoak, K.J. (1985). Analogical problem solwing. In: Aitkenhead, A.M. \& Slack, J.M. (Eds.), Issues in cognitive modeling, London: Erlbaum, 279-306.

Glaser, R. (1976) (a). Cognitive psychology and instructional design. In: Klahr, D. (Ed.), Cognition and instruction. Hillsdale, NJ: Erlbaum, 303-317.

Glaser, R. (1976) (b). Components of a psychology of instruction: Toward a science of design. Review of Educational Research, 46, 1-24.

Gomez, F. \& Chandrasekaran, B. (1984). Knowledge organization and distribution for medical diagnosis. In: Clancey, W.J. \& Shortliffe (Eds.), Readings in medical artificial intelligence: The first decade. Cambridge, MA: Addison-Wesley * 320338.

Grave, W.S. de (1990). Knowledge representation software as a tool for learning and research. Technical Report 1 ACISIIBM-Rijksuniversiteit Limburg.

Gregg, V. (1975). Human memory. Londen: Methuen.

Griffioen, J. (1980). Supervisie wan beginnende leraren. Groningen: Wolters Noordhoff.

Groot, A.D. (1946). Het denken wan den schaker. Den Haag: North-Holland.

Guilford, J.P \& Fnuchter, B. (1973). Fundamental statistics in psychology and education. London: MeGraw-Hill.

Gustaffsson, J.E. (1977). The Raschmodel for dichotomous items: Theoryapplications and a computerprogram. (Report no.63). Göteborg: The Institute of Education.

Hassebrock, F. \& Johnson, P.E. (1986). Medical knowledge and cognitive effort in diagnostic reasoning. Annual Meeting of the American Educational Research Association. San Francisco.

Hayes, D.A. (1986). Readers' use of analogic and visual aids for understanding and remembering complex prose. Ammal Meeting of the American Educational Research Association. San Francisco.

Hayes, D.A. \& Tierney, R.J. (1982). Developing readers' knowledge through analogy. Reading Research Quarterly, 17, 256-280. 
Holyoak, KJ. (1984). Analogical thinking and human intelligence. In: Stemberg. R.J. (Ed.), Advances in the psychology of human intelligence: Volume 2. Hillsdale, NJ: Eurlbaum, 199-231.

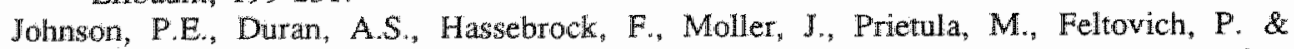
Swanson, D.B. (1981). Expertise and error in diagnostic reasoning. Cognitive Science, $5,235-283$.

Jong, A.J,M. de (1986). Kenmis en het oplossen van vakinhoudelije problemen. Academisch proefschift TUE; Eindhowen.

Jong, A.M.M. de \& Ferguson-Hessier, M.G.M. (1983). Het effect van een instructie van een strategie voor het oplossen van natuurkundige problemen door eerstejaars studenten. In: Beishuizen, J.J. (Ed.), Onderwijsleerprocessen: Tekstwerwerking. problemen oplossen en leemoeilikheden. Lisse: Swets \& Zeitlinger, 93-101.

Jong, A.J.M. de Ferguson-Hessler, M.G.M. (1984). Strategiegebruik bij het oplossen van problemen in een semantisch rijk domein: electriciteit en magnetisme. Tijdschrift voor Onderwijsresearch, 9, 3-15.

Kingma, MJ. \& Dokter, H.J. (1985). Rugping. Utrecht: Bohn, Scheltema \& Holkema.

Kintsch. W. (1974). The representation of meaning in memory. Hillsdalle, NJ: Erlbaum.

Kommers, P.A.M. (1988) (a). Textvision: Conceptual representation beyond the hypertext metaphor. European Journal of Psychology of Education, 3, 201-216.

Kommers, P.A.M. (1988) (b). Textvision: Elicitation and acquisition of conceptual knowledge by graphic representation and multiwindowing. In: Veer, G.C. \& Mulder, G. (Eds.), Human-computer interaction: Psychonomic aspects. Berlin: Springer Verlag, 237-249.

Langerak, W.F. (1979), Herkennen versus herinneren, oftewel meerkeuze- versus opstelvragen. Tijdschrift yoor Onderwijsresearch, 4, 140-143.

Larkin, J.H. (1983). The role of problen representation in physics. In: Gentner, D. \& Stevens, A.L. (Eds.), Mental models. Hillsdale, NJ: Erlbaum, 75-98.

Larkin, J.H., McDermott, J., Simon, D.P. \& Simon, H.A. (1980). Expert and novice performance in solving physics problems. Science, $208,1335-1342$.

Mayer, R.E. (1982). Memory for algebra story problems. Journal of educational Psychology. 74, 199-216.

Mayer, R.E. (1.983). Thinking, problem solving, cognition. New York: Freeman.

Mayer, R.E. (1985). Structural analysis of science prose: Can we increase problemsolving perfomance? In: Britton, B.K. \& Black, J.B., Understanding expository text. Hillsdale, NJ: Erlbaum, 65-87.

Mckeithen, K.B., Reitman, J.S., Rueter, H.H. \& Hirtle, S.C. (1981), Knowledge organization and skill differences in computer programmers. Cognitive Psyhology, 13, $307-325$.

Meyer, B.J.F. (1975). The organization of prose and its effect on memory. Amsterdam: North-Holland.

Meyer, B.J.F. \& McConkie, G.W. (1973). What is recalled after hearing a passage? Jounal of Educational Psychology, 65, 109-117.

Molenaar, I.W. (1983). Rasch, Mokken en schoolbeleving. In: Lindeman, S. \& Stokman, F.S. (Eds.), Modellen in de sociologie. Deventer: Van Loghum Slaterus, 195-213.

Montague, W.E. (1986). Application of cognitive science principles: Instructional heuristics and mechanisms for use. Ammual Meering of the American Educational Research Associarion. San Francisco. 
Neufeld, V.R., Noman, G.R., Feightner, J.W. \& Barrows, HS. (1981). Clinical problem-solving by medical students: a cross-sectional and longindinal analysis. Medical Education, 15, 315-322.

Neves, D.M. \& Anderson, J.R. (1981). Knowledge compilation: Mechamisns for the automatization of cognitive skills. In: Anderson; JR. (Ed.), Cognitive skils and their acquisition. Hillsdale, NJ: Erlbaum, 57-85.

Norcini., J.J., Meskauskas, J.A., Langdon, L.O. \& Webster, G.D. (1986). An evaluation of a computer simulation in the assessment of physician competence. Evaluation a The Health Professions, 9, 286-304.

Norman, D.A. (1978). Notes toward a theory of complex leaming. In: Lesgold, A.M., Pellegrino, J.W., Fokkema, S.D. \& Glaser, R. (Eds.), Cognitive psychology and instruction. New York: Plenum.

Norman, G.R. (1985). Defining competence: A methodological review. In: Neufeld, V.R. \& Norman, G.R. (Eds.), Assessing clinical competence. New York: Springer, 1537.

Noman, G.R, Tugwell, P. Feightner, J.W, Muzzin, L.J. \& Jacoby, L.L. (1985). Knowledge and clinical problem-solving. Medical Education, 19, 344-356.

Noman, G.R. et al. (1989). Research in the psychology of clinical reasoning: Implications for assessment. Praceedings of the Cambridge Conference $I V$. (in press).

Patel, V.L. \& Coughlin, L.D. (1986) Understanding medical text: An approach to cognitive analysis of medical discourse. Cognitive Research Series, McGill University, Montreal.

Patel, V.L. \& Frederiksen, C.L. (1984). Cognitive processes in comprehension and knowledge acquisition by medical students and physicians. In: Schmidt, H.G \& De Volder, M.L. (Eds.), Tutorials in problem-based learning. Assen: Van Grorcum, $143-166$.

Patel, V.L. \& Groen, G.J. (1986). Knowledge based solution strategies in medical reasoning. Cognitive Science, 10, $91-116$.

Patil, R.S., Szolovits, P. \& Schwartz, W:B. (1984). Causal understanding of patient illness in medical diagnosis. In: Clancey, W.J. \& Shortliffe (Eds.), Readings in medical artificial intelligence: The first decade. Cambridge, MA: Addison-Wesley, 339-360.

Payton, O.D. (1985). Clinical reasoning process in physical therapy. Physical Therapy, $65,924-928$.

Perfetto, G.A., Bransford, J.D. \& Franks, J.J (1983). Constraints on access in a problem solving context. Memory \& Cognition, $11,24-31$.

Rasch, G. (1960). Probabilistic models for some intelligence and attaiment tests. Copenhagen: The Danish Institute for Educational Research.

Reynolds, A.G. \& Flagg, P.W. (1977). Cognitive psychology. Cambridge, MA: Winthrop.

Rigney, J.W. \& Lutz, K.A. (1976). Effect of graphic analogies of concepts in chemistry on leaming and attitude. Journal of Educational Psychology, 3, 305-311.

Rijsbergen, B. van, Stam, H.N., Vrijman, J.H. \& Zalmstra, T.A.L. (1987). Methoden van fysiotherapeutisch onderzoek. Nederlands Tijdschmift voor Fysiotherapie. 97, 146151 .

Ronteltap, C.F.M., Bisscheroux, T.J.H.I. \& Rameckers, E.A.A. (1988). Diagnostiek in de fysiotherapie: methodiek en de rol van kennis. Nederlands Tijdschrift voor Fysiotherapie, 98, 167-171. 
Ronteltap, C.F.M., Dobbelaere, R.I.M.C. \& Rameckers, E.A.A. (1986). Het wak 'Onderzoeken en Behandelen" in de opleiding fysiotherapie. Nederlands Tijdschrift voor Fysiotherapie, $96,284-286$.

Royer, J.M. \& Cable, G.W. (1976). Illustrations, analogies, and facilitative transfer in prose learning. Journal of Educational Psychology, 68, 205-209.

Rumelhart, D.E. Noman, D.A. (1978). Accretion, tuning and restructuring: Three modes of learning. In: Cotton, I.W, \& Klatzky, R.L. (Eds), Semantic factors in cognition. Hillsdale, NJ: Erlbaum, 37-53.

Rumelhart, D.E. \& Noman, D.A. (1981). Analogical processes in leaming. In: Anderson, J.R. (Ed.), Cognitive skills and their acquisition. Hillsdale, NJ: Erlbaum, 335359.

Rumelliart, D.E \& Ortony, A. (1977). The representation of knowledge in memory. In: Anderson, R.C., Spiro, R.J. \& Montague, W.E. (Eds.), Schooling and the acquisttion of knowledge. Hillsdale, NJ: Erllbaum, 99-135.

Sandberg, J. \& Pijls, F. (1989). De computer onderwijst. In: Pijls, F. \& Sandberg, J. (Eds.), De computer als expert en didacticus: Een introductie in het onderzoek naar intelligente onderwijssystemen. Muiderberg: Coutinho, 8-15.

Schmidt, H.G. (1982). Activatie van voorkennis, intrinsieke motivatie en de verwerking wan tekst; Studies in probleemgestuurd onderwijs. Academisch proefschrift RL, Maastricht.

Schmidt, H.G., Boshuizen, H.P.A. \& Hobus, P.P.M. (1988). The intermediate effect in clinical case representation. Proceedings of Cognitive Science Society. Hillsdale, NJ: Erlbaum.

Schmidt, H.G. Boshuizen, H.P.A. \& Norman, G.R. (1990). Why my doctor hardly ever misses a diagnosis: Reflections on the nature of expertise in medicine. In: Grant, A. (Ed.), Advances in biomedical computing $I_{\text {. (in press). }}$

Schmidt, H.G. \& Norman, G.R. (1989). A stage theory on the development of expertise in medicine. (interne publicatie Rijkstniversiteit Limburg).

Schmidt, H.G. \& Norman, G.R. (1990). Transitory stages in the development of expertise in medicine: review of the evidence. Amnual Meeting of the American Educational Research Association. Boston.

Sellink, W. \& Wurms, R. (1986). Video en fysiotherapie-onderwijs: Eindrapport van het SAFA/IFLO/AVC-VU samenwerkingsproject "Audiovisuele programmatuur in het onderwijs van het bewegingsapparaat. SAFA, Academie voor Fysiotherapie Amsterdam.

Shiffrin, R.M. (1970). Memory search. In: Noman, D.A (Ed.), Models of human memory. New York: Academic Press; 375-447.

Shuell, T.J. (1969). Clustering and organization in free recall. Psychological Bulletin, 72 , 353-374.

Sijde, P.C. van der, Sellink, W. (1983). Ontwikkeling van audiovisuele programmatuur voor het leren oplossen van fysiotherapeutische problemen: Interim-rapport van het SAFA-IFLO samenwerkingsproject "Audiovisuele programmatuur in het onderwijsvan het bewegingsapparaat. SAFA, Academie voor Fysiotherapie Amsterdam.

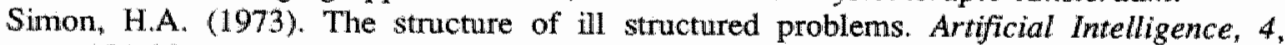
$181-201$.

Simon, H.A. (1985). Information-processing theory of human problem solving. In: Aitkenhead, A.M. \& Slack, J.M. (Eds.), Issues in cognitive modeling. London: Erlbaum, 253-278. 
Smits, A.A.W. \& Sijde, P.C. van der (1984). De invloed van fysiotherapeutische expertise op het oplossen van een schouderprobleem. Paper Onderwijsrexseafchdagen (ORD), Tilburg.

Smits, A.A.W. \& Sijde, P.C. van der (ongedateerd). Interpretatie en anticiparie in het fysiotherapeutisch probleemoplossen. SAFA, Academie voor Fysiotherapie Amster. dam.

Sowa, J.F. (1983). Conceptual structures: Information processing in mind and machine. Reading, MA: Addison-Wesley.

Spencer, R.M. \& Weisberg, R.W. (1986). Context-dependent effects on analogicall transfer. Memory \& Cognition, 14, 442-449.

Stephens, R.G. Bhaskar, R. \& Dillard, J.F. (1981). The role of task analysis in understanding problem-solving behavior. Iristructional Science, 10, 23-45.

Stemberg, RJ. (1977). Component processes in analogical reasoning. Psychological Review, $84,353-378$.

Stemberg, R.J. (1986). Cognition and instruction: why the marriage sometimes ends in divorce. In: Dillon, R.F. \& Stemberg, R.J. (Eds.), Cognition and instruction. New York, Academic Press, 375-382.

Swanson, D. (1987). A measurement framework for performance-based tests. In: Hart, I. \& Harden, R. (Eds.) Further developments in assessing clinical competence. Montreal: Heal publications.

Swanson, D., Norcini, J. \& Grosso, L. (1987). Assessment of clinical competence: written and computer-based simulations. Assessment and Evaluation in Higher Education, 12, 220-246.

Topp, B.W., Kulhavy, R.W. \& Webb, K.S. (1986). Schemata, reading and remembering: Prior knowledge effects during encoding and retrieval. Amwual meeting of the American Educational Research Association. San Francisco.

Tulving, E. \& Thomson, D.M. (1973). Encoding specificity and retrieval processes in episodic memory. Psychological Review, 80, 352-373.

Vleuten, C.P.M. van der (1990). Toetsing van medische expertise. Onderzoeksvoorstel t.b.w. Faculteit der Geneeskunde, Rijksuniversiteit Limburg, Maastricht.

Vries Robbe, P.F. de (1978), Medische besluitworming: Een aanzet tot formele geneeskunde. Academisch proefschrift $\mathbb{R U G}_{\text {, Groningen. }}$

Wickelgren, W.A. (1979). Cognitive psychology. Englewood Cliffs, NJ: Prentice-Hall.

Wilson, P.T. \& Anderson, R.C. (1986). What they don't know will hurt them: The role of prior knowledge in comprehension. In: Orasanu, J. (Ed.), Reading comprehension: From research to practice. Hillsdale, NJ: Enlbaum, 31-48.

Winkel, D. Fisher, S. \& Vroege, C. (1984). Diagnostiek: Weke delen aandoeningen van het bewegingsapparaat (deel 2). Utrecht: Bohn, Scheltema \& Holkema.

Witte, J.J.S.C. de \& Kwee, A.Y.L. (1987), Kemissystemen en medische besiuitvorming. Alphen a.d. Rijn: Samsom.

Witte, J.J.S.C. de \& Kwee, A.Y.L. (1987). Kernissystemen in het onderwijs. Alphen a.d. Rijn: Samsom.

Wright, HJ. \& MacAdam, D.B. (1982). Diagnostiek en besluitvorming: Rationele argumenten in de geneeskunde. Utrecht: Bohn, Scheltema \& Holkema.

Wulff, H.R. (1980). Principes van klinisch denken en handelen. Utrecht: Bohn, Scheltema \& Holkema. 


\title{
Bijlage 1: Casus schouderklacht en kennisitems
}

\section{ANAMNESE}

VERWIJZNNG:

- Datum:

- Naam:

- Adres:

- Geboortedatum:

- Geslacht:

- Beroep:

- Diagnose:

- Medische behandeling:

- Behandel opdracht:

- Verwijzer:

- Bijzonderheden:

- Verzekerd:

\author{
is op de dag van gisteren gedateerd \\ Hans van de Winkel \\ Ruitersweg 12, Tullburg \\ 16-2-1946 \\ man \\ glazenwasser \\ P.IIS. \\ verwijzing naar fysiotherapent \\ gaame Uw therapie. \\ huisarts \\ geen \\ particulier
}

\section{ANAMNESEGESPREK:}

Ik ben gisteren naar de dokter gegaan. Hij heeft mij naar u gestuurd. Ik ga bijna nooit naar de dokter, maar nu kan ik niet meer werken. De eerste keer dat ik wat voelde was met de verhuizing. Dat is nu 10 dagen geleden. Toen had ik 's avonds wat spierpijn rond de schouder. In de loop van de volgende dag werd het erger. Toen ik het kozijn was aan het schuren, moest ik af en toe ophouden met werken. Ik hield dan op vanwege de pijn. Ik heb me niet gestoten. Ik heb me ook niet vertild.

Een jaar gelden heb ik net zo iets gehad. Vlak voor de vakantie was dat. Toen had ik ook ontzettend hard gewekt. Toen was de pijn veel minder. Het is ook vanzelf overgegaan. Maar nu geloof ik niet dat het vanzelf overgaat. Nu werd het ook eerst wat minder, maar na enige dagen werd het weer erger.

Soms werk ik wat meer met links maar dan voel ik mijn schouder nog. Een emmer water tillen gaat nog. Maar diezelfde emmer op een tafel zetten lukt niet. De ladder optillen en glazen wassen, $k$ an ik nu niet meer. Als ik de overall in een keer ower beide schouders tegelijk aan trek dan barst ik ook van de pijn. "s Ochtends denk ik het gaat wel weer. Maar een uurtje werken en de pijn kont weer opzetten.

De pijn komt langzam opzetten. En wordt steeds scherper. Dan voel ik een stekende pijn van mijn schouder tot aan de elleboog. Ook als ik niets doe woel ik nog pijn. Wel veel minder.

Als ik op mijn schouder lig word ik er wakker van.

Soms is de nek wel eens pijnlijk en stijf. Dat is dan een keer "s awonds. Welke beweging dan het pijnlijk is? Dat weet ik echt niet. Ik heb nu geen last van de nek.

Op het ogenblik werk ik niet. Ik doe wat aan de boekhouding en rommel een beetje aan. Met de zaak ben ik 6 dagen per week bezig. Ik sta zelf elke dag tot 4 wur op de ladder. De zaak loopt goed. Maar de andere 2 jongens maken nu overuren. Ik hoop dat ik door de therapie binnen een week of 2 volledig aan de slag kan.

Met tennissen en voetballen ben ik maar gestopt. Gelukkig hebben we winterstop. 
OVERIGE GEGEVENS EN BEMNDINGEN:

- Patient heeft nooit last van hoofdpijn.

- Heeft geen last wan prikkelingen en tintelingen in de vingers.

- Heeft nooit last van iets uit zijn hander laten vallen.

- Wordt ongeveer eens per maand wakker met een gevoelloze am.

- Hij is werder zo gezond als een vis.

- Alleen van die "rot arm" daar krijgt hij wat wan.

- Heeft pijnstillers gekregen. Maar gebruikt ze niet.

\section{INSPECTIE}

INSPECTIE IN STAND, GEWOONTEHOUDING:

- algemene indruk:

- nomaal postuur.

- atletisch gebouwd

- uitpuilend abdomen

- kyfotische thoracale wervelkolom

- lokale inspectie:

elke lichaamsregio wordt beoordeeld op: vorm, relief, afmeting, stand en kleur

- spina iliaca posterior superior even hoog

- christaranden even hoog

- scoliose lumbaal convex naar links, top \pm lumbaal 3

- scoliose thoracaal convex naar rechts, top \pm thoracaal 8

- de spina scapula is rechts beter zichtbaar dan links

- de nek/schouderlijn is rechts korter

- okselcontact is rechts langer

- spina iliaca anterior superior even hoog

- pars acromialis claviculae staat rechts hoger

- schoudertop is links ronder dan rechts

- de transversale as door de heupgewrichten staat voor de lijn: centrum schoudergewricht/centrum enkelgewricht

- diepe cerwicale lordose

- naar voren geschoven hoofd

INSPECTIE IN STAND, GECORRIGEERDE HOUDING:

- lokale inspectie:

- de scolioses lumbaal en thoracaal zijn niet meer aanwezig

- de cervicale lordose is nu afgevlakt

- de thoracale kyfose blijft aanwezig

INSPECTIE TIJDENS BEWEGEN:

- Werpen van een bal:

De maximale uithaalbeweging (achterzwaaifase) is pijnlijk aan de ventrale zijde van het schoudergewricht. De acceleratiefase kan gestart worden maar moet worden afgebroken vanwege pijn in de regio deltoidea. 


\section{ONDERZOEK EN TESTEN}

\section{ONDERZOEK CER VICALE WER VELKOLOM:}

\section{Actief bewegingsonderzoek:}

Beoordeeld worden: bewegingsverloop, uitslag en pijn

- Anteflexie: ca. $10^{\circ}$ graden beperkt ten opzichte van de passieve bewegingsmogelijkheid. Bij het bereiken van de eindgrens treedt pijn op. Pijn is goed te verdragen en wordt mid-cervicaal aangegeven.

- Retroflexie: vindt voomamelijk hoog cervicaal plaats.

- Rotaties: met de thoracale wervelkolom in gewoontehouding (sterk kyfotisch) is geen meebewegen zichtbaar van de hoog thoracale processus spinosi. Is de thoracale wervelkolom maximaal gestrekt is meebewegen zichtbaar.

- Lateroflexie rechts: g.b.

- Lateroflexie links ca. $10^{\circ}$ beperkt t.o.v. de actieve lateroflexie naar rechts. $\mathrm{Er}$ is geen pijn.

\section{Passief bewegingsonderzoek:}

\section{Beoordeeld worden: pijn, uitslag en eindgevoel}

- Anteflexie: ca. $10^{\circ}$ verder t.o.v. de actieve bewegingsmogelijkheid. Het eindgevoel is normaal. Bij het testen van het eindgevoel treedt pijn op. Pijn is scherper t.o.v. do actieve beweging, blijft goed te verdragen en wordt mid-cervicaal aangegeven.

- Retroflexie: Het eindgevoel is normaal. Bij het testen van het eindgevoel treedt pijn op. $\mathrm{Pijn}$ is minder scherp t.o.v. de passieve anteflexie beweging.

- Rotaties: g.b.

- Lateroflexie rechts: g.b.

- Lateroflexie links: ca. $5^{\circ}$ beperkt t.o.v. de passieve lateroflexie naar rechts. Het eindgevoel is stug verend. Bij het bereiken van de eindgrens wordt een "trekkende" pijn aangegeven ter hoogte van de rechter nek-schouderlijn.

- Tractie: g.b.

- Compressie met cervicale wervelkolom in flexie: Er treedt pijn op, die goed verdraagbaar is en mid-cervicaal wordt gelokaliseerd. Gaat de compressie over in en tractie dan verdwijnt de pijn onmiddellijk.

- Compressies met hoofd in middenpositie en extensie: g.b.

Isometrische weerstandstesten:

Beoordeeld worden: kracht en pijn

- Weerstanden: g.b.

- Weerstandentesten: g.b. 


\section{ONDERZOEK ARTICULATTO STERNO-CLAVICULARIS: g.b.}

\section{ONDERZOEK ARTICULATIO ACROMIO-CLAVICULARIS: g.b.}

\section{ONDERZOEK ARTICULATIO HUMERI:}

\section{Actief bewegingsonderzoek:}

\section{- Anteflexie gleno-humeraal + elevatie scapulo-thoracaal:}

Bij anvang wan de beweging staat het scapula in elevatie t.o.v. links. De laterorotatie is gedurende het hele bewegingstraject groter dan links. De beweging is ca. $5^{\circ}$ beperkt t.o.v. links. Bij het bereiken van de eindgrens wordt pijn aangegewen "diep" in de schouder. De pijn is goed te verdragen.

- Abductie gleno-humeraal + elevatie scapulo-thoracaal:

De beweging gat gepaard met een gelijktijdige elevatie en laterorotatie van het scapula. Als de hoek humerus/verticaal ca, $80^{\circ}$ is dan wil de patiënt de beweging stoppen. Er treedt dau een scherpe, stekende pijn op in de regio deltoidea en de laterale zijde van de bovenarm. Op aandringen van de onderzoeker kan de patiënt de beweging afmaken. Als de hoek humerus/verticaal $\mathrm{ca}_{\mathrm{a}} 110^{\circ}$ is wordt de pijn minder. Bij maximale abductie/elevatie neemt de pijn weer toe in de regio deltoidea en de laterale zijde van de bowenarm. Na het beëindigen van de beweging gaat de patiënt licht woorover staan en schudt even met zijn hand.

De beweging is ca. $10^{\circ}$ beperkt t.o.v. links.

- Adductie: g.b.

- Retroflexie: Beiderzijds uitgevoerd met een toegenomen thoracale flexie.

- Endorotatie: g.b.

- Exorotatie: ca. $15^{\circ}$ beperkt t.o.v. links. Eit treedt pijn op aan de ventrale zijde van de schouder. Caudaal t.o.v. het articulatio acromiomclavicularis.

Passief bewegingsonderzoek:

- Anteflexie gleno-humeraal + elevatie scapulo-thoracaal: De beweging is beperkt, maar minder t.o.v. de actieve anteflexie. Het eindgevoel is rechts harder dan links. Bij het testen van het eindgevoel treedt pijn op die door de patiënt wordt aangegeven ter hoogte van het acromio-claviculair gewricht.

- Abductie gleno-humeraal + elevatie scapulo-thoracaal:

De humerale abductie is ca. $15^{\circ}$ beperkt t.o.w. links. Het eindgevoel van de humerale abductie is rechts stugger dan links. Er treedt pijn op in de regio deltoidea re. de pijn is minder scherp t.o.v. de actieve beweging. De humerale abductie + elewatie scapulo-thoracal is ca. $5^{\circ}$ beperkt. Het testen van het eindgevoel van deze beweging laat de patiënt niet toe. Voor het bereiken van de eindgrens treedt pijn op in de regio deltoidea en de laterale zijde van de bovenarm.

- Adductie: g.b.

- Retroflexie: g.b.

- Endorotatie: ca. $5^{\circ}$ beperkt rechts t.o.v. links. Eindgevoel rechts stugger dan links. Er treedt tijdens het beoordelen van het eindgevoel pijn op aan de ventrale zijde van de schouder.

- Exorotatie: ca. $10^{\circ}$ beperkt rechts t.o.v. links. Eindgevoel rechts stugger dan links. Voordat het eindgevoell beoordeeld kan worden treedt er pijn op aan de ventrale zijde van het schoudergewricht. De pijn is scherp en net te verdragen. Na deze test zakt de pijn langzam binnen enige seconden. 
- Tractie: Eindgevoel rechts stugger dan links.

- Compressie: g.b.

- Translatie in dorso-lateralie richting: g.b.

- Translatie in ventro-mediale richting: Beperkte uitslag rechts t.o.v. links. Eindgewoel rechts stugger. Geen pijn.

- Translatie in caudale richting: g.b.

Isometrische weerstandstesten:

- Abductie in anatomische o-stand: veminderde kracht t.o.w. links. Er wondt een scherpe stekende pijn aangegeven in de regio deltoïdea en laterale zijde van de bovenam. Na ontspannen verdwijnt de pijn geleidelijk.

- Abductie vanuit $90^{\circ}$ glenohumerale abductie: verminderde kracht t.o.w. links. Er wordt tijdens de contractie mindex pijn aangegeven als t.o.v. abductie vanuit de anatomische o-stand.

\section{ONDERZOEK ARTICULATIO CUBITI:}

Actief bewegingsonderzoek: $\mathrm{g} . \mathrm{b}$.

Passief bewegingsonderzoek: g.b.

Isometrische weerstandstesten: $g . b$.

\section{TESTEN VAN DE CERVICALE WERVELKOLOM EN SCHOUDERGORDEL}

- Patiënt:

Fysiotherapeut:

Bevindingen:

- Patiënt:

Fysiotherapeut:

Bevindingen:

- Patiënt:

Fysiotherapeut:

Bevindingen:

- Patiënt:

Fysiotherapeut:

Bevindingen:
Ruglig $_{\text {, ogen open. }}$

Brengt nek in maximale extensie en rotatie gedurende $40-50$ seconden.

G..b.

Zit.

Brengt hoofd passief in lateroflexie naar de heterolaterale zijde. De te onderzoeken arm in retroflexie en abductie, elleboog in extensie en pronatie, pols en vingers in flexie. G.b.

Stand, lateroflexie weg van de te onderzoeken zijde. Schoudergordel in depressie en retractie en ademt diep in. Palpatie radialispols.

G.b.

Zit.

Brengt de te onderzoeken arm in elevatie en hyperabductie. Palpeert radialispols.

Radialispols blijft palpabel. Test moet rechts gestaakt worden. Er wordt een scherpe pijn aangegeven aan de ventralle zijde van de schouder, caudaal t.o.v. het articulatio acromio-clavicularis. 
- Patient:

Fysiotherapeut:

Bevindingen:
Zit, woert isometrische contractie uit; abductie humerus wanuit de o-stand

Geeft weerstand aan de humerus en handhaaft gedurende de contractie, een tractie glenohumeraal

Pijn laterale zijde bovenam, maximaal in de regio deltoidea. Pijn is scherp stekend en verdwijnt geleidelijk na ontspanning.

\section{METINGEN}

\section{SPIERKRACHTMETINGEN:}

- Indien bij een spierkrachtmeting gesproken wordt over stabilisatie dan is er sprake van een isometrische contractie.

Worden er alleen anatomische bewegingsrichtingen vermeld dan is er sprake van een isotonische contractie in de genoemde bewegingsrichting(en).

Normering:

5 - volledige beweging c.q. stabilisatie is mogelijk tegen de richting van de zwaartekracht met flinke weerstand.

4 - als 5 , met lichte weerstand.

3 - volledige beweging is mogelijk tegen de zwaartekracht in.

2 - volledige beweging is mogelijk in een horizontaal vlak.

1 -er is voelbare en/of zichtbare contractie, beweging komt niet tot stand.

0 -er wordt geen contractie waargenomen.

- Stabilisatie van het scapula in abductie en laterorotatie: 5 .

- Elevatie scapula, extensie en rotatie van hoofd en nek in de richting van de geëleveerde schouder, met het gezicht geroteerd in de tegengestelde richting: 5.

- Stabilisatie van het scapula in adductie en laterorotatie. Humerus 90 gr. geabduceerd en geëxoroteerd: 5, en pijn ter hoogte van de tuberositas deltoïdea. Pijn is goed te verdragen, maar moeilijk aan te geven. Bij ontspannen verdwijnt de pijn.

- Exorotatie van de humerus met elleboog $90 \mathrm{gr}$. gebogen, vanuit de anatomische o-stand: 5. En aan het eind van de beweging is er sprake van een scherpe pijn aan de vertrale zijde van de schouder.

- Endorotatie van de humerus met elleboog $90^{\circ}$ gebogen, vanuit de anatomische o-stand: 5.

- Extensie en addluctie van de humerus, vanuit een geëndoroteerde positie van de humerus. De hand van de onderzochte zijde nust op de dorsale rand van de christa iliaca: 5 .

- Adductie en extensie humerus met gestrekte elleboog en geëndoroteerde arm: 5 .

- Adductie humerus, vanuit $90^{\circ}$ anteflexie en lichte endorotatie en gestrekte elleboog: 5 .

- Abductie humerus vanuit de anatomische o-stand: 3-4, er is bereidheid tot contractie, bij $80^{\circ}$ abductie wordt de beweging gestaakt. De pijn is te hevig. De pijn wordt gevoeld over de gehele laterale zijde van de bovenarm. Na beëindigen contractie verdwijnt de pijn.

- Extensie elleboog vanuit anatomische o-stand schouder en o-stand elleboog: 5, en lichte pijn ter hoogte van de laterale regio van de schoudertop. Na beëindigen contractie verdwijnt pijn.

- Flexie elleboog en supinatie elleboog vanuit anatomische o-stand van de schouder en geèxtendeerde elleboog: 5. 


\section{SPIERLENGTEMETINGEN:}

Gehanteerde norm staat bij ellke lengtemeting vermeld

- Patiënt:

Fysiotherapeut:

Uitslag lateroflexie:

- Patiënt:

Fysiotherapeut:

Uitslag lateroflexie:

- Patiënt:

Fysiotherapeut:

Uitslag:

- Patiënt:

Fysiotherapeut:

Uitslag:

- Patiënt:

Fysiotherapeut:

Uitslag: ruglig, armen langs romp.

fixeert schouder en voert een cervicale heterolaterale lateroflexie uit.

- naar rechts $\pm 50^{\circ}$

- naar links $\pm 40^{\circ}$

- nom $\pm 45^{\circ}$

nuglig, met de hand van de te onderzoeken zijde ter hoogte van de cervicothoracale overgang.

fixeert schouder en voert een heterolaterale lateroflexie uit.

- naar rechts $\pm 60^{\circ}$

- naar links kan niet getest worden, in de beschreven uitgangshouding. De rechterschouder is dan te pijnlijk

ruglig.

fixeert thorax en brengt arm geêxoroteerd in $135^{\circ}$ abductie.

- links norm bereikt

- rechts niet uitvoerbaar vanwege de pijn die ontstaat bij het abduceren humerus.

- norm: arm moet in $135^{\circ}$ abductie het horziontale wlak bereiken.

zijlig.

retroflecteert schouder, extendeert en proneert elleboog.

- rechts norm bereikt. Aan het eind van de beweging wordt er pijn aangegeven aan de ventrale zijde van de schouder.

- links: norm bereikt

- nom: maximale retroflexie schouder en maximale extensie elleboog moet bereikt worden.

zijlig.

anteflecteert schouder, flecteert en supineert elleboog.

- rechts norm bereikt

- links norm bereikt

- norm: maximale anteflexie schouder en maximale flexie elleboog moet bereikt worden. 


\section{PALPATIE}

Per regio wondt een indruk werkjegen over: huid en onderhuids bindweefsel, gewrichtskapsels en ligamenten, botstructuren, spier- en peesstructuren, zenuwen en bloedvaten.

\section{Palpatie in rust:}

- Regio vertebralis en cervicalis:

Op processus spinosus C3 na zijn alle doomuitsteeksels goed palpabel. Bij het geven van een impuls naar ventraal geeft C5 pijn paravertebraal.

De paravertebrale musculatuur ter hoogte van $\mathrm{C} 4 \mathrm{t} / \mathrm{m} \mathrm{C} 7$ is rechts drukgevoeliger en verminderd indrukbaar.

- Regio suprascapularis:

De musculatuur die de contour van de rechter nek/schouderlijn bepaalt is drukgevoeliger en verninderd indrukbaar.

- Art. stemoclaviculairs: g.b.

- Art acromio-clavicularis:

Gewrichtskapsel is gezwollen t.o.v. rechts. En pijnlijk bij dwarse palpatie.

- Regio deltoidea:

Tuberculum majus humeri rechts is pijnlijker dan links. Tuberculum minus humeri rechts is pijnlijk, minder pijnlijk als het tuberculum majus humeri.

Pees ter hoogte van het bovenste facet van het tuberculum majus humeri rechts is drukpijnlijk. Pijn is het hevigst ter hoogte van de palpatie, maar wordt gevoeld in de hele regio deltoildea. Bij vergelijking wordt rechts een zachtere weerstand aangetroffen. De pees ter hoogte van het middelste facet van het tuberculum majus humeri is drukpijnlijker dan links. De weerstand is links en rechts gelijk. De pees ter hoogte van het tuberculum minus is beiderzijds lokaal druk-pijnlijk. De pees ter hoogte van de tuberositas deltoidea is rechts even drukgevoelig als links. Geen pijn.

Musculatuur regüo delltoïdea: g.b.

\section{Palpatie tijdens bewegen:}

- Bij herhaalde abductie zijn beiderzijds crepitaties van het art. acromio-clavicularis voelbaar. Rechts meer dan links. Er is geen pijn. 


\section{Kennisitems bij casus schouderklacht}

- Bij palpatie van het bovenste facet van het tuberculum majus humeri voel je de insertie van de $\mathrm{m}$. infraspinatus. (onjuist)

- Passief doorbewegen van de arm in maximale elevatie naar mediaal comprimeert de spierpees overgang van de $\mathrm{m}$. supraspinatus tegen het tuberculum supraglenoïdale. (onjuist)

- Een painful-arc tussen $80^{\circ}-120^{\circ}$ kan duiden op een subacromiale compressie van het oppervlakkige teno-periostale deel van de m. supraspinatus. (juist)

- Een painful-arc tussen $80^{\circ}-120^{\circ}$ van de $\mathrm{m}$. supraspinatus valt niet weg bij het passief bewegen van de humerus onder tractie. (onjuist)

- De m. teres minor hecht aan op het middelste facet van het tuberculum majus humeri. (onjuist)

- Een tendinitis van de $\mathrm{m}$. teres minor kan painful-arc verootzaken. (juist)

- Het kapsulaire patroon wan de schouder kenmerkt zich door de pijnlijkheid wan 3 bewegingsrichtingen. (onjuist)

- Pijn bij compressie van de cervicale wervelkolom in lichte flexie duidt op een aandoening van de facetgewricten. (onjuist)

- Bij doorgevoerde armelevatie draaien de processus spinosi C7-Th5 naar homolateraal. (onjuist)

- Een rotatie beperking cervico-thoracaal veroorzaakt een bewegingsbeperking van de armelevatie en een compressie van de clavicula tegen de le rib. (juist)

- Glenohumerale abductie vereist gelijktijdige abductie en craniale translatie van het caput humeri. (onjuist)

- Bij een bovenhandse werpbeweging wordt na de uithaalbeweging en voor de zwaaifase de hume-ruskop gestabiliseerd door de: $\mathrm{m}$. latisimus dorsi, $\mathrm{m}$. pectoralis en m.deltiideus. (onjuist)

- De kracht van de isometrische weerstandstest exorotatie schouder is verminderd bij een uitval van de $n$. suprascapularis. (juist)

- Bij het voorwaarts heffen van de arm tot $90^{\circ}$ vindt in de art. acromioclavicularis geen laterorotatie plaats van de scapula. (onjuist) 


\section{Bijlage 2: Probleemtoets en bijbehorende kennisitems}

\section{Instructie probleemtoets}

In de volgende 15 situaties worden problemen gepresenteerd uit het fysiotherapeutisch diagnostisch domein.

Elk probleem begint met een opdracht. Lees deze goed. Deze opdrachten zijn niet altija identiek.

Geef aan de hand van de gegeven informatie een zo exact mogelijke oplossing. Enkele woorden of een zin is voldoende.

Schrijf de oplossing bij het overeenkomstige nummer op het antwoord formulier. 


\section{Probleem I}

Opdracht: Geef aan waarop U de wolgende onderzoekshandeling wilt richten in het kader van de diagnosestelling.

De heer P. van de W. is 28 jaar en doet aan atletiek. De laatste weken is hij intensief bezig geweest met speerwerpen. Hij heeft sinds 2 weken last van zijn schouder. In het begin alleen na de training; maar m ook tijdens het werpen. Hij kan geen trauma aangeven.

De pijn is gelokaliseerd aan de voorzijde van de schouder en straalt iets uit naar de bovenarm. $\mathrm{Bij}$ het actief bewegingsonderzoek wan de schouder zijn er geen bijzonderheden. Bij het passief bewegingsonderzoek is het testen van het eindgevoel wan de exorotatie licht pijnlijk aan de voorzijde van de schouder. Er is geen witstraling.

Laat de onderzoeker een abductie uitwoeren onder handhaving van een maximale glenohumerale exorotatie dan geeft de patiënt pijn aan tussen $120^{\circ}$ en $145^{\circ}$ abductie.

De teruggaande beweging is niet pijnlijk. En bij herhaling van de test is de pijn niet altijd te prowoceren.

\section{Kennisitems}

- Een painful-arc gedurende de abductie/elevatie van de humerus met handhaving van maximale gleno-humerale exorotatie kan veroorzaakt worden door het proximale deel van de insertie van de m. subscapularis en het tuberculum minus. (juist)

- Als bij het herhalen van de beweging een aanvankelijk aanwezige painful-arc niet meer optreedt, dan heeft de painful-arc geen diagnostische waarde. (onjuist)

\section{Probleem 2}

Opdracht: Geef aan de hand van onderstaande gegevens de bewegingsrichting(en) die als traumatisch moment hebben ingewerkt op de knie.

Door middel van een passief bewegingsonderzoek van de knie verkrijgt u de volgende gegevens:

- flexie: $\quad 30^{\circ}$ beperkt en pijnijijk

- extensie: $\quad 5^{\circ}$ beperkt en pijnlijk

- exorotatie: $5^{\text {w }}$ vergroot en pijnlijk

- endorotatie: g.b.

Specifieke testen:

- valgus (abductie) van het onderbeen: met de knie in $0^{\circ}$ niet uitwoerbaar; met de knie $30^{\circ}$ vergroot en pijnlijk.

- varus (adductie) van het onderbeen: met de knie in $0^{\circ}$ niet uitwoerbaar; met de knie in $30^{\circ} \mathrm{g} \cdot \mathrm{b}$.

- schuifladetest naar voren in neutrale stand: vergroot $=+$, en niet pijnlijk

- schuifladetest naar voren in exorotatie ${ }_{*}$ vergroot $=++$, en niet pijnlijk

- schuifladetest naar voren in endorotatie: g.b.

- schuifladetest naar achteren in alle standen g.b. 
- fluctuatietest: positief

- ballotement van de patella: positief

- meniscustest volgens Mc Murray niet uitwoerbaar

- knie, van de op de buik liggende patiënt, $90^{\circ}$ gebogen. Onder handhaving van compressie wordt het onderbeen geroteerd. Endorotatie g.b.

Exorotatie; pijn mediaal

\section{Kennisitems}

- Een zogenaamd valgus-llexie-exorotatie trauma van de knie kan een scheuring van de voorste kruisband veroorzaken en een anteromediale instabiliteit tot gevolg hebben. (juist)

- Een antero-mediale instabiliteit van de knie is aanwezig bij een schuiflade naar voren in exorotatie. Deze kan veroorzaakt worden door het postero-laterale kapsel apparaat. (onjuist)

\section{Probleem 3}

Opdracht: Geef aan de hand van onderstaande gegevens de belangrijkste waarschijnlijk heidsdiagnose.

Een huisvrouw klaagt over pijn aan de radiale zijde van de pols.

De pijn straalt uit tot het topje van de duim en vanuit de pols ook naar proximaal tot halverwege de onderarm.

Bij functie-onderzoek zijn de actieve en passieve ulnairabductie aan de radiale zijde van de pols pijniijk. De passieve ulnairabductie is pijnlijker dan de actieve.

Tracties en translaties g.b.

De volgende isotonische weerstandstesten zijn pijnlijk:

- weerstand tegen gelijktijdige abductie en extensie van het carpometacarpaal gewricht I.

- weerstand tegen een gelijktijdige abductie en extensie wan het carpometacarpaal gewricht $I$ in combinatie met extensie van het metacarpophalangeaal gewricht I.

Laat men de patiënte een vuist maken waarbij ze haar duim met de vingers omsluit en vervolgens de in lichte dorsaalflexie gehouden vuist naar ulnairdeviatie brengt, dan wordt zeer heftige pijn aangegeven aan de radiale zijde van de carpus.

Bij palpatie is het distale deel van de radius zeer drukpijnlijk.

\section{Kennistems}

- Door weerstand te geven aan een gelijktijdige abductie en extensie van het carpometacarpaal gewricht I test je de m. abductor pollicis longus. (juist)

- Door weerstand te geven aan een gelijktijdige abductie en extensie van het carpophalangeaal gewricht $I$ in combinatie met extensie van het meta carpophalangeaal gewricht I test je de m. extensor pollicis brevis. (juist) 


\section{Probleem 4}

Opdracht: Geef aan de hand varn onderstaande gegevens de belangrijkste waarschijnlijkheidsdiagnose.

Een 56-jarige man is 8 weken geleden wan een paard gevallen. Daarbij heeft hij links een trimalleolaire tibia- en fibulafractuur opgelopen. Deze fractuur is chirurgisch behandeld. De gipsfase heeft 6 weken geduurd. De fractuur is goed geconsolideerd. Momenteel mag hij het been belasten tot $\pm 20 \mathrm{~kg}$. Sinds het verwijderen van het gips klaagt de patient over een brandende diffuze pijn in het onderbeen en de voet. Distaal is de pijn het hevigst. De pijn neemt in de loop wan de dag toe. Zwelling van voet en onderbeen neemt dan toe.

Bij inspectie blijkt de kuit sterk in omvang afgenomen. Het distale deel van het onderbeen, de enkel, de voetrug en de tenen zijn gezwollen. De huid is dun glanzend, roodachtig en de haargroei is toegenomen. De voet voelt warm en vochtig aan. Het aanraken wan de voet wordt als pijnlijk ervaren. Stilstaan gedurende de inspectie doet pijn en tintelingen nemen toe.

Alle bewegingen van de enkel zijn actief en passief beperkt en voelen stijf aan. De voet onbelast actief bewegen is niet pijnlijk. Hoog leggen van de voet vermindert pijn en zwelling.

De plantairflexoren zijn verkort.

\section{Kennistems}

- De door Südeck beschreven posttraumatische dystrofie is een pijnlijke osteoporose en kan voorkomen na een minimaal trauma. (juist)

- Hyperaemie, hyperhydrosis en versterkte haargroei wijzen op een neurovegetatieve dysregulatie van circulatie en trofiek. (juist)

\section{Probleem 5}

Opdracht: Geef aan waarop u de volgende onderzoekshandeling wilt richten in het kader van de behandelopdracht wan de arts.

Een man van 42 jaar is in het ziekenhuis opgenomen met een ontregelde bloedsuikerspiegel. Hij lijdt aan een juveniele diabetes mellitus. De patiënt heeft de laatste tijd moeite met lopen m.n. traplopen. Hij durft niet goed meer te lopen omdat hij de laatste tijd geregeld "door zijn linker-enkel gatat". Hij heeft geen pijn.

Behandelopdracht arts: spierversterking + stabilisatietraining enkels bij charcotgewricht.

Via het fysiotherapeutisch onderzoek krijgt u de volgende gegevens:

- X-foto's: art. tibiotarsale beiderzijis arthrotisch, links meer dan rechts.

- Bij inspectie in stand staan beide voeten in versterkte inversie.

Links meer dan rechts.

- Actieve stabiliteit is beiderzijds gestoord. Links meer dan rechts.

- Linker-enkel is rond beide malleoli en voetrug gezwollen. Voet voelt warmer aan dan rechits. $\mathrm{Er}$ is geen roodheid.

- Mobiliteit bovenste spronggewricht is links meer beperkt dan rechts.

De plantairflexie is meer beperkt dan de dorsalflexie zowel actief als passief. 
- De passieve inversie mogelijkheid is links vergroot.

- Schuiflade-test naar voren en naar achteren is links vergroot.

- Spierkracht links: dorsaalflexoren 3, plantairflexoren 4 rechts: dorsaalflexoren 4 , plantairflexoren 5 .

\section{Kennisitems}

- Een charcot-gewricht is een degeneratieve gewrichtsaandoening, optredend in het verloop van een sensorische neuropathie. (juist)

- De combinatie van emstige arthrose, habituele luxaties en geen pijn duidt op exteroceptieve en proprioceptieve afwijkingen. (onjuist)

\section{Probleem 6}

Opdracht: Geef aan waarop u de volgende onderzoekshandeling wilt richten in het kader van de diagnosestelling.

Een 34-jarige vrouw heeft een week geleden gedurende 2 dagen een softbaltoemooi gespeeld. De dagen daama had zij een heftige pijn aan de ventrale zijde van de elleboog. Deze pijn straalde uit tot bijna aan

de pols. Er is geen traumatisch moment bekend.

$\mathrm{Zij}$ heeft al jaren last van de elleboog. Maar dat is een periodiek zeurende pijn rond de epicondylus lateralis. Volgens de patiënte is dit een restverschijnsel van een whip-lash trauma 5 jaar geleden. Voor deze klachten is zij behandeld door een manueel therapeut. $\mathrm{Zij}$ vraagt zich nu af of door het softballen de nek weer is "wakker" gemaakt. Zij heeft de afgelopen week geen last van de nek gehad. Alleen stijf de dag na het toer-nooi. Bij het actief bewegingsonderzoek van de elleboog is alleen de pronatie pijnlijk. Bij het passief bewegingsonderzoek is de pronatie pijnlijk bij het testen van thet eindgevoel. Ook de passieve extensie is bij het testen van het eindgevoel pijnlijk aan de ventrale zijde van de elleboog. Er zijn geen bewegingsbeperkingen.

\section{Kennistems}

- Pijn bij passieve pronatie van de elleboog kan veroorzaakt worden doordat de gezwollen peesinsertie op de tuberositas radii tegen de ulna ankomt. (juist)

- Een tendinitis van de $\mathrm{m}$. biceps brachii ter hoogte van de teno-ossale insertie veroorzaakt pijn bij passieve extensie van de elleboog ten gevolge van rek. (juist)

\section{Probleem 7}

Opdracht: Geef aan de hand van onderstaande gegevens de belangrijkste waarschijnlijkheidsdiagnose.

Een verpleegster van 20 jaar voelde tijdens het tillen van een patiënt een plotselinge schok in haar rug laag lumbaal. Zij voelde iets knappen. Aangezien de pijn niet erg was, bleef zij aan het werk: wel voelde zij een pijn in de gehele lendestreek die zich soms uitbreidde 
nuar billen en bovenbenen. De pijn verergert door zitten in een stoel, bij vermoeidheid en voor de menstruatie. Een foetale houding tijdens de slaap verergert de pijn. Zij staat dan thet moeite op en gaat wat lopen.

De knagende pijn is momenteel constant en dringt zich op als zij iets moet oppakken. Het is nu zo dat ze ongeveer alle dagelijkse bezigheden maar een kwartier kan volhouden.

Bij inspectie is ex een achterovergekanteld bekken en een toegenomen lumbale lordose.

De karakteristieke pijn treedt op als men de patiènte enige tijd in extensie laat staan. Bij zowel flecteren als extenderen is er een pijnlijk traject van 30 tot $45^{\circ}$ waarin zij lijkt uit te wijken en te aarzelen. Gedurende dit traject grijpt de patiënte voor steun naar haar bovenbenen. De wervelkolom is hypermobiel op alle niveaus en in alle richtingen.

$\mathrm{Er}$ is geen distale pijn in de benen, er zijn geen neurologische verschijnselen of uitval. Op de röntgenfoto met de vrouw in stand: is geen afwijking te zien.

\section{Kennisitems}

- Bij een spondylolisthesis neemt de lumbale lordose toe. De patiënt kan dit compenseren door het bekken achterover te kantelen en de knieën te flecteren. (juist)

- Laag-lumbale ligamentaire laesies kunnen primair een radiculair syndroom veroorzaken. (onjuist)

\section{Probleem 8}

Opdracht: Geef aan waarop u de volgende onderzoekshandeling wilt richten in het kader van de diagnosestelling.

Een wrouw van 45 jaar is 3 weken geleden gevallen met de fiets. Ze werd verdacht van een sleutelbeenfractuur links. De x-foto's waren negatief. Sindsdien heeft ze pijn op de schoudertop en kan ze haar arm niet maximaal eleveren. Haar belangrijkste klacht is dat ze 's nachts wakker wordt met pijnlijke tintelingen in alle vingers van de linkerhand. 's Ochtends heeft ze het eerste half uur een verminderde knijpkracht links. Voor het trauma had ze ook dergelijke klachten maar mindler frequent en niet zo hevig.

Uit het functie-onderzoek blijkt het volgende:

- Cervicale wervelkolom: g.b.

- Actief bewegingsonderzoek linkerschouder: Abductie humerus (elevatie schouder) tot de horizontaal g.b. Boven de horizontaal wordt de beweging met een thoracale lateroflexie gecompenseerd.

- Passief bewegingsonderzoek linkerschouder: Alle bewegingen rond de anatomische assen zijn bij het testen van het eindgevoel pijnlijk.

De horizontale adductie is het meest pijnlijk en beperkt.

- Tracties en translatie art. acromio-clavicularis links: De handvattingen zijn gevoelig en pijnlijk. Maar het gewrichtsspel is gelijk aan rechts.

- Tracties en translaties art. stemo-clavicularis links: Het gewrichtsspel is vergroot en pijnlijk in alle richtingen met name in dorsale en caudo-laterale richting.

\section{Kennisitems}

- Een luxatie van het art. sterno-clavicularis naar retrosternaal kan pijn en verlammingsverschijnselen in de hand veroorzaken. (juist) 
- In de costo-claviculaire ruimte kunnen de volgende structuren gecomprimeerd worden: $*$ : subclavia, lymfevaten, a. subclavia, n. phrenicus, plexus brachialis an de sympatische vezels. (onjuist)

\section{Probleem 9}

Opdracht: Geef op basis van onderstaande gegevens de belangrijkste waarschijnlijkheids * diagnose.

Een man wan 52 jaar wordt verwezen met de diagnose "cervicaal. syndroon". Hij heeft al jaren last van een ochtendstijve pijnlijke nek. Hij is auto-monteur. Als hij een tijdje onder een auto heeft gewerkt heeft hij last van hoofdpijn en duizeligheid. Staat hij weer normaal rechtop dan verdwijnen de klachten weer.

Gegevens functie-onderzoek:

- Actief bewegingsonderzoeker cervicale wervelkolom:

Behalve de flexie zijn alle bewegingen niet pijnlijk beperkt.

- Passief bewegingsonderzoek cervicale wervelkolom:

De extensie is het meest beperkt, niet pijnlijk. Patiènt geeft angst aan voor eventuele duizeligheid bij verder doorvoeren extensie. Er is een leeg eindgevoel. Vervolgens zijn de lateroflexie rechts en de rotatie links het meest beperkt en pijnlijk. De pijn wordt paravertebraal rechts aangegeven. Lateroflexie links en rotatie rechts zj.jn het minst beperkt en niet pijnlijk. Het eindgevoel is in alle richtingen verhard.

- Compressietest:

Wordt er compressie gegeven met nek in lateroflexie rechts dan is er pijn paravertebraal rechts. Compressie in andere nekstanden g.b.

- Tractietest: g.b.

- Functie-onderzoek schouders: g.b.

- Sensibiliteitsmetingen: g.b.

- Spierkracht metingen: g.b.

- Testbevindingen:

Wordt het hoofd gedurende ruglig in dorsaalflexie en maximale rotatie links gebracht dan ontstaat er na 50 seconden een gevoel wan misselijkheid en duizeligheid. Patiènt wordt bleek en begint te transpireren. Bij rotatie naar rechts $\mathrm{g} . \mathrm{b}$.

- Wordt er een kortdurende axiale druk uitgeoefend met het hoofd in lichte extensie, rotatie rechts en lateroflexie rechts. Dan wordt er pijn aangegeven mid-cervicaal paravertebraal rechts. Test met rotatie links lateroflexie links $g . b$.

- X-foto's:

Versmalling tussenwervelschijven $\mathrm{C} 4$ en $\mathrm{C} 5,+$ osteofytvorming op meerdere niveaus.

\section{Kennisitems}

- Wordt tijdens de proef wan de Kleyne het hoofd in dorsaalflexie en maximale rotatie naar links gebracht dan wordt de heterolaterale a. vertebralis fysiologisch afgesloten en de homolaterale a. vertebralis getest. (juist)

- Volgens het kapsulaire patroon van de cervicale wervelkolom is de dorsaalflexie het minst en de ventraalflexie het meest beperkt. (onjuist) 


\section{Probleem 10}

Opdracht: Geef op basis wan onderstaande gegevens de belangrijkste waarschijnlijkheidsdiagnose.

Een vrouw yan 66 jaar bekend als langdurig alcoholiste woont sinds kort in een bejaardenhuis. Ze heeft ernstige leverfunctiestoomissen. En gebruikt sinds een half jaar geen alcohol meer. Ze heeft moeite met

lopen en geeft aan dat de benen niet meer willen. De huisarts vraagt de fysiotherapeut om de motoriek te beoordelen en eventueel te verbeteren.

Inspectie:

- Gaan: de vrouw loopt wijdbeens, slingerend, met onregelmatige paslengte en een breed gangspoor.

- Staan: de patiềnte probeert stil te staan met woeten $5 \mathrm{~cm}$ uitelkaar.

$\mathrm{Er}$ is sprake van bewegingsonrust en overcorrectie van musculatuur.

Worden de ogen gesloten dan neernt de bewegingsonrust niet toe.

- Vinger-neus proef: De beweging verloopt schokkerig. Naarmate het doel genaderd wordt neemt het schokken toe. Het doel wordt niet gemist.

- Hiel-knie proef: De hiel schiet de knie voorbij en kost haar veel moeite om de voet goed te plaatsen. De hiel glijdt geregeld van het onderbeen. Het observeren van de eigen handelingen verbetert het resultaat niet.

- Spreken: Zij heeft het gevoel alsof zij met een dikke tong spreekt.

Het spreektempo is vertraagd. De woorden worden in aparte lettergrepen geroepen. Het slikken is nomaal. Lallende spraak.

- Bij het geven wan een flexieweerstand van $120^{\circ}$ gebogen elleboog, schiet de hand bij plotseling loslaten door tot de schoudertop.

- Bij passief bewegen is er sprake van een hypotonus.

\section{Kennisitems}

- Bij cerebellaire aandoeningen is de proef van Romberg negatief omdat de ataxie niet verergerd wordt door oogsluiting. (juist)

- Men spreekt van een cerebellaire dysarthrie wanneer er sprake is van een gestoorde coördinatie van spraakmusculatuur waardoor de patiënt gaat struilkelen over woorden en monotoon gaat spreken. (onjuist)

\section{Probleem 11}

Opdracht: Geef aan waarop $U$ de volgende onderzoekshandeling wilt richten in het kader van de diagnosestelling.

Een vrouw wan 57 jaar wordt verwezen door de huisarts met de diagnose arthralgie linker knie. Zij klaagt over heftige pijn aan de mediale zijde van het bovenbeen, mediale zijde knie tot halverwege het onderbeen. $\mathrm{Zij}$ heeft hier het meeste last van tijdens zitten. Er is geen ochtendstijfheid of startstijfheid. De knie is volgens haar nooit gezwollen of warm. Volgens de $\mathrm{X}$-foto waren er licht arthrotische verschijnselen.

Via het onderzoek krijgt $U$ de volgende gegevens: 
Inspectie:

- zwaarlijvige, dikke vrouw

- diepe lumbale lordose

- vlakke thoracale kyfose

- diepe cervicale lordose

- coxae vara.

- genua valga

Functie-onderzoek knie:

- actief: g.b.

- passief: g.b.

- mediale instabiliteit beiderzijds, links meer dan rechts. Zowel in $0^{\circ}$ als $30^{\circ}$ flexie

- schuifladetest: g.b.

- weerstandstesten: g.b.

- Onder compressie van de patella de m. quadriceps femoris laten aanspannen geeft aan beide knieën pijn retropatellair. Links meer dan rechts.

- mobiliteit-patella: links en rechts gelijk.

- functie-onderzoek heup: $g . b$.

\section{Kennisitems}

- Het huidgebied van bovenste bilstreek, voorkant bovenbeen, mediale zijde knie en onderbeen behoort tot het dermatoom van L3. (juist)

- Aandoeningen van de knie veroorzaken lokale pijn met veel uitstraling. (onjuist)

\section{Probleem 12}

Opdracht: Geef aan de hand van onderstaande gegevens de belangrijkste waarschijnlijkheidsdiagnose.

Een man wan 32 jaar klaagt over heftige stekende pijn aan beide voeten. Hij heeft pijn gekregen na de eerste training van het seizoen. Die training bestond uit een duurloop van ca. $10 \mathrm{~km}$. Er is gelopen over asfalt en bospad. De dag daama had hij pijn onder beide voeten, rechts meer dan links. De $2 \mathrm{e}$ training heeft hij moeten staken vanwege de heftige pijn. Hij had het gevoel of er onder beidle voeten aan de laterale voetrand een knikkertje zat.

Via het onderzoek krijgt $U$ de volgende gegeven:

- Actief bewegen enkel: g.b.

- Passief bewegen enkel: Bij inversie wordt er pijn aangegeven aan de laterale voetrand ter hoogte van de metatarsus. Overige bewegingen: g.b.

- Isometrische weerstandstesten:

Pronatie wanuit maximale inversie geeft heftige pijn aan de laterale voetrand ter hoogte van de metatarsus. Links meer dan rechts.

- Palpatie: het tuberositas ossis metatarsalis $\mathrm{V}$ is zowel links als rechts zeer drukpijnlijk. 


\section{Kernisistlems}

- Wanneer er een gelijktijdige weerstand wordt gegeven tegen de plantaurflexie en pronatie van de voet, worden de m. peroneus longus en brevis belast. (juist)

- De insertie van de $\mathrm{m}$. peroneusbrevis is het tuberositas ossis metatarsalis $\mathrm{V}$. (juist)

\section{Probleem 13}

Opdracht: Geef op basis van onderstaande i.t.-curves aan wat Uw prognose is voor het herstel. Motiveer zeer kort.

In een periode van 3 maanden verkrijgt $U$ de volgende curves van de $\mathrm{m}$. brachioradialis. Deze patiënt is bekend met een neuropathie.

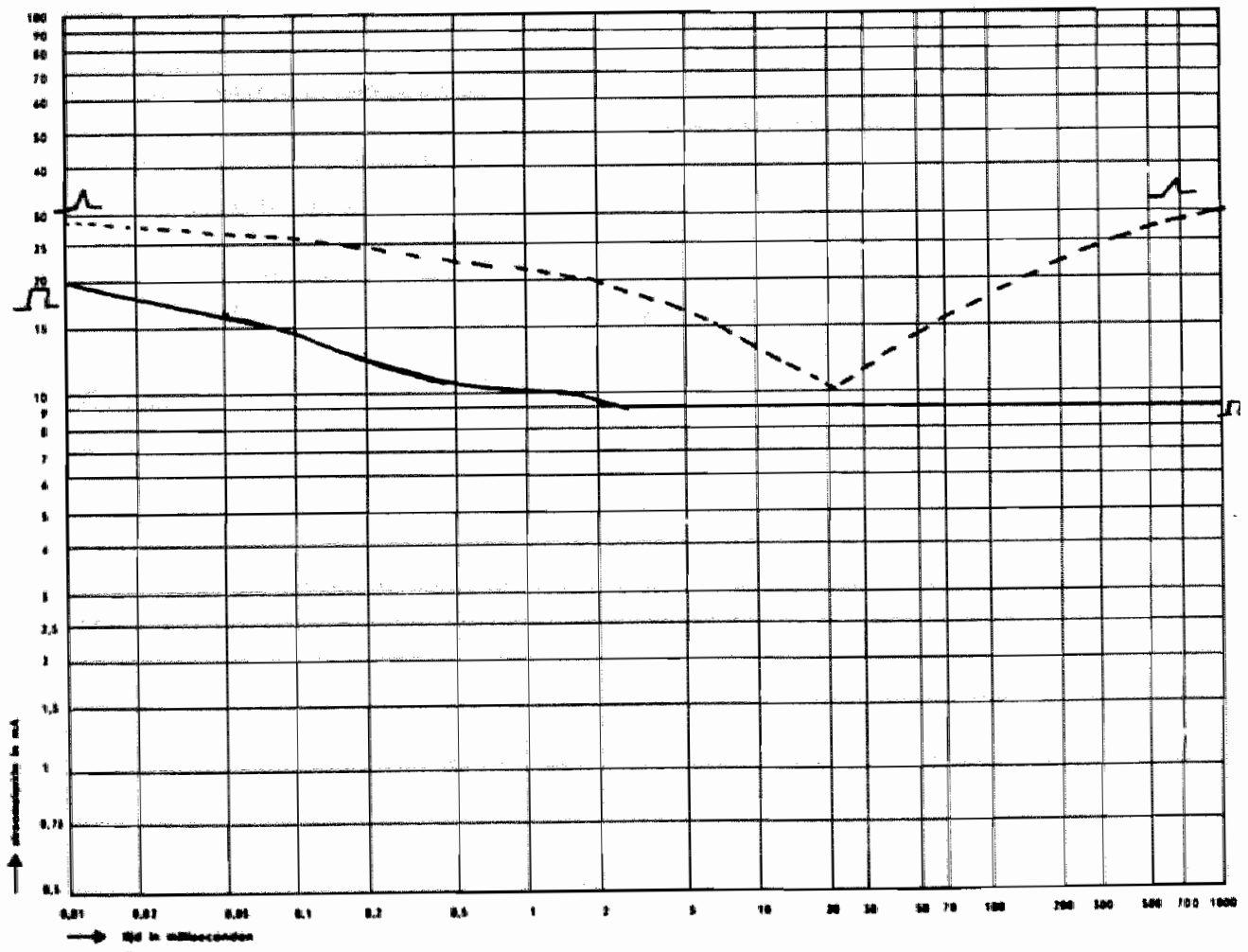



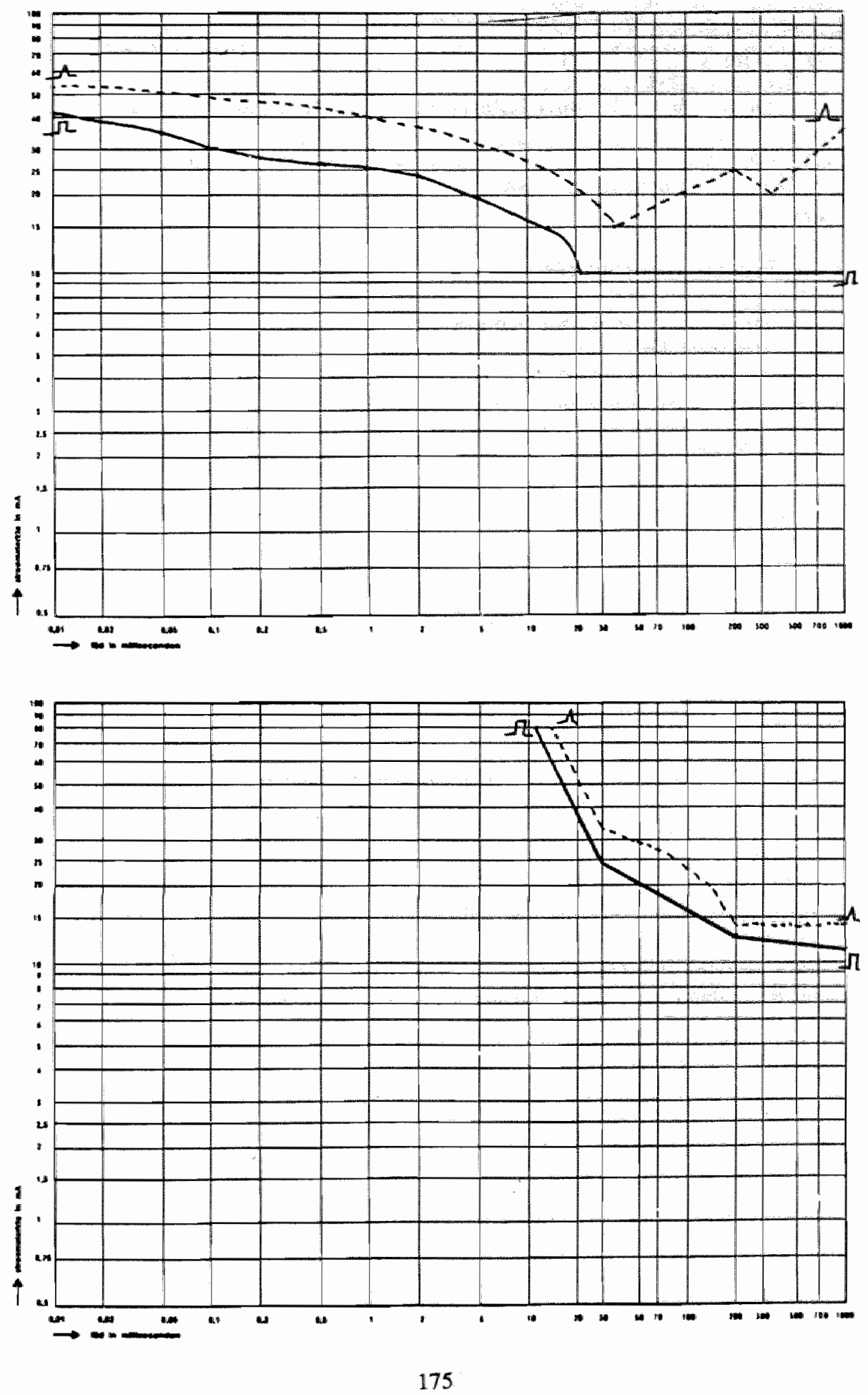


\section{Kennisitems}

- De accomodatiequotiënt zal bij een totale parese de waarde 1 nooit benaderen. (onjuist)

- De i.t.-curve zal in $90 \%$ van de gevallen bij een totale parese naar rechts boven verschoven zijn. (juist)

\section{Probleem 14}

Opdracht: Benoern de gepalpeerde structuur.

Een vrouw van 20 jaar klaagt over pijn aan de rechter-enkel tijdens het turnen. Met name de afzet bij het springen is pijnlijk.

Bij palpatie wordt het sustentaculum tali als referentiepunt gebruikt. Plantair van het sustentaculum blijkt de aanwezige ronde langwerpige structuur sterk drukpijnlijk. Deze structuur kan via palpatie nog $\pm 1,5 \mathrm{~cm}$ naar dorsaal en proximaal gevolgd worden. $\mathrm{B}_{\mathrm{ij}}$ gelijktijdige palpatie en passief bewegen van de voet zijn fijne krepitaties te voelen.

\section{Kennisitems}

- Het sustentaculum tali bevindt zich alan de mediale zijde van de calcaneus. (juist)

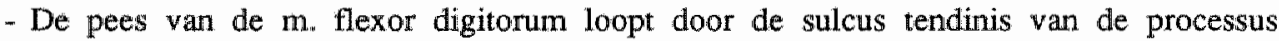
posterior van de talus en buigt dan aan de onderzijde van het sustentaculum naar voren om. (juist)

\section{Probleem 15}

Opdracht: Geef aan waarop $\mathrm{u}$ de volgende onderzoekshandeling wilt richten in het kader van de diagnosestelling.

Een bouwvakker van 29 jaar klaagt over een pijnlijke linkerknie. De knie is het pijnlijkst aan het eind van de werkdag. Met name traplopen veroorzaakt dan een felle stekende pijn aan de mediale zijde van de knie. De knie kraakt dan ook meer. 's Ochtends is de knie stijf en pijnljk. Maar dit gaat door bewegen snel over. De knie is nooit gezwollen. Volgens de patiënt is er nooit van een trauma sprake geweest. Er zijn geen röntgenfoto's gemaakt. Bij inspectie in stand staat de linkerpatella iets hoger dan de rechter. Er is geen atrofie. Stand knieën g.b.

Functie-onderzoek:

- Actief bewegen: g.b.

- Passief bewegen: flexie pijnlijk mediale zijde linkerknie bij testen eindgevoel.

- Weerstandstesten: vanuit de anatomische o-stand negatief. Wordt de knie vanuit maximale flexie tegen weerstand gestrekt dan wordt er stekende pijn aangegeven aan de mediale bovenpool van de patella. Kracht is goed.

- Spierlengtetesten: links is de $\mathrm{m}$. iliopsoas en de $\mathrm{m}$. rectus femoris verkort.

- Stabilitêitsonderzoek: g.b. 
- Palpatie: tonus mm. quadriceps links gelijk aan recht. Insertiepees caput mediale aan patella is dikker en drukgevoeliger dan rechts.

- Mobiliteit-patella: translatiemogelijkheid naar mediaal is links minder dan rechts.

\section{Kennisitems}

- Bij een chondromalacia patellae is vooral het traplopen pijnlijk omdat door een verhoogde tonus van de $\mathrm{m}$. quadriceps de patellofemorale kompressie toeneemt. (onjuist)

- Wanneer men twijfelt aan de diagnose chondromalacia patellae kunnen kompressietesten definitief uitsluitsel geven. (onjuist) 


\section{CURRICULUM VITAE}

De auteur Frans Ronteltap werd geboren in Haarlem op 28 juni 1948. Na het afsluiten van de ULO studeerde hij aan de Rijkskweekschool te Hengelo waarna hij in 1972 deze studie afsloot met het behalen van het diploma "volledig bevoegd onderwijzer". Vanaf 1972 studeerde hij Pedagogiek (afstudeerrichting Onderwijskunde) aan de Faculteit Sociale Wetenschappen van de Rijksuniversiteit Groningen tot augustus 1979 toen het doctoraalexamen werd afgelegd. Tijdens zijn studie Onderwijskunde was hij assistent bij de secties Didaxologie en Methodologie van genoemde afstudeerrichting en remedial teacher op diverse basisscholen in de gemeente Haren. In maart 1979 werd hij aangesteld als wetenschappelijk ambtenaar bij de vakgroep Onderwijsontwikkeling en Onderwijsresearch van de Rijksuniversiteit Limburg. In deze vakgroep heeft hij verschillende functies gehad. Eerst werd een onderzoek uitgevoerd naar de samenwerkingsmogelijkheden tussen HBO- en WO-opleidingen in de gezondheidszorgsector ten behoeve van de Coördinatiecommissie Gezondheidszorgopleidingen, in 1981 werd zijn aanstelling gewijzigd in universitair docent bij de Eerstegraads Lerarenopleidingen Gezondheidszorg van de Faculteit Gezondheidswetenschappen.

Laatstgenoemde aanstelling is nog steeds van kracht hoewel hij vanaf oktober 1987 is gedetacheerd bij de Faculteit der Geneeskunde als projectleider van het project Computerondersteund Onderwijs. 